DOE/ET/27112--2

DE83 014977

NOTICE PORTIONS OF THIS REPORT ARE ILLEGIBLE. It has been reproduced from the best available copy to permit the broadest possible availability.

Fronts

$\$$

1 November 1980 - 31 October 1981

CONSOLIDATED RESEARCH PROGRAM

inte UNITED STATES GULF COAST

GEOPRESSURED-GEOTHERMAL PROGRAM $\odot{ }_{\odot}{ }^{3} y$

\author{
ANNUAL REPORT, \\ for the Period
}

Myron H. Dorfman -

Robert A. Morton -

Henry F. Dunlap

David 0. Frederick -

Kenneth E. Gray -

Ekwere J. Peters

Kamy Sepehrnoori

Thomas W. Thompson

NOTICE

PORTIOHS OF THIS REPORT ABE ILLEGIBLE.

JuTy 1982

It has been reproduced from the best avaliable copy to permit the broadest possible avallabllity. un oNLX

Center for Energy Studies and Bureau of Economic Geology

$$
120^{300^{\circ}} \text { The University of Texas at Austin }
$$

Prepared for the
U.S. Department of Energy
Division of Energy Technology
Under Contract DE AC 08-79 ET 27112 


\section{DISCLAIMER}

This report was prepared as an account of work sponsored by an agency of the United States Government. Neither the United States Government nor any agency Thereof, nor any of their employees, makes any warranty, express or implied, or assumes any legal liability or responsibility for the accuracy, completeness, or usefulness of any information, apparatus, product, or process disclosed, or represents that its use would not infringe privately owned rights. Reference herein to any specific commercial product, process, or service by trade name, trademark, manufacturer, or otherwise does not necessarily constitute or imply its endorsement, recommendation, or favoring by the United States Government or any agency thereof. The views and opinions of authors expressed herein do not necessarily state or reflect those of the United States Government or any agency thereof. 


\section{DISCLAIMER}

Portions of this document may be illegible in electronic image products. Images are produced from the best available original document. 
This report was prepared as an account of work sponsored by the United States Government. Neither the United States nor the United States Department of Energy, nor any of their employees, makes any warranty, express or implied, or assumes any legal liability or responsibility for the accuracy, completeness, or usefulness of any information, apparatus, product, or process disclosed, or represents that its use would not infringe privately owned rights. Reference herein to any specific commercial product, process, or service by trade name, mark, manufacturer, or otherwise, does not necessarily constitute or imply its endorsement, recommendation, or favoring by the United States Government or any aqency thereof. The views and opinions of authors expressed herein do not necessarily state or reflect those of the United States Government or any agency thereof. 
TABLE OF CONTENTS

Page

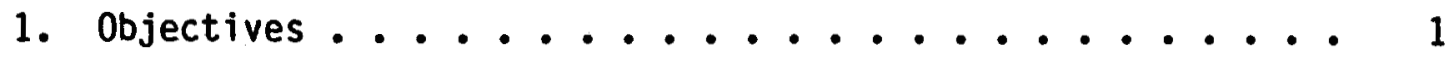

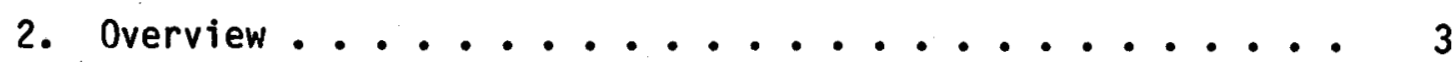

3. Coordination Assistance. ............. 5

4. Compaction Measurements on Texas Gulf Coast Sandstones

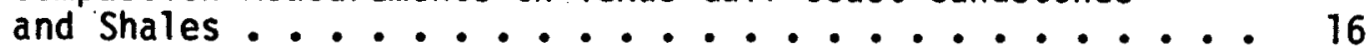

5. U.S. Gulf Coast Geopressured-Geothermal Aquifer

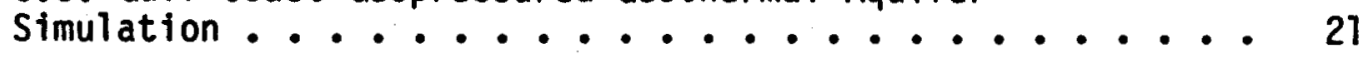

6. Preliminary Review of Subsidence Insurance Issues. ..... 28

7. Geopressured-Geothermal Information System ....... 35

8. Study of Log Derived Water Resistivity Values in Geopressured Geothermal Formations ......... 45 


\section{OBJECTIVES}

Task 1) The Center for Energy Studies (CES) and Bureau of Economic Geology (BEG) at The University of Texas at Austin (UT) will provide speakers for interested organizations within the state of Texas and present papers at national and local meetings and industrial workshops on topics concerning the development and research into geopressured-geothermal resources.

Task 2) The Center for Energy Studies has an established Board of Advisors to maintain rapport with industrial groups, state and local governmental agencies, and research participants. These people will meet periodically, and receive monthly reports of progress in all geopressured-related activities from the CES.

Task 3) CES and BEG personnel will coordinate with the Wells of Opportunity and Design Well contractors and sub-contractors, and will make recommendations involving well design, logging, completion procedures, and any matters related to field developments.

Task 4) CES personnel will provide analysis of data from all wells, including well log data, transient pressure analysis, compaction and creep studies of cores, and other related research.

Task 5) CES personnel will provide a preliminary review of subsidence insurance issues that may pertain to geopressured-geotherma 1 development in coastar zones in Texas.

Task 6) CES personnel will continue and maintain a GeopressuredGeothermal Information System, including updates of thesaurus and bibliography of all geopressured-related papers and 
abstracts on computer data files. Developments will continue of $\log$ digitizing techniques as well as of digitization of new well logs for statistical and graphic presentation for use in devlopment of various $x$-plots for optimization of drilling, and for estimates of temperature and pressure vs. depth, temperature mapping of various data, etc.

Task 7) Special studies of log data and evaluation will be carried out by H. F. Dunlap and others in an effort to correct sources of extreme error in well log evaluation of water resistivities and arrive at better estimates for future evaluation. 


\section{OVERVIEW}

During the contract period, Task 1 , as shown in the preceding section is reported in detail on a monthly basis in the ensuing section. In addition to those meetings formally reported, many informal meetings with various governmental officials and others were held concerning future funding needs of the program, and priorities were discussed at some length with the Department of Energy and the Office of Management and Budget. The assistance of legislators of the State of Texas and members of the Texas Railroad Commission was instrumental in assisting CES and BEG coordinators in these meetings.

Task 2 consisted primarily of monthly reports to the Board of Advisors, which are not included in this document, due to the extreme length of these reports. They are on file with the Department of Energy, Division of Geothermal Energy, and have been cited extensively in the literature in ensuing papers by various research entitites outside of The University of Texas at Austin. These reports go to approximately 150 units in addition to the Board of Advisors. The Board of Advisors held one formal meeting during the contract period to review progress in geopressured-geothermal research.

Task 3, coordination with contractors and sub-contractors on wells, is not reported in detail herein, since many of these activities were conducted on an ad-hoc basis, either by telephone or in informal meetings. For example, analysis of well logs on the Gladys McCall well were conducted by Dr. Dorfman informally during the Fifth GeopressuredGeothermal Conference in Baton Rouge upon completion of the logging runs. Recommendations were made for additional dipmeter data requiring 
an additional logging run on this well. This proved to be of great value in ascertaining the correct correlation of the well with regard to the major fault in the field. Similar activities were conducted each month during the contract period. In addition, ad hoc meetings with DOE field personnel, IGT investigators and others were held in Houston on such matters as perforation intervals on wells and potential stimulation techniques.

Tasks 4, 5, 6, and 7 are herein reported in some detail. It. should be noted that the work in Task 7 has proven to be of great interest to industry and has resulted in a major paper included in the Transactions of the Geothermal Resources Counci1, 1981. 
3. COORDINATION ASSISTANCE - November 1980 - October 1981

November 1980 Discussed study of formation water salinity with industry representatives at meeting of American Association of Petroleum Geologists research subcommittee, Houston, Texas. (Robert A. Morton)

Organized symposium on Gulf Coast geopressuredgeothermal research for South Central Section meeting of the Geological Society of America, April 1981. (Robert A. Morton)

Sent map of Blessing Prospect to Oak Ridge National Laboratory for environmental analysis and site inspection.

Discussed DOE geothermal program with Mr. Prapath Premmani, Deputy Secretary General of the National Energy Administration of Thailand.

Sent copy of Sandstone II final contract report to Mr. Dimitri Sverjensky, Lawrence Berkeley Laboratory.

December 1980 Attended SEPM Research Conference on Geology of the Woodbine--Tuscaloosa Formation. (Robert A. Morton) Discussed with Jim Clements (Houston), geothermal prospects for possible use in ethanol production. 
Reviewed manuscript entitled "Water Quality Impacts Associated with Offshore Disposal of Geopressured Brines" for the American Association of Petroleum Geologists Bulletin.

Presented test results at the Geothermal Resources

Committee meeting of the Interstate $0 i 1$ Compact

Commission, Santa Fe, New Mexico. (Myron Dorfman)

January 1981 Text from GRI report describing geology of Blessing

Prospect sent to Technadril per their request.

Sent structure map and cross-section of Miocene interval, Brazoria area, to C. K. GeoEnergy for injection study.

Met with representatives from Oak Ridge National Laboratory and Technadril to discuss geology and environmental assessment of Blessing Prospect.

Reviewed core handling procedure developed for Western sands program and made recommendations for revision of draft standard procedures for design well program.

Provided DOE with application documewnts for proposed Enhanced Gas Recovery project, North Alazan Field, Kleberg Co., Texas. 
Reviewed Geopressured-Geothermal program with DOE officials in Austin.

Reviewed Geopressured-Geothermal program with National Science Foundation officials, Washington, D.C. (Myron Dorfman)

Discussed Blessing leases with Hank Coffer, C-K GeoEnergy.

Sent copies of South. Texas cross sections from methane project to Magma Gulf Corporation.

Reviewed and commented on C-K Petroleum \#1 Godchaux, Vermilion Parish Louisiana as possible well of opportunity. Evaluated salinity calculations and revised recommendation.

Discussed Pleasant Bayou geology and environmental monitoring with Bob Sterret, Lawrence Berkeley Laboratory. Provided copies of core analyses, unpublished maps and cross-sections in Austin Bayou Prospect area.

February 1981 Discussed status of geopressured-geothermal program with Dick Need, Ames Oil Company, Houston. Assisted B 111 Hockenbrock in defining tracts of primary interest for leasing purposes (Blessing Prospect). 
Provided Wayne Wood, independent in San Antonio, with bottom hole temperature information for Pleasant Bayou no. 2.

Responded to request from Los Alamos Laboratory for thermal gradient information.

Provided DOE with sample salinity calculation for "A" sandstone in the $C$ and $K$ Petroleum Frank $A$. Godchaux well, Live Oak Field, Louisiana.

Sent copies of e-logs from Pleasant Bayou no. 2 to Don Bebout for calibration of salinity calculations.

Provided landowner with information regarding geopressured-geothermal potential near Powderhorn Lake, Matagorda County, Texas (request through Petroleum Engineering).

Provided John Oddo, Rice University, with a copy of sandstone consolidation report for Pleasant Bayou no. 2 (Fourth Geopressured-Geothermal Conference) as part of his scaling and corrosion study.

Talked to Society of Petroleum Engineers chapter in Houston on Geopressured-Geothermal Energy. (Myron Dorfman) 
March 1981 Reviewed and commented on CK GeoEnergy draft report entitled "Geopressure-Geothermal Reservoir Continuity-Louisiana and Texas Gulf Coast."

Attended meeting of program review committee for the Fifth Geopressured-Geothermal Energy Conference. (Robert Morton)

Presented a talk on status of the geothermal program at the monthly meeting of the Corpus Christi Geological Society. (Robert Morton)

Sent copies of rock mechanics reports for Fourth Geopressured-Geothermal Energy Conference to R. C. Wilshusen, Corpus Christi, Texas.

Sent copy of Wilcox geopressure-geothermal resource study to Warren Horowitz, Phillips Petroleum Company, Houston, Texas.

Reviewed report to EPRI prepared by Southwest Research and responded to an article published in the 011 and Gas Journa1. (Robert Morton and Myron Dorfman)

Participated in a DOE-sponsored meeting on salinities calculated from electric logs and provided sample calculations for specific wells. (Robert Morton and Ray Gregory) 
Convened and participated in technical session on Gulf Coast geopressured energy resources. (Robert Morton) Meeting was sponsored by the south central section of the Geological Society of America. The following papers were presented:

R. A. Morton - Factors critical to the development of energy resources from geopressured aquifers in Texas.

T. E. Ewing and R. A. Morton - Reservoir Continuity and Gulf Coast geopressured resources.

W. R. Kaiser, K. Magara, K. L. Milliken, D. L. Richmann - Petrography, water-rock interaction, and caprock distribution as potential indicators of secondary porosity in the Frio Formation of Texas.

Reviewed and commented on McMoRan A. J. Maier no. 2, Plaquemines Parish, Loutsiana, as a possible well of opportunity.

Provided Syed A. Ali, Gulf Research and Development, with a copy of Sandstone Consolidation contract report.

Provided Gene Scott, Ensearch (Dallas), access to Vicksburg cross-sections and maps.

Provided Gary Kinsland, University of Southwest Louisiana, with a copy of industry contract and 
shooting array for seismic data acquisistion in Cuero area.

Reviewed and commented on Houston $0 i 1$ and Mineral R. H. Clarke et al. no. 1, Matagorda County, Texas as possible well of opportunity.

Reviewed Geopressured-Geothermal with Gearhart Industries, Ft. Worth. (Myron Dorfman)

May 1981

Discussed offshore geopressure-geothermal potential with Larry Green, McDermott Engineering, New Orleans, Louistana.

Discussed status of geopressured-geothermal program with representatives of Radian Corporation, Austin, Texas.

Served on TENRAC Geothermal committee to set priorities for state funding. (Myron Dorfman)

Discussed geopressured-geothermal program and DOE budget reductions with Congressman Hamilton Fish of New York.

Attended CK GeoEnergy meeting to review program status and present results of logging research and rock mechanics. (Morton, Dorfman, Dunlap) 
Provided George Moncure, Conoco Research, with copies of Sandstone II final contract report and Sandstone III interim technical report and access to Pleasant Bayou 1 and 2 cores.

Visited Assistant Secretary of Energy Joseph Tribble. and Gary Benethum of the Office of Management and Budget, Washington, D.C. (Myron Dorfman)

Attended C.K. GeoEnergy meeting in Houston and presented updated information on design-well prospects in Texas. (Robert Morton)

Discussed geopressured-geothermal logging with S. Kelsey, Sandia Labs. (Myron Dorfman)

Met with Central Power and Light to discuss program status. (Myron Dorfman)

Discussed prospect potential of Point Comfort area with Leo Rogers, CK GeoEnergy.

Spoke at UT Energy Symposium on GeopressuredGeothermal Energy. (Myron Dorfman)

Provided Technadril-Fenix and Scisson with anticipated depths, pressures, and temperatures for objective sands In the Blessing area and a copy of the Blessing Prospectus. 
Reviewed geopressured-geothermal logging at Louisiana State University. (Myron Dorfman)

Reviewed and commented on Border Exploration \#1 Beard (Wilcox) Wharton County, Texas, as possible well of opportunity.

Discussed future funding with Keith Westhusing and Bob Holliday, DOE. (Myron Dorfman)

Discussed with Gary Kinsland, Southwestern Louisiana, the contract between The University of Texas and the geophysical company used to acquire seismic data.

August 1981

Discussed DOE geopressured-geothermal research program in Texas with Gas Research Institute Board of Advisors on unconventional gas.

Evaluated ways of obtaining micropaleontological data for Pleasant Bayou no. 1 and no. 2 for possible paleonenvironmental interpretation, to be used as a cross check with regional e-log and seismic interpretation as well as core interpretation.

Met with Dr. Walter Fert1, Vice-President of Dresser At las, on geopressured-geothermal logging research. (Myron Dorfman) 
Discussed sk in factor of rocks in geopressuredqeothermal gas wells with Texas $0 i 1$ and Gas.

Discussed future funding of geopressured-geothermal in U.S. House Science and Technology Committee-Representative Fuqua, Chairman. (Myron Dorfman)

September 1981 Sent copy of "Wilcox sandstone reservoirs in the deep subsurface along the Texas Gulf Coast, thin potential for production of geopressured-geothermal energy" to R. M. Condon, Tex-Tech Energy, Houston.

Provided Clarence Albers (Amoco, Houston) with 33 selected shale samples from Pleasant Bayou no. 1 and no. 2 cores for micropaleontological analysis including paleobathymetry and possibly environment of deposition.

Presented talk entitled "Methane entrained in Gulf Coast geopressured aquifers" at monthly meeting of the Houston Geological Society, Houston, Texas. (Robert Morton)

Invited to write "Distinguished Author" paper on geopressured geothermal energy for Journal of Petroleum Technology of SPE. (Myron Dorfman) 
October 1981 Received a summary of foraminifera species in the shales from Pleasant Bayou No. 1 and No. 2 cores and the interpreted paleoenvironments. The micro paleontologic zones agree closely with those interpreted from core descriptions for the reservoir continuity study.

Reviewed and evaluated the Arco 011 and Gas \#1 Fuqua Industries well in Ft. Bend County, Texas, as possible well of opportunity.

Chaired seminar at Fifth Geopressured-Geothermal Energy Conference, Louisiana State University, Baton Rouge, Louisiana, and presented paper with Henry Dunlap. (Myron Dorfman) Five Center for Energy Studies papers were presented.

Met with Houston Lighting and Power officials in Houston to discuss geopressured-geothermal program status. 
4. COMPACTION MEASUREMENTS ON TEXAS GULF COAST SANDSTONES AND SHALES Following is a summary of the work carried out during the past year on Contract ADE-AC08-79-ET-27112.

Creep Testing

Fourteen tests have been run on cores from the Pleasant Bayou wells, two under drained conditions, eight undrained, two combined drained and undrained, and two under conditions of pore pressure drawdown. Horizons have ranged from 10251 feet to 14760 feet and times for creep deformation up to 124 days (Table 1). All of these tests have been run under varying loads to investigate history dependence. High temperature tests have not been run. These tests are awaiting the completion of non-time dependent testing in the high temperature rig. Petrographic analyses have been performed on most of these test cores and are reported by Richardson (M.S. Thesis, University of Texas, 1981). Preliminary analyses of data show that the cores show considerable specimen to specimen variation, indicative of formation heterogeneity. History dependence appears to be controlled by a strain hardening mechanism and models based on this are being formulated.

\section{High Temperature Testing}

Development of a high-temperature Simultaneous Property System has proceeded with substantial difficulty, owing to the complete redesign and construction of internal components of the rock sample containment and measuring system. Checkout runs on Berea sandstone samples to $400^{\circ} \mathrm{F}$ have been completed. Data are being analyzed to ensure proper operation 


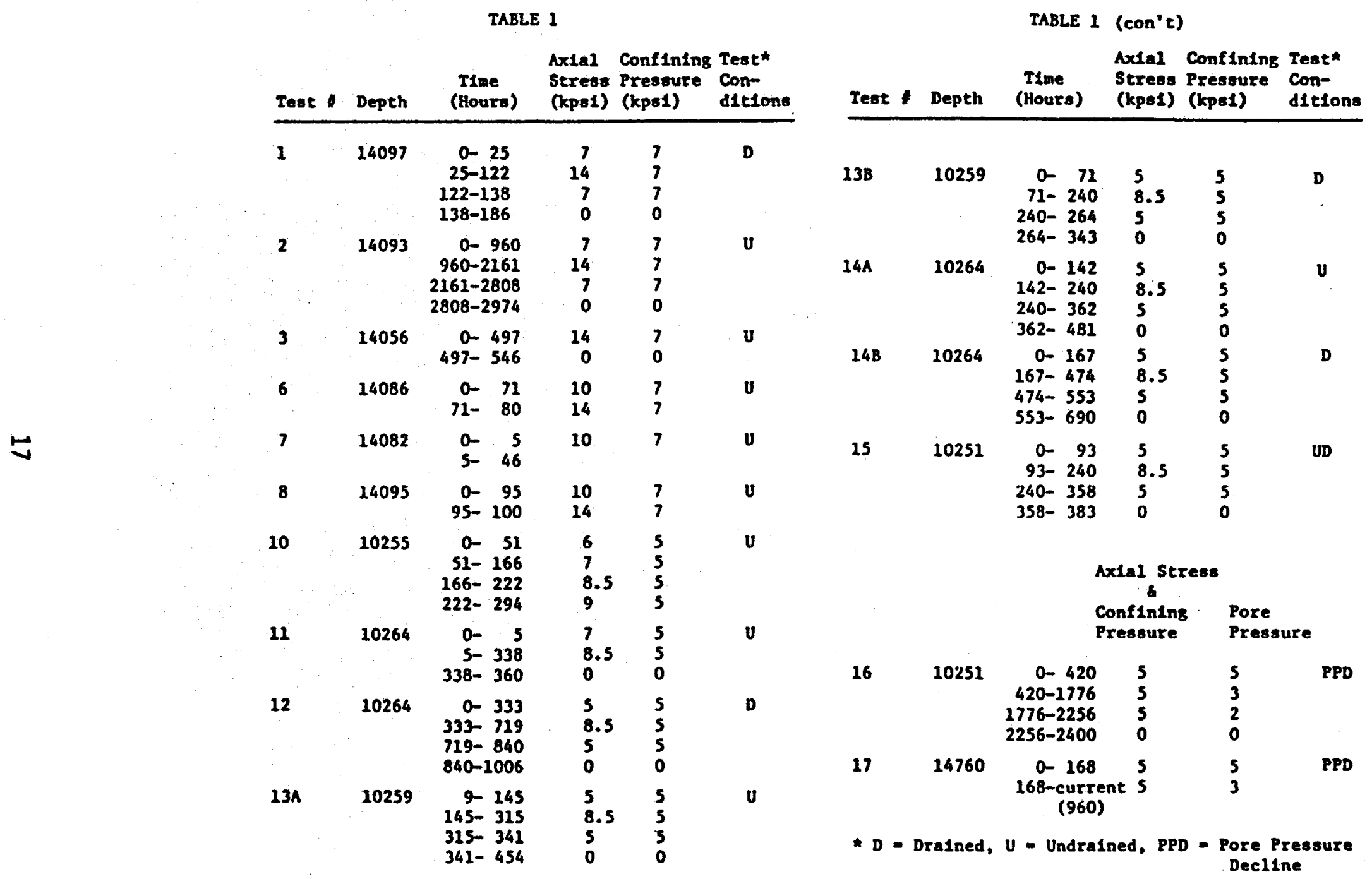


of all components of the system prior to testing Brazoria County cores under various loading paths and elevated temperatures.

Room Temperature Setting

Additional compaction tests on Pleasant Bayou cores have been completed, using the Simultaneous Property System. The results are summarized in Table 2.

The results indicate that reservoir drive from compaction due to pore pressure reduction is non-linear; it will be high initially but will diminish rather rapidly as pore pressure is reduced. Some general observations from the experimental results are:

1. Bulk compressibilites show a decrease of $55-65 \%$ as effective axial stress is increased to its maximum value.

2. Bulk compressibilities at atmospheric pore pressure are higher than the values obtained at elevated pore pressures for the same level of effective stresses. This show that matrix compressibilities are not insignificant as is often assumed.

3. Uniaxial compaction coeffictent, $C_{m}$, range similarly as bulk compressibility values. At the same effective stress level, $c_{m}$ is approximately $1 / 2$ of bulk compressibility.

4. $C_{m}$ values obtained over the same effective axial stress range (approximately 7500 psi) but at lower levels of overburden stress (7500 to $15000 \mathrm{psi}$ ) and pore pressure (0 to $7500 \mathrm{psi}$ ) were significantly higher than $C_{m}$ values obtained at overburden stress of 15,000 psi pore pressure varying from $15,000-7500 \mathrm{psi}$. This is due to the higher 
TABLE 2

Reservolr Rock Parameters, GCO-DOE 11 \& 12

\begin{tabular}{|c|c|c|c|c|c|c|c|c|}
\hline & & \multicolumn{2}{|c|}{$\begin{array}{l}\text { Bulk Compress1b111ty*k } \\
\left(\times 10^{-6} \mathrm{ps1}^{-1}\right)\end{array}$} & \multicolumn{5}{|c|}{ Unlaxxlal Compaction Test*k } \\
\hline \multicolumn{2}{|c|}{$\begin{array}{l}\text { Seress } \\
\text { Level }\end{array}$} & $\begin{array}{l}\text { Peconstant } \\
\text { P }_{p}^{\text {evarles }}\end{array}$ & $\begin{array}{l}P_{c}=0 \\
P_{p}=0\end{array}$ & $\left(x 10^{C}\left(\mathrm{ps}^{-1}\right)\right.$ & $\phi(z)$ & \multicolumn{2}{|c|}{$k(n d)$} & $\mathbf{E}$ \\
\hline \multicolumn{2}{|l|}{ CCO-DOE 1} & & & & & & & \\
\hline $1-4-11755 t$ & $\begin{array}{l}\mathbf{L} \\
\mathbf{L}\end{array}$ & $\begin{array}{l}1.4-.71 \\
2.0-.84\end{array}$ & $2.4-.87$ & $\begin{array}{l}1.22-.45 \\
1.17-.43\end{array}$ & $\begin{array}{l}19.65-19.13 \\
19.31-18.94\end{array}$ & $\begin{array}{l}20.5 \\
11.5\end{array}$ & $\begin{array}{l}-15.5 \\
-11.0\end{array}$ & $\begin{array}{l}21.1-25.2 \\
23.9-27.52\end{array}$ \\
\hline $\begin{array}{r}1-7-14751 \\
14765 \\
\text { CCO-DOE } 2\end{array}$ & $\mathbf{L}$ & $.78-.43$ & & $\begin{array}{l}.64-.21 \\
.40-.23\end{array}$ & $\begin{array}{l}29.31-18.99 \\
17.63-17.34\end{array}$ & $\begin{array}{l}86 \\
69\end{array}$ & $\begin{array}{l}-70 \\
-62\end{array}$ & $\begin{array}{l}23.0-25.31 \\
16.99-21.13\end{array}$ \\
\hline $\begin{array}{r}2-1-14696 \\
14696 \\
14699 \\
14702+ \\
14703 \\
14711 t \\
14712\end{array}$ & 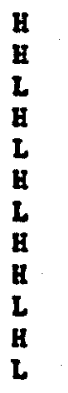 & $\begin{array}{r}1.0-.48 \\
1.1-.50 \\
.88-.41 \\
1.1=.44 \\
1.3-.48 \\
2.1=.32 \\
1.4=.61 \\
1.4=.45 \\
1.6-.50 \\
1.95-.52\end{array}$ & $\begin{array}{l}1.30-.71 \\
1.73-.81 \\
1.35-.73 \\
1.33-.76\end{array}$ & $\begin{array}{l}.60-.21 \\
.87-.29 \\
.67-.29 \\
.42-.29 \\
.60-.22 \\
.73-.29 \\
.90=.32 \\
.84-.31 \\
.52-.23 \\
.57-.23 \\
.84=.29 \\
.47-.235\end{array}$ & $\begin{array}{l}18.23-17.89 \\
17.18-16.93 \\
17.18-16.30 \\
16.77-16.38 \\
16.77-16.27 \\
19.52-19.17 \\
19.47-19.06 \\
16.95-16.77 \\
21.16-20.90 \\
21.2-20.78 \\
19.16-19.02 \\
19.16-18.94\end{array}$ & $\begin{array}{l}92 \\
7.2 \\
7.4 \\
91 \\
215 \\
25.5 \\
25.5 \\
26.8 \\
168 \\
144 \\
26 \\
38.5\end{array}$ & $\begin{array}{l}-83 \\
=4.2 \\
=5.2 \\
=87 \\
=94 \\
=23.4 \\
=17.2 \\
=19.5 \\
-155 \\
-121 \\
=19 \\
=35\end{array}$ & $\begin{array}{l}26.25-30.46 \\
27.6-32.35 \\
22.15-27.76 \\
22.9-26.74 \\
21.3-26.45 \\
23.75-27.40 \\
24.6-28.25 \\
24.10-28.15 \\
18.1-19.25 \\
16.7-28.5 \\
23.3-25.80 \\
23.55-25.80\end{array}$ \\
\hline $\begin{array}{c}2-3-15665 t \\
15668\end{array}$ & $\begin{array}{l}\mathbf{L} \\
\text { H } \\
\text { L }\end{array}$ & $\begin{array}{l}1.1-.53 \\
.83-.37 \\
1.0-.41\end{array}$ & $1.3-.68$ & $\begin{array}{l}.80-.30 \\
.48-.19 \\
.99-.29\end{array}$ & $\begin{array}{l}19.68-19.25 \\
19.82-19.58 \\
19.75-19.27\end{array}$ & $\begin{array}{l}79 \\
69 \\
68\end{array}$ & $\begin{array}{l}-66.5 \\
-51.5 \\
-36.5\end{array}$ & $\begin{array}{l}21.25-23.63 \\
25.5=29.25 \\
26.3-30.2\end{array}$ \\
\hline
\end{tabular}

- H - Corresponds to the Initial stress condition on the specimen. $p_{-}=p_{c}=p_{p}=s p e c 1 m e n$ depth

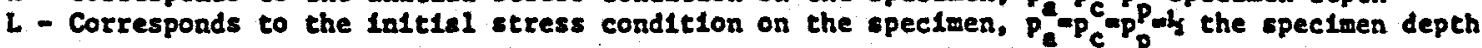

+ Measured matrix compressibllities varies trom 0.31 to $0.33 \times 10^{-6} \mathrm{psi}^{-1}$.

** Range shown as effective stress increases from low to high values 
values of confining pressure requried to keep lateral deformation zero at the higher stress levels involved in these tests.

5. Porosity reductions are lower than corresponding permeability reductions which suggests that preferential closure of flow channels/cracks takes place as a result of compaction.

6. Resistivity increase and consequently the increase in formation factor follows the same trend as porosity reductions.

7. The effective stress law applies well in terms of trends in rock parameters with pressure. However, the numerical values for those parameters depend upon the stress levels involved in achieving a particular value of effective stress.

Modelling and Simulation

Three modelling efforts have been carried out simultaneously

- A numerical simulator has been developed based on the nucleus of strain solution extended to linear viscoelasticity. This simulator includes a finite element formulation for the reservoir performance.

- An existing finite element code has been extended to allow piece-wise linear viscoelastic rock response.

- A reservoir simulator has been extended to include linear viscoelastic rock response. 


\section{U.S. GULF COAST GEOPRESSURED-GEOTHERMAL AQUIFER SIMULATION}

The work described herein was performed for the Department of Energy's Geopressured-Geothermal Division under contract with The University of Texas at Austin. The purpose of this work is to develop methods for analyzing geothermal-geopressured reservoir production behavior and to predict such behavior in the future given specific exploitation scenarios.

This report summarizes work accomplished during the fifth year of this effort.

\section{GENERAL PURPOSE RESERVOIR SIMULATOR}

At the Center for Energy Studies of The University of Texas at Austin, the reservoir simulation has been successfully conducted to assess the reservoir performance of geopressured aquifers by using an isothermal, two-phase, two-dimensional model. Paralleling the work at UT, Systems, Science and Software $\left(S^{3}\right)$ performed the modeling of geopressured-geothermal reservoirs for UT under the subcontract. On the expiration of the subcontract, UT acquired the $s^{3}$ model.

The early studies of geopressured-geothermal reservoirs predicted low recoveries and possible ground subsidence and indicated the need of expanding the reservotr study to include cold-water injection cases. The isothermal model developed at UT, however, was found inadequate to modify to handle the complex phenomena assoclated with the cold water injection, for the model was coded for the spectfic purpose of black-oil type simulations. Meanwhile, the great difficulties were encountered in the implementing the $s^{3}$ model at UT mainly because of the differences of 
the FORTRAN languages at the two institutes. Under this circumstance the decision was made to develop a general purpose reservoir simulator.

\section{Applicable Problems}

In writing the programs the problem type was restricted to time-dependent, coupled convection-diffusion equations. Furthermore, the approximation method was assumed to be finite differences. The main features of problems to which the general purpose reservoir simulator is applicable are summarized below.

1. The problem must be described by a system of up to five coupled partial differential equations (PDE). The problem can be linear or nonlinear. Some PDE's may be time-independent but the system of PDE's as a whole is assumed to describe time-dependent phenomena.

2. The space domain can be one, two, or three-dimensional and can be deformable in the vertical direction. The coordinate system can be a Cartesian, 1-D radial, or 2-D cylindrical $(r-z)$. The threedimensional models are practically impossible to run at UT because of the small central memory allowed for each user (376K octal).

3. The temporal integration of PDE's is presently limited to the backward difference. To solve nonlinear difference equations, four iterative techniques are available; the Newton method, modified Newton method, semi-implicit method, and simple substitution method.

4. The system of linear equations resulting for each nonlinear iteration is solved by one of the three methods; the LU decomposition, 
the Gaussian elimination with economized storage, and the line successive over-relaxation method.

Program Structure

The entire process of reservoir simulation was broken down into several modules. These modules were then categorized into two classes, problem-independent and problem-dependent.

The problem-independent routines should be applicable to various problems without significant changes. These routines are referred to as general routines below. They include the following:

1. Preprocessing such as determination of data structure

2. Input/output

3. Grid definition

4. Time-marching, i.e., construction and solution of linear equation systems, iteration for convergence and advancing time steps The problem-dependent routines are primarily those that calculate PDE coefficients and other informative variables. They are stereotyped as follows:

1. Initialization

2. Update secondary dependent variables

3. Storage term calculation

4. Diffusion term calculation

5. Convection term calculation

6. Point/line source calculation

7. Other source term calculation

8. Boundary condition calculation 


\section{Informative variable calculation}

The general routines call only these nine problem-dependent subroutines besides the communication among the general routines themselves. Since the central memory size is very limited at UT, the programs were designed so that unused data storage spaces would be minimized. Almost all variables were put in a single common block. In the general routines this common block is represented by a single generic array variable. The preprocessing mentioned above includes the partition of this generic array and setting address pointers of actual variables based on the variable information (type, size, etc.) given by input. The address pointers for arguments of the problem-dependent subroutines are also determined during the preprocessing. The general routines call the problem-dependent subroutines using the generic array with pointers set during the preprocess as arguments. The problemdependent routines will have realistic variable names for their formal parameters so that these programs are readable.

The compiled binary general routiens are stored on a permanent file. Currently, the user needs to read necessary general routines from the permanent file, combine them with the problem-dependent routines to form a complete program and load it to the central memory. A more systematic and easier procedure to run the program would be desirable in the future.

The cold-water injection project is proceeding with the single phase assumption. The problem-dependent routines were written based on this assumption and are being tested. Should the assumption prove to be inappropriate, the system of governing differential equations must be 
replaced by a more complex, multi-phase problem, and the problemdependent routines would need to be accordingly rewritten. However, the general routines would not require any modification.

Besides the simulation programs, the decent plot capability has been also established. The output routines of the simulator create files which are compatible with the plot programs. That is, the output files written during a simulation are fed as input files to the plot programs. The plot programs use the NCAR (National Center for Atmospheric Research) graphic routines to generate history curves, contour, and vector plots.

\section{RESERVOIR PERFORMANCE IN VISCOELASTIC POROUS MEDIA}

The mass balance equations for a two-phase two-component fluid system are written for viscoelastic porous media. The resulting equations are approximated by finite differences and the resulting numerical simulator is used to conduct a sensitivity study on the effects of uniaxial viscoelastic deformation in geopressured aquifers. Results of this study indicate that viscoelastic deformation may have considerable influence on the pressure maintenance of these aquifers. A numerical model of the geopressured aquifer in Brazoria county, Texas is constructed and the numerical simulator is used to predict the ultimate recovery of solution gas from this viscoelastic geopressured aquifer.

In the case of the viscoelastic reservoir (at 40,000 STBW/day pro-. duction rate) the 1 ife of the well approaches ten years, whereas for the elastic reservotr the life of the well is about seven years. These results indicate $40 \%$ improvement for the well life over the elastic. 
reservoir. In addition, after five years of production, the viscoelastic reservoir indicates that water recoveries will be $1.98 \%$ of the initial water in place resulting in a per well recovery of $1.83 \%$ of the initial gas in place. These compare to a $1.5 \%$ recovery for the purely elastic reservoir.

PRELIMINARY TEST RESULTS OF THE FIRST GEOPRESSURED-GEOTHERMAL DESIGN WELL, BRAZORIA COUNTY, TEXAS

The Pleasant Bayou \#2 geopressured-geothermal test we1l was completed in the summer of 1979. The $C$ sand of the Frio formation was selected for completion on the basis of core analysis, well logs, and drillstem tests. The purpose of this section is to summarize the results of the short term production tests run on the Pleasant Bayou \#2 well during 1979 and the Fall of 1980. These tests were analyzed using conventional transient pressure test analysis methods.

The most significant test run during 1979 was a ten day drawdown test from December 3 to December 14 followed by a 20 day buildup period, during which reservoir pressure response was observed. After a hiatus of nine months, a second production test was conducted over a period of 45 days beginning on September 16, 1980. The well was shut in on October $31,1980$.

Both production tests indicate a formation permeability of 200 milli-darcies. The presence of a permeabflity interruption located approximately 3700 feet from the well bore is also suggested by these tests. 
During the last production test, a producing gas-water ratio of 20 standard cubic feet per barrel of produced water was observed. An additional 9-12 standard cubic feet of gas per barrel was found in the water downstream of the separator. The total gas-water ratio of 29-32 SCF/bbl is in reasonable agreement with laboratory data and correlations for this produced brine.

The major growth fault which forms the reservoir boundary to the northwest of the well is evident from the pressure drawdown data obtained during the last production period. The last production test also indicates an apparent rate dependent skin effect. 


\section{PRELIMINARY REVIEW OF SUBSIDENCE INSURANCE ISSUES}

Overview

This review addresses the need of a geopressured-geothermal resource developer to secure liability insurance against damages arising to third parties because of surface subsidence caused by his or her pumping of geopressured brines. The review briefly describes the potential for large liabllity exposure which exists along the Gulf Coast, reviews Texas law (principally the Friendswood case) arguably pertinent to the liability of the geopressured resource developer, and arrives at the conclusion that the geopressured resource developer should turn to insurers who commonly work with the mining industry to secure insurance against subsidence-induced liability.

\section{Discussion}

The potential for surface subsidence caused by the pumping of geopressured brine from geopressured-geothermal reservoirs is obviously great. As Dr. Tom Gustavson, probably the leading Texas authority on the environmental consequences of geopressured-geothermal development, has often commented, a geopressured-geothermal development well producing 30,000 barrels of brine per day would, in the period of a year, withdraw from subsurface formations more brine than has been pumped from beneath the Texas Gulf Coast by conventional ofl and gas producers since the advent of the industry. Our understanding of the geophysical interactions between the reduction of reservoir pressure at depths beneath 15,000 feet and the subsidence of surface solls is not 
sufficient for confident prediction that deep, large volume brine production will necessarily cause surface subsidence.

The potential for economic liability because of subsidence induced by a geopressured-geothermal developer is great. Surface subsidence along the Texas Gulf Coast obviously exposes activities on that surface to greater risk of inundation by fresh water floods and salt water intrusions from the Gulf of Mexico. Further, surface subsidence can cause important misalignments of man-made structures such as highways, bridges, railroads, pipelines, and wells (011 and gas, fresh water, and waste disposal). Particularly in the case of pipelines and wells, even minor dislocations caused by surface subsidence can cause severe operational problems.

The principal Texas law on the liability of one who produces water from beneath the ground for surface subsidence caused by that production is the Texas supreme court case of Friendswood Development Company vs. Smith-Southwest Industries, 567 S.W. 2nd 21 (Texas 1978). In Friendswood, the defendant (Friendswood) began pumping massive amounts of ground water from beneath the Houston-Galveston region for sale to industrial customers. A group of landowners brought a class action suit alledging that the defendant's negligent extraction of ground water caused their land to sink and exposed it to erosion damage and flooding. The trial court threw out the landowners' suft, because the prevailing Texas law was that a landowner had the absolute right to produce ground water from his land without thereby exposing himself to liability, unless that pumping was willful waste or with intent to injure other parties. The landwoners appealed their case to the first level 
appellate court and that court ruled that the trial court should have not have thrown out the case because, if Friendswood's actions were negligent, "the fact that he owns the water produced will not insulate him from the consequences of this negligent conduct."

Following this ruling, Friendswood appealed to the Texas Supreme Court. The Supreme Court reversed the first level appellate court and said that the trial court had been correct after all. The Texas Supreme Court said, however, that the law which it was applying was harsh and outmoded. The court announced that in the future it would not apply this law, but would do as the first level appellate court had done.

The most important aspect of the Supreme Court's ruling in Friendswood was that, after 1978, the producer of ground water could be held liable for subsidence induced by his ground water production if he were negligent in the process of that production.

There are two reasons why a geopressured-geothermal developer might not be too concerned about the Friendswood ruling. First, a plaintiff suing under Friendswood would have to prove that the developer knew his production would cause the surface subsidence complained of. As mentioned earlier, our understanding of the interactions of forces between the geopressured-geothermal reservoir at 15,000 feet and the surface is not sufficiently well understood that a developer can be reasonably charged with foreseeing the consequences of his production of brine from the deep subsurface.

The second reason is that the Friendswood case deals with production of "ground water"; other cases and the Texas legislature commonly use the term "underground water" and "ground water" interchangeably. 
Either term is commonly interpreted to mean:

"water percolating below the surface of the earth and that is suitable for agricultural, gardening, domestic, or livestock raising purposes..." (Quoted from the Texas Water Code, Section 52.001, which sets forth the definition for terms for Texas' underground water conservation district law).

By no reasonable stretch of the imagination can our understanding of geopressured brine be said to include percolation form the surface or suitability for any of the activities outlined in the preceding quote. The characterization of geopressured brines as minerals, rather than ground water, would be more factually appropriate and would be consistant with the Texas legisiature's policy decision to treat geopressured-geothermal development as an activity under the jurisdiction of the Texas Railroad Commission rather than the Department of Water Resources.

Though a sound argument can be made that the production of brine by a geopressured-geothermal developer is not an activity which is covered by the Friendswood decision, there are other legal theories under which a developer could be held liable for surface subsidence. The theory which appears to be most applicable is that of "subjacent support". This theory holds that a landowner has a right to expect the support of his soll, both lateraliy and vertically. One who causes another's land to lose its support will be held strictly liable for the economic consequences of that loss of support. This latter ramification can be particularly important to a geopressured-geothermal developer because the determination of his or her liability would be in no way influenced by considerations of negligence; that is, the developer could be held 
liable whether or not the production of geopressured brine was conducted in a negligent manner.

The plaintiffs in the Friendswood case raised the subjacent support doctrine as one of the grounds on which they sought recovery. The Supreme Court said that theory did not apply to their case and gave two reasons. The first reason was that theory historically dealt with the removal of minerals and the court was unwilling to classify ground water as a mineral. As previously indicated, this reason would not appear to apply in the case of geopressured-geothermal brine production because that brine should not logically be considered ground water.

The court's second reason for rejecting the theory as one available to the plaintiffs in the Friendswood case was that the 1939 Restatement of Torts, the principal U.S. codification of the rules for assigning liability for damages of this nature, specifically stated that "to the extent that the person is not liable for withdrawing subterranean waters from the land of another, he is not liable for any subsidence of the other's land which is caused by that withdrawal." This language was deleted from the Restatement (Second) of Torts, which was published in 1979, after the date of the Friendswood decision.

Producer liability for production of geopressured-geothermal brine would appear to exist under the doctrine of subjacent support. Because this doctrine imposes strict llability on the individual or organization that removes a landowner's subjacent support, that individual or organtzation will not be able to avail itself of the defense that it did not know that the production on brine would cause the removal of subjacent support. The most practical consequence of this is that, as our 
understanding of the interactions between deep subsurface geophysics and surface subsidence improves, causes of subsidence which are not commonly acknowledged by authorities today may come to be so 15 years later, at which time land owners who suffered surface subsidence could sue the geopressured-geothermal producer for losses stretching back in time to the present.

In the absence of liability insurance a producer would be foolhardy to undertake development under these circumstances. There exists a body of insurance law and custom which has arisen because of more conventional mining activities, both in the United States and other common law jurisdictions (such as England). It is to insurance and statutory benefits accorded the mining industry that the geopressured-geothermal developer should turn to shield himself from liability for surface subsidence induced by his production of geopressured brines.

Summary

It may one day be possible to establish that the production of large volumes of geopressured brine from deep subsurface reservoirs causes surface subsidence. If this proves to be the case, the producers of those brines can expect to find themselves exposed to large financial liabllity for actions which were undertaken in earlfer times when that casual relationship was not understood. The law governing this 1tability will not spring from the cases, such as the Friendswood case, which deal with subsidence induced by the production of groundwater or the activities of underground conservation districts. This liability will instead be based on law and cases which address the penalties for 
removal of the lateral or subjacent support of surface land; the commercial exploitation of underground minerals by mining industries in other states and other common law jurisdictions has given rise to a rather mature body of law and insurance custom on the matter of removal of subjacent support. It is to this law and to insurers operating in the underground mining industry that the geopressured-geothermal resource developer should turn for guidance and protection. 
7. GEOPRESSURED-GEOTHERMAL INFORMATION SYSTEM

\subsection{OVERVIEW}

The Geopressured-Geothermal Information Systems (GGIS) has developed a large number of computerized data bases which serve as a tool for geopressured geothermal researchers. This body of information forcuses on the Gulf Coast Basin and includes information such as digitized well logs, well header information, salinity data, sand profiles, a geopressured geothermal bibliography and thesaurus, and several other data bases.

To augment the use of these data bases, many specialized software packages have been written which analyze this data and produce statistical information, graphical presentations, and reports for the use of geopressure research teams. These software packages range in scope from well $\log$ analysis packages to software which generates computer listings of the geopressured geothermal bibliography.

\subsection{TASKS ACCOMPLISHED}

The following tasks have been accomplished during the preceding contract year.

\subsection{Geopressured Analysis Program}

The ANALYZE package of subroutines was augmented to perform the following well $\log$ analysis capabilities;

1. Normalize the Spontaneous Potential (SP) baseline to zero millivolts and plot the resulting SP curve versus depth. This is done by identifying the shale points on the $\log$ and their deviation from the zero millivolt SP level. A corresponding "complementary" 
function is deveoped and this function is used to determine the SP shift necessary at each two foot location to cause the shale baseline to fall along the zero millivolt line. This method has been compared to manual computations for several logs and proves to give results with at most $10 \%$ error while the normal errors are on the order of two to three percent.

2. Calculate formation water resistivity $\left(R_{M}\right)$. The SSP is used to calculate the formation water resistivity of any desired porous and permeable zone. The user is provided three options to calculate these conate water resistivities.

The first method the user may choose to calculate the water resistivity is from inversion of the modified Nearnst Equation $\left(S S P=-K \log R_{m f e} / R_{w e}\right)$. In this method, SSP is the static spontaneous potential, $R_{\text {mfe }}$ is resistivity of the mud filtrate (assumed to be present in the "invaded zone"), and $K$ is assumed to be dependent only upon formation temperature. $R_{\text {we }}$ is the equivalent formation water resistivity.

The second method also use the modified Nearnst Equation but in this instance $k$ is assumed to be a function of mud density. Accordingly, Schlumbergers Chart Gen 7 (K versus mud density) is used to determine the $K$ value given the appropriate mud density. This method is applicable where relatively light non lignosulfonate muds have been used in the drilling program.

The third method is a modification of the second method in which $K$ is again a function of mud density; however, an empirical 
curve for heavy lignosulfonate muds (used in drilling geopressured formations) is used rather than Schlumbergers Chart Gen 7.

3. Calculate the formation salinity (PPM) and plot the salinity versus depth. This is done in a straightforward manner from the formation water resistivity. Salinities versus depth are plotted and these profiles are used in determining the geopressured transition zones as well as gas/water ratios in the geopressured aquifers.

4. Calculate $R_{w a}$ and plot versus depth. The apparent water resistivity is calculated for $100 \%$ water saturation for zones from:

$$
R_{W}=R_{i 1} / F
$$

where $F$ is the formation resistivity factor and for sandstones is assumed to be

$$
F=(\text { Theta } t) \cdot 2 / 0.81
$$

$R_{i 1}$ is the true bulk resistivity as read from the deep reading resistivity sonde (uncorrected for borehole effects). Theta $t$ is the true formation porosity and is obtained from the sonic porosity by:

$$
\text { Theta } t=\text { Sonic porosity } / C_{p}
$$

where $C_{p}$ is the compaction coefficient which is estimated from regional porosity versus depth curves for a particular area. $R_{\text {wa }}$ is hence calculated by:

$$
R_{w a}=\left(R_{i 1} \cdot 0.81 \cdot\left(C_{p} \cdot 2\right)\right) / \text { Sonic Porosity } \cdot 2
$$

A plot of $R_{\text {wa }}$ versus depth is provided.

5. Plot temperature versus depth curves.

6. Plot mud weights versus depth. 
These subroutines are specifically taflored for geopressured formations where salinity values are of importance in determining the gas/water ratio in geopressured aquifers.

Several software packages were written to make use of existing data bases which are maintained by the GGIS. These packages produce graphical presentations of the the data contained in the data bases in ways which may be useful to geopressured researchers. Examples of these packages are the following:

1. Provide distribution maps of well locations contained in the digitized well log data base. These maps are centered on identified geopressured fairways along the Texas Gulf Coastal Plain. The maps present well location, county boundaries, and township-range lines for reference.

2. Provide cross-plots of temperature versus depth or pressure versus depth for selected areas. These plots are color coded so that points above the geopressured zone are presented in one color while points below the geopressured zone are presented in another color.

3. Provide isotherm and isobar maps over selected areas. The maps are produced in a suite of plots describing a selected area. The first plot in the series locates the area of interest with county boundaries and county names being displayed. The second plot then displays an isotherm map of the area which is obtained from data in the GGIS well header data base. The contour lines on this map are color coded so that cooler and hotter areas on the map are easily identifiable. Additionally, well locations and county lines ares displayed on the map. The third of the series duplicates the 
second plot with the exception that contour lines are now shaded in so the user is presented with a solid area filled map. The fourth map is a three dimensional perspective of the isotherm map. The series is then repeated for pressure distribution. Please see figure one for examples of computer graphics applications to geopressured-geothermal research.

\subsection{Log Digitizing}

1. The digitized well log data base was expanded to $19,249,449$ feet of digitized well logs. This represents 1884 curves from 374 wells which are distributed along the Texas Gulf Coastal Plain. Numerous sonic and density logs were digitized for the Bureau of Economic Geology.

2. The Department of Petroleum Engineering acquired a Terak-8510/A microcomputer to augment the digitizing capabilities of the project. The Terak-8510/A is a DEC LSI-11/3 microcomputer with two eight inch IBM-3740 compatible disk drives, two serial RS-232c ports, and $32 \mathrm{~K}$ of sixteen bit words worth of memory. Digitizing routines have been written for the microcomputer. Additionally, well logs which have already been digitized with the existing Data General Nova system have been down loaded to the microcomputer. Software has been written which will take these digitized well logs and display them on the monochrome raster display of the Terak. Development of well log analysis routines for the microcomputer is currently underway. Portions of this software package were 


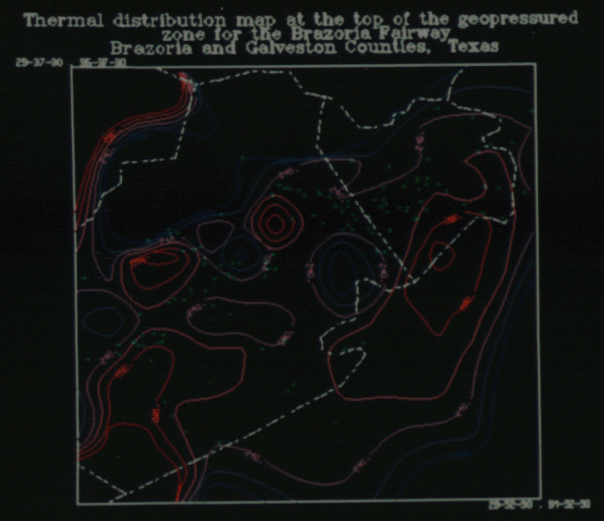

005

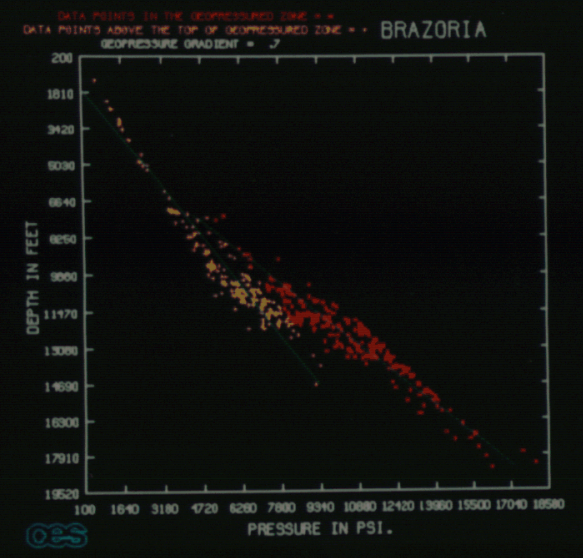

Austin Bayou Geopressured Reservoir Study Brazoria County, Texas Areal Pressure Distribution

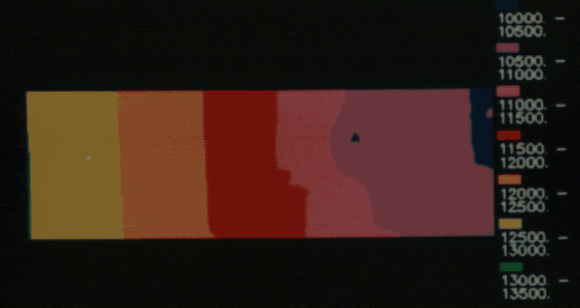

Time $=365$ days $(1$ year $)$

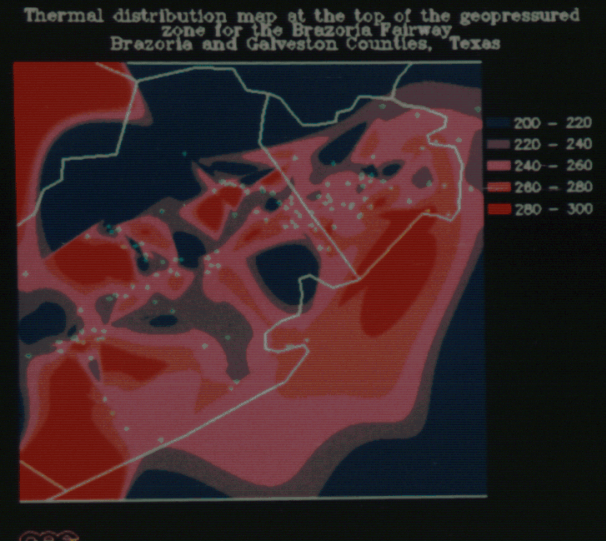

aes

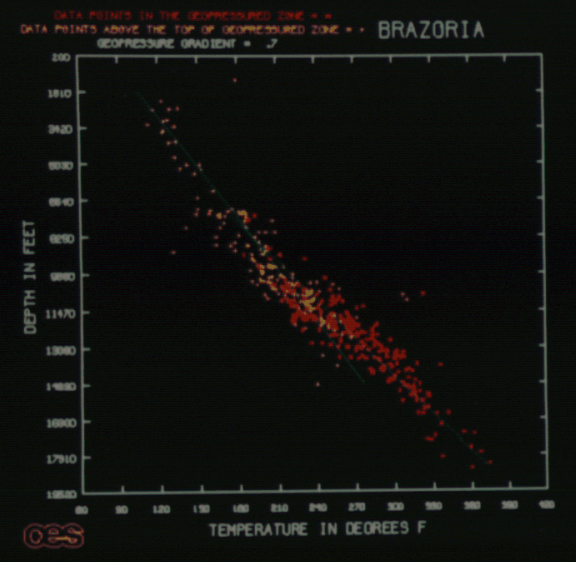

Austin Bayou Geopressured Reservoir Study Brazoria County. Texas Areal Pressure Distribution

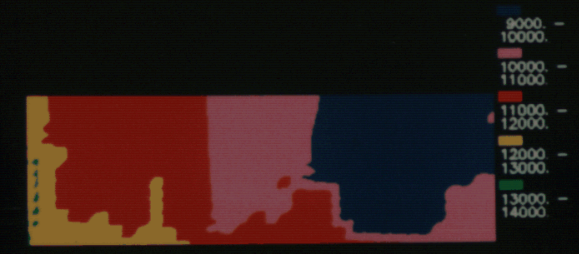

Time $=3650$ days $(10$ years $)$

@es

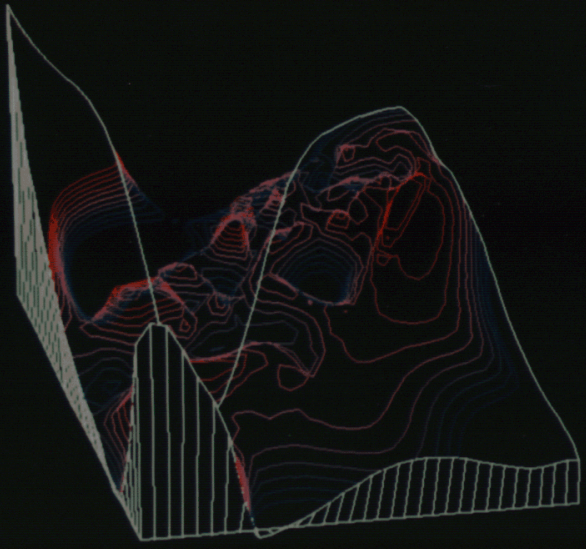

Austin Bayou Geopressured Reservoir Study Brazoria County. Texas Areal Pressure Distribution

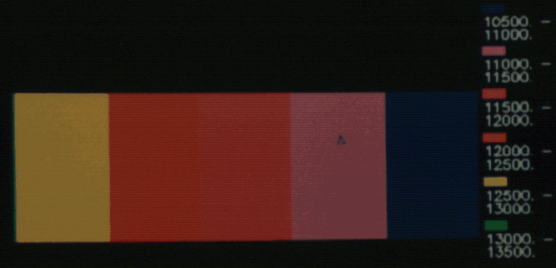

Initial Reservoir Condition ces

Austin Bayou Geopressured Reservoir Study Brazoria County, Texas

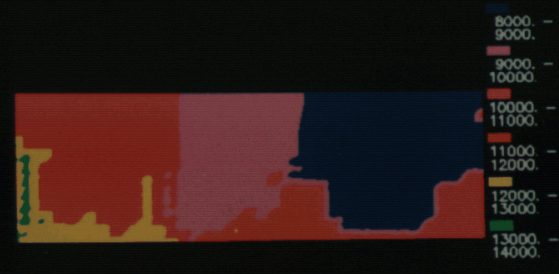

Time $=7300$ days $(20$ years $)$ 
demonstrated at the ACM SIGGRAPH convention in Dallas during August 1981 .

3. A summary index (1) of the digitized well log data base was published for use by geopressured researchers as a guide to well log data available through GGIS.

\subsection{Geopressured-Geothermal Bibliography and Thesaurus}

The "Geopressured-Geothermal Bibliography: Volume I (Citation Abstracts)" (2) and "Geopressured-Geothermal Bibliography: Volume II (Geopressure Thesaurus)" (3) were published in August 1981. The bibliography and its companion thesaurus have been compiled to assist research in the area of geopressured-geothermal energy. The bibliography is currently the most specialized and comprehensive reference work on this subject. Volume I contains over 750 bibliographical entries concerned with the scientific and technical requirements of geopressured-geothermal energy research and development, the social and environmental effects of geopressured-geothermal energy development and use, as well as the legal, economic, and financial aspects of its development and use. Each entry contains the pertinent bibliographical data, notes the availability of the document, and lists a set of descriptors (that have been assigned from the thesaurus, and which index the entry). Most entries also contain an abstract. Upon publication, the "Geopressured Thesaurus" contained more than 2800 terms and references. Both of these publications are currently avallable from the National Technical Information Service. 
Subsequent to publication of the bibliography, all activities required for publication of an updated, revised, and expanded second edition have been pursued by the GGIS staff. As of December 31,1981 , there were 202 new bibliographical entries to be included in the second edition, and several new terms had been added to the thesaurus.

Some industry interest has been generated by the publication of the bibliography, as the GGIS has handled several requests for information from private industry.

\subsection{Services to Other Users}

The GGIS provided the following services during the preceding contract year:

1. Digitized numerous maps and well logs for the Bureau of Economic Geology and the Department of Geological Sciences.

2. Provided a magnetic tape containing a listing of names and addresses in the GGIS mailing list to Louisiana State University.

3. Provided color graphics plotting routines to other projects sponsored by the Center for Energy Studies and the Department of Petroleum Engineering.

4. Provided computer 1istings of the "Geopressured-Geothermal Bibliography" to several private companies who requested that ilsting.

\subsection{REFERENCES}

1. Hill, Thomas R., Sepehrnoori, Kamy "Summary of LOGDEX Data Base", University of Texas at Austin, Center for Energy Studies, 1981. 
2. U.S. Department of Energy, National Technical Information Service "Geopressured-Geothermal Bibliography: Volume I (Citation Abstracts)" Washington, D.C., DOE/ET/27018-1 Vol. 1, DE 82002668>, 1981.

3. U.S. Department of Energy, National Technical Information Service "Geopressured-Geothermal Bibliography: Volume II (Geopressured Thesaurus)" Washington, D.C., DOE/ET/27018-1 Vol. 2, DE 82002668>, 1981. 
Reference for Figure One

$\begin{array}{lll}\text { Frame } 1 & \text { Frame } 2 & \text { Frame } 3 \\ \text { Frame } 4 & \text { Frame } 5 & \text { Frame } 6 \\ \text { Frame } 7 & \text { Frame } 8 & \text { Frame } 9\end{array}$

1. Thermal distribution map at the top of the geopressured zone in the Brazoria Fairway, Brazoria and Galveston Counties, Texas.

2. Thermal distribution map at the top of the geopressured zone in the Brazoria Fairway, Brazoria and Galveston Counties, Texas.

3. Three dimensional perspective view of the thermal distribution at the top of the geopressured zone in the Brazoria Fairway, Brazoria and Galveston Counties, Texas.

4. Plot of pressure versus depth for Brazoria County, Texas.

5. Plot of temperature versus depth for Brazoria County, Texas.

6. Initial reservoir condition for reservoir simulation study of the Austin Bayou Geopressured Reservoir Study, Brazoria Country, Texas.

7. Reservoir condition after one year for reservoir simulation study of the Austin Bayou Geopressured Reservoir Study, Brazoria County, Texas.

8. Reservoir condition after ten years for reservoir simulation study of the Austin Bayou Geopressured Reservoir Study, Brazoria County, Texas.

9. Reservoir condition after twenty years for reservoir simulation study of the Austin Bayou Geopressured Reservoir Study, Brazoria County, Texas. 
8. STUDY OF LOG DERIVED WATER RESISTIVITY VALUES IN GEOPRESSUREDGEOTHERMAL FORMATIONS

The following progress reports have previously been submitted to the Department of Energy. 
PROGRESS REPORT \#13, MARCH 1981

STUDY OF LOG DERIVED WATER RESISTIVITY DATA IN

GEO $^{2}$ FORMATIONS

SUMMARY:

We have obtained recent test data from Houston 011 and Minerals Prairie Canal \#1, Calcasieu Parish, La., and have added this as test \#25 to our set of data. Results are shown in Table 2. For this well, use of the header data on RMF gives a good check of observed and calculated water resistivitles (very unusual).

We have done further work on the salinity correction curve shown as Fig 1 of last month's progress report. The two branches of this curve do appear to be correlateable with geologic age, confirming our guess of last month. All points on the upper branch of the curve are lower Frio and younger, all points on the lower branch are lower Frio and older.

At the request of $\mathrm{Mr}$. Keith Westhusing, we attended a meeting at Ben Eaton's Offices on March 24 to discuss methods of calculating water resistivity from the S.P., using the F. A. Godchaux III \#1 well as an example. At this meeting I was requested to summarize my recommendations for calculating the formation water salinity from the S.P. In geopressured wells drilled with Iignosulfonate muds. This was done, and reported to Westhusing in a letter dated Apr11 1, 1981 (attached). Using the method outlined, we should be able to calculate the water salinity within $\pm 21,000 \mathrm{ppm}$ std. dev.

At the same meeting, Prof. Zaki Basslouni of the Petroleum Engineering Dept. at L.S.U. outlined a new method of calculating the formation water resistivity from the S.P. He had applied this to a set of water data from a rather Iimited area of $\mathrm{S}$. Loulsiana with good results. We plan to apply his method to our set of water data taken from a much wider area of the Texas and Loulsiana Gulf Coast to see if it is broadly applicable.

\section{DISCUSSION:}

Test 非5, Houston 011 and Minerals Prairle Canal \#1, Calcasieu Parish, La., has recently been completed and data from this well has been added to our data bank. We have no measured formation water resistivity, but the reported 42,500 ppm T.D.S. (Ben Eaton) implies a water resistivity of $045 \Omega \mathrm{M}$ (e) $264^{\circ} \mathrm{F}$ well temperature, if the $42,500 \mathrm{~T} . \mathrm{D} . \mathrm{S}$. Is all NaC1. The $264^{\circ} \mathrm{F}$ well temperature at test depth was obtalned from the observed well temperature at total depth of $15,658^{\prime}$ of $282^{\circ} \mathrm{F}$, using an assumed temperature gradient at depth of $2 \mathrm{~F} / 100 \mathrm{ft}$. (Only one $10 \mathrm{~g}$ run was avallable). The results of the calculations are shown in Table 2. It is interesting (and very unusual) that in this case the use of the header value of RMF gave the best check of observed water resistivity.

Additional work on the salinity correction curve reported as Fig 1 of last month's progress report confirms our guess that the data for the two branches of this curve correlate with geologic age. (See Fig. 5) There is 
some uncertainty about assigning tests to the lower or upper branch of the salinity curve if the age is in the lower Frio. In such cases, an assignment based on geography should be used (all tests on the lower branch are from Texas, most tests on the upper branch are from Louisiana.) Also, in some cases, assignment of a test to the lower branch will lead to an Impossibly high value of salinity.

At the request of $\mathrm{Mr}$. Keith Westhusing on March 24, we have summarized our recommendations for the best method of calculating water salinity. from the S.P. (See attached letter to Westhusing, dated Apri1 1, 1981). This is self explanatory except for a comment about the "final" correction referred to in the letter. After making the salinity correction based on geologic age, I expected that the salinity values would scatter about a $45^{\circ}$ line when plotted against true salinity, and was surprized when they did not. (See Fig 3 of the letter). Since there st111 appeared to be a systematic difference between Salinity 2 and true salinity, I fitted a curve to the observed points as shown, and corrected using the fitted line to obtain Salinity 3, the present best estimate of calculated salinity. Fig. 4 shows the scatter of Sglinity 3. As you can see, the scatter is now falrly random relative to the $45^{\circ}$ line, implying that most of the systematic error has been removed.

Prof. Zaki Basslouni of L.S.U. presented a new method for calculating the water resistivity from the S.P., which uses the shale resistivity as a parameter to measure the effectiveness of the shale membrane in selectively transporting the $\mathrm{Na}^{+}$lon. His data were all derived from a limited area in Louislana, however, and here the method worked well. I will try to extend his method to the much broader data base I have been working with, using tests extending all along the Texas and Loulsiana Gulf Coasts.

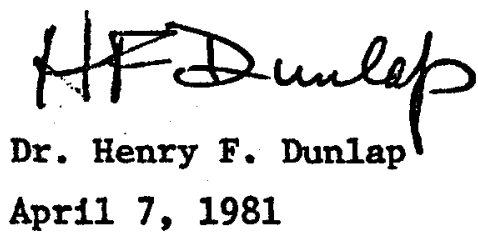


TABLE 2

MEASURED \& S.P. DERIVED WATER DATA FROM $\mathrm{GEO}^{2}$ RESERVOIRS

\begin{tabular}{|c|c|c|c|c|c|c|c|c|c|c|c|}
\hline & & & Sand & We11 & & Meas. Rw & Calc. Rw SP & Calc. Rw SP & Calc. $\mathrm{Rw}$ SP & \multicolumn{2}{|c|}{ Mud Type } \\
\hline $\begin{array}{c}\text { Test } \\
\# \equiv\end{array}$ & $\begin{array}{l}\text { We11 } \\
\text { Name }\end{array}$ & Location & $\begin{array}{l}\text { Depth } \\
\text { (Ft.) }\end{array}$ & Temp $_{\mathrm{F}}$ & $\begin{array}{l}\text { Dens. } \\
\text { \#/Gai }\end{array}$ & $\begin{array}{l}\text { at We11 } \\
\text { Temp } \Omega M\end{array}$ & $\begin{array}{c}\text { (Header) } \\
\Omega \mathbf{M}\end{array}$ & $\begin{array}{c}(\text { Gen } 7) \\
\Omega \mathrm{M}\end{array}$ & $\begin{array}{c}\text { (Curve) } \\
\Omega M\end{array}$ & $\begin{array}{l}\text { Header } \\
\text { Data }\end{array}$ & Basic \\
\hline 25 & $\begin{array}{l}\text { Houston } \\
\text { O11 } \\
\text { Prairie } \\
\text { Canal 非 }\end{array}$ & $\begin{array}{l}\text { Calcasieu } \\
\text { Parish, } \\
\text { La. }\end{array}$ & $\begin{array}{c}14,775- \\
820\end{array}$ & $264^{\circ}$ & 17.3 & .045 & .045 & .039 & .021 & LIgno. & $\begin{array}{r}\text { Ligno. } \\
\infty \\
\&\end{array}$ \\
\hline
\end{tabular}




\section{THE UNIVERSITY OF TEXAS AT AUSTIN \\ DEPARTMENT OF PETROLEUM ENGINEERING \\ AUSTIN, TEXAS 78712}

Petrolexm Engineering Building 211

Area Code $512 \quad 471.3161$

April 1, 1981

Mr. Keith Westhusing

Geopressure Projects Office

U.S. Department of Energy

Federal Building and Courthouse, Sulte 8620

515 Rusk Ave.

Houston, Texas 77002

Dear Keith:

Following our meeting at Eaton's office on March 24th, I have done additional work on the age correction plot we discussed there, and have also included results from the Houston 011 and Minerals Prairie Canal \#1, which was not previously avallable to me. The results are shown in the attached tables and graphs. Based on the 16 deep hot wells using lignosulfonate muds for which we have data, the standard deviation in 8 calculated salinity for 12 tests with true salinity between 73,000 and 190,000 $\mathrm{ppm}$ is $\pm 16 \%$. We have no tests with salinity between 42,500 and 73,000 ppm. We have four tests with salinity between 9300 and 42,500 , with standard deviation in $\%$ calculated salinity of $\pm 69 \%$.

The high $\%$ error in calculated salinity for low values of true salinity is reasonable when we consider the error in calculated salinity in ppm, and not as $\%$ error. From Table 1 we see that the errors range from 0 to 52,000 ppm, with no concentration of larger errors at low salinities. The standard deviation in calculated salinities, expressed in ppm. is $\pm 21,000 \mathrm{ppm}$ using all 16 tests. With this uncertainly in calculated salinity, high \% errors for waters with salinities of 40,000 ppm or less follow automatically.

The above results were obtained as follows:

(1) RMF is obtained from RM (Header Value) using figure 1 (This is a replot of Figure 1 from 6th Progress Report) 
(2) Rwl at formation temperature is obtained using conventional calculation techniques, (as outlined in my letter to you of February 26, 1981 with example calculation for FA Godchaux III \#1 well.)

(3) Salinity 1 is obtained from Rwl using Schlumberger Chart Gen 9 (1972 Chartbook) or the equivalent.

(4) "Age" correction is applied to salinity 1 to obtain salinity 2 using figure 2. This is a slightly modified version of the salinity correction chart attached to my letter to you of February 26, 1981. The additional point for the Prairie Canal well has been added, and the curves for the upper branch (lower Frio and younger) and lower branch (lower Frio and older) have been slightly shifted and with an extrapolation to 0 salinity sketched in.

(5) A "Final" correction is applied using figure 3, which is a plot of salinity 2 obtained from Figure 2, vs. true salinity. This gives salinity 3 , which is my best estimate of true calculated salinity. The standard deviations quoted in the first paragraph of this letter are for salinity 3 estimates.

Actually these results are suprisingly good when the large uncertainties in $\mathrm{Rm}$ implied by the Imco data reviewed in Progress Report 12 are considered. These errors in $\mathrm{Rm}$ can and do exceed 100\%, and are almost certainly the controlling factor in calculating water resistivity from the S.P. Until this uncertainty (in $\mathrm{Rm}$ ) is under better control, it appears of little value to try to "fine tune" the calculation in other ways.

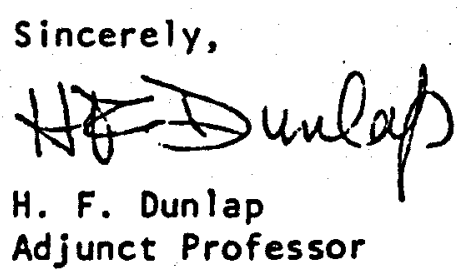

cc: Myron 4. Dorfman/Cha irman Petroleum Engineering,U.T. Ray Grzgory/Bureau of Economic Geology, U.T. Raymond H. Wallace/U.S.G.S. Zaki Bassiouni/L.S.U., Petroleum Engineering Dept. Don Bebout/D.N.R., LA. 


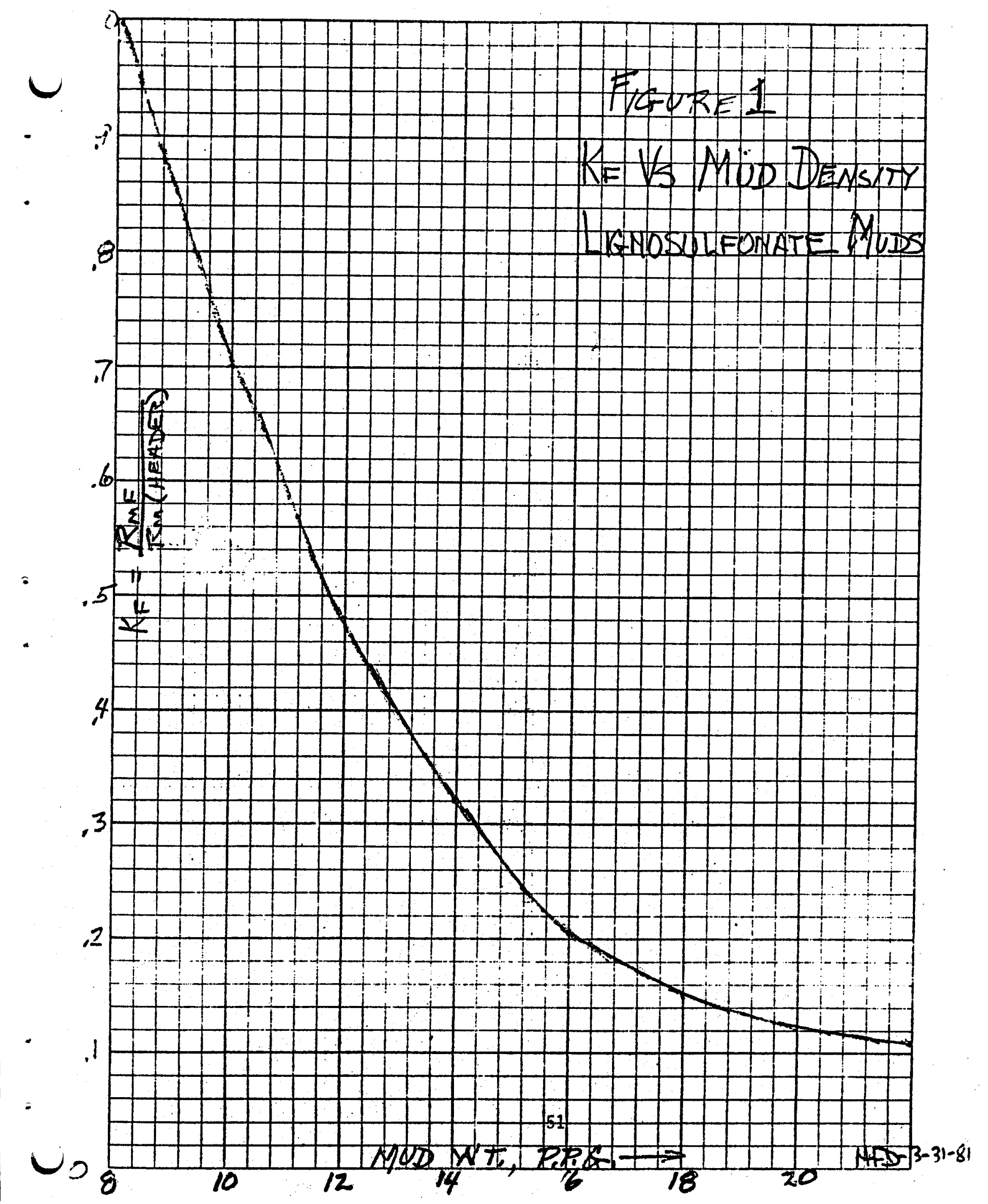




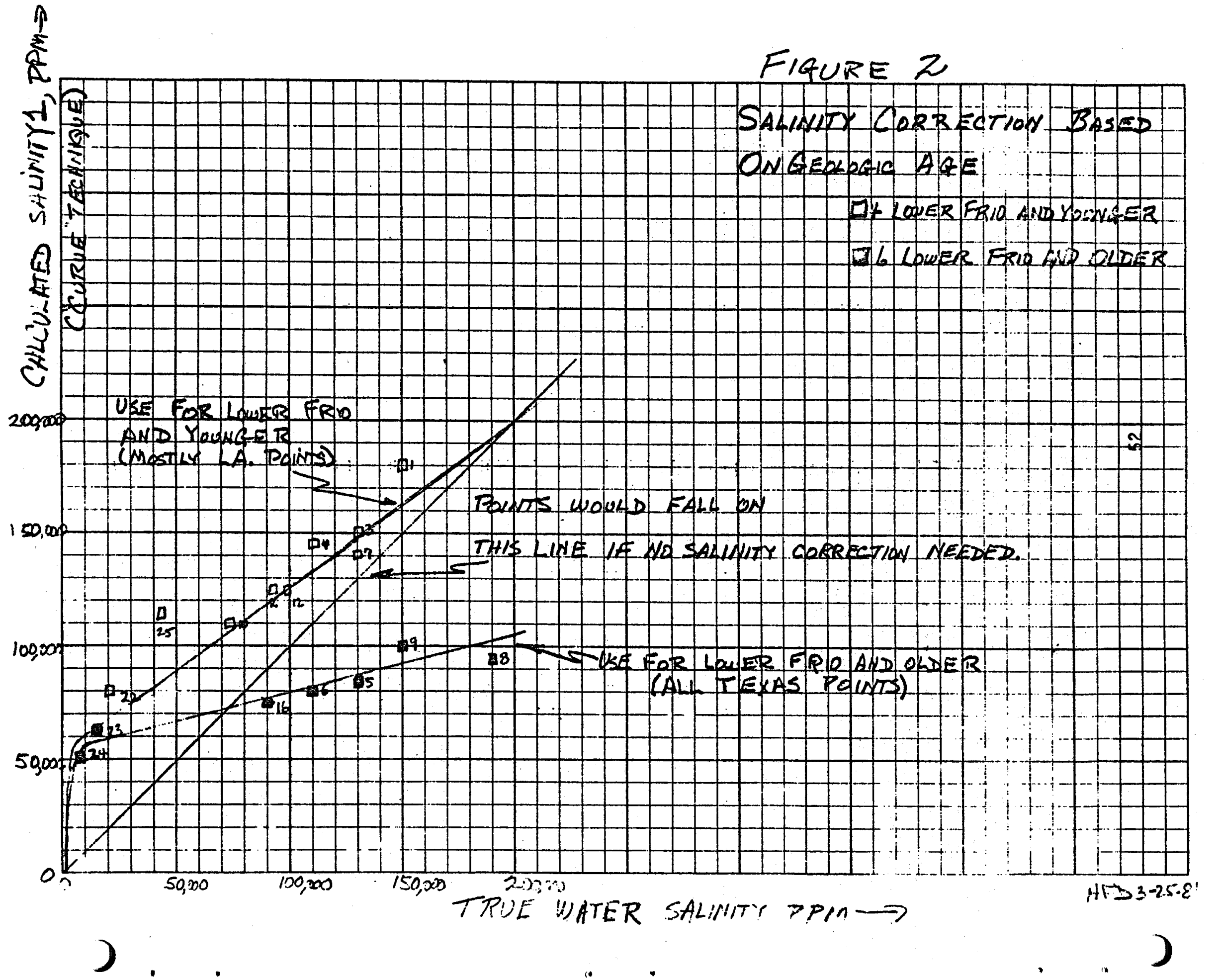




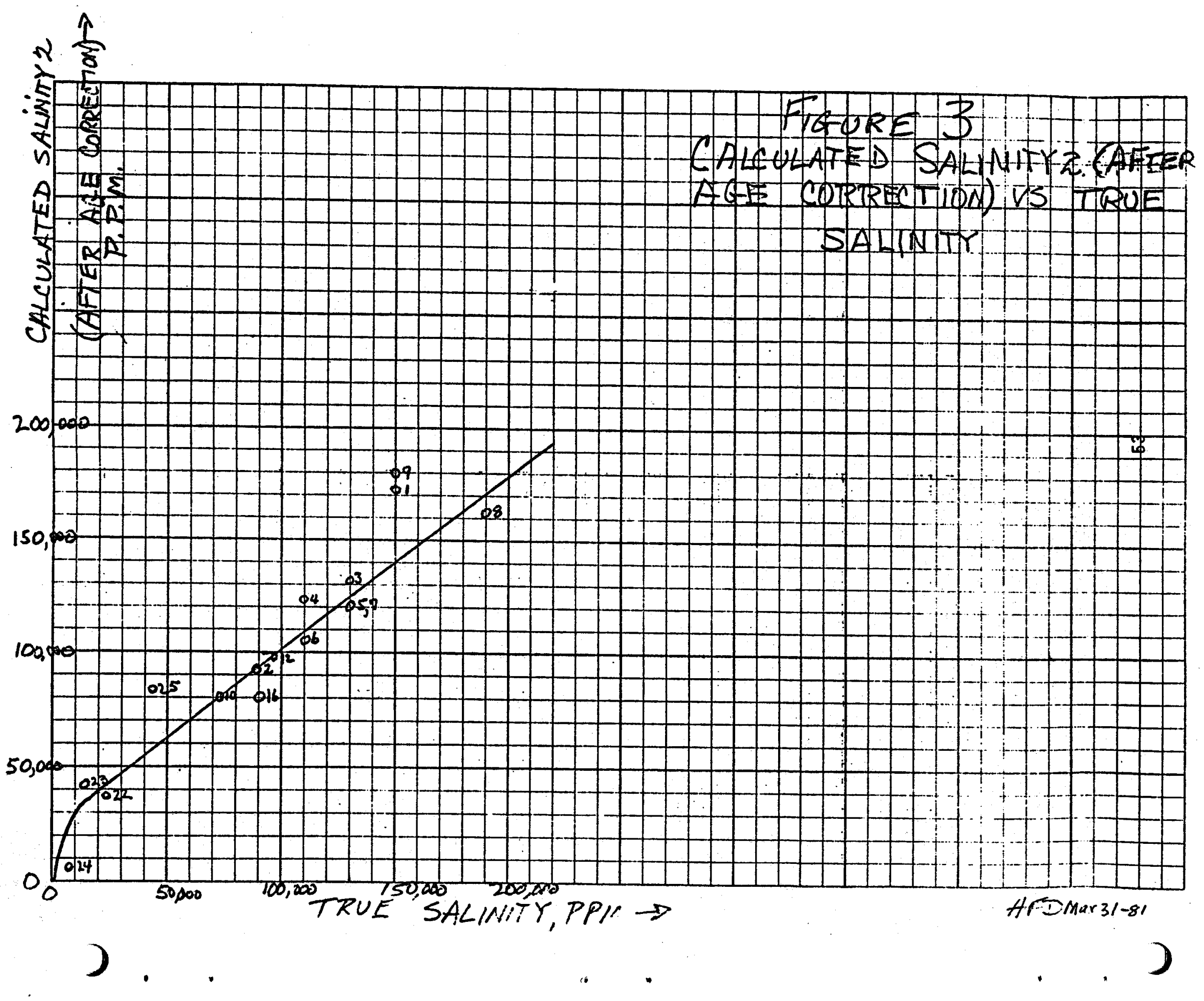


Table 1

Data for Salinity Calculations in Deep Hot Wells Orilled with Lignosulfonate Muds

Salinity 3

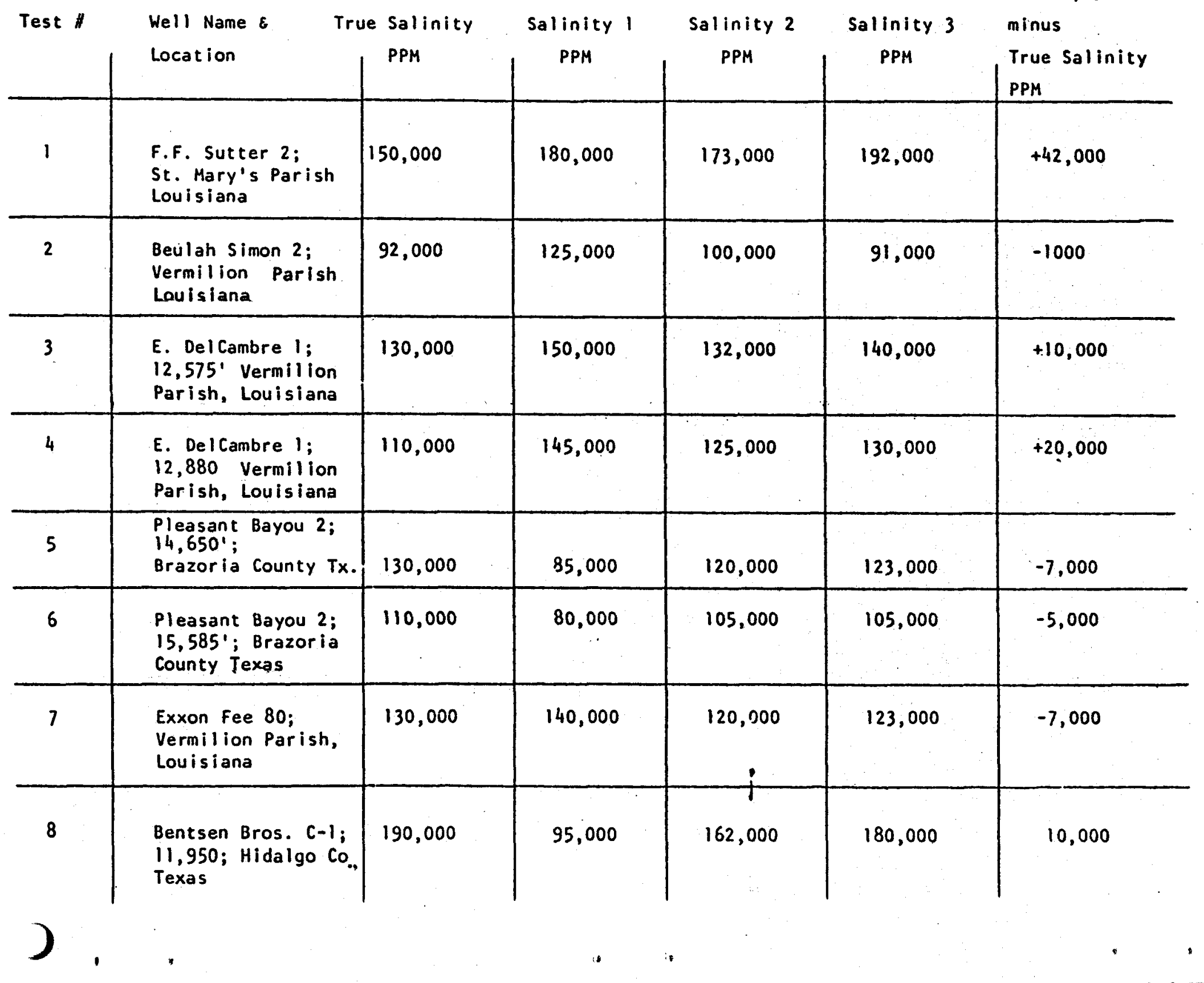




\begin{tabular}{|c|c|c|c|c|c|c|}
\hline 9 & $\begin{array}{l}\text { Bentsen Bros. C-1; } \\
\text { 12,070; Hidalgo } \\
\text { County Texas }\end{array}$ & 150,000 & 100,000 & 180,000 & 202,000 & $+52,000$ \\
\hline 10 & $\begin{array}{l}\text { Phillip Gardener } \\
\text { \#1; Brazoria County, } \\
\text { Texas }\end{array}$ & 73,000 & 110,000 & 80,000 & 73,000 & 0 \\
\hline 12 & $\begin{array}{l}\text { Exxon Armstrong 46; } \\
\text { Kenedy County, } \\
\text { Texas }\end{array}$ & 98,000 & 125,000 & 98,000 & 98,000 & 0 \\
\hline 16 & $\begin{array}{l}\text { Humble Armstrong 2; } \\
\text { Kenedy County, Tx. }\end{array}$ & 90,000 & 74,000 & 80,000 & 72,000 & $-18,000$ \\
\hline 22 & $\begin{array}{l}\text { Wa inoco Giraurd 1; } \\
\text { Layfayette P. LA. }\end{array}$ & 22,000 & 80,000 & 38,000 & 18,000 & $-4,000$ \\
\hline 23 & $\begin{array}{l}\text { Lear Koelemay 1; } \\
\text { Jefferson County, } \\
\text { Texas }\end{array}$ & 15,000 & 64,000 & 44,000 & 22,000 & $+7,000$ \\
\hline 24 & $\begin{array}{l}\text { Riddle Saidana } 2 \text {, } \\
\text { Zapata County Texas }\end{array}$ & 9273 & 51,000 & 7,000 & 2000 & $-7,000$ \\
\hline 25 & $\begin{array}{l}\text { Houston Oil Prairie } \\
\text { Canal 1; Calcasieu } \\
\text { P. LA. }\end{array}$ & 42,500 & 115,000 & 83,000 & 75,000 & $+33,000$ \\
\hline & . & & & & & \\
\hline & & &. & & & . \\
\hline
\end{tabular}




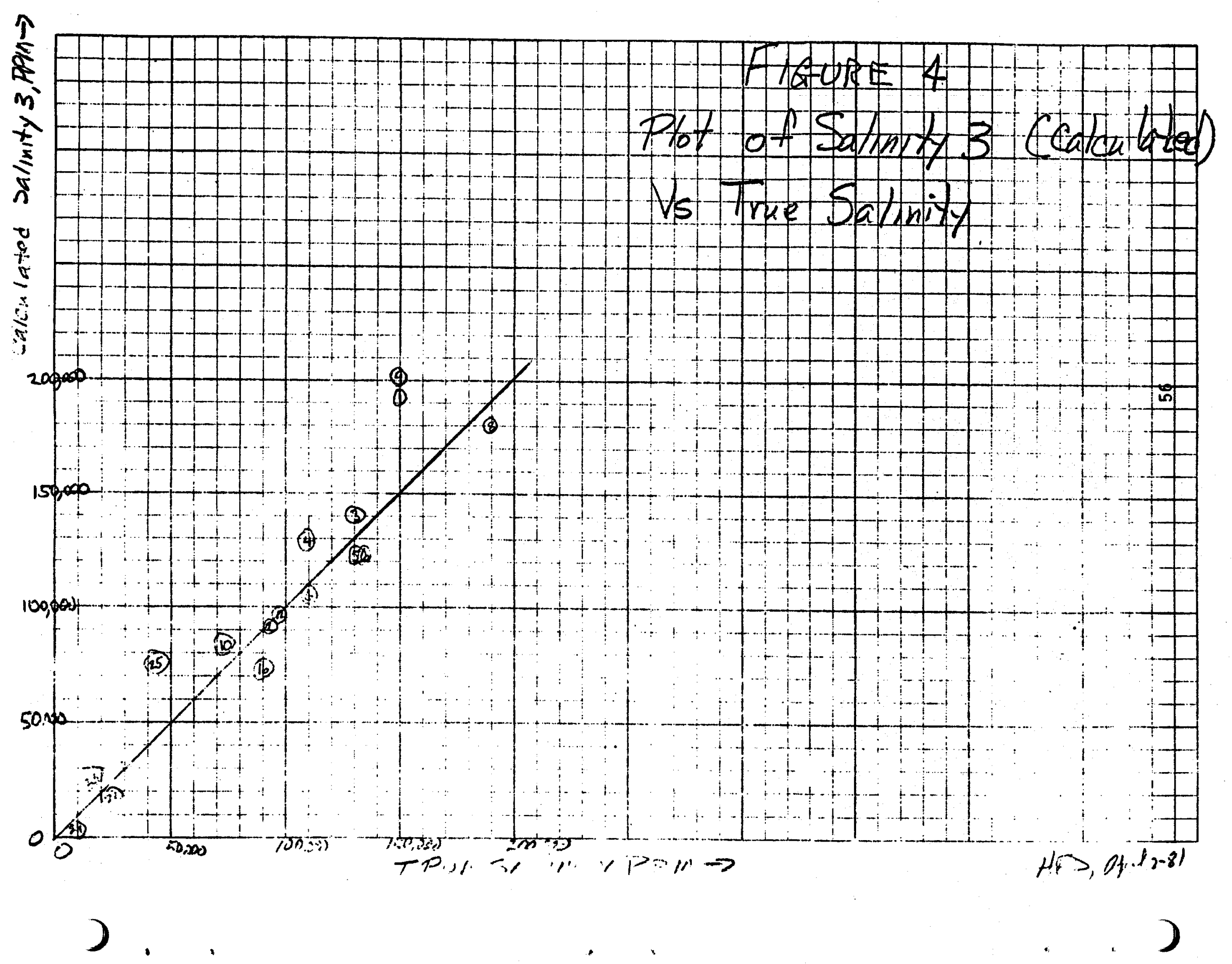




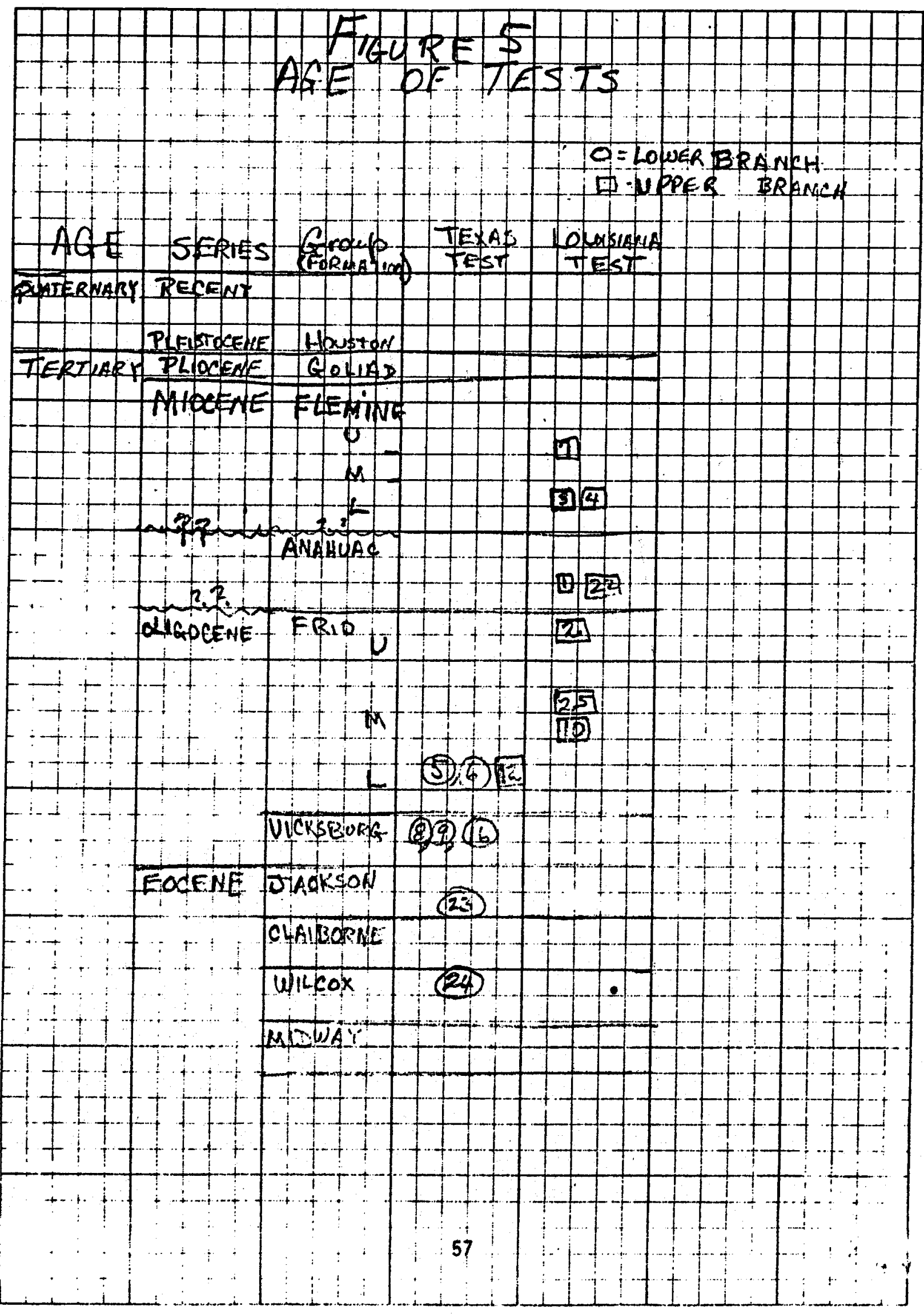


PROGRESS REPORT \#9, NOV. 1980

"STUDY OF LOG DERIVED WATER RESISTIVITY DATA

IN GEO ${ }^{2}$ FORMATIONS"

SUMMARY: We have begun experimental work using the borrowed equipment and supplies, but the materlal ordered in early November has not been obtained as yet. Red tape requirements for multiple bids, etc. would greatly interfere with efficient prosecution of the experimental work if we had not been able to borrow equipment.

Tests run on low and high density muds indicate an increase in mud filtrate $v$ iscosity by a factor of 1.2 to 1.5 relative to water viscosity for low density "standard" mud, but no increase in filtrate viscosity was observed for the high density standard mud, nor for the 1ignosulfonate muds tested, whether low or high density. We don't understand this, but have too little data to generalize as yet. Test of a .57\% mixture of chrome 1ignosulfonate and water showed no increase in viscosity over water viscosity, so whatever is increasing the filtrate viscosity is probably not lignosulfonate alone. Tests of bentonite-water slurrles showed viscosity increase over water viscosity of about $3 \%$ for a $\frac{1}{4} \%$ bentonite slurry, and about $17 \%$ for a $\frac{1}{2} \%$ bentonite slurry. We are encouraged that some of the filtrates studied show a significent increase in viscosity, but we certainly don't understand everything that is going on here as yet.

We have thought of another effect which undoubtedly affects our calculation of water resistivity, and which would tend to cause calculation of too salty a formation water, as was the case for tests 23 and 24 , the Koelemay and Saldana wells reported last month. Most deep hot wells are drilled with caustic treated muds, with $\mathrm{pH}$ ranging from 9 to above 12.5 . The effect of the $\mathrm{OH}$ Ion in high $\mathrm{pH}$ muds is to cause an overestimation of filtrate salinity, and hence an overestimation of formation water salinity. This can be seen by referring to Fig. 1 (chart Gen-8 in the Schlumberger chart book). This chart shows $\mathrm{OH}$ Ions to be 5.5 times as effective in carrying current as C1 lons. The result is that in $13 \mathrm{pH}$ mud, for example, the $\mathrm{N}_{a} \mathrm{C}_{1}$ concentration estimated from a resistivity measurement is too high by $9350 \mathrm{ppm}$; for a pH $12 \mathrm{mud}$, the error is $935 \mathrm{ppm}$, etc. The solution may be to measure the Na ion activity directly in the mud filtrate using a specific ion electrode of the type developed by Orion, rather than deducing. the Na Ion activity from a resistivity measurement.

DISCUSSION: We set up the borrowed equipment and began experimental work last month. We are st1ll working some of the bugs out, but have made some progress. Viscosity measurements, made with a capillary viscometer of the Ostwald type, are reproduceable to $\pm 3 \%$ for water. Resistivity measurements, made with a Fann type, two electrode, bridge system are usually reproduceable to a few $\%$, but occastonally larger errors are observed, probably due to bubbles in the resistivity cell. These are almost impossible to detect when opaque 11quids such as mud are in the cell. Mud density, and filtrate loss in the Barold filter press, are probably accurate to $\pm 5 \%$. Temperatures are read to $\pm \frac{1}{2}{ }^{\circ} \mathrm{C}$. 
Experiments have been carried out on low and high density versions of two muds--a "standard" mud consisting of $20 \mathrm{pds} / \mathrm{bbl}$ bentonite, $2 \mathrm{pds} / \mathrm{bbl}$ of tannex, and $1 \mathrm{pd} / \mathrm{bbl}$ of $\mathrm{NaOH}$. In lab quantities, this converts to $20 \mathrm{gm}$ bentonite $/ 350 \mathrm{CC}$ water, etc. The density of this mud is about $8.7 \mathrm{pd} / \mathrm{gallon}$. The $\mathrm{pH}$ is about 11 , and the resistivity is $1.6-$ $1.7 \Omega M @ 20^{\circ} \mathrm{C}$ for several mixes of this recipe. A dense "standard" mud is made from this low density mud by adding $452 \mathrm{gm}$ barite to obtain a density of $16.2 \mathrm{pd} / \mathrm{gallon}$.

A lignosulfonate mud was made using $15 \mathrm{gm}$ bentonite /350CC water, plus $25 \mathrm{gm}$ low yleld clay, 2 gms chrome 1ignosulfonate (Spersene) $4 \mathrm{gms}$ lignite, and $.8 \mathrm{gm} \mathrm{N}_{2} \mathrm{OH}$. This gave a mud of density $8.9 \mathrm{pd} / \mathrm{gal}$. A dense lignosulfonate mud was obtained by adding $450 \mathrm{gm}$ barite which yielded a mud of density $16.2 \mathrm{pd} /$ gallon. We will call these muds type $1,2,3$ and 4 respectively.

Tests were run on these muds as outlined in Table 1 . Repeat tests were done on separate mixes of muds 1 and 2 , which showed some variation. The resistivity variation may be due to the presence of bubbles in the resistivity cell on certain tests. We are uncertain of the cause of the other variations.

The only mud to give a filtrate with viscosity greater than water was \#1, the low density "standard" mud. This was surprising, as we had expected the high density lignosulfonate mud to show this effect. To check further on what might be causing the viscosity increase, we made up a slurry of .57\% chrome 1ignosulfonate (Spersene) in water and measured the viscosity. It showed no increase relative to water. We also made up two slurries of bentonite and water, one at $\frac{1}{4} \%$ and one at $3_{2} \%$ bentonite concentration. These showed viscosity increases of $3 \%$ and $17 \%$ respectively, relative to water.

It is possible that mud type 1 shows the observed fitrate of $20 \%$ to $50 \%$ relative to water due to bentonite passing thru the filter paper. We will do further work on this using finer filter paper. We also plan to carry out additional tests using lime and gyp base muds.

An effect which would lead to overestimation of formation water salinity may be important in high $\mathrm{pH}$ muds ( $\mathrm{pH}$ of 12 and above). Referring to Fig. 1, which gives data for converting various + and - lons to equivalent amounts of $\mathrm{Nat}$ and $\mathrm{Cl}^{-}$lons, we see that the $\mathrm{OH}^{-}$Ion 185.5 times as effective as the $\mathrm{C1}^{-}$ion in carrying current, when both ions are measured in $\mathrm{ppm}$. For a mud of $\mathrm{pH} 12$ the $\mathrm{OH}^{-}$ion concentration is $10^{-2}$ mol/1iter, or .01(17) $\mathrm{gm} / 1$ ter $=170 \mathrm{ppm}$. This much $\mathrm{OH}^{-}$ion is the equivalent of $5.5(170)=935 \mathrm{ppm} \mathrm{C1}^{-}$Ion. We interpret the resistivity data usually assuming a $\mathrm{N}_{8} \mathrm{C}_{1}$ solution, and for this assumption, we see that the high $\mathrm{pH}$ results in too low a resistivity for the mud filtrate (too salty a mud filtrate), which gives too salty a calculated formation water when the incorrect filtrate salinity is used in the calculation. 
TABLE 1

LAB TESTS ON DRILLING MUD

\begin{tabular}{|c|c|c|c|c|c|c|c|c|}
\hline $\begin{array}{l}\text { MUD } \\
\text { TYPE }\end{array}$ & $\begin{array}{l}\text { MUD } \\
\text { DESCRIPTION }\end{array}$ & $\begin{array}{l}\# / g a 1 \\
\text { MUD } \\
\text { DENSITY }\end{array}$ & $\begin{array}{l}\text { RM } \\
\text { MUD } \\
\text { RES } \odot 20^{\circ} \mathrm{C}\end{array}$ & $\begin{array}{l}\text { SM } \\
\text { MUD } \\
\text { FILT. RES. C } 20^{\circ} \mathrm{C}\end{array}$ & $\begin{array}{l}\text { MUD FILT. } \\
\text { VISC. } \\
\text { WATER VISC. }\end{array}$ & MUD $\mathrm{pH}$ & $\begin{array}{l}\text { MUD } \\
\text { FILTRATE pH }\end{array}$ & $\begin{array}{l}\text { WATER LOSS } \\
\mathrm{CC} / 30 \mathrm{~m} \text { in }\end{array}$ \\
\hline 1 & $\begin{array}{l}\text { Low Density } \\
\text { "standard" }\end{array}$ & 8.7 & $1.6+1.7 *$ & $1.6+2.0 *$ & $1.2 \rightarrow 1.5$ & 11 & 11 & $11.5 \rightarrow 12$ \\
\hline 2 & $\begin{array}{l}\text { High Density } \\
\text { "standard" }\end{array}$ & $16.1 \rightarrow 16$. & $21.9+2.1$ & $1.0+1.3 *$ & 1.0 & 9 & 9 & $15 \rightarrow 30$ \\
\hline 3 & $\begin{array}{l}\text { Low Density } \\
\text { Chrome L.S. }\end{array}$ & 8.9 & 2.9 & 1.78 & 1.0 & - & - & - \\
\hline 4 & $\begin{array}{l}\text { High Density } \\
\text { Chrome L.S. }\end{array}$ & 16.2 & 1.84 & 1.1 & 1.0 & - & - & 12 \\
\hline
\end{tabular}

* Resistivity data probably high for some tests due to air bubbles in cell.

) 
As an example of this effect, consider tool \#12, Exxon Armstrong \#46, $\log$ run $\$ 4$ from 10,710 - 13,054, where the mud $\mathrm{pH}$ was listed as 12.7 . This $\mathrm{pH}$ would correspond to an $\mathrm{OH}^{-}$Ion concentration of $10^{-1.3^{2}}=.05 \mathrm{~mol} / 1 \mathrm{iter}$, or .05 (17) $\mathrm{gm} / 1$ iter $=850 \mathrm{ppm} \mathrm{OH}^{-}$ion concentration, which would be equivalent to $5.5(850)=4675 \mathrm{ppmCl}^{-}$ion concentration. The header $\mathrm{R}_{\mathrm{MF}}$ value shown for this well was $.256 \Omega \mathrm{M}$ \& $75^{\circ} \mathrm{F}$. This is equivalent to a $\mathrm{N}_{\mathrm{a}} \mathrm{C}_{1}$ concentration of about $24,000 \mathrm{ppm}$. According to the above analysis, this salinity is high by $4675 \mathrm{ppm}$, and the correct value should be $19,325 \mathrm{ppm}$. In this case, the salinity error due to the high $\mathrm{pH}$ of the mud would be $\frac{4675}{19,325}=24 \%$. A similar analysis applied to test \#10, Phillips Gardiner \#1, $10 g$ run \#3 from 11693 - 11806, where the mud $\mathrm{pH}$ was 1 isted as 12.2 , indicates a salinity error due to high $\mathrm{pH}$ of $23 \%$. The error is about the same as before even though the $\mathrm{pH}$ is lower here because the $R_{M F}$ value for the Gardiner well was $.62 \Omega \mathrm{M}$ a $88^{\circ} \mathrm{F}$, considerably larger than for the Armstrong well. In general, the error will depend on both the $\mathrm{R}_{\mathrm{MF}}$ and $\mathrm{pH}$ values, but for practical cases, errors are not likely to be very large for $\mathrm{pH}$ values smaller than 11 to 12 . (See Figure 2).

The two wells reported last month where calculated formation water resistivity was too high had mud $\mathrm{pH}$ of 10.5 (for Lear Koelemay test) and 11.5 (for the Riddle Saldana test). This effect will not explain the test results in these two wells.

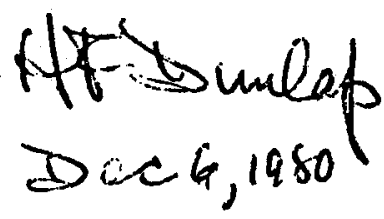




\section{RESISTIVITIES OF SOLUTIONS ${ }^{2}$}

Actual resistivity measurements are always to be preferred, but, if necessary, the resistivity of a water sample can be estimated from its chemical analysis. An equivalent $\mathrm{NaCl}$ concentration determined by use of the chart below is entered into Gen-9 to estimate the resistivity of the sample.

The chart is entered in abseissa with the total solids concentration of the sample in ppm $(\mathrm{mg} / \mathrm{kg})$ to find weighting multipliers for the various ions present. The concentration of each ion is multiplied by its weighting multiplier and the products for all ions are summed to get equivalent $\mathrm{NaCl}$ concentration. Concentrations are expressed in $\mathrm{ppm}$ or $\mathrm{mg} / \mathrm{kg}$, both by weight. These units are numerically equal.

\section{EXAMPLE}

A formation-water-sample analysis shows $460 \mathrm{ppm} \mathrm{Ca,} 1400 \mathrm{ppm} \mathrm{SO}$, and 19,000 ppm Na plus Cl.

Total solids concentration is $460+1400+19,000=20,860 \mathrm{ppm}$.

Entering the chart below with this total solids concentration, we find 0.81 as the Ca multiplier and 0.45 as the $\mathrm{SO}_{4}$ multiplier. Multiplying the concentrations by the corresponding multipliers, the equivalent $\mathrm{NaCl}$ concentration is found as approximately:

$$
460 \times 0.81+1400 \times 0.45+19,000 \times 1 \approx 20,000 \mathrm{ppm} \text {. }
$$

Entering the $\mathrm{NaCl}$ Resistivity-Salinity nomograph (Gen-9) with $20,000 \mathrm{ppm}$ and $75^{\circ} \mathrm{F}\left(24^{\circ} \mathrm{C}\right)$, the resistivity is found to be 0.3 at $75^{\circ} \mathrm{F}$.

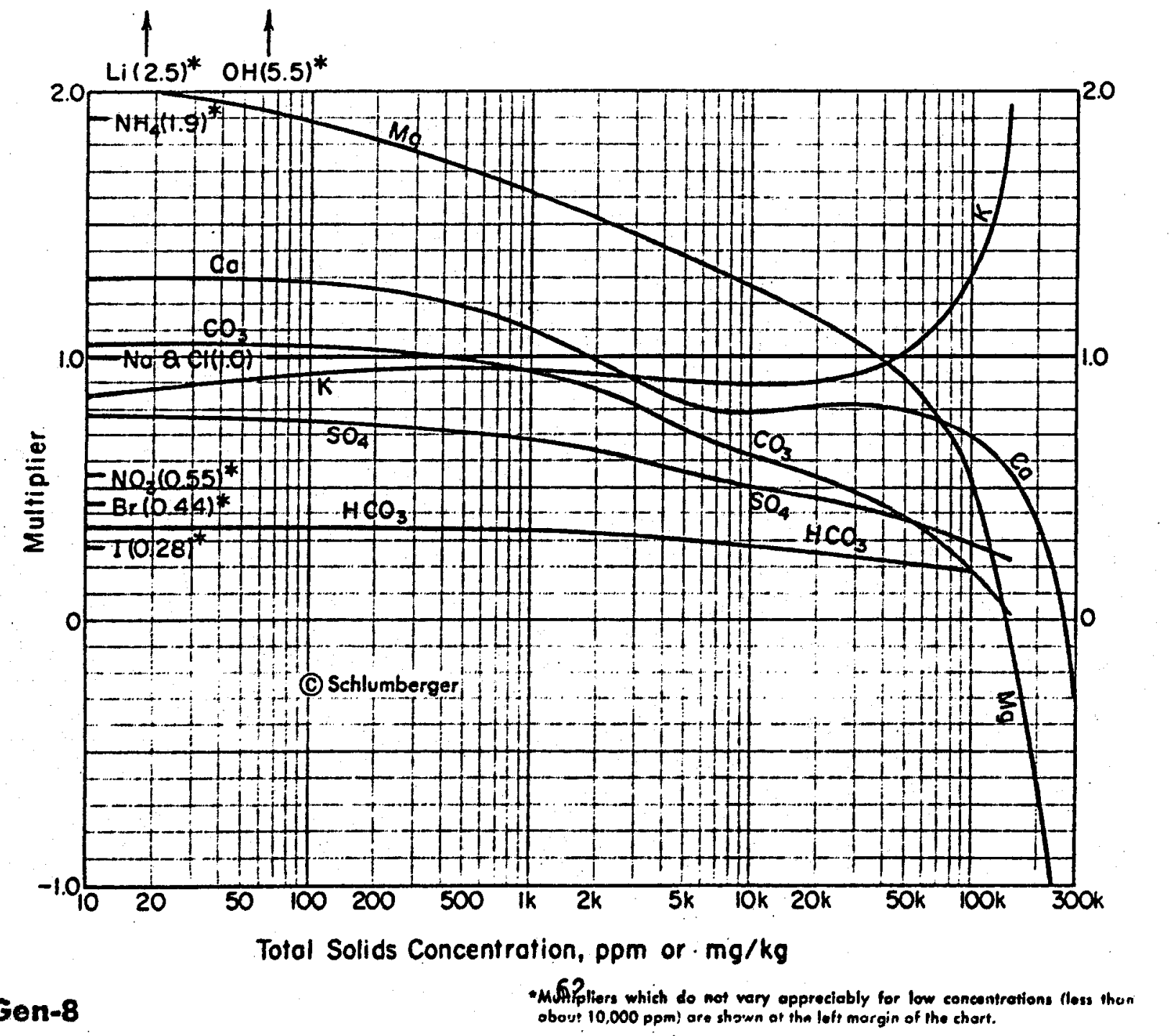




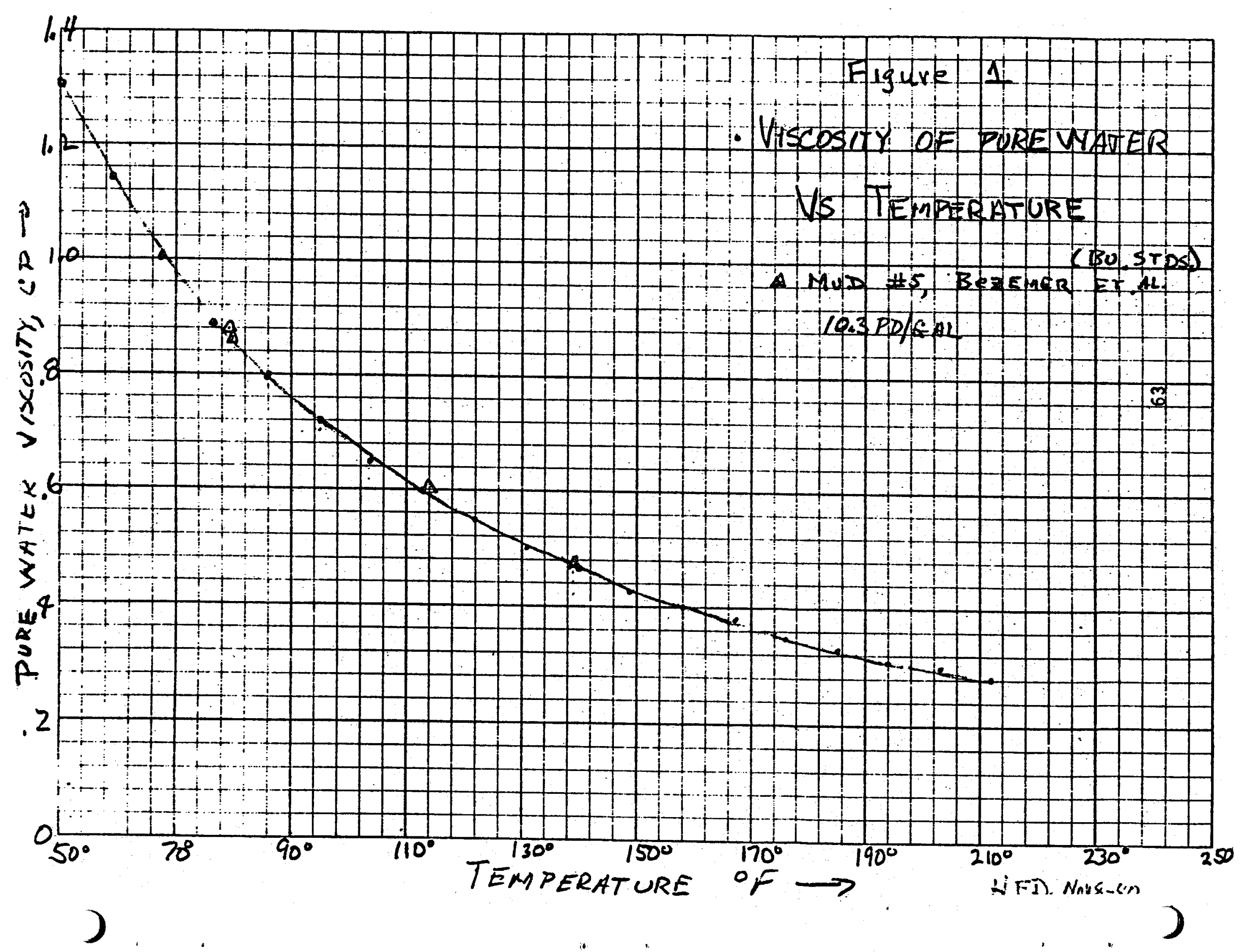


Progress Report \# 10, December 1980

Study of Log Derived Water Resistivity Data in Geopressured-Geothermal Formation:

We have carried out a lab experiment which shows pretty conclusively that we cannot explain the observed errors in calculated formation water salinity on the basis of viscosity induced errors in mud filtrate resistivity. A filter loss test carried out using a filter paper with a slit cut in it showed that the first filtrate caught was 14 times as viscous as the rest of the filtrate, yet there was little or no change in the resistivity! We tentatively explain this very surprising result on the basis of differences in micro and macro viscosity, with the resistivity a function of micro viscosity, and the measured viscosity (from flow through a capillary tube) a function of macro viscosity.

The best approach to getting good data now appears to be to abandon the resistivity measurement for the mud and mud filtrate, and measure the $\mathrm{Na}^{+}$ion directly using ion selective electrodes of the type developed by Orion Research Inc. We are encouraged by some preliminary results obtained using borrowed equipment. Tests on mud filtrates from laboratory muds show that directly measured $\mathrm{Na}^{+}$ion activity is 1.6 to 1.7 times greater than $\mathrm{Na}^{+}$ion activity inferred from resistivity measurements. This is in the right direction, and is nearly large enough an effect to account for the $100 \%$ errors in calculated formation water resistivity we have observed. We plan to continue to explore the use of ion selective electrodes for direct measurement of ionic activity in muds and filtrates. 


\section{DISCUSSION:}

We have carried out a crucial experiment which shows that the viscosity hypothesis we had formulated is not capable of explaining the errors we have encountered in calculating formation water resistivity from the SP. We carried out a standard filtrate loss test with type 1 low density mud using a filter paper with a $1 \mathrm{~cm}$ long slit in it made with a razor blade. The filtrate was caught in two batches--the loss in the first minute and the loss in the last 29 minutes were kept separate. Total loss was about $20 \mathrm{cc}$, with $9 \mathrm{cc}$ lost in the first minute. The viscosity of the first minute filtrate lost was $22.6 \mathrm{cp}$, as compared to $1.6 \mathrm{cp}$ for the last.29 minute sample. Surprisingly, the resistivities of these two samples of filtrate were about the same, 2.3 to $2.4 \Omega \mathrm{M} \odot 20^{\circ} \mathrm{C}$. The first filtrate sample caught undoubtedly contains more clay and other materials than the second sample, which accounts for the large viscosity ratio of 14 .

The very surprising result of essentially no change in resistivity accompanying this large change in viscosity may be explainable as follows. The resistivity is certainly affected by viscosity on the micro scale, since the mobility of the ions must be directly affected by the viscosity of the medium they move through. (See Figure 2 from Sixth Progress Report, August, 1980, showing how closely the resistivity vs temperature and viscosity vs temperature for brine solutions agree.) However, it may be possible for viscosity on the macro scale, as measured by flow through a capillary tube, for example, to be affected by a relatively few large molecules and clay particles, and still not affect the micro viscosity very much (as seen by ions in solution). This may be what is happening here. We plan to do some additional experiments with sugar and starch solutions to check this concept.

For whatever reason, however, the above experiment seems pretty conclusive in ruling out viscosity changes in the mud filtrate as a primary factor in explaining the error in calculating $R_{W}$ from the SP log. We now believe that the best approach is to measure the $\mathrm{Na}^{+}$ion activity directly in the mud filtrate, using a specific ion electrode of the type developed by Orion. This would avoid complications in relating ionic activity to resistivity, and would also measure directly the variable involved in the SH equation, 


$$
\text { S.S.P. }=K \log _{10} \frac{\mathrm{Na} \text { Ion Act. FW }}{\mathrm{Na} \text { ion Act. MF }} \ldots \ldots \ldots
$$

The equation usually used,

$$
\text { S.S.P. }=K \log _{10} \frac{\mathrm{RMFE}}{\mathrm{RWE}} \ldots \ldots \ldots \ldots
$$

assumes that the "effective" water and mud filtrate resistivities are inversely proportional to the respective $\mathrm{Na}^{+}$ion activities. If we measure the $\mathrm{Na}^{+}$ion activity in the filtrate directly, we no longer have to make this assumption, and can calculate the $\mathrm{Na}^{+}$ion activity in the formation water from equation (1). The calculated activity should lead directly to an "effective" water resistivity, Rwe, and thence to Rw (See charts SP 1 and SP 2, Schlumberger Chart book, reproduced here as Figures 1 and 2). This approach also automatically eliminates errors due to high $\mathrm{pH}$ muds, discussed in the last progress report.

We have made a few measurements on $\mathrm{Na}^{+}$ion activity in standard solutions of various $\mathrm{pH}$ values, and in mud filtrates from some of the standard muds we have made in the laboratory. Borrowed equipment was used in these tests.

Figure 3 shows $\mathrm{Na}^{+}$ion activity vs $\mathrm{ppm} \mathrm{Na}$ in solution using a range of $\mathrm{NaCl}$ brine solutions. The $\mathrm{pH} 6$ data was obtained using tap water, the $\mathrm{pH} 11+$ data was obtained by adding $\mathrm{NH}_{4} \mathrm{OH}$ to the various solutions. For interesting values of $\mathrm{Na}^{+}$ion concentration (above a few hundred $\mathrm{ppm}$ ) we see there is no affect of $\mathrm{pH}$ over this large range of $\mathrm{pH} 6$ to $11+$, which is a factor of $10^{5}$ in $\mathrm{OH}^{-}$ion concentration.

Figure 4 shows how $\mathrm{Na}^{+}$concentration in several mud filtrates as estimated from resistivity data relates to $\mathrm{Na}^{+}$ion concentration as estimated by the Orion $\mathrm{Na}$ electrode, and by atomic absorption analysis. (The last method includes not only ionic $\mathrm{Na}^{+}$, but all $\mathrm{Na}$, dissolved or undissolved, ionized or not ionized.) We see that in all cases the $\mathrm{Na}^{+}$ion concentration is least by the resistivity estimation. In the region above $2000 \mathrm{ppm} \mathrm{Na}^{+}$, the alternate methods give $\mathrm{Na}^{+}$ion concentrations that are 1.6 to 1.7 times as great as the estimate made from resistivity data. This is in the right direction to explain the usual error in calculated formation water salinity 
(calculated salinity too low), and is nearly as large a difference as some of the errors we have observed. We are encouraged by these inttial findings and will continue to explore use of $\mathrm{Na}^{+}$ion selective electrodes for our appication.

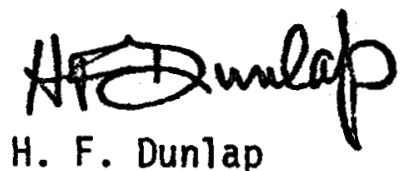




\section{$R_{\text {we }}$ DETERMINATION FROM THE SSP (CLEAN FORMATIONS)}

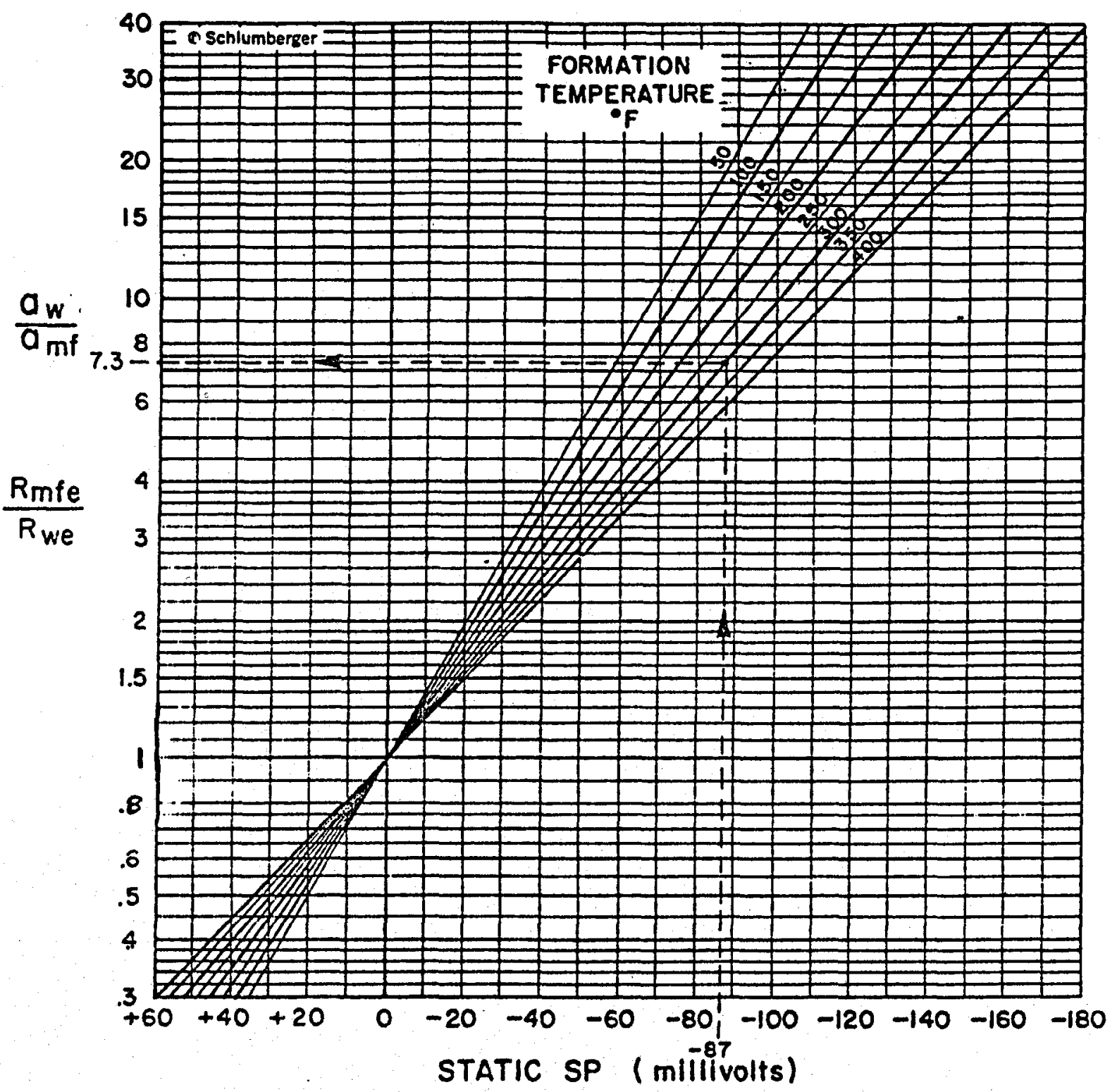

1. Preferably determine SSP from a thick, homogeneous bed using the shale base line from a good adjacent shale. If ucicssar\} correct the SP for bet thickness and invasion to set SSP (Chart SP-3). Determine formation temperature. (Chart Gen-6 may be used if necessary.)

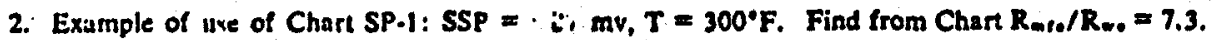

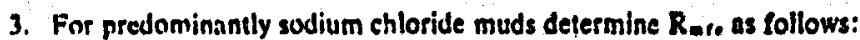

i. If $R_{m, \text { at }} 7^{\circ}$ is greater than 0.1 ohm-m, correct $R_{m,}$ to tormation temperature using Chart Gen-9, and use

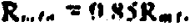

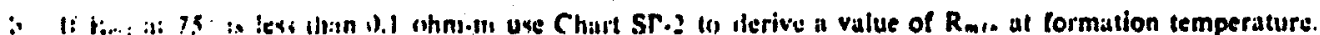

Fior other muds. see remisks on next page.

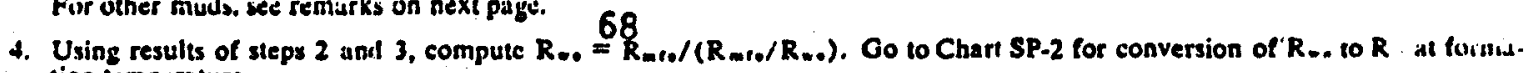
tion lemperature. 


\section{Figure $z$. \\ 6. \\ $R_{w}$ VERSUS $R_{w e}$ AND FORMATION TEMPERATURE $R_{m f}$ VERSUS $R_{m f e}$ FOR SALTY MUDS AND GYP.BASE MUDS}

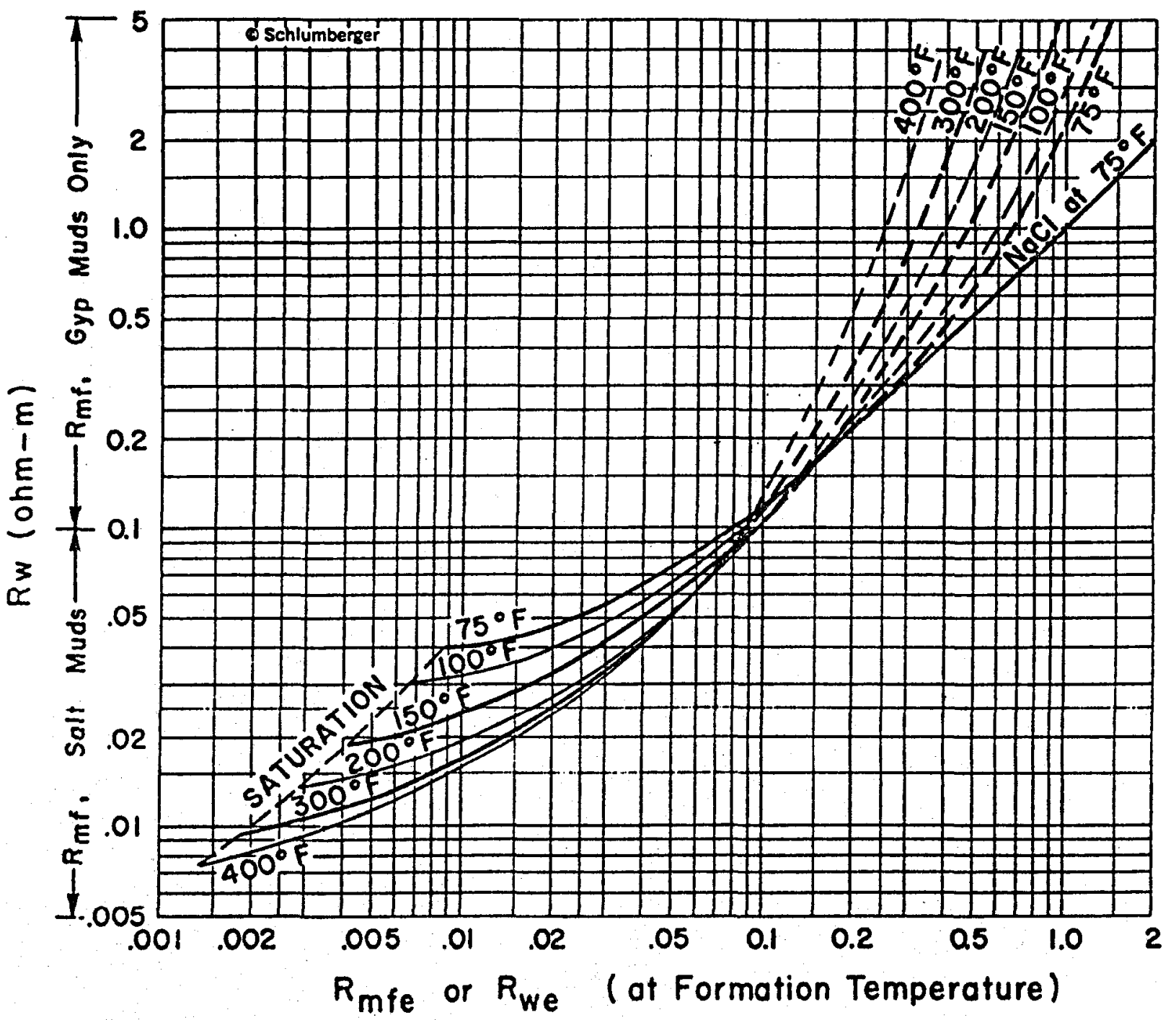

Use the solid lines of this chart for predominantly $\mathrm{NaCl}$ waters. The dashed lines are approximate for "average" fresh formation waters (where effects of salts other than $\mathrm{NaCl}$ becone significant). The dashed portions may also be used for gyp-base mud filtrates.

Example: $k_{w}=.025$ at $150^{\circ} \mathrm{F}$. From chart. $R_{w}=.037$.

Special prncedures for muds containing $\mathrm{Ca}$ or $\mathrm{Mg}$ in solution are discussed in the reference." Lime-base muds usually have a negligible amount of $\mathrm{Ca}$ in solution. and may be treated as regular mud types.

"Givendurin. M.. Tixier. M. P. and Simard. G. L..: "An Experimental Study on the Influence of the Chemical Composition of Electrolytes on the SP Curve," Journal foPetroleum .Technology. February. 1957. 


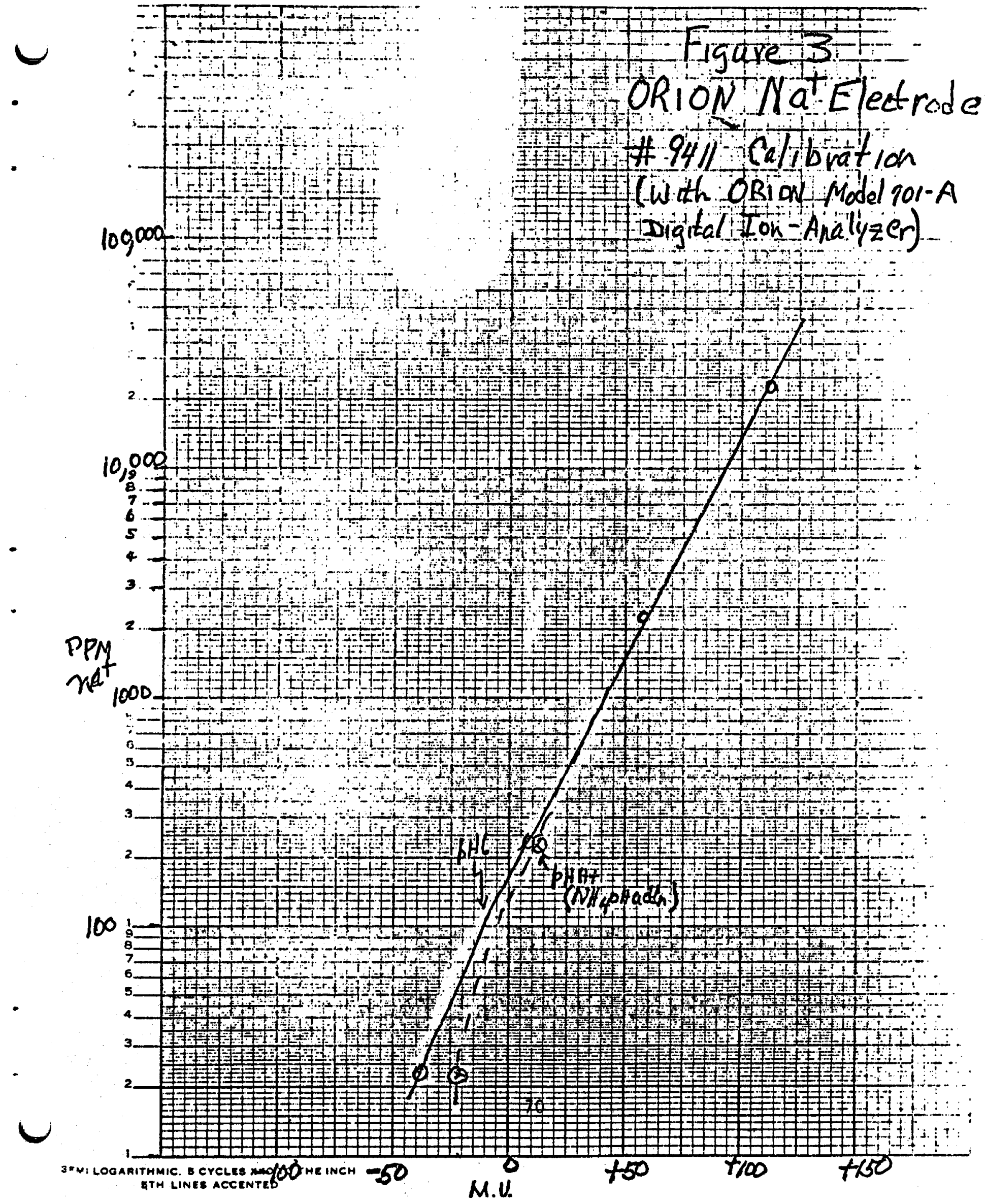




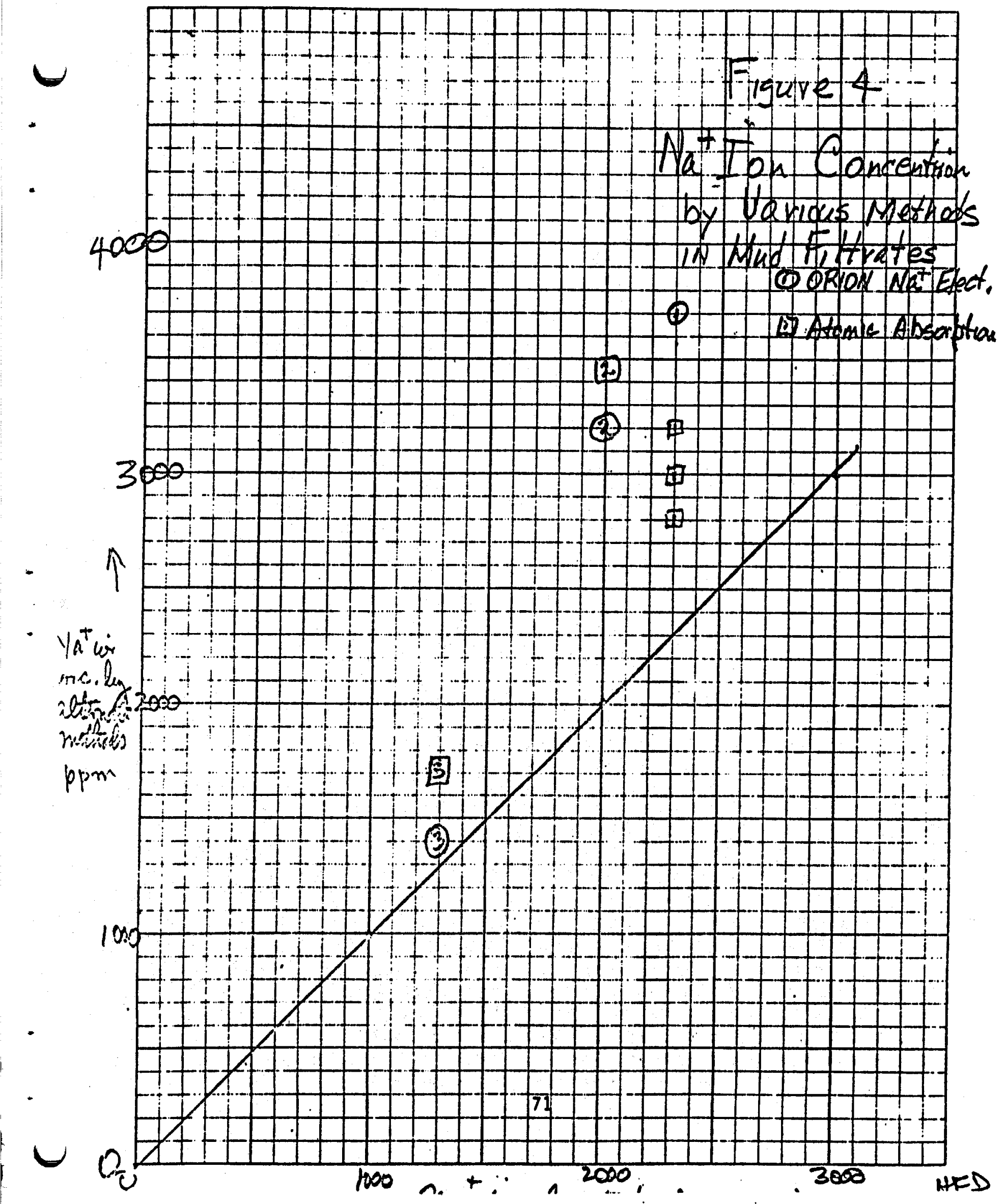




\section{PROGRESS REPORT \#11, JANUARY, 1981 \\ "STUDY OF LOG DERIVED WATER RESISTIVITY DATA}

IN GEO ${ }^{2}$ FORMATIONS"

SUMMARY: Experiments using viscous solutions made with Xanthan gum, a high molecular weight polymer, and with glycerol, a much rower molecular weight material, have been conducted. These support the hypothesis outlined last month - namely that high molecular weight viscofiers can affect the viscosity as measured by capillary flow without appreciably affecting the "micro viscosity" influencing the mobility of ions in solution, and therefore, without affecting solution resistivity.

Data have been obtained from Imco Services, a subsidiary of Halliburton, showing mud resistivity, temperature, and density measured continuously as the well is drilled. These are being analyzed at present and will be reported in detail later, but it is obvious that large variations in mud resistivity occur over fairly small time intervals.

We have developed a new concept which may explain some of our results. Overtreatment of muds with thinning agents, such as lignosulfonates, will lead to an excess of lignosulfonate in the mud, and therefore in the mud filtrate in the invaded zone. The lignosulfonate will tend to adsorb on the shales bounding the sand above and below. The hypothesis is that this adsorbed lignosulfonate (or other mud treating agent) will interfere with the $\mathrm{Na}^{+}$ion transport property of the shale, and therefore reduce the observed SP in the well opposite this sand. The lower observed SP would result in a lower calculated water salinity, in agreement with most of our data. If this hypothesis is correct, it would imply that not all lignosulfonate muds would show the reduced SP - just those which have been overtreated (perhaps the majority of muds).

To check this hypothesis we plan to carry out experiments similar to those reported by Mounce and Rust in 1944. They set up a doughnut shaped cell divided into 3 compartments by porous unglazed porcelain membranes. One compartment was filled with shale, one with salt water, and one with fresh water (representing the mud filtrate). We plan to check the effect on the cell potential of various mud components (such as lignosulfonate) when added to the fresh water section. If our hypothesis is correct, the cell potential would be substantially decreased when material is added that interferes with the ability of shale to transport the $\mathrm{Na}^{+}$ion. 
Rrogress Report \#11, January, 1981

Page 2.

We have built a cell and made some preliminary measurements but have no reliable data yet.

The lab work has been transferred from the Balcones Research Center, about 10 miles off campus, to the Petroleum Research Building on campus in order to improve work efficiency. We still have not received much of the equipment ordered last November 1st.

DISCUSSION: Following up on the hypothesis outlined last month, we have carried out experiments which support the idea that "macro viscosity," as measured in a capillary tube, can be quite different from "micro viscosity," as measured by ionic mobility. Viscosity of mixtures of Xanthan gum and water varying 14 fold as measured in a capillary viscometer showed no change in resistivity over this viscosity range. Glycerol-water mixtures with an equivalent viscosity variation were shown by our data to be accompanied by an 8 fold variation in resistivity. We attribute these results to the high molecular weight (about $10^{6}$ ) and small concentration of the Xanthan gum used (up to . $15 \%$ ), as compared to rather low molecular weight, (92) and large concentrations (up to $70 \%$ ), of glycerol used. The few, but large molecules of Xanthan affect the capillary viscosity, but do not appreciably interact with the ions. The much more numerous glycerol molecules can and do affect the ionic mobility, and hence the resistivity, as shown by the results in Figure 1.

We have obtained considerable data on the variation of mud resistivity in drilling wells from Imco Services, and from Anschutz Corporation, both at Houston, Texas. This involves data obtained by Imco's on site "Commander" service, which measures many variables continuously as the well is drilled, including mud weight, temperature, resistivity, etc. Data were obtained from 10 Gulf Coast wells, all using lignosulfonate muds. A typical plot of mud resistivity (corrected to $75^{\circ} \mathrm{F}$ ) vs. depth over about 1,000 feet distributed from 8,600 to $10,200 \mathrm{ft}$. in one of the wells (\#3) shows resistivity decreases erratically from about 3 SH to $1.75 \Omega M$ (about $42 \%$ ) while the mud density rises from 9.6 to $10.6 \mathrm{pds} / \mathrm{gal}$. See Figure 1. About 9 days were required to drill this interval, and no major mud changes were recorded. 
Progress Report \#11, January, 1981

Page 3.

It is obvious that a mud (or mud filtrate) resistivity measurement made at $10,200 \mathrm{ft}$. would be badly in error if used to represent the mud (or filtrate) in the hole when drilling the $8500 \rightarrow 9800 \mathrm{ft}$. interval in this well. We plan to analyze all of these wells to get an idea of the expected variation in mud resistivity.

A recent paper' giving salinity data comparison obtained from uphole and downhole mud resistivity measurements shows variations of $50 \%$ (down hole data saltier than up hole data after correcting for temperature difference). The authors do not explain the difference other than to say they are surprising. Such differences, if real, would obviously affect SP derived water resistivity.

The Anschutz Corporation has generously provided us complete data and logs on one of their deep, hot wells, the G. C. Cannan \#1, Brazoria County, Texas, T.D, 16030'. We hope to get considerable information from review of this well.

The experimental work has been moved from the Balcones Research Center, about 10 miles from the main University of Texas campus, to the Petroleum Engineering building on the main campus. It had become too inefficient to travel back and forth, especially for the half-time research assistant, who has to work an hour or two at a time, as dictated by his course schedule. We are pretty well set up in the new lab now, and obtained the data shown in Figure 1 at our new location.

A recent paper ${ }^{2}$ describing lignosulfonate action in "thinning" muds has led to a new concept which may explain the errors we have observed in calculating formation water resistivity from the S.P. Briefiy, the paper points out that many lignosulfonate muds are treated with an excess of this material. In such cases, the filtrate lost when sands are drilled (spurt loss) will contain excess lignosulfonate, which will tend to adsorb on the shales which bound the sands above and below. We speculate that this adsorbed layer will interfere with (decrease) the shale's ability to selectively transmit the $\mathrm{Na}^{+}$ion, and so reduce the observed S.P. If this does happen, it would cause us to calculate too fresh a formation water, in agreement with most of the data. We further speculate that the lignosulfonate will also reduce the ability of 
Progress Report \#11, January, 1981

Page 4.

membranes used in ion selective electrodes to transmit the chosen ion, so that $\mathrm{Na}^{+}$activity measurements of the mud filtrate may still give a good measure of a mud filtrate property which can be used to calculate correct formation water resistivity from the SP.

To check this hypothesis we plan to set up a doughnut shaped cell of the type used by Mounce et. al. in their classic experiment reported in $1944 .^{3}$ (See Figure 3, which includes a sketch of Mounce's cel1.) We will test our hypothesis by measuring the effect of various mud additives such as lignosulfonate to the fresh water portion of this cell. We have made some preliminary measurements using a cell we have constructed, but have no reliable data to report as yet. We are having trouble with electrode drift.

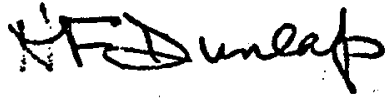

H. F. Dunlap, February 9, 1981

\section{References:}

(1) L. H. Robinson Jr. et. al., "Exxon MWD Tools Yield Unexpected Downhole Data," Oil and Gas Journa1, April 21, 1980, pp. 86-95.

(2) R. V. Lauzon et. al., "Zeta Potential Can Help Optimize Lignosulfonate Treatment," $0 i 1$ and Gas Journal, January 26, 1981, pp. 188-202.

(3) W. D. Mounce et. al., "Natural Potentials in Well Logging," Trans. AIME, Volume 155, 1944, pp. 49-57. 


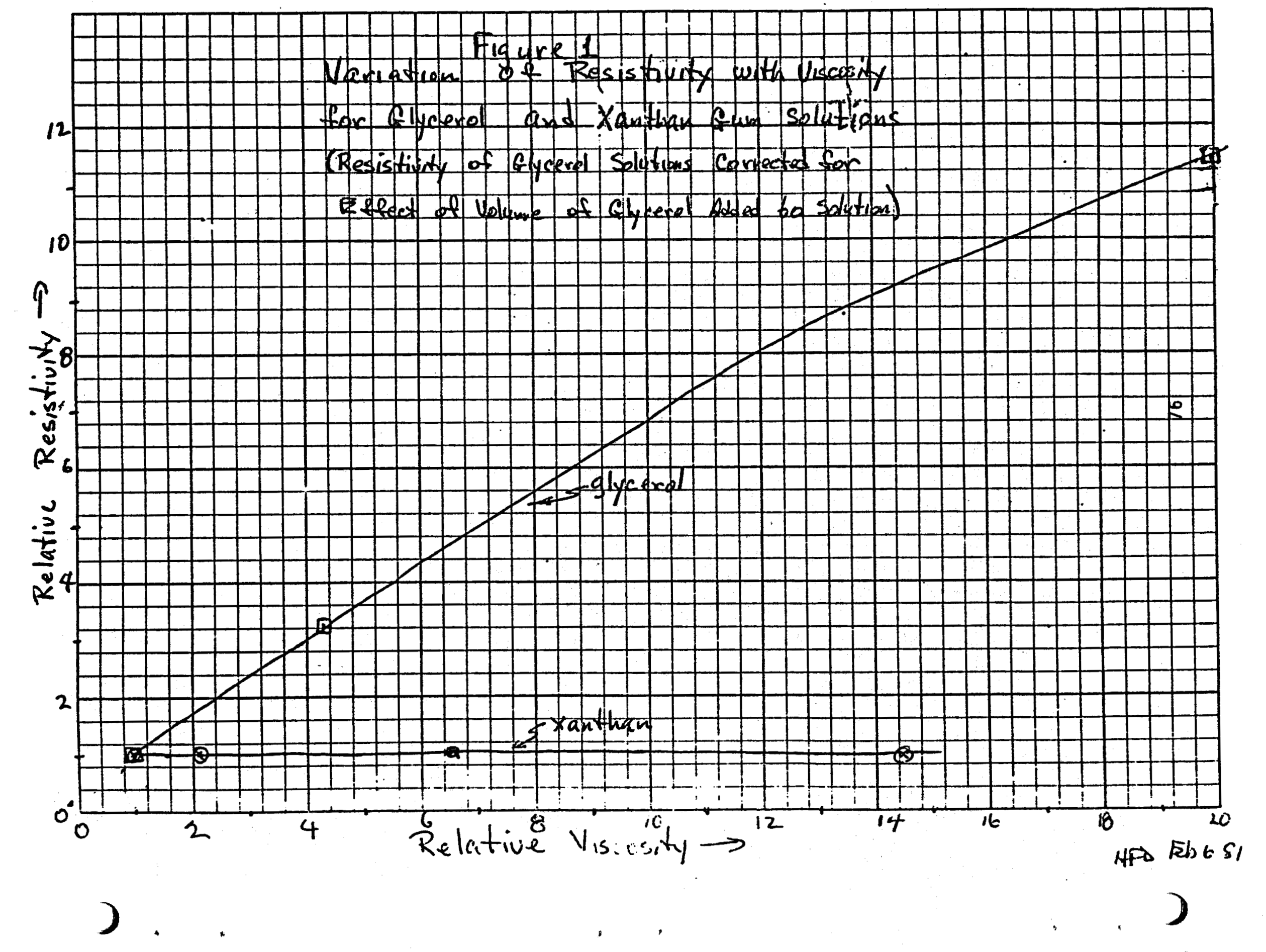




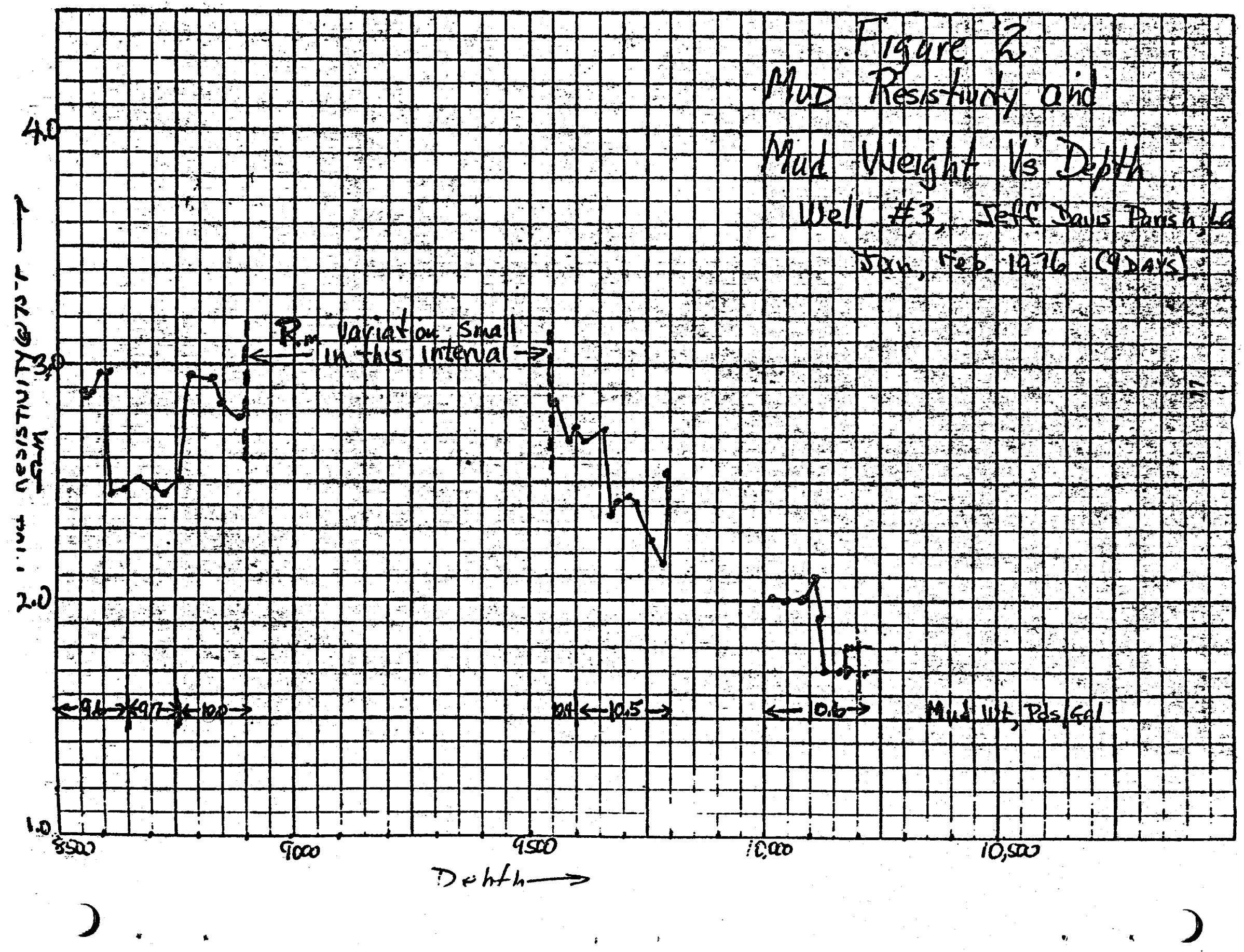




\section{Figuve 3 \\ Cell for Modeling S.P. Potentials}

W. D. KOUNCE AND W. M. RUST, JR.

section is flled with shale. Section I is filled illustrated. If the water in the sand is more with fresh water. Section II is filled with. salt water. The two sections are separated by a permeable membrane. Current flows

saline than the mud, current will flow from the shale into the drilling mud. Fig. 1c illustrates the corresponding potential log.

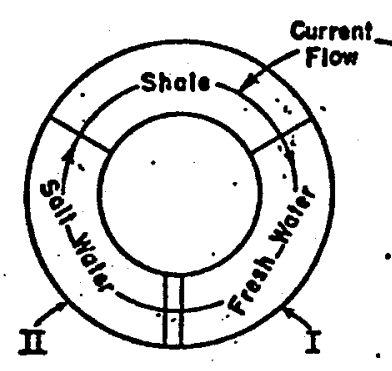

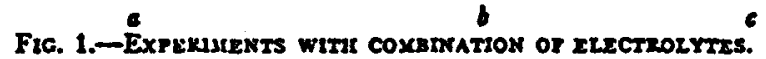

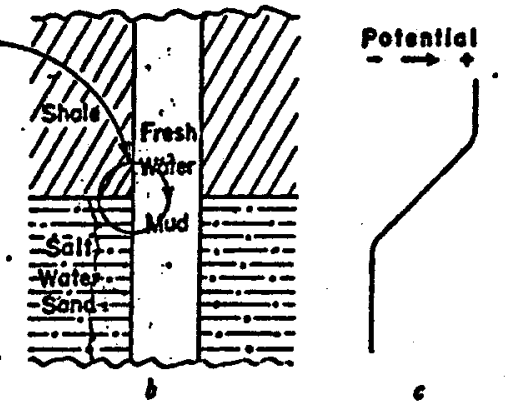

in the direction from section $I$ to section $I I$. Fif both sections were flled with fresh or Woth with salt witer of equal concentration, fo. current would flow: If section I were

Fig. le shows that if the mud is more saline than the water in the sand, the direction of current flow will be reversed and as a result the potential log will be

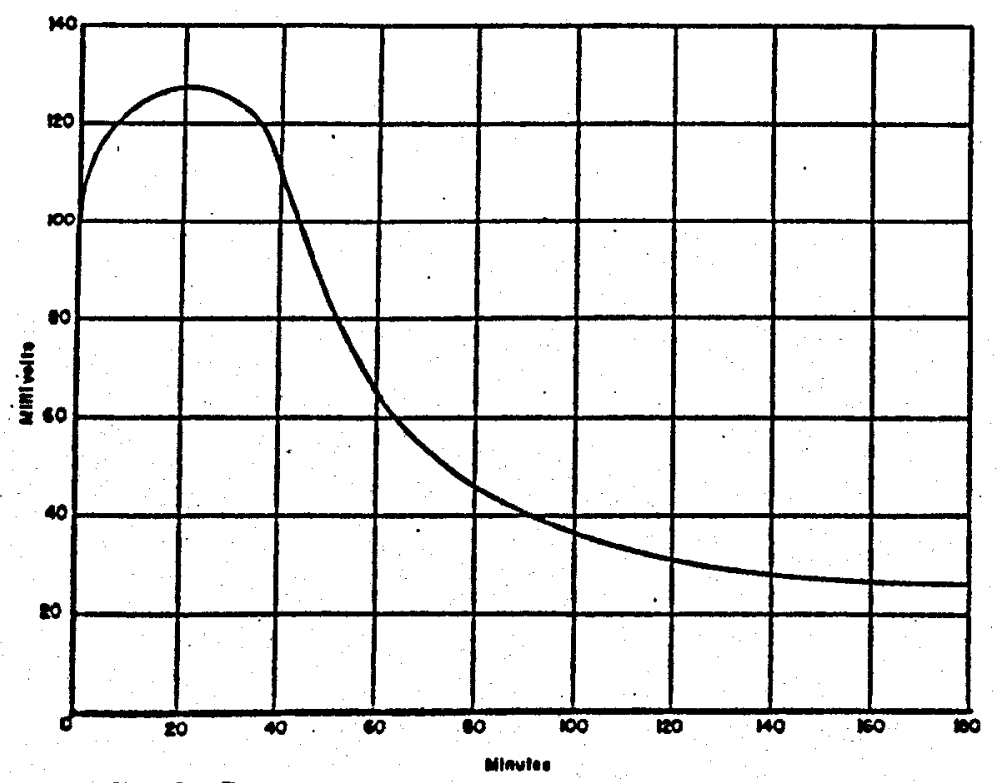

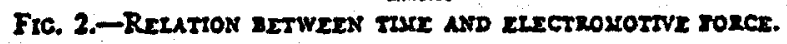

5ifj with salt water and section II were Wist with fresh water, the direction of curHow would be reversed. In Fig. $1 b$, the reversed. A case has been observed where ordinary tannate mud was replaced by silicate mud after the well had reached a Haslogous situation as it exists in a well is cousiderable depth and after preliminary

$$
\text { Trans. AIME, vol. 155, } 1944 .
$$


PROGRESS REPORT \# 12, February, 1981

\section{"STUDY OF LOG DERIVED WATER RESISTIVITY DATA}

IN GEO ${ }^{2}$ FORMATIONS"

SUMMARY: We have obtained some lab measurements of shale membrane potential using fresh lower Cretaceous shale from a well in SE Montana at about $1300^{\prime}$. All attempts to use "synthetic" shales made in the lab were unsuccessful, apparently due to the lack of compaction. Lignosulfonate additions to the fresh water portion of the cell did not affect the shale potential. This does not support the "lignosulfonate overtreatment" hypothesis advanced last month (Progress Report \#11). We will attempt to get other shales for testing of this hypothesis in the lab.

At the request of Mr. Keith Westhusing, I have calculated the salinity for two zones in the F. A. Godchaux III \# 1 well using the SP (curve); and the $R_{W a}$ (sonic) methods. The salinity appears to be well over 100,000 ppm $\mathrm{NaCl}$ in both zones. (See attached letter to Westhusing dated February 26, 1981). Figure 1 attached to this letter shows an empirical salinity correction curve I recently plotted which is quite interesting. The calculated salinity values using the "curve" method fall into two groups, shown in Figure 1, as the upper and lower branches of the "curve" data. What is interesting is the wide separation of the branches, combined with the good grouping of points along each branch. All the points on the lower branch have mud weights $>15.9 \mathrm{ppg}$ and well temperatures $>260^{\circ} \mathrm{F}$. Except for point (12), all the points on the upper branch fail to meet one or both of these conditions. On the upper branch, six of the wells are from Louisiana and four are from Texas. On the lower branch, all five are from Texas. The two branches may reflect geologic age. We will investigate this further.

We have plotted up some of the Imco data showing continuous measurement of mud resistivity, mud weight, etc. in a number of drilling wells (See Figures 4-13). These data show a wide short term variation in mud resistivity (100\% or more), combined with a general trend to decreasing mud resistivity with well depth after correcting for temperature effects. The general trend implies that the mud filtrate will tend to be fresher than the mud at time of logging which would tend to reduce the observed.S.P. This effect would be superimposed on the erratic short term variation of 
mud resistivity, which might lead to increased or decreased observed S.P. Overall, the situation is very complicated, and the outlook for accurate calculation of water resistivity from the S.P. is poor if mud resistivity variations of the magnitude shown by the Imco data are common.

\section{Discussion:}

Work with the doughnut shaped cell described in last month's progress report (Figure 3, Progress Report 11) has continued. All attempts to obtain a stable voltage reading with lead electrodes were unsuccessful, the slightest scratch or scrape of the surface creating new drift even after the electrodes were aged for days. We have used Orion single junction reference electrodes Model 90-01 with some success. These diffuse $\mathrm{KCl}$ slowly through a porous membrane to establish contact with the solution. Since the $\mathrm{K}^{+}$and $\mathrm{Cl}^{-}$ions diffuse at about the same rate, very little liquid junction potential should develop at the electrode. These seem stable to one or two M.V. over a few hours. However, long term polarization of the electrodes (as much as 15 MV) can apparently occur, as measured when both electrodes are placed in a beaker of tap water. All such long term polarization effects have been subtracted out of the data shown in Figure 2, which gives the open circuit voltage observed across a shale membrane* for about a week. The voltage was measured using the Orion 90-01 reference electrodes and a Simpson Model 313 solid state voltmeter with an internal impedance of 11 megohms. The voltage rises to its initial value of around 37 or $38 \mathrm{mv}$ rather quickly (in less than 15 minutes after filling the cell) and decays slowly as shown. At about 149 hours both the fresh and salt water solutions were replaced, as there appeared to have been some evaporation. The fresh solutions caused a short term rise in voltage, but by the following day (172 hours) the voltage was apparently declining as before.

A comparison of a similar (a few inches deeper along core) shale membrane's behavior with that of the Orion \# 94-11 Na electrode behavior as the salinity contrast across the membrane is varied is shown in figure 3 . Presumably the Orion $\mathrm{Na}$ electrode has fairly good $\mathrm{Na}^{+}$ion transport properties ( $54 \mathrm{mv} /$ decade salinity change vs $59 \mathrm{mv} /$ decade for a perfect membrane). We see that our shale membrane is only about half as efficient as the Orion membrane. Also, the shale membrane saturates rather badly at high salinities. This is not too surprising since the Orion solid state $\mathrm{Na}$ electrode is carefully engineered to selectively transpart the $\mathrm{Na}^{+}$ion. *This membrane was cut from a fresh shale core obtained from a well in S.E. Montana, 1370". lower Cretaceous in age. All attempts to make "synthetic" shales in the lab using bentonite, inert clay, and various salinity brines were failures. 
We tested the hypothesis outlined last month - i.e. - that an excess of lignosulfonate in the mud and or mud filtrate would interfere with the $\mathrm{Na}^{+}$ ion transport ability of the shale, thereby reducing the observed S.P. With the shale membrane cell set up with solution salinities of $1000 \mathrm{ppm}$ and $100,000 \mathrm{ppm}, .57 \%$ of Spersene (chrome lignosulfonate) was added to the $1000 \mathrm{ppm}$ solutions. This is equivalent to about $2 \mathrm{pds} / \mathrm{bbl}$ of mud. No change in cell potential was observed. This result casts some doubt on the validity of the hypothesis. We hope to obtain other shales and repeat the test, however.

$\mathrm{Mr}$. Keith Westhusing requested that we calculate water salinity in sands A e 15450-16,000 ft and B o 14900-15275 ft in the F. A. Godchaux III \# 1 well, Vermilion Parish, Louisiana. We did this using both the SP (curve) method and the $R_{\text {wa }}$ (sonic) method. See attached letter to Westhusing dated February 26 for details. Figure 1, which is referred to in the letter, deserves some additional comment. The good grouping of points on the upper and lower branches of the "curve" data strongly implies some underlying reason for this behavior. The separation into high temperature $\left(>260^{\circ} \mathrm{F}\right)$, and dense mud (> $15.9 \mathrm{ppg}$ ) wells for the lower branch, and all nther wells into the upper branch does not work all the time, since test \#12 (Exxon Armstrong \#46), which has a mud weight of $17.9 \mathrm{ppg}$ and a well temperature of $304^{\circ} \mathrm{F}$, falls very nicely on the upper rather than the lower branch of the curve. The best idea that I have at present is that the difference may be related to geologic age. The upper branch of the curve contains all the Louisiana wells, and the Texas wells on the upper branch have a shallower average depth than the Texas wells on the lower branch; $12,250 \mathrm{ft}$ vs. $14,340 \mathrm{ft}$. Note that all the wells on the lower branch of the curve are from Texas, and these wells should be geologically older than the wells at equal depth in Louisiana. I hope to be able to get more accurate estimates of formation age on all these tests to follow up on this idea. Whatever the reason, the correlation shown in Figure 1 looks pretty good, and if we can get a reliable method to assign tests to the upper or lower branch of this correlation, we should improve the accuracy of the salinity estimate considerably.

Note that both the upper and lower branches of the correlation seem to converge at about 50,000 ppri calculated salinity for $0 \mathrm{ppm}$ true salinity. This would imply negative true salinity for calculated salinities 
$<50,000 \mathrm{ppm}$, which is, of course, impossibie. What must happen is tnat soth the upper and lower branches of the correlation should rise sharply =rom the origin as true salinity rises from 0 to $10,000 \mathrm{ppm}$.

Work on the Imco data showing continuously measured values of mud -esistivity, mud weight, etc. in a number of recent Gulf coast wells arilled with lignosulfonate muds has been both illuminating and discouraging. we see from Figures $4-13$ that the short term variations in mud resistivity sre large ( $100 \%$ or more), that they do not always correlate with changes in ᄀud weight, and that there is a significant trend in most wells for mud resistivity corrected to $75^{\circ} \mathrm{F}$ to decrease with depth. Finally, the value of mud resistivity as reported by Imco was checked in several wells against the header value of $R_{m}$ corrected to $75^{\circ}$ as shown on the electric $\log$ (See Figures $7,9,10,12$ ). We see that these do not always agree.

All of the above operate to make accurate calculation of the formation weter salinity from the SP log very difficult, if not impossible, particularly if the mud resistivity history as the well is drilled is not available. This data is almost never available - and using it if it were available would not be easy. The trouble is that if there is a significant variation in mud salinity between the time the well is drilled and the time it is logged, then the mud filtrate in the invaded zone will have a different salinity than the mud in the hole, and two electrochemical shale cells will be set up - one corresponding to the salinity contrast between the mud and the formation water, the other corresponding to the salinity contrast between the mud filtrate in the invaded zone and the formation water. These may create a smaller SP (as when the mud filtrate is fresher than the mud) or a greater SP (when the mud is fresher than the mud filtrate). The magnitude of the correction would be difficuit to estimate accurately, but the changes in S.P. should be quite significant for the changes in mud resistivity shown in Figures $4-13$.

When drilling new wells, one obvious conclusion is to change mud resistivity (and salinity) as little as possible between logging runs. Monitoring the mud resistivity continuously is needed to be sure that this is done. Finally, the differences sometimes seen between log header values of $R_{m}$ at a given depth and the Imco values of $R_{m}$ at the same depth require that one of these is wrong. If the header value is wrong, then calculations made using the "curve". approach will also be wrong, since this approach assumes that the header value of $R_{m}$ is correct. The inference is that we should be very careful (obtain multiple mud samples for measurement) in getting the $R_{m}$ value entered on the $\log$ header. 


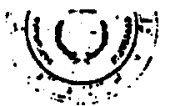

THI: L'NIVERSITY OF TEXAS AT AUSTIN

DEPARTAIENT OF PETROIEUM ENGINEERING

AUSTIN. TEXAS 78712

Petroleum Enginesring Buolding 211

Arear Codes12 \$71.3161

February 26, 1981

Mr. Keith Westhusing, Director

Geopressure Projects office

Suite 8620, Federal Bldg.

515 Rust St.

Houston, Texas 77002

Dear Keith:

In reply to your letter of Feb. 14, 1981 concerning water salinity calculations in the F. A. Godchaux III "II well, I have calculated the formation water salinity by several methods in sand A, from 15450-16000 ft, and sand $B$, from 14900-15275 $\mathrm{ft}$. The results and detalls of the calculation, are shown in the attached appendix. I belleve that the water salinity in both sands is greater than $100,000 \mathrm{ppm}$, and that a "best estimate" of the salinity from data avallable at present would be $140,000 \mathrm{ppm}$ for sand A and $115,000 \mathrm{ppm}$ for sand $B$, bised on SP calculations. Calculations from the sonic log. ( $R$ wa method) lead to substantially higher salinities, $130,000 \mathrm{ppm}$ for sand $A$, and $160,000 \mathrm{ppm}$ for sand $B$, but these are not very reliable due to the uncertain compaction factor correction, $C_{p}$, which must be used to obtain correct porosity values from the sonic log.

I have discussed the S.P. calculations with Ray Gregory and his associates at the Bureau of Economic Geology, and I believe we are in basic agreement on this calculation. There is an unresolved temperature difference between us which accounts for some of the difference in salinity results. He chose to interpolate linearly between an assumed $70^{\circ} \mathrm{F}$ surface temperature and well temperature at T.D. to get uphole temperatures at various depths. I chose to use a temperature gradient of $2.4^{\circ} \mathrm{F} / 100 \mathrm{ft}$. at depth to calculate temperatures in the neighborhood of T.D. Th1s gradient cones from temperatures measured in the Exxon Fee $\| 80$ well (also in Vermilion Parish) at depths of 13984 to $15960 \mathrm{ft}$. The best way to get the uphole temperatures in the Godchaux well would be to obtain a temperature gradient for this well, using temperature and depth from the next shallower logging run, but these data were not sent to efther Gregory or me. Gregory also did not have the sonic log data, and so did not calculate the Rwa values and equivalent salinities.

In obtaining the "best estimate" SP derived values I used the "curve" method where the mud filtrate resistivity is calculated from the measured mud resistivity using the $K_{F}$ factor for lignosulfonate muds read from Figure 1 of my Sixth Progress Report (August 1980). The results are then further corrected by using a second, salinity correction curve, attached to this letter as Figure 1, which allows for the effect of formation water salinity. This is a curve 1 have only recently plotted, and is strictly empirical, but the data does seem to fall rather well into two groups-defining an upper line where nearly all the points are for wells with temperatures $<260^{\circ} \mathrm{F}$ and mud 
weights < 15.9 p.p.g., and a lower line where all the points are for wells with temperatures $>260^{\circ} \mathrm{F}$ and mud weights $>15.9 \mathrm{ppg}$. Only wells with lignosulfonate muds are shown. Calculated salinity values for both "header" data (RMF value read from $\log$ header) and "Curve" data (RMF value calculated from KF curve, 6th Progress Report, August 1980) are shown on this figure. We see that calculations using header data apparently give too low a calculated water salinity for salinities $>$ about $40,000 \mathrm{ppm}$, and too high a calculated salinity for salinities lower than this. The lower branch of the "curve" calculated salinity gives too low a value of salinity for salinities > about $70,000 \mathrm{ppm}$, and the upper branch of "curve" calculated salinity data gives too high a calculated value for all salinities < about $200,000 \mathrm{ppm}$. The Godchaux well data puts us on the upper branch of curve (mud wt. $17.8 \mathrm{pd}$ gal, well above the $15.9 \mathrm{ppg}$. Iimit, but well temperature for sand $A=259^{\circ} \mathrm{F}$ and for sand $B=247^{\circ} \mathrm{F}$, which are both below the $260^{\circ} \mathrm{F}$ limit). In making this salinity correction for sand A, for example, I entered the value of $160,000 \mathrm{ppm}$ obtained. from the "curve" calculation on the ordinate, and read the true value of salinity from the abcissa as $140,000 \mathrm{ppm}$, using the upper branch of the "curve" data. The "curve" value calculated for sand B was $140,000 \mathrm{ppm}$, which leads to 115,000 ppm true salinity, again using the upper branch of "curve" salinity correction.

At the moment I have no idea why the salinity correction shown in Figure 1 , works as it appears to - it is purely empirical. However, the grouping of points is consistentenough to make me believe that the effect is real.

In summary, I don't think that the formation water in these two sands could be as low as $75,000 \mathrm{ppm}$. The best estimate I can make is $140,000 \mathrm{ppm}$ for sand $A$, and $115,000 \mathrm{ppm}$ for sand $B$.

$$
\begin{aligned}
& \text { sincerely, } \\
& \text { H. F. Duniap }
\end{aligned}
$$

$\mathrm{HFD} / \mathrm{sma}$

Enclosures

cc: Dr. Dorfman and Ray Gregory 


\section{Appendix: Details of Calculation}

\section{SP Method}

F. A. Godchaux III 1 Well, Vermilion Parish, La. Sands A (15450'-15980') and $B\left(14900^{\prime}-15275^{\prime}\right)$ Lignosulfonate mud, 17.8 p.p.8.; Header value of $R_{M}=.534$ @ $68^{\circ} \mathrm{F} ; R_{\text {IF }}=.229$ e $70^{\circ} \mathrm{F}$. Well temp. C T.D. of $16000^{\prime}=271^{\circ} \mathrm{F}$. S.P. In upper, " $B$ " sand - $20 \mathrm{MV}$ (note shale base line drift here) and in lower, "A" sand, SP = $32 \mathrm{MV}$. Take geothermal gradient from Exxon Fee 80 well (Test 17 in progress reports), also in Vermilion Par1sh, where there are well temperatures of $285^{\circ} \mathrm{F}$ ○ 15690 and $244^{\circ} \mathrm{F}$ C $13984 \mathrm{ft}$., leading to a temp. gradient at depth of $2.4^{\circ} \mathrm{F} / 100 \mathrm{ft}$. This gives a well temperature in Godchaux well e $15000 \mathrm{Ft}$. (Sand B) of $247^{\circ} \mathrm{F}$, and E 15,500 ft. (Sand A) of $259^{\circ} \mathrm{F}$.

Consider Sand "A": R MF Header $=.229 \odot 70^{\circ} \mathrm{F}=.0663 \odot 259^{\circ}$;

$R_{\text {IFE Header }}=.85(.0663)=.056 \Omega \mathrm{M} \odot 259^{\circ}$

$R_{W E \text { Header }}=.056 / 2.1=.027 \Omega M \odot 259^{\circ}$ (From SP-1, Schl. Chart Book, 172ed.)

$R_{W \text { Header }}=.030 \Omega$ S $259^{\circ}$ (From SP-2, Schl. Chart Book, 72 ed.)

Salinity (Header) $=76,000$ ppm (From Gen-9, Schl. Chart Book, '72 ed.)

$K_{F}=.15$ (From Fig 1, Sixth Progress Report, Aug, 1980)

$R_{\text {IF }}$ Curve $=.15(.151)=.023 \Omega \mathrm{M} C 259^{\circ} ; R_{\text {MFECurve }}=.85(.023)=.020 \Omega \mathrm{M}$

$R_{\text {WE }}$ Curve $=.02 / 2.1=.0093 \Omega M @ 259^{\circ} \mathrm{F}$ (From Sp-1, Schl. Chart Book)

$R_{W}$ Curve $=.017 \Omega M @ 259^{\circ} \mathrm{F}$ (From SP-2, Sch1. Chart Book)

Salinity Curve $=160,000$ ppm (From Gen-9, Schl. Chart Book)

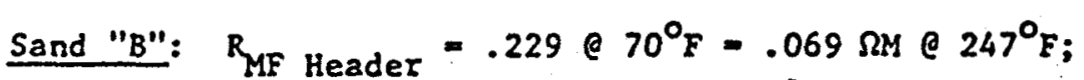

$R_{\text {MFE Header }}=.85(.069)=.059 \Omega \mathrm{M} C 247^{\circ} \mathrm{F}$

$R_{W E \text { Header }}=.059 / 1.64=.036 \Omega \mathrm{M}$ e $247^{\circ} \mathrm{F}$ (From SP-1)

$R_{W \text { Header }}=.037 \Omega M \subset 247^{\circ} \mathrm{F}$ (From SP-2)

Salinity (Header) $=66,000 \mathrm{ppm}$ (From Gen-9)

$K_{F}=.15$ (From F18 1, Sixch Progress Report, Aug, 1980)

$R_{\text {IF Curve }}=.15(.158)=.0237 \Omega \mathrm{M}$ e $247^{\circ} \mathrm{F}$; R RE Curve $=.85(.0237)=$ .020 Sa1 e $247^{\circ} \mathrm{F}$;

$R_{\text {WE curve }}=.020 / 1.64=.012 \Omega M$ \& $247^{\circ} \mathrm{F}$ (From SP-1)

$R_{W}$ curve $=.019 \Omega M$ e $247^{\circ} \mathrm{F}$ (From SP-2)

Salinity (Curve) $=142,000 \mathrm{ppm}$ (From Gen-9) 
What shall we use for $C_{p}=$ compaction factor, to correct for overestimation of porosity by sonic $\log _{\text {? }}$ B 18 uncertainty here. At shale considerably $>100 \mu \mathrm{s} / \mathrm{ft}$. , Indicating need for $C_{p}>1.0$. At $14,900 \mathrm{ft}$. and higher $\Delta t$ shale $=130 \mu \mathrm{s} / \mathrm{ft}$; ; at greater depths $\Delta t$ shale slightly less $\approx 122 \mu \mathrm{s} / \mathrm{ft}$. C 15420-50 ft. for example. Assume $F=.81 / \phi^{2} ; \Delta t_{\operatorname{matrix}}=55.5 \mathrm{us} / \mathrm{ft}$. , and make calculation for $c_{p}=1.0 ; 1.1 ; 1.2 ; 1.3$.

Sand A: $\Delta t$ sand varies from $90-100 \mu \mathrm{s} / \mathrm{ft} .$, use $95 \mu \mathrm{s} / \mathrm{ft}$. From Schlumberger chart POR-3, we have porosities of: $\phi=29.5 \%$ if $C_{p}=1.0 ; \phi=27 \%$ if $c_{p}=1.1$; $\phi=24.5 \%$. If $c_{p}=1.2$ and $\phi=22.5 \%$ if $c_{p}=1.3$. Corresponding formation factors (from Schlumberger Chart POR-1) are $F=9.31 ; 11.1 ; 13.5$; and 16.0 . The value of $R_{0}$ from deep induction $l 0 g$ is about $.17 \Omega$. (See sand streaks $C$ $15512-20 ; 15632-42 ; 15720 ; 15785-94 ;$ and $15930-36)$. For an $R_{0}$ of .17 $\Omega \mathrm{M}$ and $F$ values as given above we get $R_{\text {wa }}=R_{0} / F$ values $C 259^{\circ} \mathrm{F}$ of : $C_{p}=1.0$, $R_{w a}=.0183 \Omega M ; C_{p}=1.1, R_{w a}=.015 \Omega M ; C_{p}=1.2, R_{w a}=.0226 ; C_{p}=1.3$, $R_{w a}=.0106 \Omega M$. These values of $R_{w a}$ correspond to salinity values (using Gen-9) of: $140,000 \mathrm{ppm} ; 180,000 \mathrm{ppm} ; 250,000 \mathrm{ppm}$, and $>300,000 \mathrm{ppm}$ respectively.

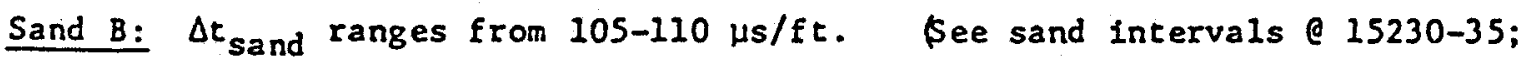
$\left.15020 ; 1493-4-43^{\prime}\right)$.: Assume $\Delta t_{\text {sand }}=107 \mu s / f t ; R_{0} \approx .14 \Omega \mathrm{M}$, Temp. $-247^{\circ} \mathrm{F}$. Proceeding as for sand $A$, we find for various assumed values of $C_{p}$ :

\begin{tabular}{lllll}
$C_{p}$ & $\phi$ & $F$ & $R_{w a}$ & Salinity $(\mathrm{ppm})$ \\
\hline 1.0 & 38.5 & 5.5 & .026 & 95,000 \\
1.1 & 35 & 6.3 & .022 & 120,000 \\
1.2 & 32 & 8.0 & .0175 & 160,000 \\
1.3 & 29.5 & 9.3 & .015 & 200,000
\end{tabular}

We are falrly sure we need some $C_{p}$ value greater than 1.0 in view of the large $\Delta t$ shale values. Also, use of small $c_{p}$ values of 1.0 and 1.1 leads to unreasonably high porosities in sand $B$. These considerations lead us to a rather uncertain "best estimate" of salinity for Sand $A: C_{p}=1.1, \phi=27 \%$; salinity $=180,000 \mathrm{ppm}$ and for Sand $B: C_{p}=1.2, \phi=32 \%$; salinity $=160,000 \mathrm{ppm}$. 


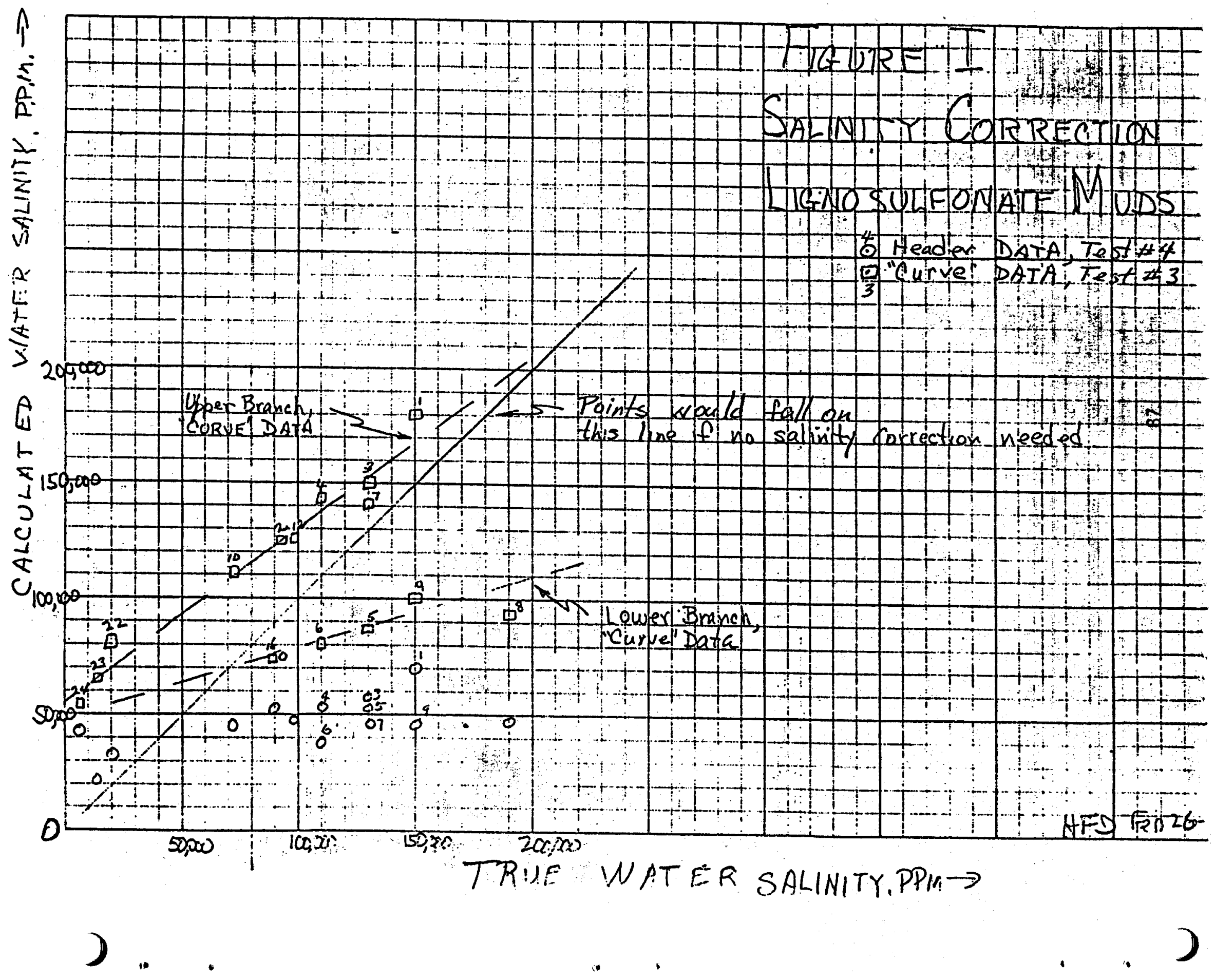




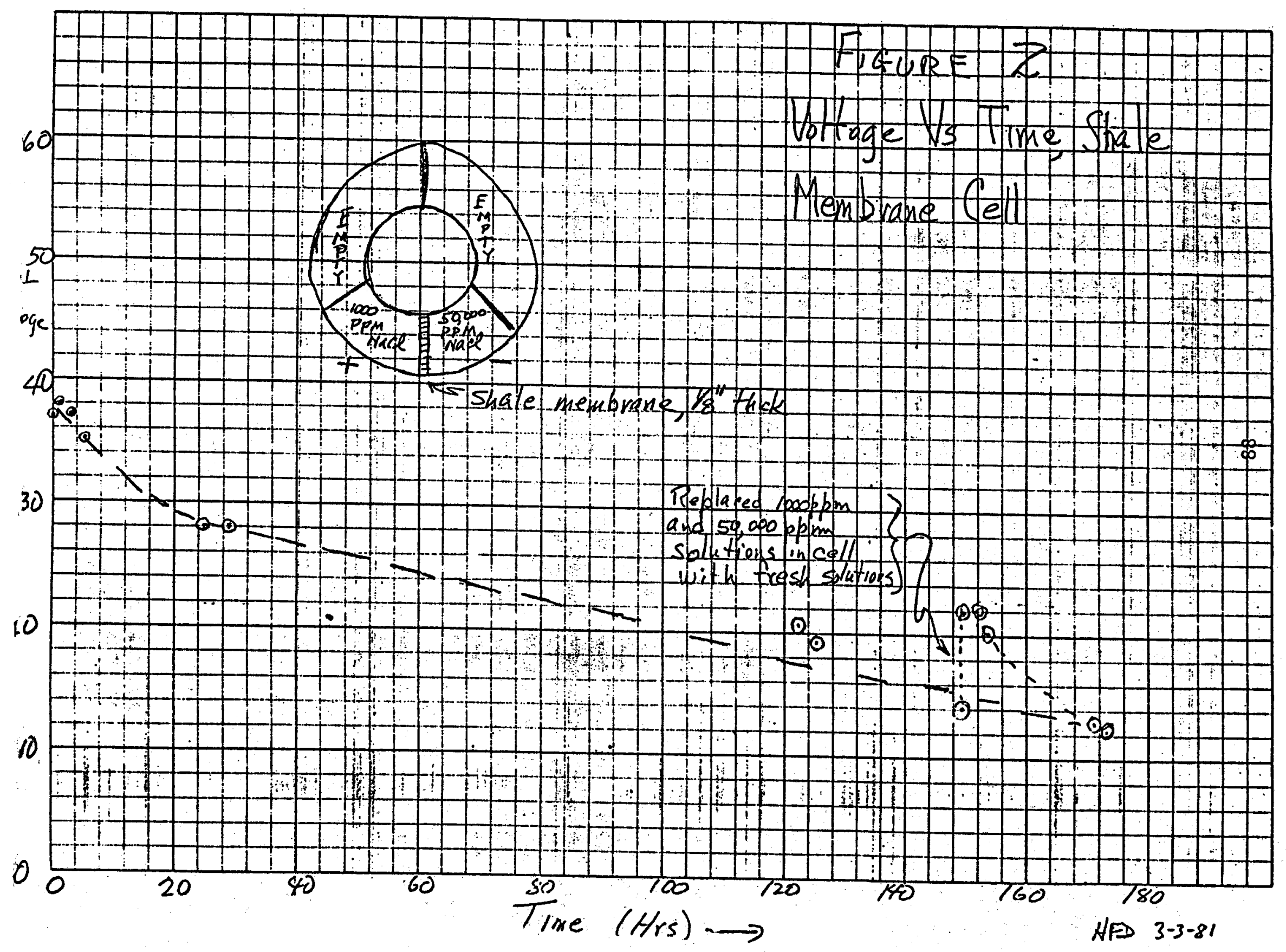

)... 


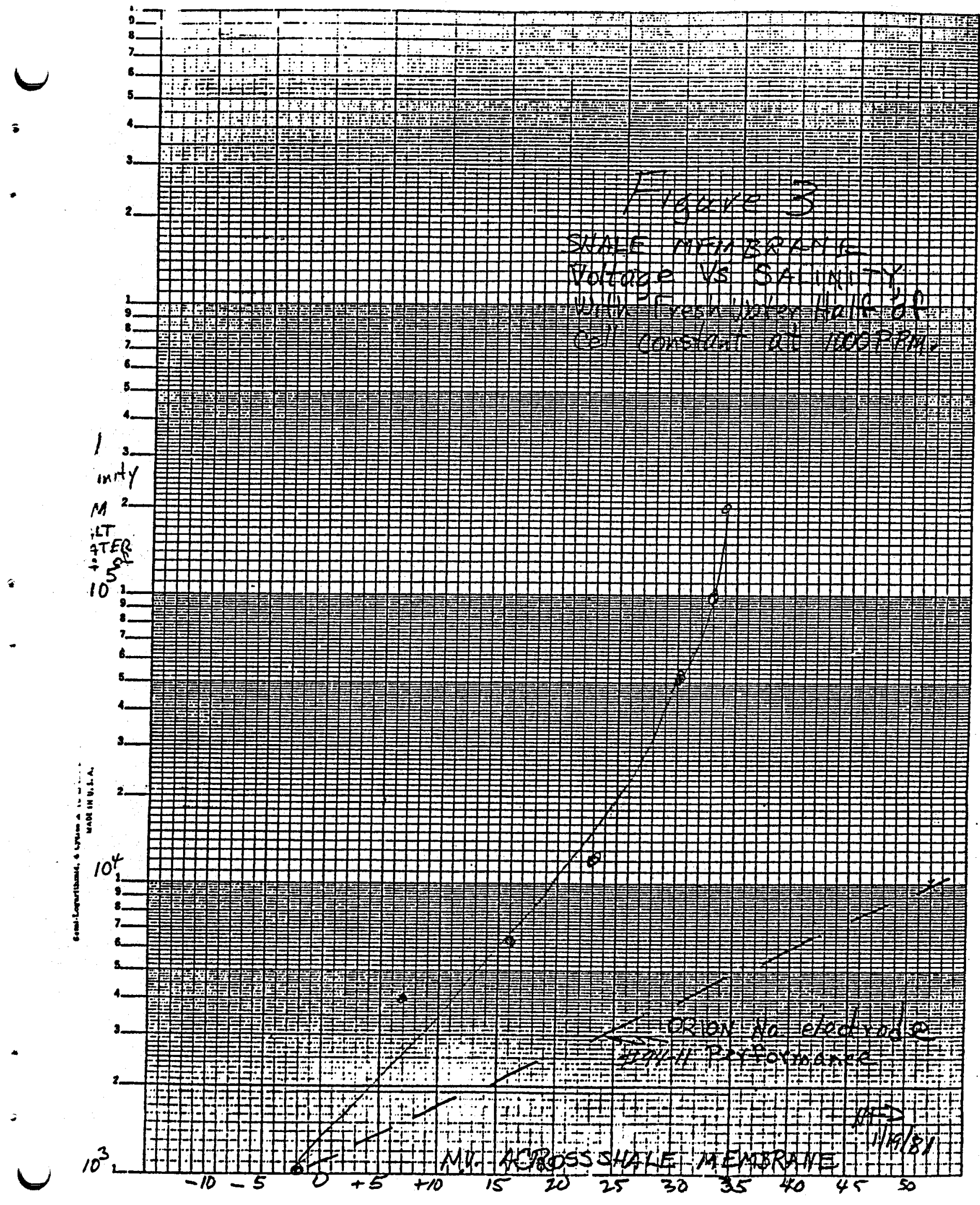




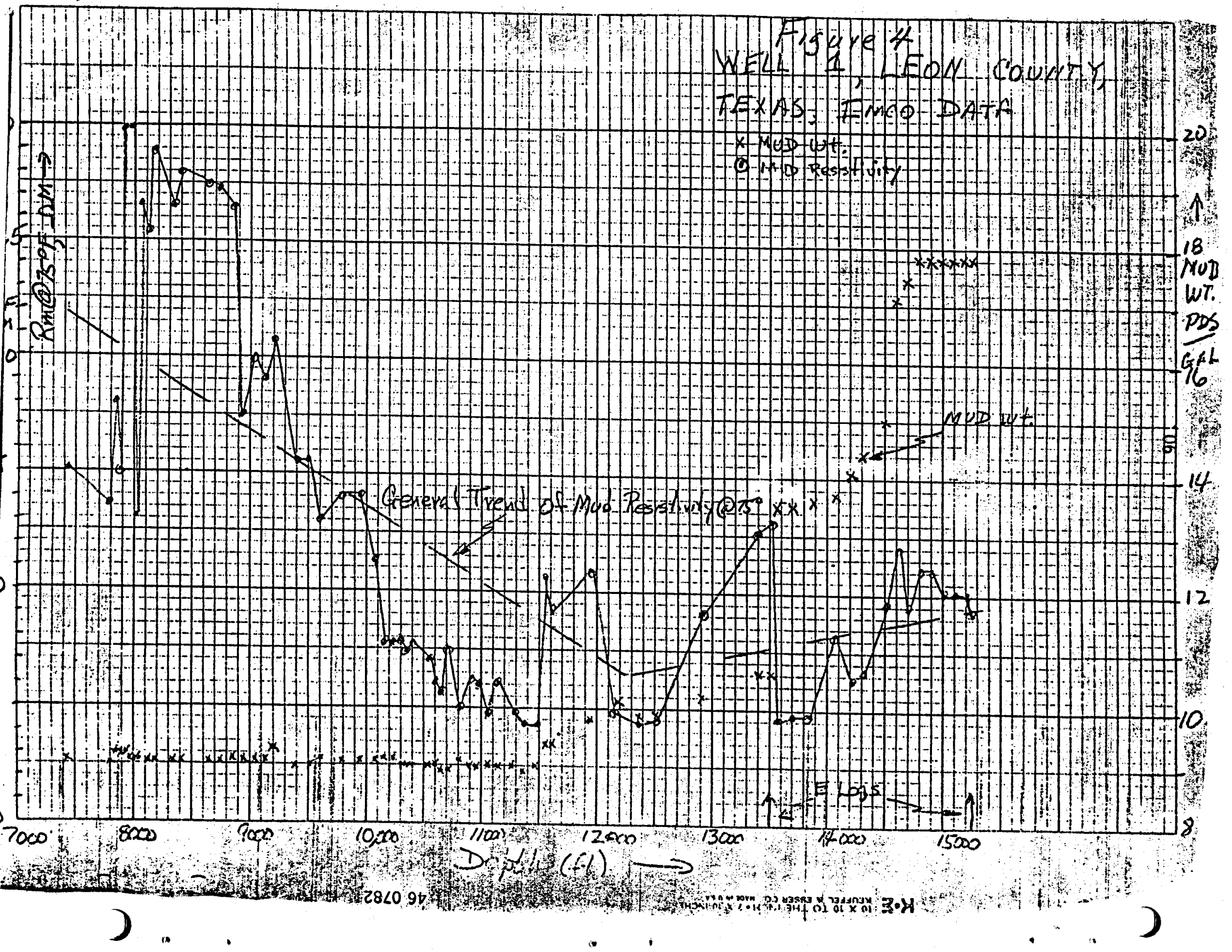




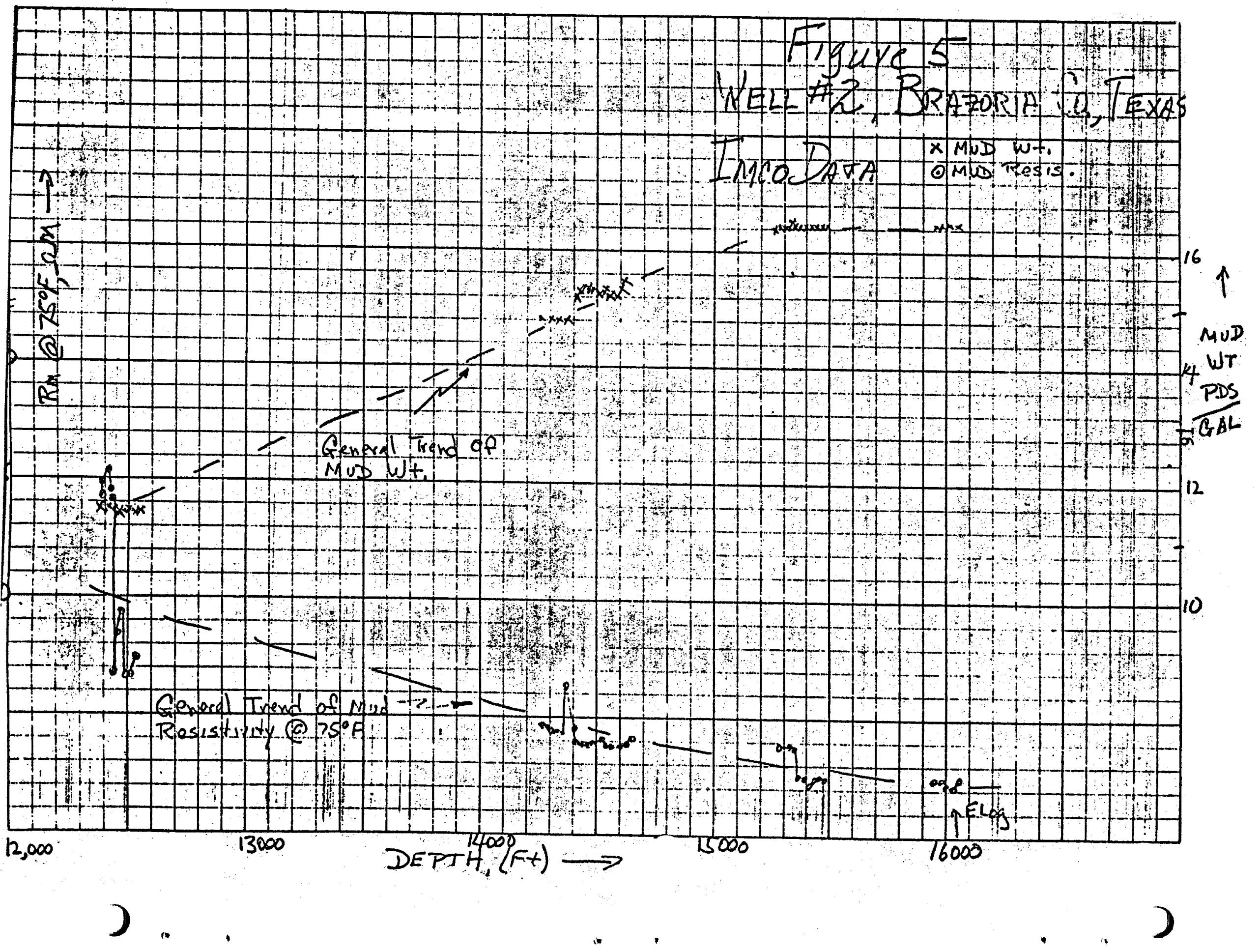




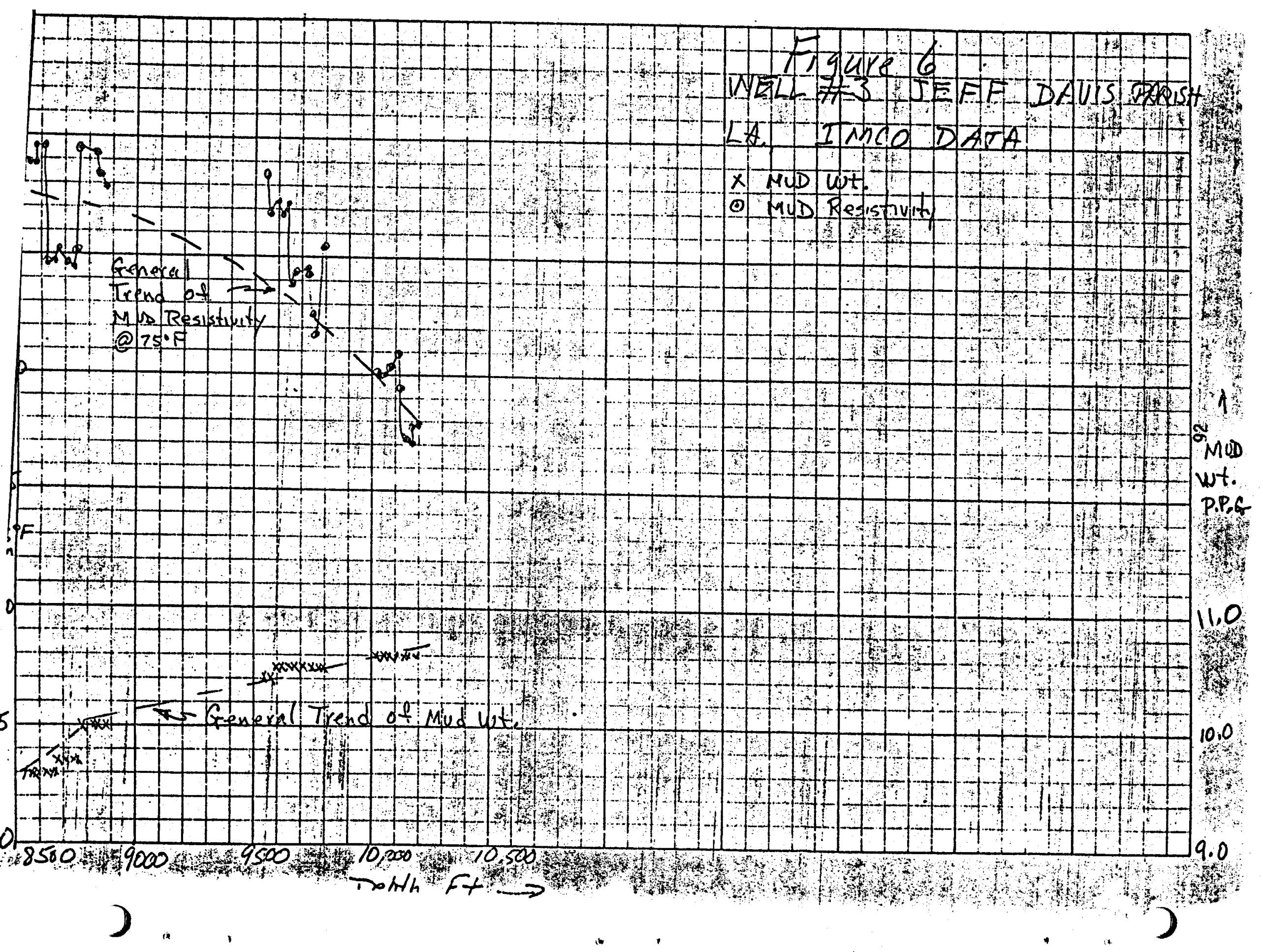




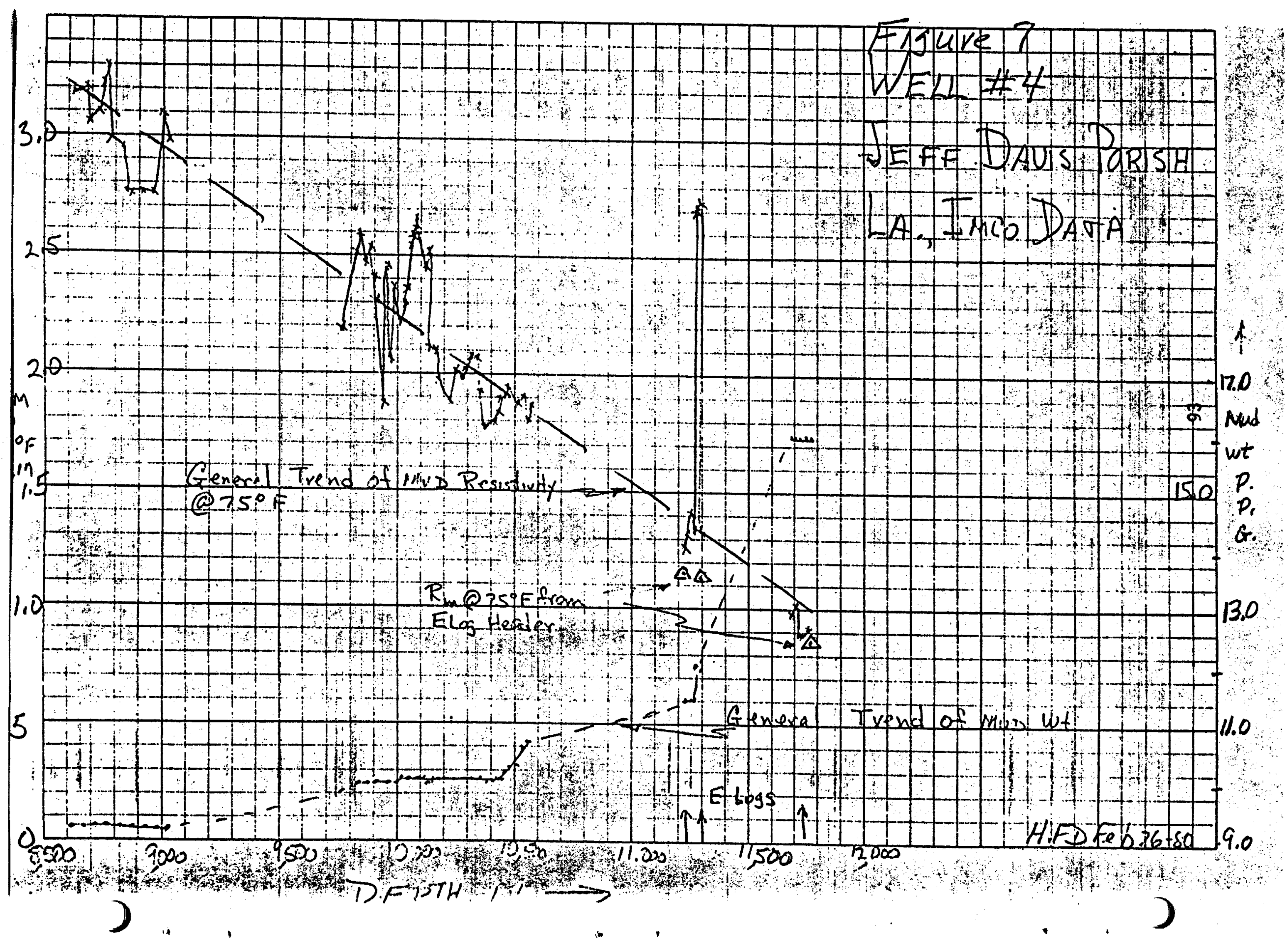




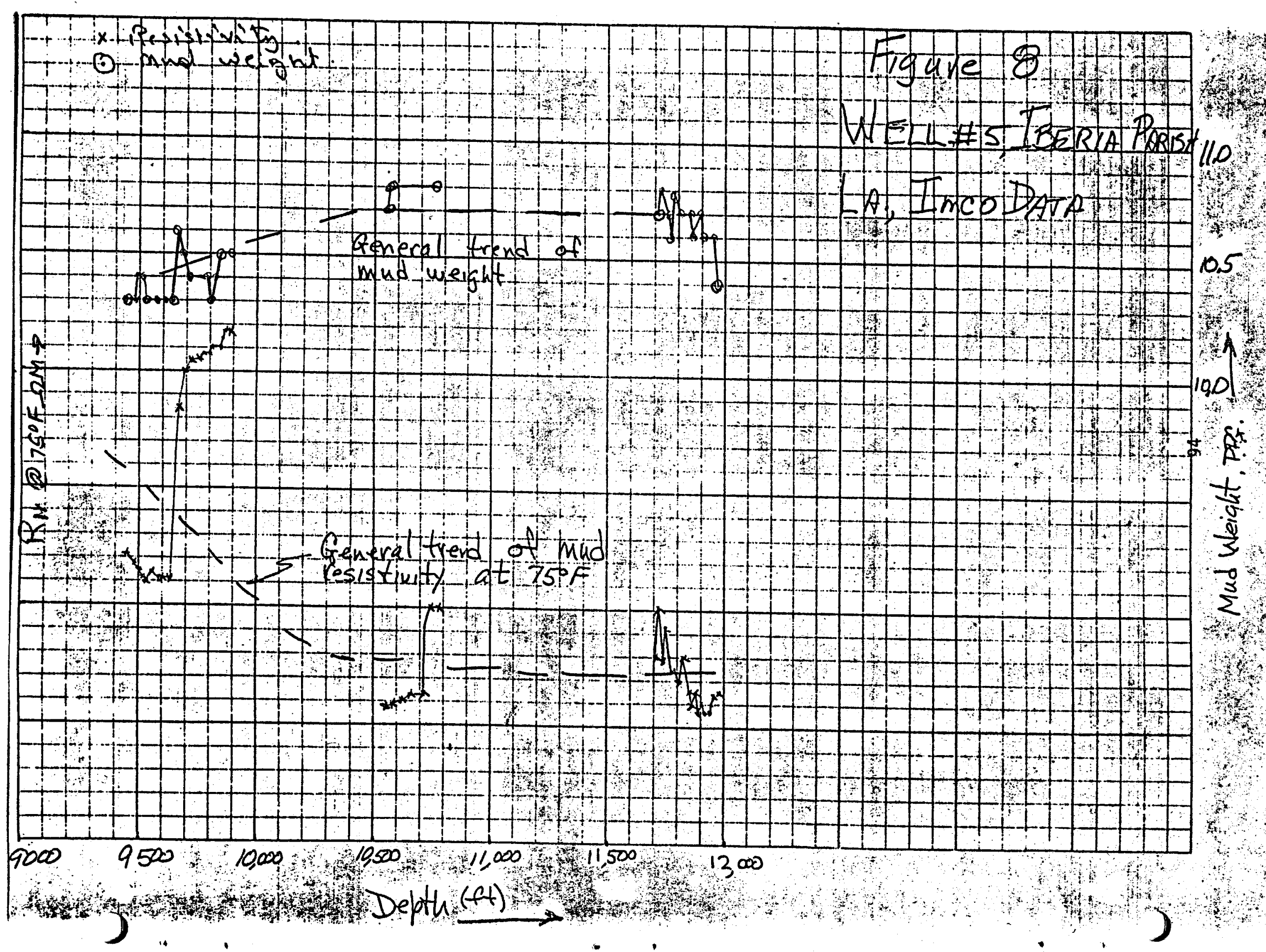




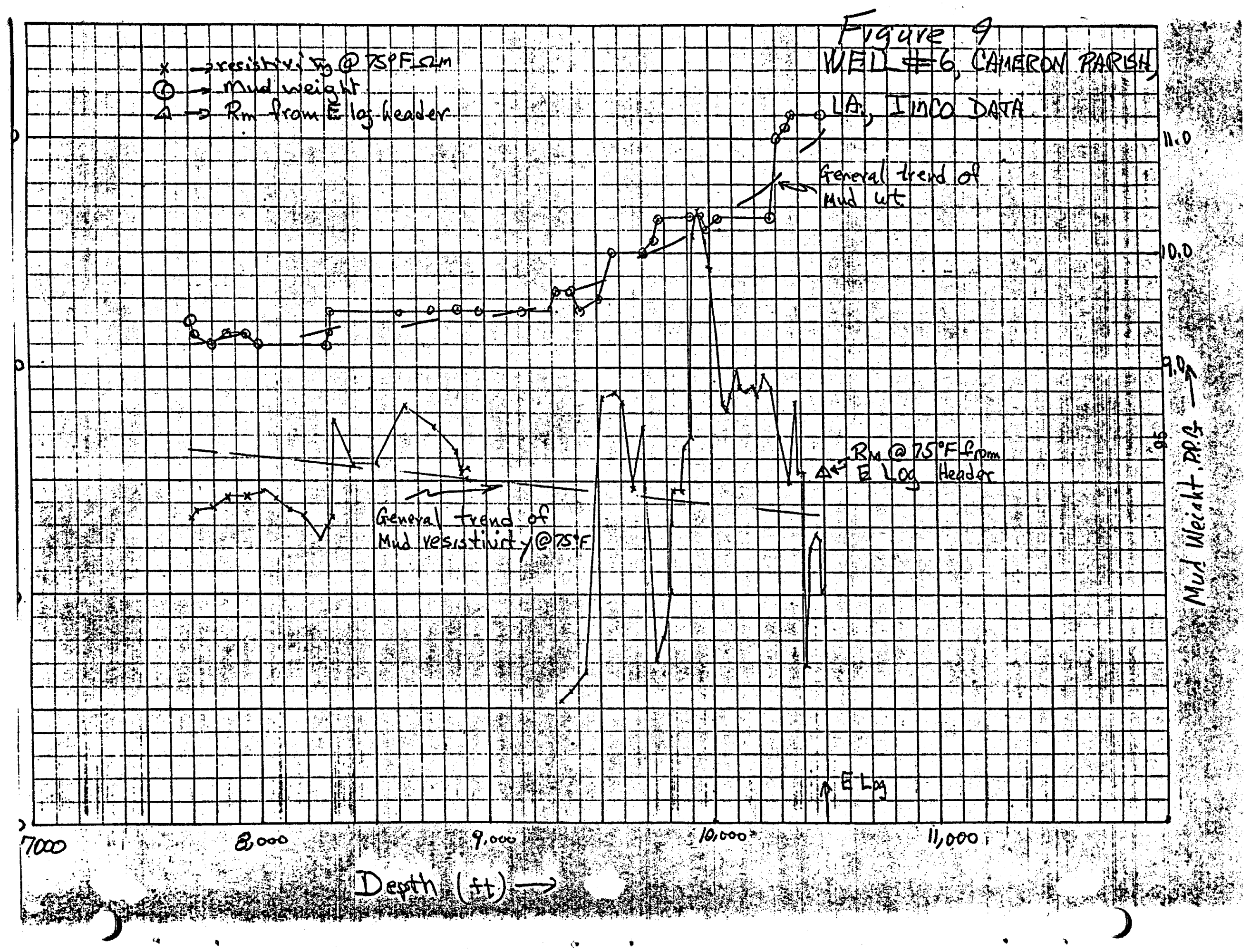




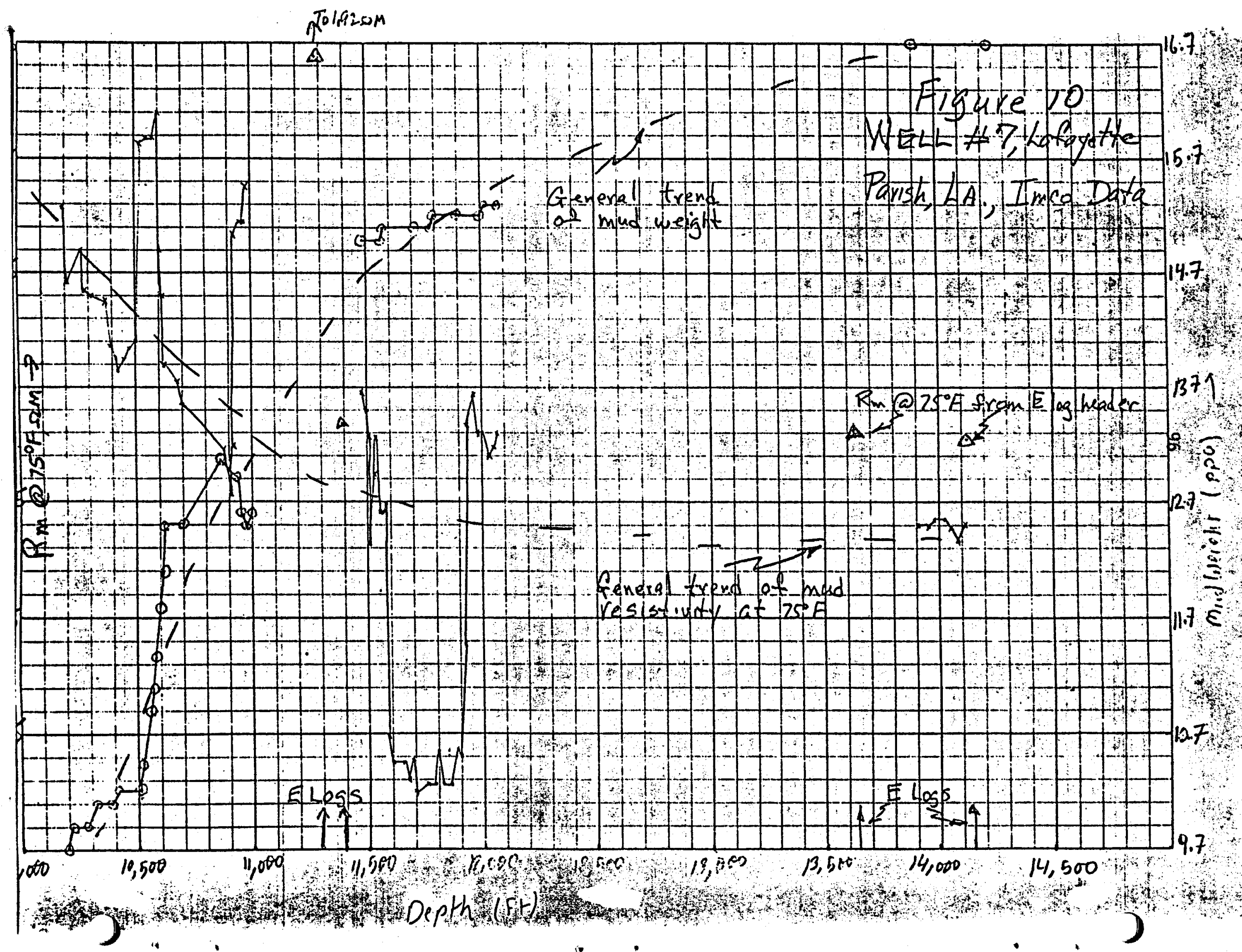




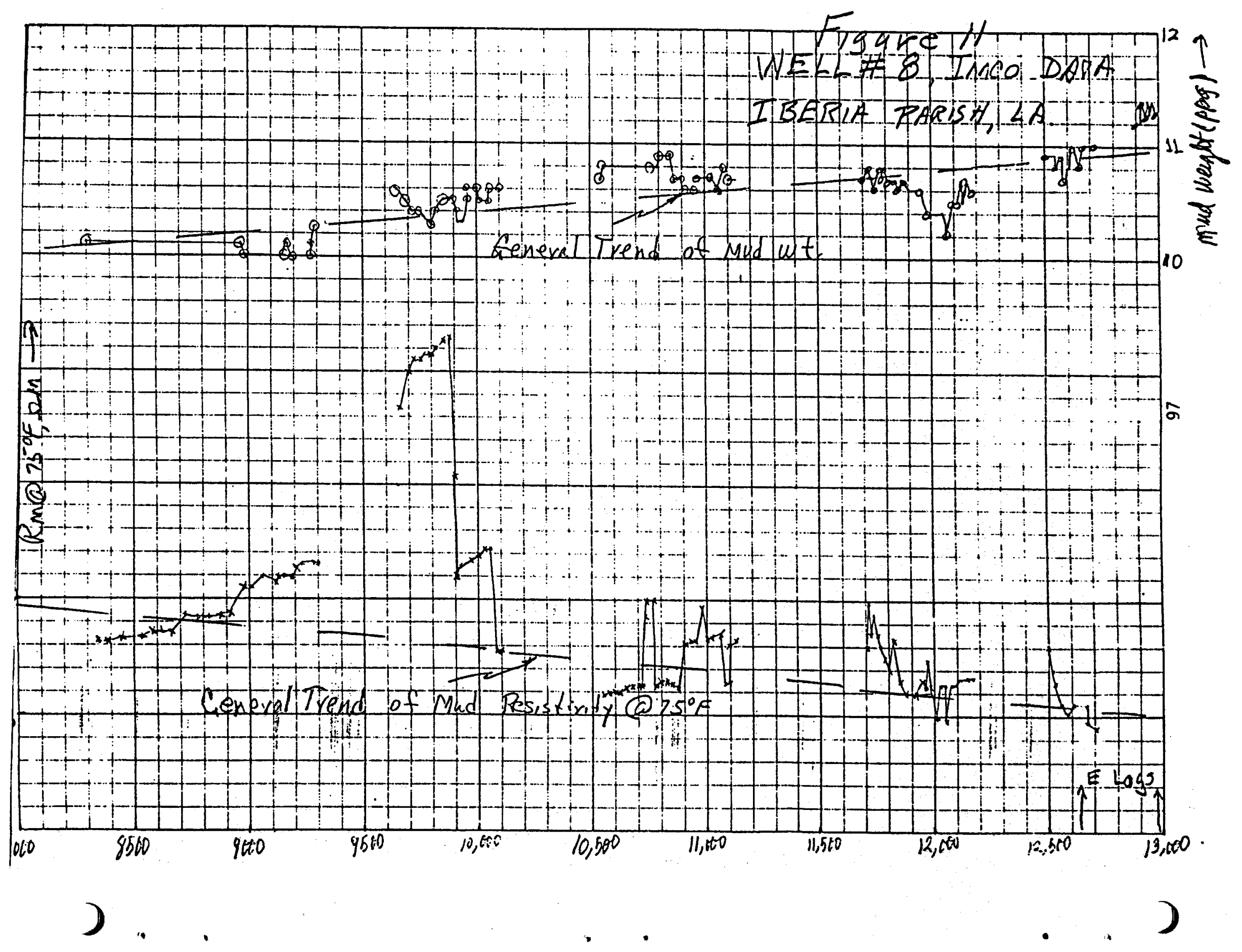




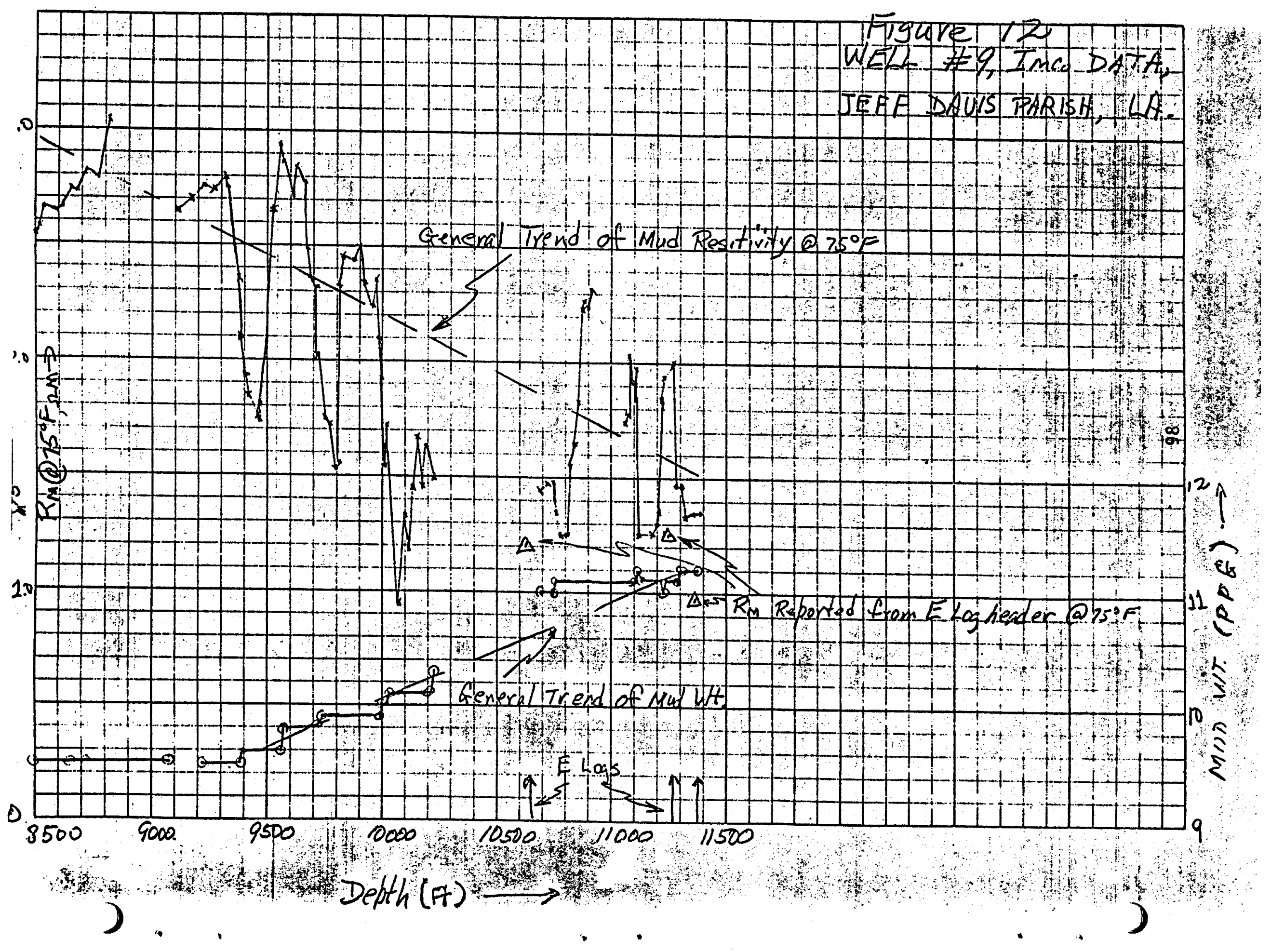




\section{Study of Log Derivęd Water Resistivity Data in Geo Formations}

Summary: We have applled Prof. Basstouni's method of calculating water salInity based on use of shale resistivity to the 16 wells in our data set which were drilled with lignosulfate muds over a broad area of the Texas-Loulalana Gulf Coast. Results were not greatly different from those obtained using the conventional method, with a standard deviation in both cases of about 69,000 ppm. The Basslounl method usually predicts too low a salinity. The difference between these results and the good results reported by Bassiounl earlier presumably arises from the much broader geographic and geologic coverage of our data set. Bassioun1's earlier results were from data taken in a falrly restricted area near Lafayette, La. and were mostly wells drilled with nonlignosulfate muds, while our data set was for lignosulfate muds exclusively.

We haye also calculated the standard deviation between 108 header values of $R$ $75^{\circ} \mathrm{F}$ and the Imco (continuously recorded) values of $R$ for 10 cases in $5^{m}$ wells for which we have these data. The standard deviation was $36 \%$, which is discouragingly high. We have no Imco data for RM, but the assumption is that these varlations would also be large.

We have put considerable effort into preparation of a paper, covering the work of the past year on this project. This paper will be submitted to Geothermal Resources Council for presentation at their 1981 annual meeting at Houston, Texas, Oct. 25-29, 1981; and will also be presented at the Fifth Geopressured Geothermal Energy Conference, Baton Rouge, La., Oct. 13-15, 1981.

Discussion: Table 1 shows data and results obtained from use of Prof. Bassloun1's method when applied to our data set. As can be seen, calculated salininites are usually too low. The standard deviation for this method turns out to be almost exactly the same as for the convential method of calculating water salinity from the SP, 68,500 ppm for Bassiounl's method vs. 69,000 ppm for the standard method. Figure 1 shows a plot of calculated vs. true salinity for our data set when using the Basslouni method.

In telephone conversations with Prof. Bassiouni, I learned that most of his data was for wells not using 1 ignosulfate muds. This, plus the fact that his data comes from a rather 1 imited geologic age range and a limited geographic area near Lafayette, La., may explein the difference in the results for the two data sets.

In our data obtained from Imco on continuous measurement of $R_{4}$ in drilling wells using a resistivity sensor installed in the return mud flow ine, we had opportunity to check $\log$ header values of $R_{M}$ against the Imco values of $R_{M}$ at the same depth. There were 10 such checks possible, distributed through 5 wells. (Some wells had more than one logging run in the Interval for which we had continuous $R_{M}$ data). The data are shown in Table 2. The per cent differences in $R_{M}$ values ranged from near zero to $70 \%$, with a standard deviation of $36 \%$.

Figure 2 shows continuous values of Inco measured mud resistivity and density for a deep well in Brazoria County, Texas, along with $10 g$ header values of $R_{M}$, and depths at whtch $E$ logs were Iun. If we connect the Imco values of $R_{\text {at }}$ the $E$ log depths with a dotted line, as has been done in this figure (the "Meneral trend" IIne) we see a reasonable trend of decressing mud resistivity, 
with no hint of the large and erratic variations in $R_{M}$ occurring between the $E$ log depths. If we calculate the difference between the measured $R_{4}$ values reported by Imco, and the dotted trend line connecting the $R_{\text {values at } E} \log$ depths in this and in the other wells where we have such data, we $f$ ind a standard deviation of $32 \%$ between the continuousiy recorded Imco values and values read from the dotted "general trend" 1 ines.

We are in the process of preparing a paper covering the work on this project during the past year, and will include a draft of the paper as an attachment to our next progress report. We will present the paper at the Fifth Geopressured-Geothermal Energy Conference at Baton Rouge, La., on Oct. 13-15, 1981, and will also submit it for consideration for the Geothermal Resources Counc1l meeting at Houston, Texas, on Oct. 25-29, 1981

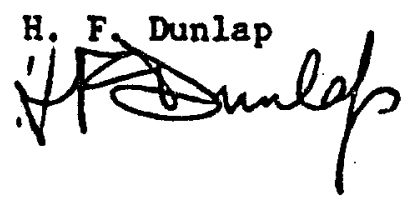




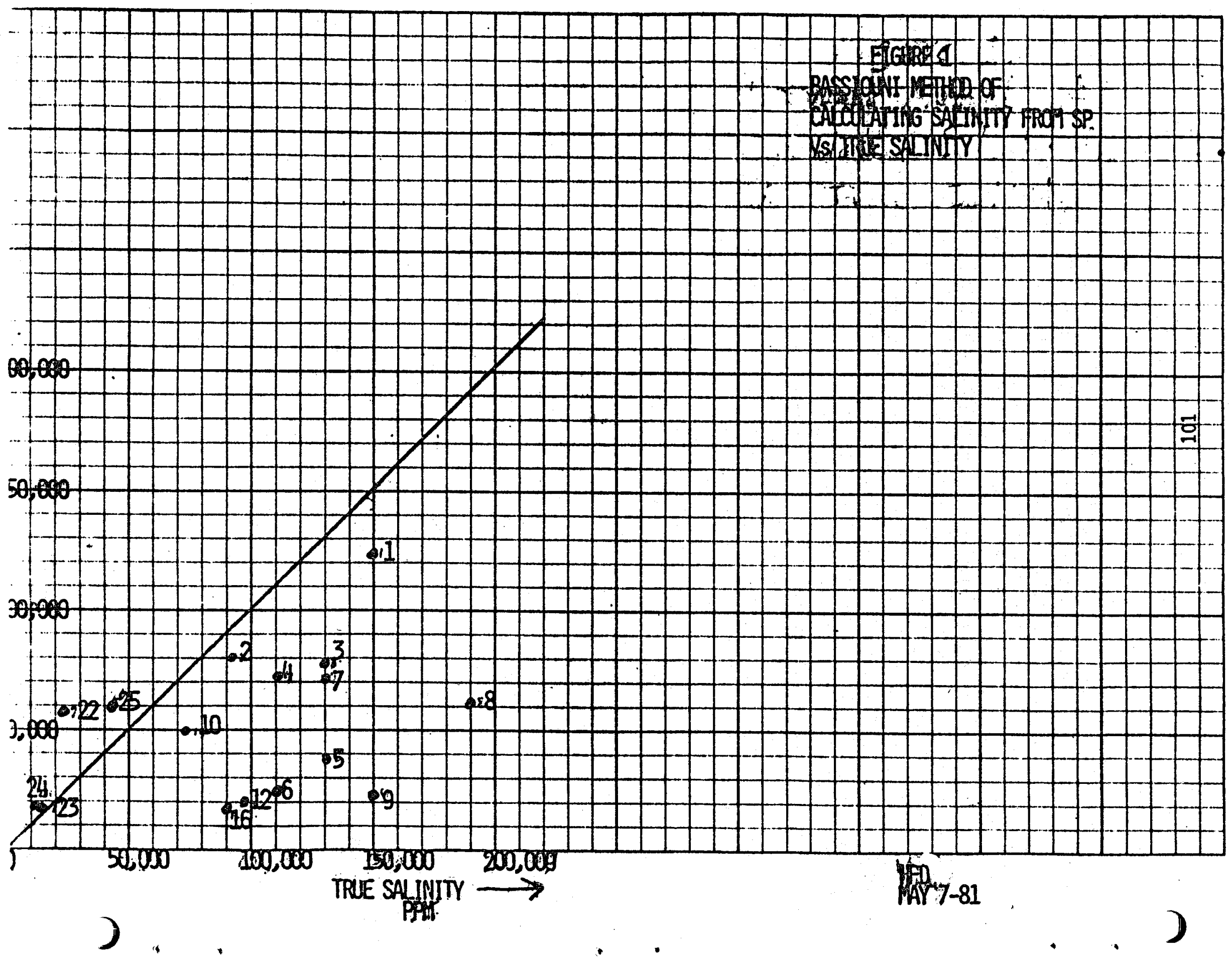




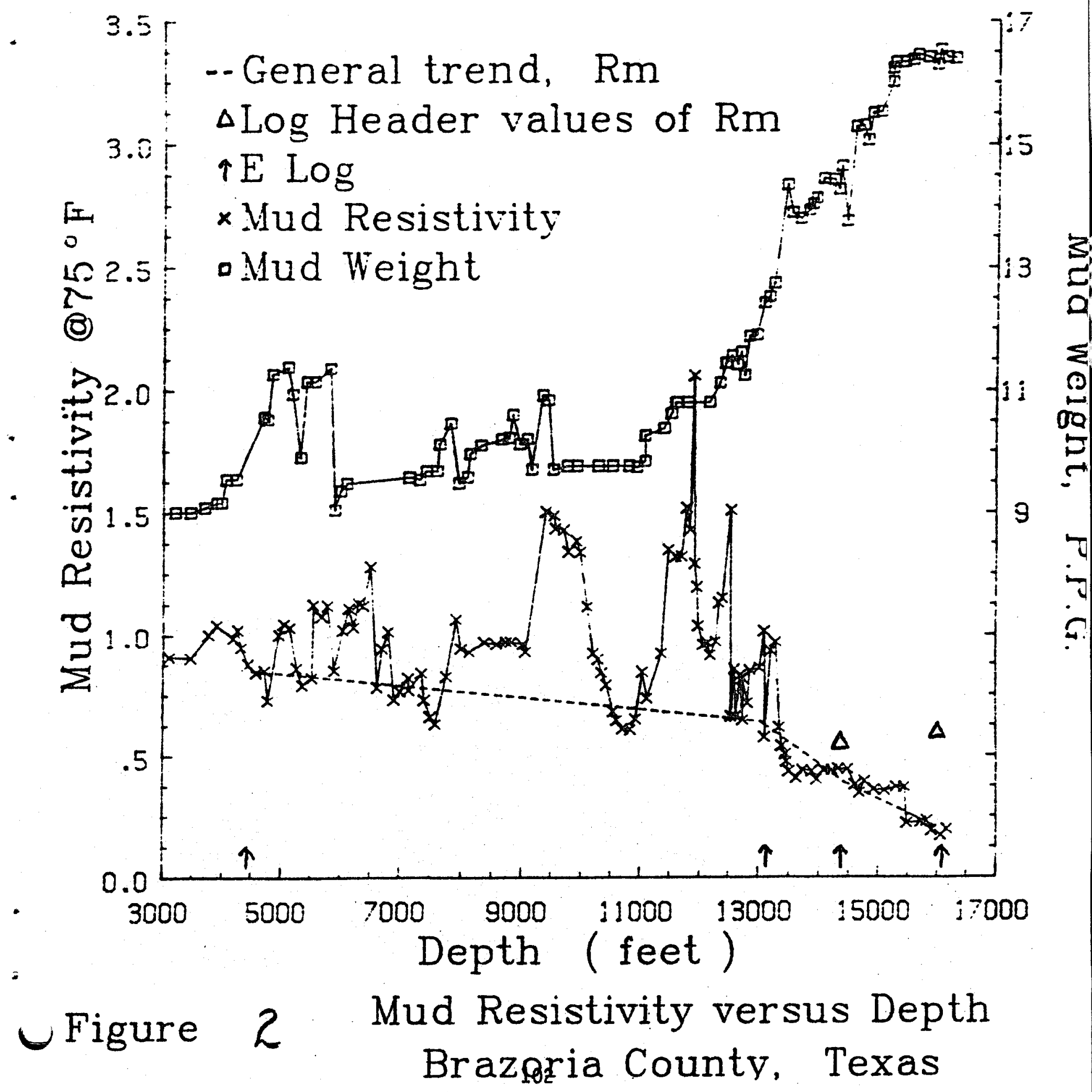


Table 2

Comparison of $\log$ header $R_{M}$ with Imco $R_{M}$ a $75^{\circ} \mathrm{F}$

\begin{tabular}{|c|c|c|c|}
\hline $\begin{array}{c}\text { Imco } \\
\text { Well }\end{array}$ & $\begin{array}{c}A= \\
\text { Log Header } R_{M} \\
\Omega M\end{array}$ & $\begin{array}{r}B= \\
\operatorname{Imco} R_{M} \\
\end{array}$ & $\frac{A-B}{A}$ \\
\hline 2 & .59 & .48 & .19 \\
\hline$"$ & .61 & .20 & .67 \\
\hline 4 & .86 & .90 & -.05 \\
\hline " & 1.12 & 1.32 & -.18 \\
\hline 11 & 1.15 & 1.25 & -.09 \\
\hline 6 & 1.55 & 1.04 & .35 \\
\hline 7 & .89 & .70 & .20 \\
\hline 9 & .96 & 1.35 & -.39 \\
\hline$"$ & 1.25 & 1.95 & -.70 \\
\hline$"$ & 1.20 & 1.45 & -.25 \\
\hline
\end{tabular}




\section{Progress Report \# 15 - May 1981 \\ Study of Log Derived Water Resistivity Date in Geo Formations}

Summary: We have completed preparations of a paper reporting the research on this project during last year. A copy is attached. Wo olan to present these results at the DOE/Industry Geopressured Geothermal Energy Forum at New Orleans, on June 17, as well as at other meet Ings mentioned in last month's report.

We have calculated the standard deviation, $\sigma$, of calculated water salinitles for the 9 cases of non-1ignosulfonate muds in our data set using the Bassioun1 method, the ${ }_{3} \mathrm{Gen} .7$ method, and the " $\mathrm{K}$ " method. These are: BaşsIouni: $\sigma=25,6 \times 10^{3} \mathrm{ppm}$; Gen. $7: \sigma=29.7 \times 10^{3} \mathrm{ppm} ; K_{\mathrm{F}}: \sigma=15.7 \times 10^{3} \mathrm{ppm}$. The geologic age correction useful in the $K_{F}$ calculation for Iignosulfonate muds is not helpful for non-1ignosulfonate muds. Note that all these methods give standard deviations not too different from the value of 21,000 ppm for the lignosulfonate muds after applying the geologic age correction for the 1ignosulfonate mud tests. They are much smaller than the $70,000 \mathrm{ppm}$ standard devlation found for 1 ignosulfonate muds using either the header $R_{\text {mp }}$ values in a conventional calculation, or the Bassiounl method. The implication is that the 1 ignosulfonate muds may be quite different in their SP behavior from the other muds in our data set.

We will attempt to get more non-11gnosulfonate mud tests to add to our data base. We are considering data from several wells in the Red Fish Reef Field, Chambers County, Texas (obtained from files of Bu. Ec. Geol.) which may be suitable for analysis. These are mostly lime base muds.

Discussion: We have prepared a paper (attached) summarizing our research efforts of the past year on this problem, including only data on wells using 1ignosulfonate muds. The final result, which brings the standard deviation in calculated water salinity down from about $70,000 \mathrm{ppm}$ to $21,000 \mathrm{ppm}$ is a significant improvement over the conventional calculation. We believe the remaining error is as high as it is mainly due to large varlations in mud properties between logging runs.

In addition to the Iignosulfonate data, we have 9 tests involving gyp, IIme, driscose, or tannin muds. We have studied these data, to see whether the methods outlined in the attached paper would be applicable. Usibg a " $K$ " curve approprlate to the mud type results in a standard deviation of $15,705 \mathrm{ppm}$. The salinity results do not correlate with geologic age for these muds, so no age correction is possible. Using the Bassioun1 method, the standard deviation is $29,600 \mathrm{ppm}$, and using $R_{M F}$ values from Schlumberger's Gen. 7 curves, the standard deviation is $29,700 \mathrm{ppm}$. None of these deviations are greatly different from the $21,000 \mathrm{ppm}$ found for IIgnosulfonate mud tests using the geologic age correctlon.

Since not many tests were avaliable for a given mud type; the accuracy of the $K_{f}$ determinations for the varlous muds, in particular, are questionable. (We oftained $K_{F}$ for a given non 1 ignosulfonate mud from Fig. 1, Progress Report \#6.) 
The data for these wells are shown in Table 1. Location of the wells, in Texas and Loulsana, is shown in Figure 1. Figure 2 shows calculated vs, true salinity for the Bassloun1, Gen. 7, and " $K_{F}$ " methods.

We belleve we can get considerably more data on weils using non 1 ignosulfonate muds, and will attempt to do this in order to better define the " $K$ " curves for these specific muds. We are presently studying nine cases (môstly lime base muds) from the Red Fish Reef Fleld, Chambers Co., Texas.

H. F. Dunlap June 2, 1981

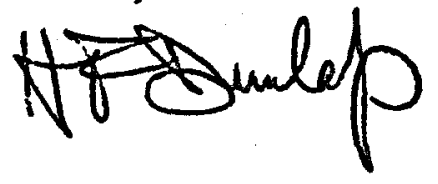


PROBLEMS AND PARTIAL SOLUTIONS IN

USING THE S.P. LOG TO PREDICT WATER SALINITY

IN DEEP HOT WELLS

H. F. Dunlap and M. H. Dorfman

The University of Texas at Austin

\section{Abstract}

Predictions of formation water salinity from S.P. logs using conventional methods are usually too low in deep, hot wells of the Texas-Louistana Gulf Coast. We found a standard devlation of 69,000 ppm when comparing predicted salinities with good measured values. The underest imation of salinity leads to an overestimation of the amount of methane which can be dissolved in these waters, an important parameter in assessing the economic feastbility of geothermal-geopressured projects. We have developed an improved technique using an inferred $R$ value, and a geologic age correction. This reduces the standard deviation to $21,000 \mathrm{ppm}$.

Several factors contribute to the high uncertainties in S.P. derived salinit1es. We belleve the two most important factors are varlations in $\mathrm{Na}^{+}$ion transport efficlency of the shales, plus large, errstic variations in mud resistivity.

\section{Introduction}

The DOE DIvision of Geothermal Energy 1s carrying out a profect to test the feasibility of producing dissolved methane from some of the deep, hot, geopressured aquifers along the Texas-Loulsiana Gulf Coast. Since the anount of methane which cen be d1ssolved in water increases with temperaturf, and presoure, but decreases with water salinity. It is important to select test areas which are thought to contain relattvely fresh waters. The selection has been wade using salinity estimates from the S.P. logs of wells drilled by the 011 and gas industry. Unfortunately, when the flrst well tests were made in areas selected in this way, the produced water turned out to be much saltier than expected. Since this served to reduce olubility of mechane and, hence, methane product Lon ignif 1cantly, the problem la a serlous one.

Therefore, as a portion of our DOE related research, we have attempted to improve the accuracy of salinity estimation from the S.P., and to def ine those var lables which 1 init 1 ts accuracy. Our approach has been to get data on deep hot wells with good S.P. logs, and rellable measurements of produced water resistivity and/or salinity, and see how we could systematically calculate the beat match of the known water salinities in these vells.
Cetting good measured values of formation water resistivity and/or salinity in deep hot wells has been eurprisingly difficult. After considerable effort we have assembled 16 tests which form the data base for the results reported herein. Table 1 shows pertinent data for these 16 tests. These wells were all drilled with 11 gnosulfonate muds, most of them since 1977 , so they represent modern drilling practice. Yud welghts ranged frow 12.2 to $17.9 \mathrm{pP}$, and temperatures ranged from $196^{\circ} \mathrm{F}$ to $332^{\circ} \mathrm{F}$. Geolog $1 \mathrm{c}$ age of format Ions tested ranged from. Upper Mlocene to Eocene Wilcox, as shown in Fig. I. Geographic location of vells tested range from the Rio Grande to the middle Louistana Gulf Coast, as shown in P18. 2.

$$
\text { Table } 1
$$

Test Data Plus Convent Ionaliy Calculated Salinities

\begin{tabular}{|c|c|c|c|c|c|c|}
\hline est & * Ase & $\begin{array}{l}\text { Well } \\
\delta_{F} \text { emp. }\end{array}$ & $\begin{array}{l}\text { SP } \\
\text { SN }\end{array}$ & $\begin{array}{l}\log \\
\text { Value } \\
\operatorname{RigF}_{\operatorname{Mg}}{ }^{\circ} \mathrm{F} \\
\operatorname{SM}\end{array}$ & $\begin{array}{l}\text { Sal1 } \\
1000 \\
\text { Calc. }\end{array}$ & $\begin{array}{l}\text { afty } \\
\text { ppm } \\
\text { True }\end{array}$ \\
\hline $\begin{array}{l}1 \\
2 \\
3 \\
4 \\
5 \\
6 \\
7 \\
8 \\
9 \\
10 \\
11 \\
12 \\
13 \\
14 \\
15 \\
16\end{array}$ & $\begin{array}{l}\text { Anahuac } \\
\text { U. Fr10 } \\
\text { L. Y1ocene } \\
\text { L. K1ocene } \\
\text { I. Fr10 } \\
\text { L. Fr10 } \\
\text { J. K1ocene } \\
\text { Vicksburg } \\
\text { Vicksburg } \\
\text { H. Frio } \\
\text { I. Fr10 } \\
\text { Vicksburg } \\
\text { Anahuac } \\
\text { Jackson } \\
\text { W11cox } \\
\text { Mrio }\end{array}$ & $\begin{array}{l}270 \\
256 \\
196 \\
204 \\
260 \\
288 \\
248 \\
266 \\
266 \\
219 \\
304 \\
332 \\
238 \\
209 \\
250 \\
264\end{array}$ & $\begin{array}{l}80 \\
60 \\
60 \\
60 \\
60 \\
60 \\
60 \\
30 \\
30 \\
60 \\
30 \\
20 \\
35 \\
10 \\
25 \\
40\end{array}$ & $\begin{array}{l}.75 \\
.50 \\
.67 \\
.69 \\
.61 \\
.81 \\
.74 \\
.35 \\
.35 \\
.73 \\
.27 \\
.24 \\
.45 \\
.43 \\
.34 \\
.46\end{array}$ & $\begin{array}{l}68 \\
72 \\
54 \\
51 \\
50 \\
38 \\
48 \\
48 \\
48 \\
49 \\
49 \\
52 \\
42 \\
21 \\
42 \\
43\end{array}$ & $\begin{array}{r}150 \\
92 \\
130 \\
110 \\
130 \\
110 \\
130 \\
190 \\
150 \\
73 \\
98 \\
90 \\
23 \\
15 \\
13 \\
42\end{array}$ \\
\hline
\end{tabular}

The convent lonally calculated alinitles shown In Table 1 were obtalned using the 108 header valves of mud flitrate resistivity, $R$, and well temperatures at test depth, interpolated between data from logging rung above and below the formation tested. The basic equation used is:

$$
\text { (1) Static S.P. } \mathrm{K} \log _{10} \mathrm{Aw} / \mathrm{A} \text { WF }
$$

where Aw and AW are the "activities" respectively of the format 1on water and mud flitrate. Since activities are not comonily measured in the fleld, equation (1) Is universally approximated by

(2) Static S.P. $=K \log _{10} R_{\text {MFE }} / R_{W E}$ 
Dunlap. et al.

where the reciprocal of the equivalent resistivitles of the formation water and wud filtrate replace the ect Ivit les in equat ion (1). For relat ively fresh solutions, the resistivities and equivalent resistivitles are about equal. For very salty solut tons, conversion of $R$ to $R$ is needed which is given in the Schlumberger chărt manual and elsewhere. 2 (For convenlence we will refer to the Schlumberger charts and conversion schemes shown in the 1972 edition). Solution of equation (2) 15 expedited using charts $\mathrm{SP}-1$ and $S P-2$, in the Schlumberger manual. A conversion of water resistivity at a known temperature, to NaCl content in ppm, is given in Schlumberger chart Gen. 9.

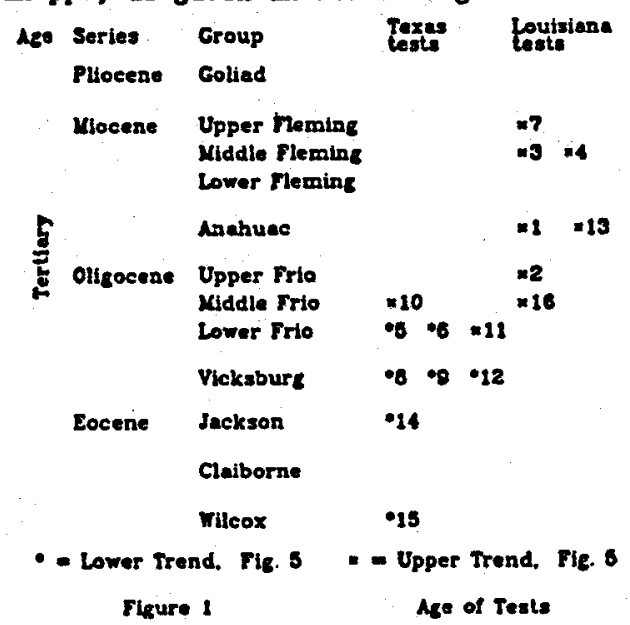

It is apparent from an inspection of the true and conventionally calculated salinitles shown in Table 1 that large errors occur. The calculated salinitles range from 26,000 ppm to $72,000 \mathrm{ppm}$, while the true salinities range from $13,000 \mathrm{ppm}$ to $190,000 \mathrm{ppm}$.

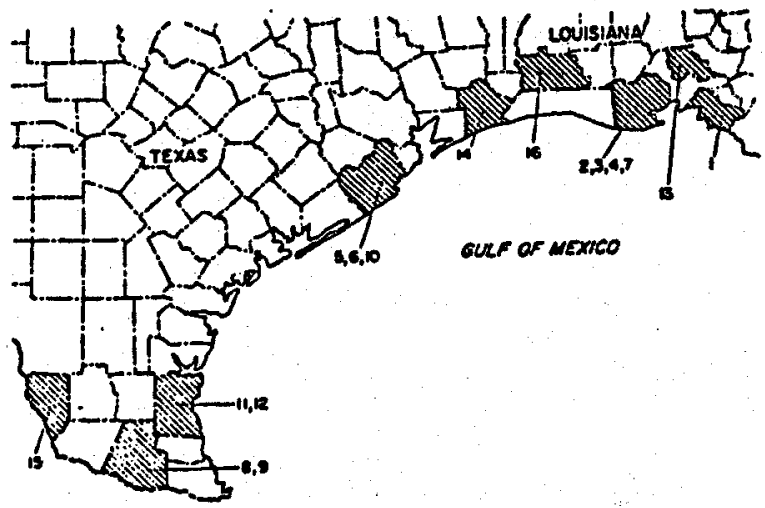

Figure 2. LOCATIOW Of TEST MELLS

\section{Procedures for Reducing Estimation Errors}

If we know the formation water salinity for a produced water sample, we can use equation (2) to calculate the "true" $R, 1$,e. that value which is needed to make equation (2) give the correct format lon water salinity. (It may or may.not be the actual messured $R_{(F}$ ) This was done for each of the 16 tests in our sample group. The results are shown in F18. 3, which shows the rat10 of Log Header $R_{\text {FF }}$ to "true" R kersus mud welght. There 1s a very wide scatter in the data. Most of the data Indicate that the $\log$ header $R_{\text {g }} 18$ greater than the "true" $R$ ". which would imply that the calculated formation water salinity would usually be lower than the true salinity.

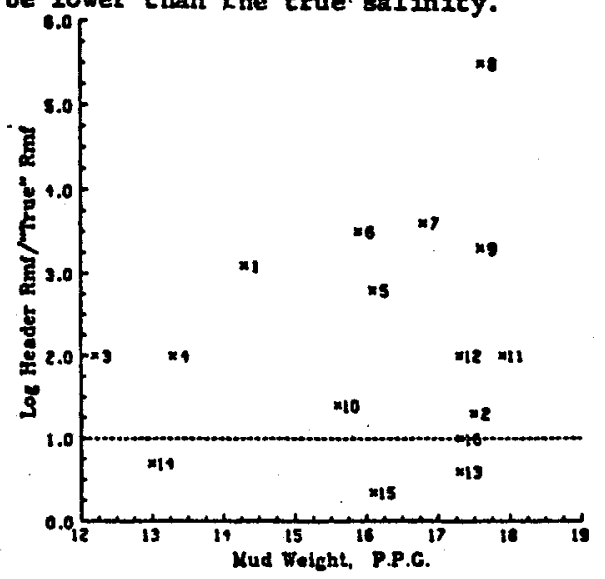

Figure 3 Log Header Rmi/"True" Rmt versus Lud Totght

In 1958, B. L. Overton ${ }^{3}$ studied the relation between mud and mud filtrate resistivities for a number of muds (none of which were 11 grosulfonate, which had not been developed th that time). Be der ived an empirical expression for this relation from his date,

(3) $\frac{R_{M F}}{R_{F}}=C\left(R_{M}\right)^{1.07}$

where "C" 18 a function of mud weight. H1s data are presented in Schlumberger's chart Ger-7. which is prominentiy labelled "Do Not Use For L18nosulfonate Muds." A review of Overton's data chowa considerable scatter when C Is plotted agalnst mud weight, so that a fit with $R$, to the lst power is about as good as equation $(3)$.

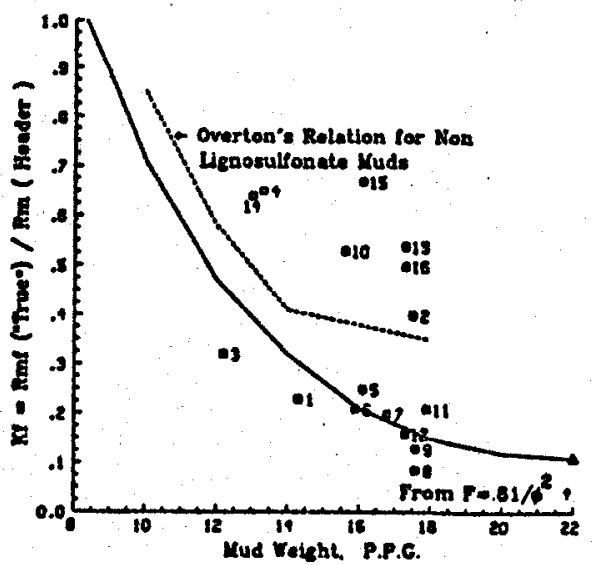

Figure $4 \mathrm{Kl}$ vereve Sud Density

A sintler plot for 11gnomulfonate muds, using our data, is shown in Figure 4 . This shows

$$
K_{F}=\frac{R_{Q F} \text { ("True") }}{R_{M} \text { (Header) }} \text { vo wud we1ght. }
$$


Also shown in Fig. 4 is Overton's relacton (dotted), and a point labelled "From F . $.81 / \phi^{2}$ " at $22 \mathrm{lb} / \mathrm{gal}$ mud density. This mud welght corresponds to $30 \%$ porosity for a slurry with solld component consisting of $40 \%$ barite and $60 \%$ silica. At this porosity an est mate of $R$ can be obtalned from the conventional formation factor relationship $F=.81 / \phi^{2}$, since the "format1on factor" of the mud $181 / K_{\mathrm{F}}$. The points for our data set show a large smount of scatter, but a smooth curve can be drawn along the lower boundary of the data set between $K_{F}=1.0$ e 8.3 P.P.G. and $K_{F}=.11$ @ 22 P.P.G. $K_{F}$ values read from the solid curve hopefully should allow better est1wate of $R_{M F}$ than use of $10 \mathrm{~g}$ header values for AMF $_{\text {' }}$

Some improvement was obtained in this way but errors were st 111 large. A marked additional improvement was achleved when we noted that the calculated salinitles correlated with the geologic age of the formation tested. F1g.5 shows a plot of water salinities calculated using $R$ values obtalned from the $K_{\text {purve of }}$ 18.4, ("Salinity 1"), vs. true water salinities. The data breaks nicely into two trends; an upper trend which turns out to be Lower Frio or younger in age, and a lower trend which includes points from the Lower Frio and older age rocks, (See Fig.1). Three of the formstlons in our data set are in the Lower Frlo, points \#5, \#6, and 11. Here there is a possibility of confusion, but this can sometimes be avolded by noting that all of the Texas tests fall on the lower trend line, and most of the Loulstana tests fall on the upper trend 1ine.

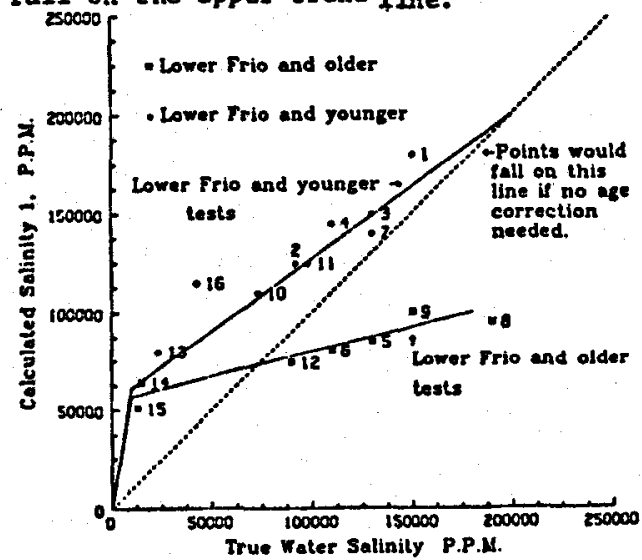

Figure 5 Salinity Correction Based on Geologic Age

If we correct the "Salinity 1" data using the age correction of F1g.5, we obtain "Salinity 2", as shown in Fig. 6.

These data gt 111 show a slope differing slightly from $45^{\circ}$, so a final, empirical correc$t$ Ion based on F1g. 6 was used to obtain "Salinity 3", our best estinate of calculated water salinity for this data set. Fig. 7 shows "Salinity 3" plotted against true salinity, together with the salinIty values obtained if log header $R_{\text {pres }}$ values are used to calculate salinity in the usual way. The "Salinity 3" values are seen to agree with the true values much more closely than do the conventionally calculated values.

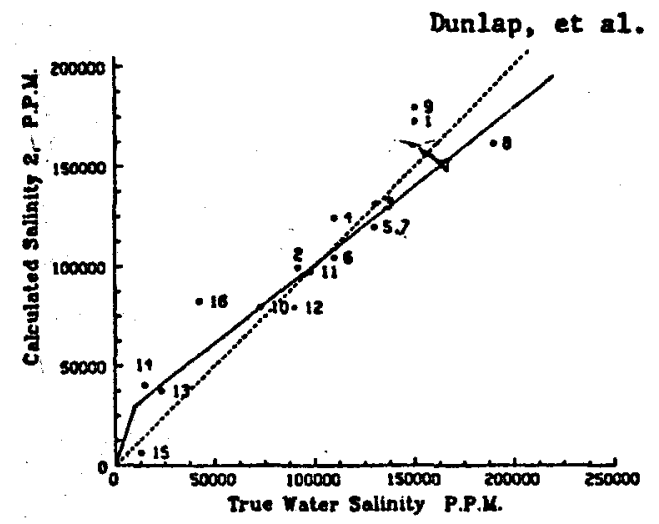

Figure 6 Calculated Selinity 2 (alter age correction) veraus True Salinity

The standard devlation of the "SaIInfty 3" values 18 21,000 ppm, compared to 69,000 ppm for salinity values conventionally celculated.

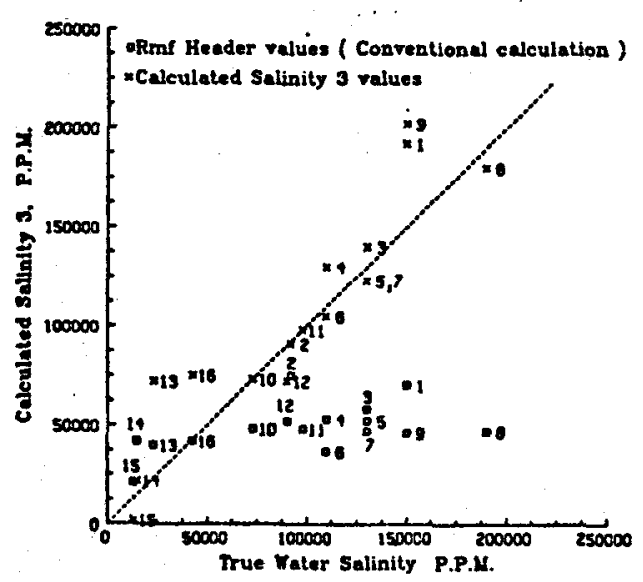

Figure 7 Calculated Salinity 9 versus True Salinity

\section{Reasons for Errors}

A number of factors probably contribute to the h1gh standard deviation for S.P. der ived salinity values. These include: use of NaC1 resistivity ve temperature corrections for the complex solutlons found in muds and mud filtrates; errors in sampling, and field measurement of the resistivity of muds and wud filtrates; use of resistivity data rather than activity data in equat ions (1) and (2); varlation in efficlency of different shale membranes in selectively transporting the $\mathrm{Na}^{+}$Lon; and short term variations in mud and mud filtrate resistivity during driling operations. Of these, we belleve that the last two varlables are most important.

Lab tests show that phale compaction is essent 1al to make a good $\mathrm{Na}^{+}$ton transport membrane. If geopressured shales are less compacted than normal, the membrane efficlency way be decreased, which reduces the calculated water salinity. Also, test made using a freshly cut Cretaceous shale from Montana showed this shale to develop only half the potential calculated using equation (1). If this shale is only $50 \%$ effictent, other shales probably vary in their efficlencles as well. 
Dunlap, et al.

We have had the opportunity to study records of mud resistivity continuously recorded in several Culf Coast wells, (none from our data sample, unfortunately). These show very large short term, as well as long term varlations in mud resistivity 8 the well is drilled. In particular, the data Imply that it is unlikely that the value of $R$ obtained by the logs ing company corresponds very closely with the value of $R$ in the well when a particular formation up hole was drilled. Since much of the filtrate enters the formation during driling (spurt 1088), rather than later, when the well is logged, the value of $R$ in the Invaded zone 18 likely to vary considerably from the R value measured by the logging engineer and recorded on the $10 g$ header.

F18. 8 shows a record of such a well, drilled In Brazor la County in 1979 using a 11gnosulfonate mud. Both $R$ e $75^{\circ} \mathrm{F}$ and mud weight vs depth are shown, together with $10 g$ depths. For the two deepest $\log$ runs, the $\log$ header values of $R_{y} \odot 75^{\circ} \mathrm{F}$ are also shown. Note the large (100\%) and erratic short term variations in $R$. These correlate poorly with mud weight varfations. Note also the long term trend for $R_{\text {e }}$ c $75^{\circ} \mathrm{F}$ to decrease as depth increases. Note finally the large differences between the 108 header values of $R$, and the

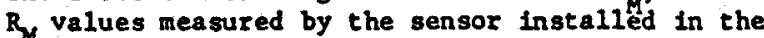
mud flow 11ne. These phenomena are typical of data observed in some IO recent Gulf Coast wells studied.

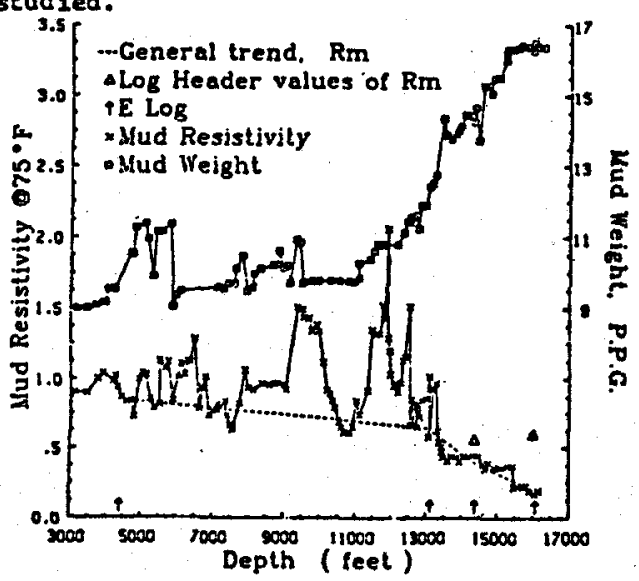

Figure 6 Mud Resistivity versus Depth

We calculated the standard deviation of the continuously measured $R$ values between logsing runs for 10 intervals in 5 different wells, relative to the general trend of $R$ values between $10 \mathrm{~g}-$ ging runs. The atandard deviations ranged from close to zero, to $1 \Omega M$ e $75^{\circ} \mathrm{F}$. With these large and erracic varlations in $R_{M}$, it is no wonder that SP derfved formation water salinities are also not very rellable.

\section{Appl lcation to 011 and Gas Exploration}

Obtaining a correct value for formation water resistivity is also important in $10 g$ analysis for oll and gas production. According to the Archle equation, the formation resistivity $R$ is a function of water resistivity $R$, porosity $\phi$, and water saturation $S_{w}$, is shown in aquetion (4).

$$
\text { (4) } R_{T}=\frac{-81 R_{W}}{\phi^{2} s_{W}^{2}}
$$

Since formations with $S$ values greater than 50 to $60 \%$ are 11 kely to prodứce large amounts of water, a deciston to test zone in an exploratory well is often made on the basis of $S$ values calculated using eq. 4. If $R$ is too high by factor of 2 (water too fresh by 2 factor of 2 ) the $S$ value will be too high by factor of $\sqrt{2}=1.4$. For example, a formation with true $S$ of $45 \%$, which might make oll or gas with very little water, would calculate an $S$ of $.45(1.4)=637$. This might discourage a têst of the zone and lead to loss of valuble ofl and gas reserves.

\section{Acknowledgements}

Th1s work was carried out for the D.O.E. Division of Geothermal Energy, and was supported by them and by a grant from Chevron $011 \mathrm{Co}$. We are grateful to Inco Services Div. for release of data on variation of $R$ in drilling vells. Mr. Chet Garrett of the Texas Bureau of Economic Geology was helpful in dating some of the zones tested.

\section{References}

1. Frick, T. C., 1962, Petroleum Production handbook, Vo1.II, McGraw H111, p.22-13.

2. Schlumberger, 1972, Log Interpretatton Charts, p.11.

3. Overton, H. L., 1958, "A Correlation of Electrical Properties of Drilling Fluids with Sol$1 d 8$ Content," S.P.E. Trans., Vo1. 213, pp.333336.

4. Schlumberger, 1972, Log Interpretat1on Charts, p.7.

5. J. G. HcKelvey \& I. H. Kilne, 1960 , "rlow of Salt Solutions through Compacted Clay," Proc. 9th Nat. Conf. on Clays \& Clay Minerals, pp. 248-259. 
Table 1

Non Llgnosulfonate Mud Test Results

\begin{tabular}{|c|c|c|c|c|c|c|c|c|c|c|}
\hline & & & & Test & Mud & Test & \multicolumn{4}{|c|}{ Salentty ppe $\times 1000$} \\
\hline Test \# & Well Name & Mud Type & Geol. Age & Depth & Wt. ppg & Temp ${ }^{\circ} F$ & True & Bassiouni & Gen. 7 & $\mathbf{K}_{\mathrm{F}}$ \\
\hline 11 & $\begin{array}{l}\text { Humble } \\
\text { La. Terre D-7 } \\
\text { Terrebonne Par, La }\end{array}$ & Gyp & Miocene & $\begin{array}{r}15225- \\
380 \\
\end{array}$ & 17.1 & 235 & 68 & 65 & 70 & 70 \\
\hline 13. & $\begin{array}{l}\text { Sun Jeffries } 2 \\
\text { H1dalgo Co., Tex. }\end{array}$ & $"$ & V1cksburg & $9913-20$ & 15.9 & 244 & 52 & 14.5 & 60 & 59 \\
\hline 14 & $\begin{array}{l}\text { Sun State Laguna } \\
\text { Madre } 11 \\
\text { Kenedy Co., Tex. }\end{array}$ & Lime & Mid Frio & $10348-53$ & 13.0 & 244 & 82 & 47 & 96 & 91 \\
\hline 15 & $\begin{array}{l}\text { Texas Weiting } 1 \\
\text { Brazoria Co, Tex. }\end{array}$ & $"$ & Lower Fr 10 & $12101-29$ & 17.1 & 227 & 90 & 60 & 60 & 130 \\
\hline 17 & $\begin{array}{l:l}\text { Sun State } 76 & 8 \\
\text { Aransas Co. } & \text { Tex. }\end{array}$ & $"$ & $"$ & $9644-64$ & 16.1 & 193 & 80 & 52 & 37 & 75 \\
\hline 18 & $\begin{array}{l}\text { Ph1ll1 1ps Houston } \mathrm{M}-2 \\
\text { Brazor 1a } \mathrm{CO} \text {, Tex. }\end{array}$ & Driscose & $"$ & $11470-80$ & 13.5 & 191 & 48 & 47 & 78 & 46 \\
\hline 19 & $\begin{array}{l}\text { Phillips Houston 2-1 } \\
\text { Brazor 1a Co. Tex. }\end{array}$ & $"$ & $"$ & $12620-28$ & 17.2 & 235 & 68 & 78 & 100 & 55 \\
\hline 20 & " & 1 & $"$ & $12829-38$ & 17.1 & 240 & 55 & 76 & 98 & 57 \\
\hline 21 & $\begin{array}{l}\text { Phillips } \\
\text { Kentzelman } 1 \\
\text { Brazorla Co. Tex. }\end{array}$ & Tann in & Mid Fr10 & $\begin{array}{l}10960- \\
11032 \\
\end{array}$ & 14.9 & 193 & 56 & 37 & 40 & 67 \\
\hline
\end{tabular}




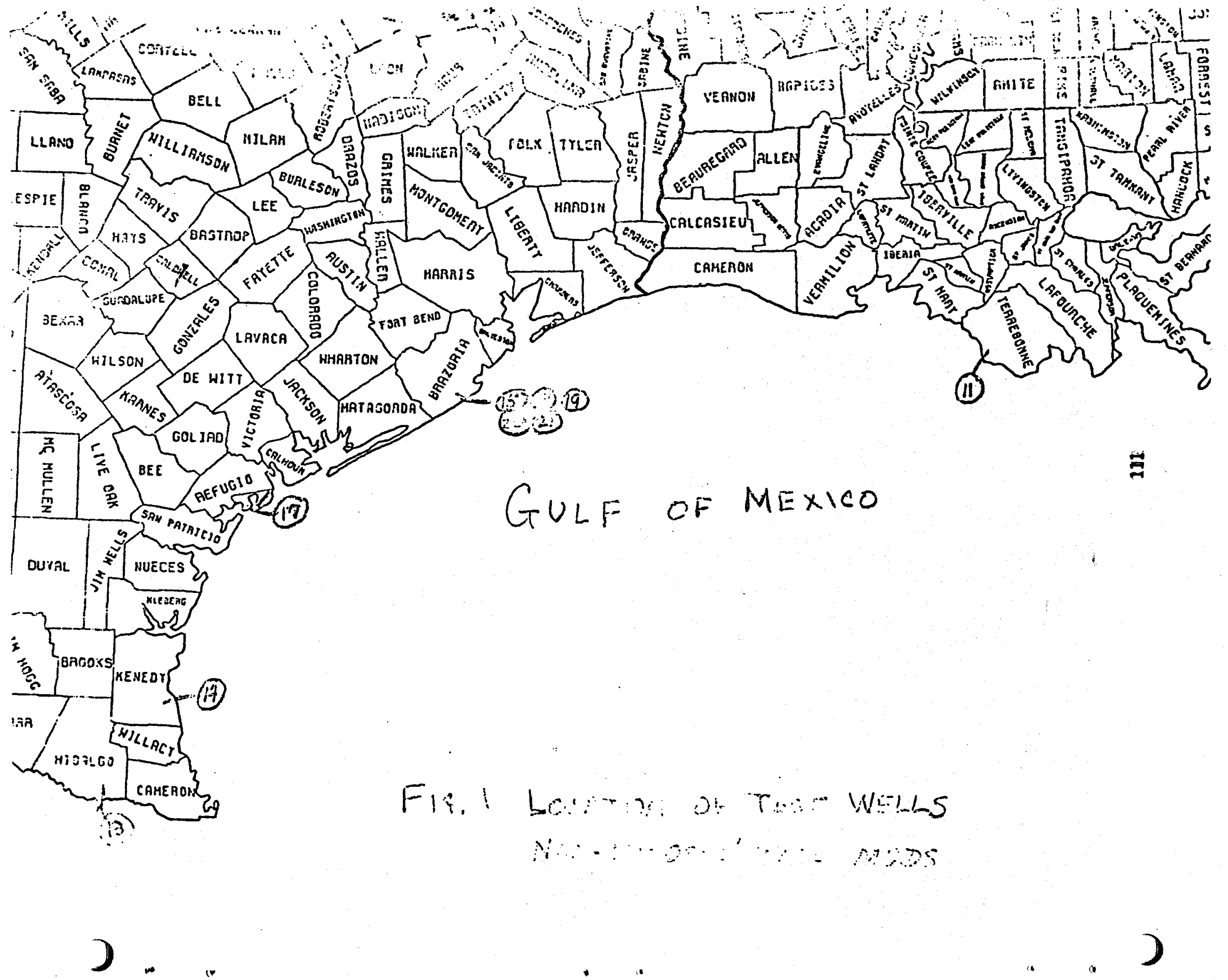


Geothermal Board of Advisors

Page 22...

Progress Report \# 16 June 1981

Study of Log Derived Water Resistivity Data

in $\mathrm{Geo}^{2}$ Formations

Summary: We have worked with Messers Eddle Parker and F. M. Rago in devising a computer program for drawing the shale baseline for SP logs. Previous programs used have not been satisfactory. Considerable improvement has been achleved, and in a test on three wells the standard deviation of the computer calculated SP (relative to values I would have read from $10 \mathrm{~g}$ ) ranged from $3.2 \mathrm{M} . \mathrm{V}$. to $6.6 \mathrm{M} . \mathrm{V}$., with an average of $5.3 \mathrm{M} . \mathrm{V}$. For a typical hot deep well, an error analysis shows that this corresponds to a standard deviation of $12 \%$ in calculated $R_{w}$, which is not large compared to other errors in the system.

We attended the recent meeting of the DOE-Industry Geopressure Geothermal Forum at New Orleans, and presented our paper on "Problems and Partial Solutions etc", attached to last month's Progress Report. We also attended the SPWLA 22nd Annual Logging Symposium at Mexico City, where Basslouni and Silva'a paper "New Approach to Determination of Formation Water Resistivity from SP Log"; and Moore and Kaufman's (Chevron) paper "Your Unsuspected Problems: Resistiv1ty and Water Analysis" were evidence of Interest in this area. Our own paper was submitted too late for consideration at this meeting.

We have obtained coples of $10 \mathrm{gs}$ and data sheets used in Bassioun1 and S11va's paper courtesy of Prof. Bassioun1. Most of Bassloun1's water data comes from two papers by $K$. K. Kharaka et $a 1^{1,2}$. We are having some difficulty in understanding some of this data since there seem to be depth discrepancies in some of the data, and inclusion of water samples of doubtful validity (too much gas production with the water). We also have trouble understanding the shale resistivity values used by Bassiouni in some of these calculations. We plan to make a detalled calculation using Basslouni's method with this data set. (See Basslouni's paper, attached.) Hopefully we can resolve questions by discussion at some convenient time in the future.

Discussion:

Use of the digitized logs in the log data base "Logdex" has been held up In part due to lack of effective software, which would calculate $R_{w}$ from the SP 10g, for example. One of the problems has been to draw a good shale base line 
and to read the SP on the sands encountered in the well, using only the digitized $10 g$ and the computer program. Prevlous attempts to do this have not been too satIsfactory, due to fallure of programs to recognize base line shifts, etc. We have worked with Messers Eddie Parker and Francis Rago durling the past month to try to Improve this capability, with some success. Mr. Rago has devised a program that shows a lot of promise. In a test carried out on three wells, the standard deviation of the computer derived SP relative to the SP which I measured on a total of 50 sands in these wells averaged $5.3 \mathrm{MV}$. (See Table 1.) An error analysis shows that a $5.3 \mathrm{MV}$. uncertainty in SP translates to a $12 \%$ erxor in $R_{w}$ for a typical deep hot well, all other varlables being known perfectly. (See attachment 1.)

At the DOE-Industry Geopressure Geothermal Forum meeting at New Orleans. Prof. Bassioun 1 very kindly provided us with coples of the logs and data sheets for the data presented in his and Silva's paper. (See attachment II.) We have begun to review this data, preparing to carry out their calculation method using their data set, but have encountered problems. We are not sure about the validity of several of the water samples used (most1y taken from Kharaka's papers ${ }^{1, ?}$ ) in view of depth discrepancles between 11sted depths of samples and depths where sands occur on some of the logs; because some of the samples were taken from wells with rather high gas fwater ratios, leading to possible dilution of format lon water with water condensed from gas; and also because of uncertainty in fust how the shale resistivity values were selected. Often the shale resistivity is different above and below the sand belng analyzed, and in these cases we have been told that the mean resistivity should be used. Also we understand that the shale resistivity should be taken quite close to the sand ( $10^{\prime}$ or less away), since the shale properties controlling the Nat Ion transport (and hence, the SP generated) must be close to the sand to affect the system. Some of the shale resistivities listed on Bassiouni's data sheet do not occur within $50^{\prime}$ to $100^{\prime}$ of the sand being analyzed. We hope to clear up these questions with further discussions between BassLoun1, Kharaka, and myself.

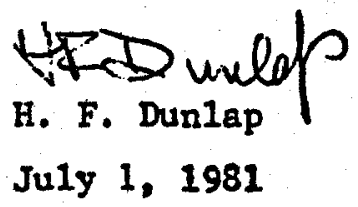




\section{References:}

1. Geochemistry of Geopressured Geothermal Waters from Texas Gulf Coast, Kharaka, Callender, and Carothers, Proc. 3rd Geopressured-Geothermal Energy Conf., Vo1. 1, Pp. GI-121-165, 1977.

2. Chemistry of Waters in Geopressured Zone from Coastal Loulstana-ImI1cations for Geothermal Development, Kharaka, Brown, and Carothers, Geotherma1 Resources Council, Transactions, Vo1. 2, pp. 371-374, Ju1y, 1978. 
Table 1

Test of Computer Derived S.P. Values

\begin{tabular}{|c|c|c|c|c|c|c|}
\hline $\begin{array}{l}\text { Well Name \& } \\
\text { Location }\end{array}$ & Logdex & $\begin{array}{l}\text { Depth Interval } \\
\text { processed (ft) }\end{array}$ & $\begin{array}{l}\text { No. of Sands } \\
\text { analyzed }\end{array}$ & $\begin{array}{l}\text { Max. Diff. } \\
\text { in'S.P. (MV) }\end{array}$ & $\begin{array}{l}\text { B las } \\
\text { (MV) }\end{array}$ & $\begin{array}{l}\text { Std. Devi: } \\
\text { (MV) }\end{array}$ \\
\hline $\begin{aligned} & \text { S.W. Gas, McDonald \#1 } \\
= & \text { Brazoria Co, Texas }\end{aligned}$ & 141 & $2486-9280$ & 13 & 18 & +3.5 & 6.6 \\
\hline $\begin{array}{l}\text { Texaco, Harris et al } \\
\text { \#1 Brazor la } \mathrm{Co} \text {, Tex. }\end{array}$ & 122 & $2144-6740$ & 19 & 13 & -3.9 & 6.2 \\
\hline $\begin{array}{l}\text { Gen. Crude, P1. Bayou } \\
\text { \#1 Brazorla Co, Tex. }\end{array}$ & 218 & $1310-6910$ & 18 & 6 & +1.3 & 3.2 \\
\hline
\end{tabular}

Notes: 1. SP difference is measured between computer derived SP and SP value picked by author.

2. Blas with + sign indicates computer derived SP is too large.

3. Std. Deviation is computed relative to SP values picked by author. 
Attachment 1

Error Analysis, S.P. Calculation

$$
\begin{aligned}
& S . P .=K \log _{10}\left(\frac{R_{M F}}{R_{\omega}}\right)=\frac{K}{2.3} \ln e\left(\frac{R_{M F}}{R_{\omega}}\right) \\
& e^{\frac{2.3(S P)}{K}}=\frac{R_{M F}}{R_{\omega}} ; \quad R_{\omega}=R_{M F} e^{-\frac{2.3(S P)}{K}}
\end{aligned}
$$

$d R_{k}=e^{-\frac{2.3(S . P)}{k}} d R_{M F}+R_{M F}\left(\frac{-2.3}{K}\right) e^{-\frac{2.3(S . P .)}{K}} d(S P)+\frac{R_{M F}-2.3(S P)}{K^{2}} e^{\frac{-2.3(S P)}{K}} d K$

Divide by $R_{w}$ to get $\%$ error in $R_{w}$, get

$$
\frac{d R_{w}}{R_{w}}=\frac{d R_{M F}}{R_{\text {MI F }}}-2.3 \frac{d(S P)}{K}+\frac{2.3(S P)}{K} \frac{d K}{K}
$$

For a deep, hot well, $\mathrm{K}$ might be $100 \mathrm{MV}$ and SP might be a $100 \mathrm{MV}$. For this case, we see that a $5 \%$ error in $R_{M F}$ translates directly to a $5 \%$ error in $R_{w}$, and a 5 Mirror in SP translates to an $11.5 \%$ error in $R_{w}$, and a $5 \%$ error in $K$ (which defines the efficiency of the shale membrane) translates to an $11.5 \%$ in $R_{w^{*}}$

If all errors are acting together, our best estimate of $\mathrm{dR}_{\mathrm{w}}=\%$ error in $R_{w}$, is given by

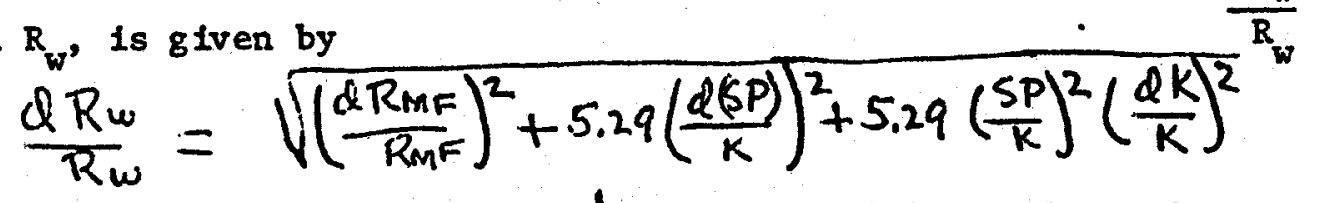

since the Individual errors of $\mathrm{dR}_{\mathrm{MF}}$, $d S P$, and $d K$ can be either + or - , with unknown sign.

117 
ATTACHMENT II

\title{
A NEW APPROACH TO THE DETERMINATION OF
} FORMATION WATER RESISTIVITY FROM THE SP LOG

by

\section{Podro Silva and Dr. Zaki Bessiouni \\ Potroleum Engineoring Department \\ Louisiana State University}

\begin{abstract}
Formation water resistivity $\left(R_{w}\right)$ is an important interpretation parameter. When water samples are available, $R_{w}$ is determined by direct measurement or calculated from the water chemical analysis. It is more practical, however, to estimate $R_{w}$ from the SP log. Poor correlations between the values obtained from water samples and those estimated from the SP are common.

The basic SP equation SP $=-K \log \left(a_{w} / a_{m f}\right)$ was examined, and two modifications deemed necessary. First, the chemical activities $a_{w}$ and $a_{m f}$ were directly expressed in terms of the resistivities $R_{w}$ and $R_{m f}$. The use of the artificially-defined equivalent resistivities, $R_{\text {we }}$ and $R_{m f e}$, is no longer necessary. Second, the parameter $K$ was found to vary with the shale resistivity $\left(R_{s h}\right)$. A new chart relating $S P$ to $R_{s h}, R_{m f}$ and $R_{w}$ was obtained.

The use of the new chart resulted in a tremendous fmprovement in the correlation between $R_{w}$ values obtained from water samples and those estimated from the SP log.
\end{abstract}

\section{INTRODUCTION}

The SP log has been extensively used to evaluate the formation water resistivity. The formation water resistivity $\left(R_{w}\right)$ is an important interpretation parameter used in the estimation of hydrocarbon saturation. It has been noted in several wells that have been tested in deep abnomally-pressured South Louisiana formations that logging calculations do not appear to give accurate representation of water resistivity. The discrepancy between $R_{w}$ values obtained from water samples and those estimated from SP logs could be due to the quality of water samples. Water samples recovered may exhibit dilution and contamination characteristics due to mixing with condensation water or drilling fluids. However, such discrepancy continues to exist when 
reliable water samples are available.

The purpose of the study reported in this paper was to examine the method traditionally used to calculate $R_{w}$ from the $S P \log$ and to develop a new calculation approach yielding more reliable $R_{W}$ values.

\section{TRADITIONAL APPROACH}

The method traditionally used to calculate $R_{w}$ from the $S P \log$ is based on the well known equation: 1

$$
S P=-k \log \frac{a_{w}}{a_{m f}}
$$

where:

$S P=S P$ log deflection in millivolts; corrected for bed thickness and other measurement environment,

$a_{w}=$ Activity of the formation water in gr-ion/liter,

$a_{m f}=$ Activity of the mud filtrate in gr-ion/liter,

$K=$ Coefficient which depends on the formation temperature $\left(K=61+0.133 T ; T^{\circ}{ }^{\circ} \mathrm{F}\right)$

Assuming that the mud filtrate and the formation water are pure $\mathrm{NaCl}$ solutions, one can relate solution activities and resistivities using experimental data, as shown in Fig. 1. In order to express this relation analytically, Gondouin, Texier, and simard ${ }^{2}$ introduced the concept of equivalent resistivity. The equivalent resistivity is inversely proportional to the activity. By the definition equation (1) becomes:

$$
S P=-K \log \frac{R_{\text {mfe }}}{R_{\text {we }}}
$$

where $R_{m f e}$ and $R_{\text {we }}$ are the mud filtrate equivalent resistivity and the formation water equilivalent resistivity, respectively. The relation between true and equivalent resistivities is given graphically by the chart of Fig. 2 Equation (2) has been extensively used to estimate $R_{w}$ from SP values.

Kharaka and co-workers ${ }^{3}$ reported detailed chemical analysis of several formation water samples from 7 oll and gas fields in the Lafayette. LA, area. 
These chemical analyses were determined using a new, reliable technique." These waters are predominantly $\mathrm{NaCl}$ with an average concentration of $\mathrm{Ca}$ and Mg less than $5 \%$ by weight. The water resistivity values of these samples were calculated using the technique proposed by Ucok, Ershaghi and Oihoeft. 5 The comparison of these values and those estimated from the corresponding SP $\log$ deflections using equation (2) resulted in Fig. 3. The discrepancy between SP-log-calculated values and chemical-analysis-calculated values is evident.

This discrepancy could be the result of one or both of the two assumptions which are implicit in equation (2). These two assumptions are:

1. Both formation water and mud filtrate are pure $\mathrm{NaCl}$ soultions.

2. The shale is a perfect membrane, i.e., one through which only cations can pass.

The purpose of this study is to:

1. Evaluate the effect of these assumptions on the calculated $R_{w}$ values.

2. Modify equation (2) to include the effect of salts other than $\mathrm{NaCl}$.

3. Modify equation (2) to take into account the non-ideal membrane nature of the shale.

\section{EFFECT OF SALTS OTHER THAN NaCI}

When the mud filtrate and/or the formation water contain solutes other than $\mathrm{NaCl}$, the problem becomes very complex. Gondouin and co-workers ${ }^{2}$, treating the case of solutions of mixtures of calcium, magnesium, and sodium chlorides, have arrived at the following expression:

$$
S P=-K \log \frac{\left(a_{\mathrm{Na}}+\sqrt{\left.a_{\mathrm{Ca}}+{ }^{a_{M g}}\right)_{\mathrm{W}}}\right.}{\left(a_{\mathrm{Na}}+\sqrt{\left.{ }^{\mathrm{a}} \mathrm{Ca}+{ }^{a_{\mathrm{Mg}}}\right)_{\mathrm{mf}}}\right.}
$$

where $\mathrm{a}_{\mathrm{Na}}$, a $\mathrm{Ca}$, and $\mathrm{a}_{\mathrm{Mg}}$ are the fonic activities of $\mathrm{Na}, \mathrm{Ca}$ and $\mathrm{Mg}$ in the formation water and in the mud filtrate. If the concentrations of $\mathrm{Na}, \mathrm{Ca}$ and * Mg fons are known, the total activity a of a solution, that is $\left(a_{\mathrm{Na}}+\right.$ $\left.\sqrt{{ }^{a} \mathrm{Ca}+{ }^{a}}\right)$, can be determined using the chart of Fig. 4.

Fig. 5 is a plot of formation water total activity $\left(a_{T}\right)_{W}$ versus water resistivity for the samples used to construct fig. 3. This plot shows a 
linear relationship and suggests that, for predominantly $\mathrm{NaCl}$ solutions where limited concentration of other salts is present, a relation of the form

$$
\left(a_{T}\right)_{w}=\frac{a}{R_{w}^{b}}
$$

exists between the activity and the resistivity. The a and b coefficients reflect the composition of the samples considered. For the present example, $a$ and $b$ are 0.0756 and 1.07 , respectively.

A similar expression can be developed for mud filtrates. Optimum values of the coefficients $a$ and $b$ can be obtained if the detalled chemical composition of the filtrates is available. In the absence of chemical analysis, mud filtrates will continue to be considered pure sodium chloride solutions. For pure $\mathrm{NaCl}$ filtrates with resistivities higher than $0.1 \mathrm{ohm} . \mathrm{m}$, the values of the coefficients $a$ and $b$ are 0.075 and 1 , respectively. These values are derived from the straight-line portion of the plot of Fig. 1.

Using the above results, equation (1) can be written in the modified form:

$$
S P=-K \log \alpha \frac{R_{m f}{ }^{B}}{R_{w}^{\gamma}}
$$

For the samples considered in the present study the coefficients $\alpha, \beta$ and $\gamma$ are $1.008,1$ and 1.07 , respectively.

The above suggested that equation (1) can be reduced to

$$
S P=-k \log \frac{R_{m f}}{R_{w}}
$$

in the following cases: (1) for predominantly $\mathrm{NaCl}$ formation waters and mud filtrates with limited $\mathrm{Ca}$ and $\mathrm{Mg}$ ions; and (2) for predominantly $\mathrm{NaCl}$ formation water in the absence of filtrate chemical analysis.

It should be noted that equation (6) was previously used before the introduction of the equivalent resistivity concept in 1956 by Goudouin.

Fig. 6 is a plot of $R_{w}$ values calculated, for the samples in consideration, using equation $(6)$ versus $R_{y}$ calculated from chemical analysis. The 
correlation between the two groups of values is still very poor, as the figure illustrates.

\section{NON-IDEAL MEMBRANE BEHAVIOR OF SHALES}

Equation (5) still assumes that shale formations behave ideally as cationic permeable membranes. Laboratory measurements with shale membranes cut from cores comonly show a potential different from that calculated for an ideal membrane. For non-ideal membranes, $K$ is a function of shale cation exchange characteristics. Unfortunately, cation exchange characteristics are seldom available. For the purpose of practical interpretation, $K$ should be related to an available shale electric property which would reflect shale membrane characteristics.

The only shale electric property readily available is the shale electric resistivity, $R_{s h}$, reported on a resistivity 109 . Several attempts were made to incorporate $R_{S h}$ in the SP expression. Fig. 7 is a plot of a hypothetical value $K_{T}$ of the coefficient $K$ calculated from equation (6) using $R_{W}$ values

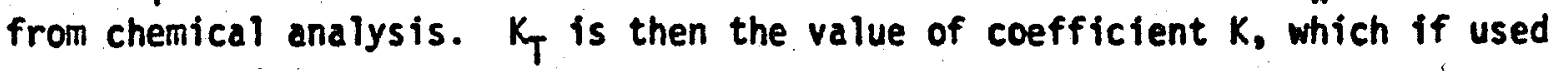
in equation (6), will yield a perfect agreement between $R_{w}$ values from the $S P$ and $R_{W}$ values from chemical analysis. Although no precise relationship can be inferred, it can be noticed that in general for a fixed $R_{s h}$ value, the value of $K_{T}$ tends to increase as (1) $R_{m f}$ decreases and (2) the SP reading increases.

In Fig. 8 , the same $K_{T}$ values are plotted against the ratio $R_{s h} / R_{m f}$. This was done in an attempt to include, in one dimensionless term. two of the parameters which seem to be important. Two interesting features can be noticed on this plot. Again, for a constant $R_{s h} / R_{m f}$ value, $K_{T}$ tends to increase as the SP reading increases. This is indicated by dotted-line trends. A trend defined by a solid line is also indicated. This trend could be related, according to the high SP values, to clean formations.

Fig. 7 and 8 show that coefficient $K$ is a function not only of the temperature, but also of the measurement environment as well. An expression for $K$ would be hard to obtain because of the many unknowns involved. However, a parameter exists that reflects all the possible variables controlling the SP phenomenon. Such a parameter is, of course, the SP reading itself. 
In fact, when the ratio $R_{m f} / R_{w}$ is plotted versus $R_{s h} / R_{m f}$, (Fig. 9) a well-defined relationship is obtained for each value of the SP. In order to present the correlation in a more convenient way, interpolated values of $F i g$. $g$ are plotted on Fig. 10, where $R_{m f} / R_{W}$ is plotted against the SP reading as a function of several $R_{s h} / R_{m f}$ values.

For comparison purposes, the correlation of Fig. 10 was superimposed on the graphical presentation of equation (2) representing the old interpretation approach, Fig. 11. The old and new interpretation approaches are close at righ $S P$ values. A considerable deviation is noticed at low SP values.

Using the correlation of Fig. 10 the $R_{w}$ values for the samples used in Fig. 3 were calculated and plotted in Fig. 12 versus the values calculated from the chemical analysis. An excellent agreement is clearly indicated, despite the fact that some of the data points were obtained in shaly formations. The examination of the raw data explained why points $1,2,3$, and 14 do not lie on the main trend:

Points 1 and 2: A discrepancy exists between the sample depth and the depth of the formation on the log, suggesting an erroneous data point.

Points 3: Formation was drilled with a high $\mathrm{Ca}$ content mud, which does not meet the consideration used to get equation $(6)$.

Points 14: No mud data were available for the zone of interest. Data from the preceding run were used.

\section{EXAMPLE OF APPLICATION}

$R_{w}$ values were calculated using the conventional and new approaches for the marked formation on the electric log shown in Fig. 13. The subject formation is a Miocene sand in the interval 12,870 to 12,910 ft. The results of these calculations and data obtained from chemical analysis are summarized in the table below:

\begin{tabular}{|c|c|c|}
\hline Method & $R_{w} \odot 75^{\circ} \mathrm{F}, \Omega . \mathrm{m}$ & $\%$ Deviation \\
\hline Water Analysis & 0.072 & $\cdots$ \\
\hline Conventional Approach & 0.170 & 136 \\
\hline $\begin{array}{l}\text { New Approach } \\
\text { (chart of Fig. 10) }\end{array}$ & 0.078 & 8 \\
\hline
\end{tabular}


This table clearly indicates the validity of the new approach and its superiority over the conventional interpretation technique.

\section{CONCLUSIONS}

1. If representative chemical analysis of mud filtrates and formation waters are available for a certain field, a relation of the form

$$
\frac{a_{w}}{a_{m f}}=\alpha \frac{R_{m f}^{B}}{R_{w}^{\gamma}}
$$

should be developed and used in future SP $10 \mathrm{~g}$ interpretation.

2. In the absence of detailed chemical analysis of mud filtrates, the following simple relation

$$
\frac{a_{w}}{a_{m f}}=\frac{R_{m f}}{R_{w}}
$$

is valid for all practical purposes.

3. The traditional SP equation

$$
S P=-k \log \frac{a_{w}}{a_{m f}}
$$

which assumes ideal membrane behavior of shales where $K$ is only temperature dependent, yields inaccurate values of $R_{W}$.

4. To account for the non-ideal membrane behavior of shales, $K$ should be expressed in terms of $R_{s h}, R_{m f}$ and $R_{w}$. A new relation giving $S P$ as a function of $R_{s h}, R_{m f}$ and $R_{w}$ was established, Fig. 10. The use of this new correlation resulted in a tremendous improvement of the accuracy of $R_{W}$ values, as indicated by their excellent agreement with values obtained from chemical analysis. 


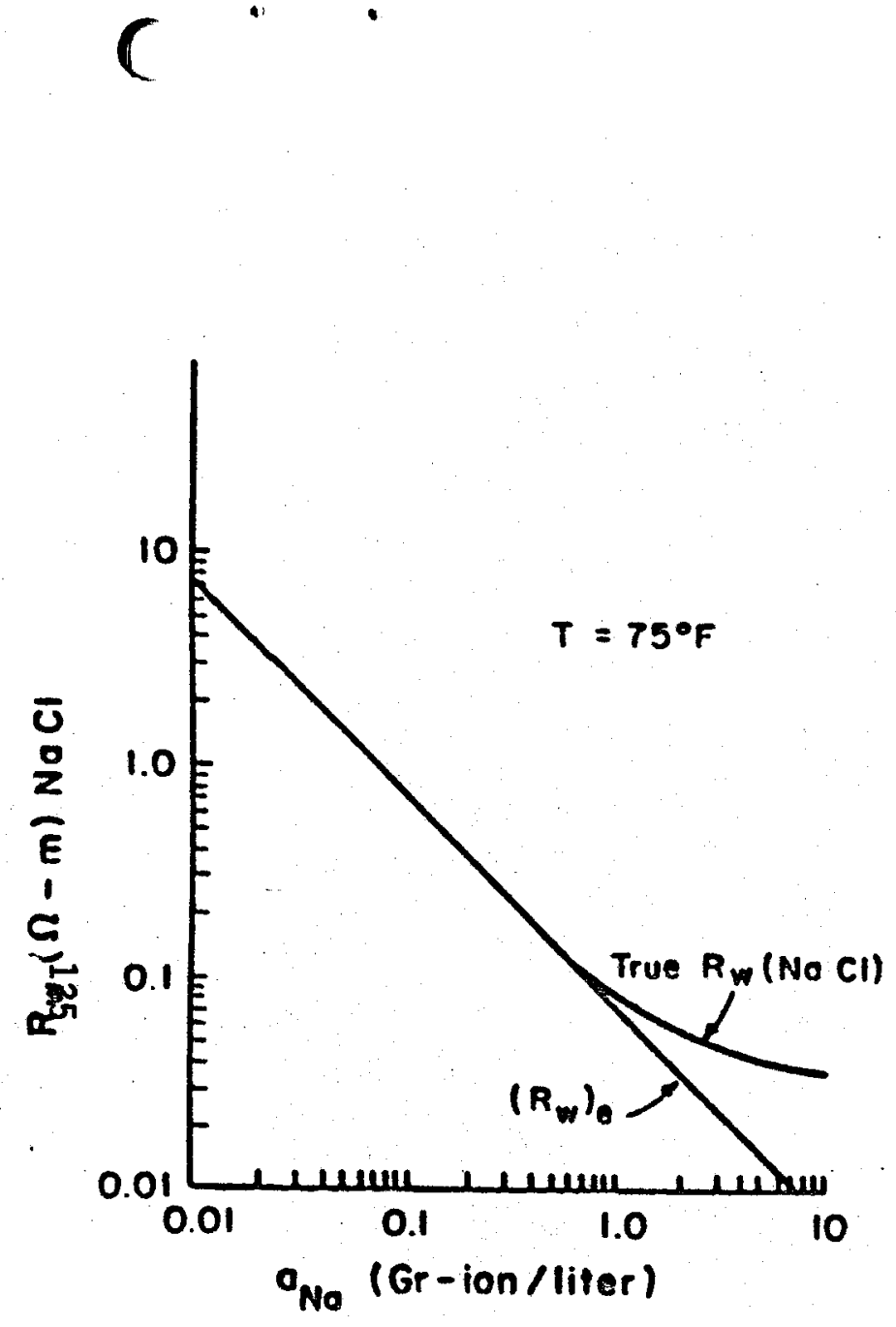

Fig. 1

Definition of the equivalent water resistivity term. (After Gondouin, Tixier, and Simard ${ }^{2}$.)

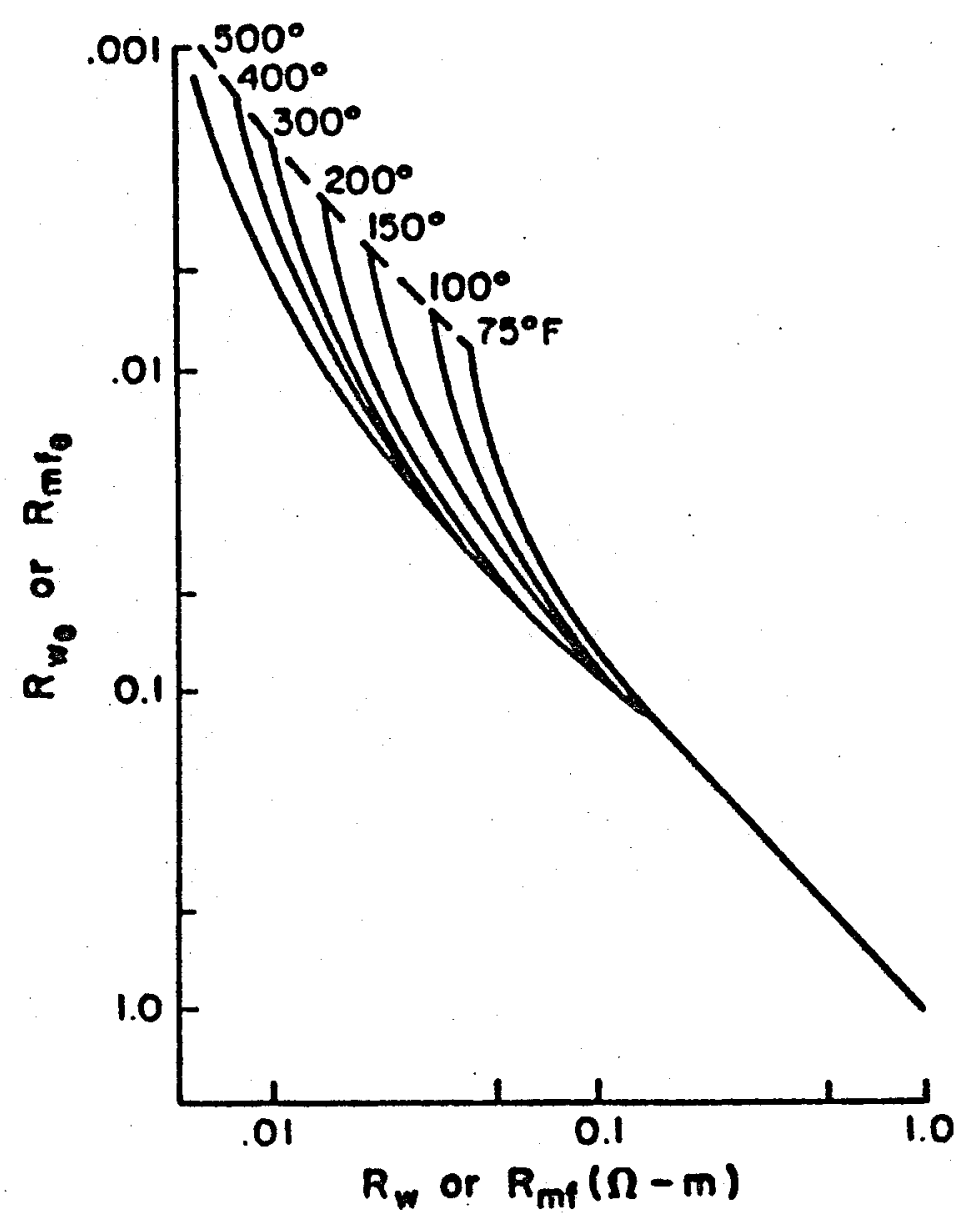

Fig. 2

Relationship between equivalenc and actual resistivities for formation waters and mud
filtrates. (After Gondouin, Tixier, and Simard ${ }^{2}$ ). 


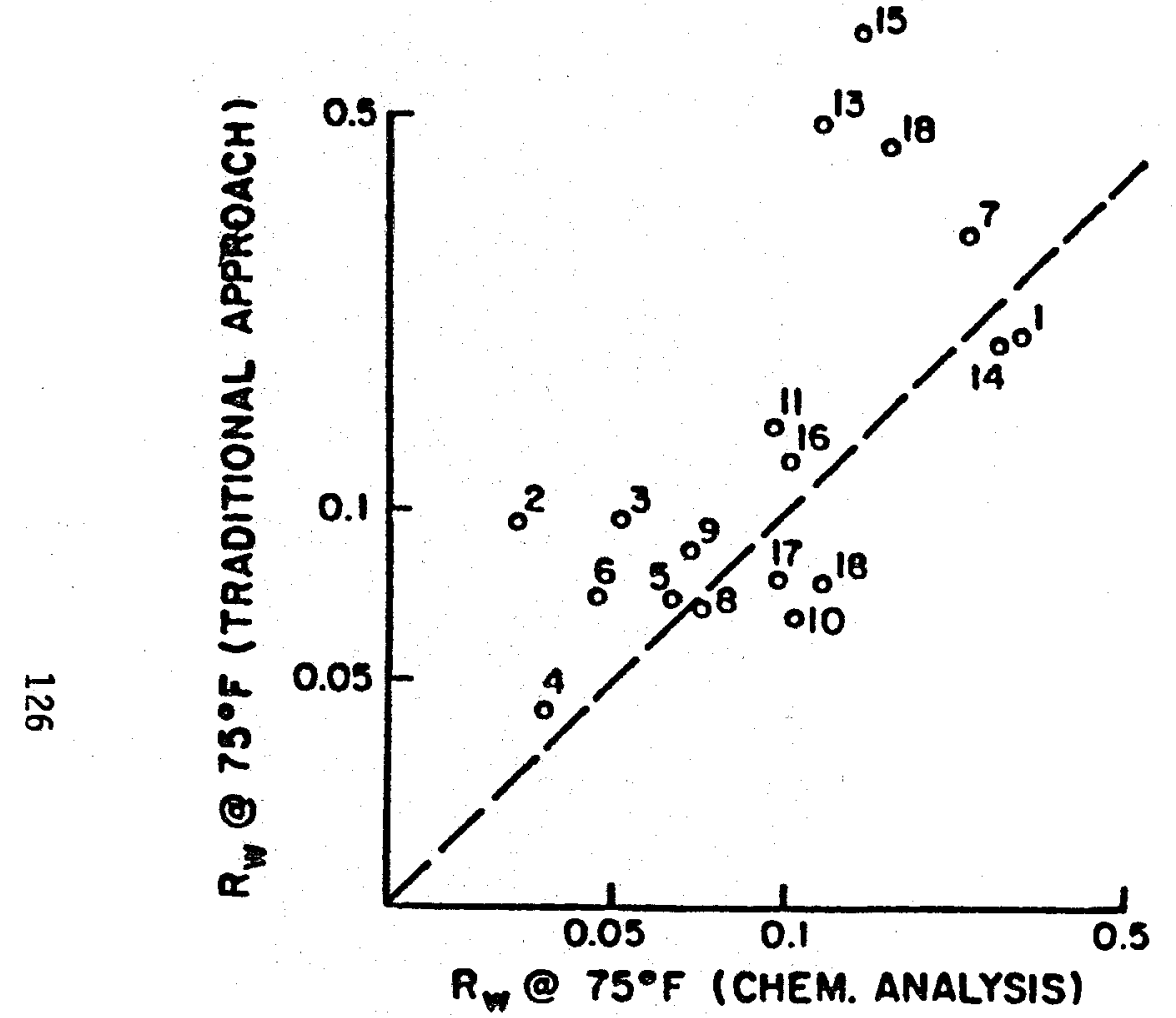

Fig. 3

Comparison of the $R_{W}$ values calculated with eq. (1) and those determined from the chemical analysis.

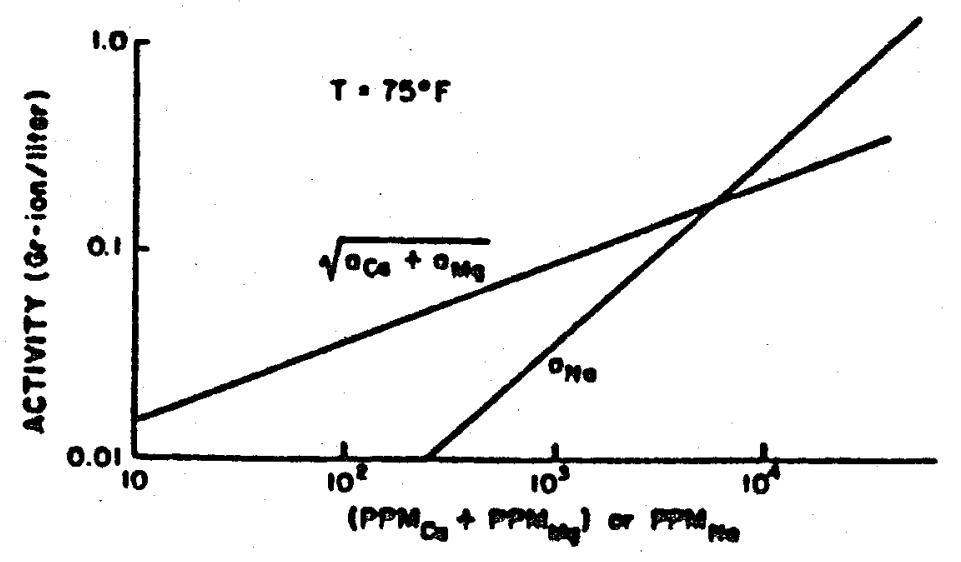

Fig. 4

Activity as a function of the $\mathrm{Na}, \mathrm{Ca}$, and Mg concentration. (Schlumberqer Log Interpretation/Vol. I - Principles). 


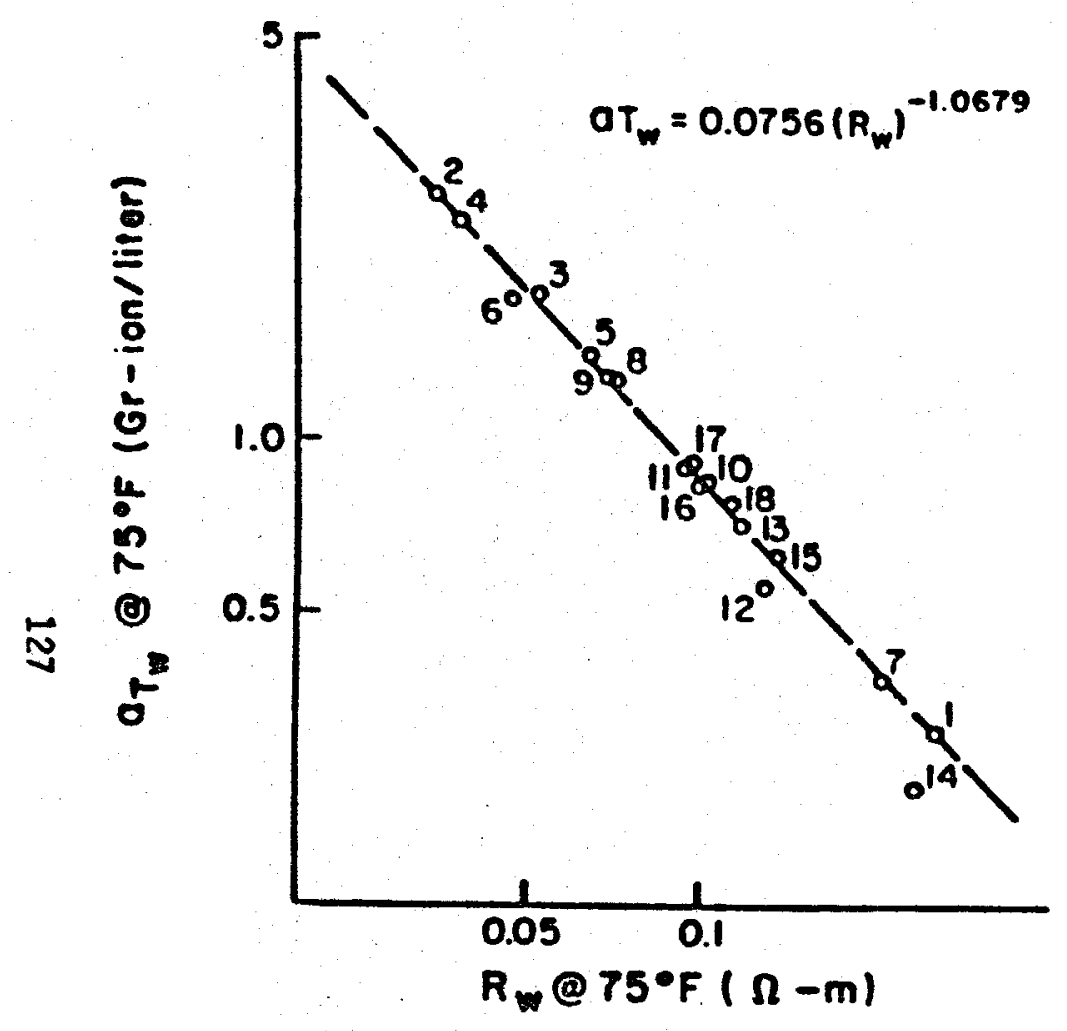

Fig. 5

Relationship between activity and resistivity for the analyzed data.

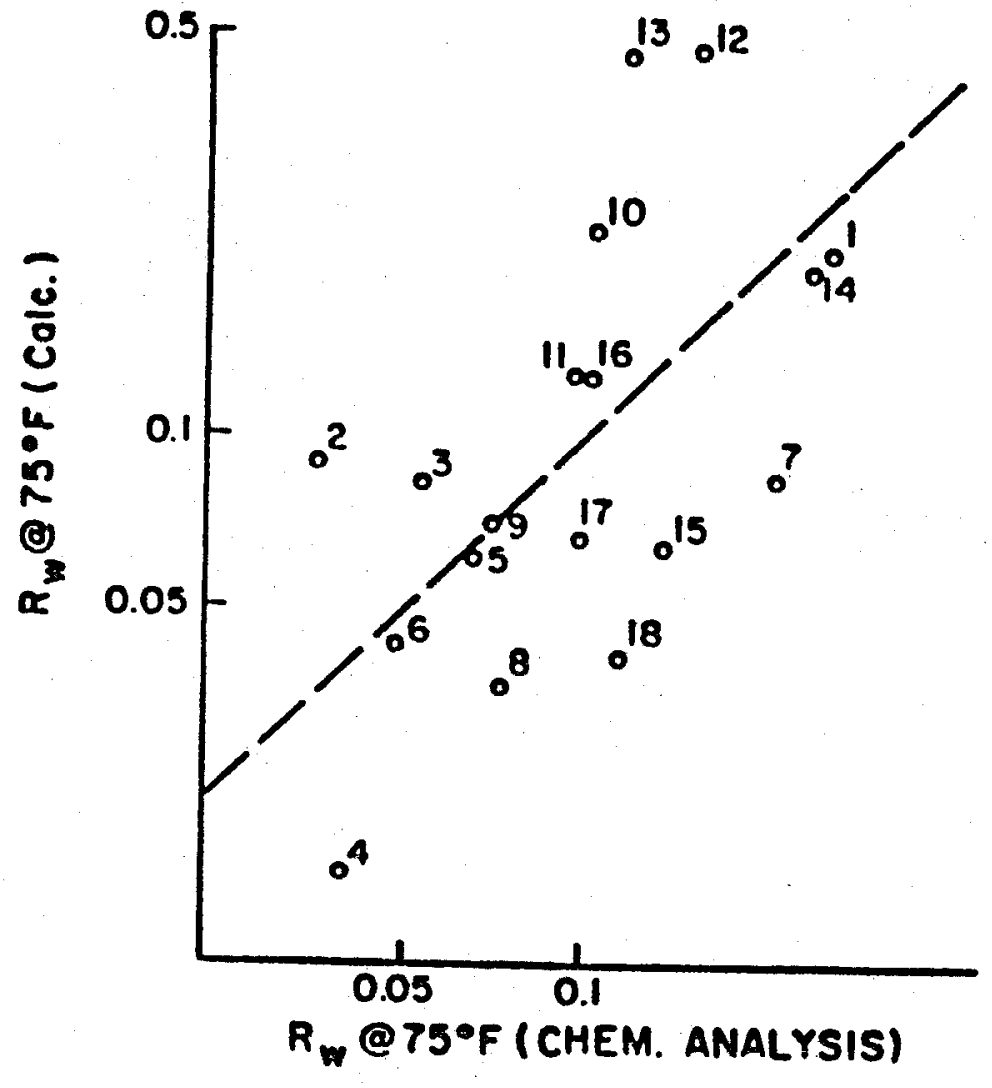

Fig. 6

Comparison of the $R_{w}$ values obtained with eq. (5) to those obtained from the chemical analysis. 


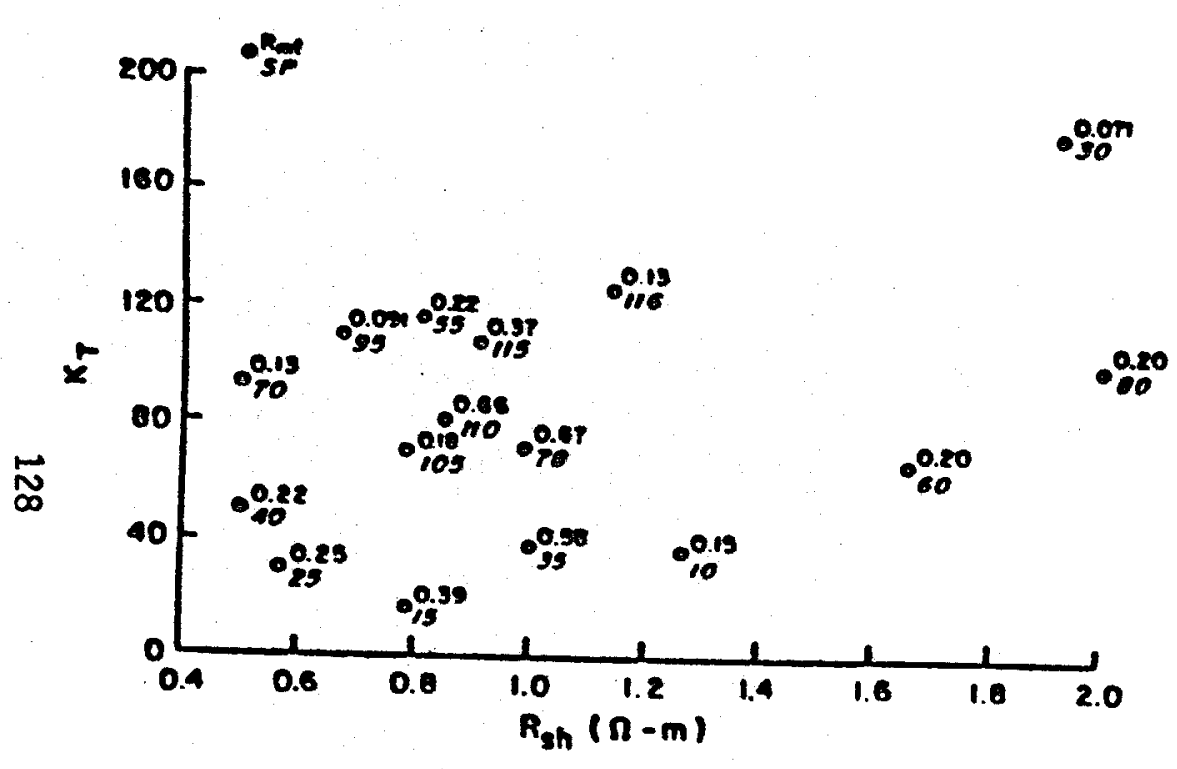

Fig. 7

Theoretical value of the coefficient $K_{T}$ as function of $R_{s h}, R_{m f}$, and $S P$.

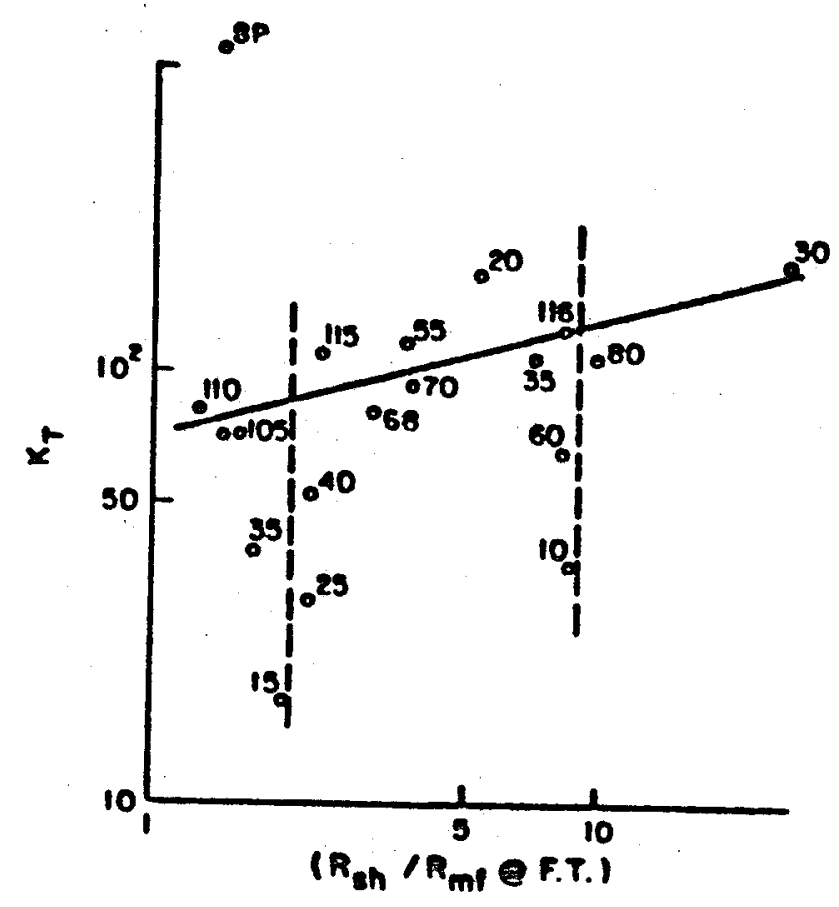

Fig. 8

$K_{T}$ as a function of the ratio $R_{s h} / R_{m f} \odot F$. T. and the SP value.

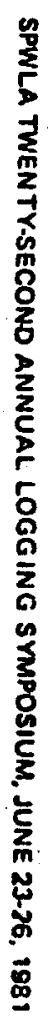




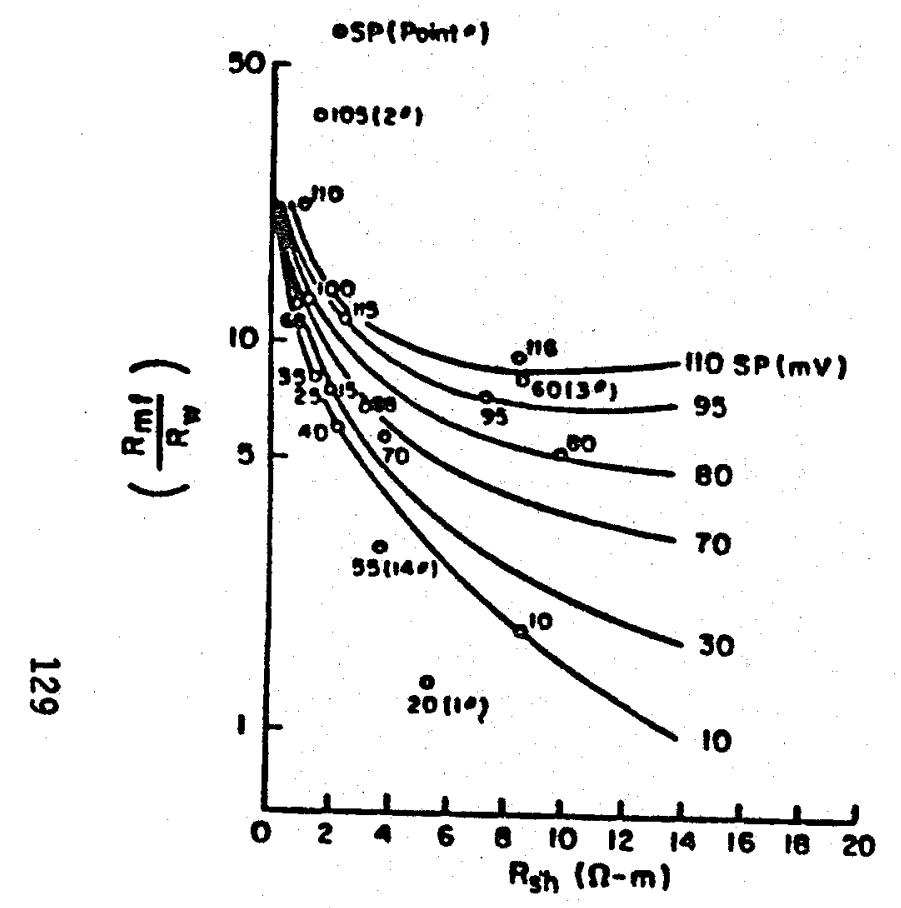

Fig. 9

Correlation between $\left(R_{m f} / R_{w}\right)$ e $75^{\circ} \mathrm{F}$ and $\left(R_{s h} / R_{m f}\right)$ P F.T. as a function of the $S P$ value.

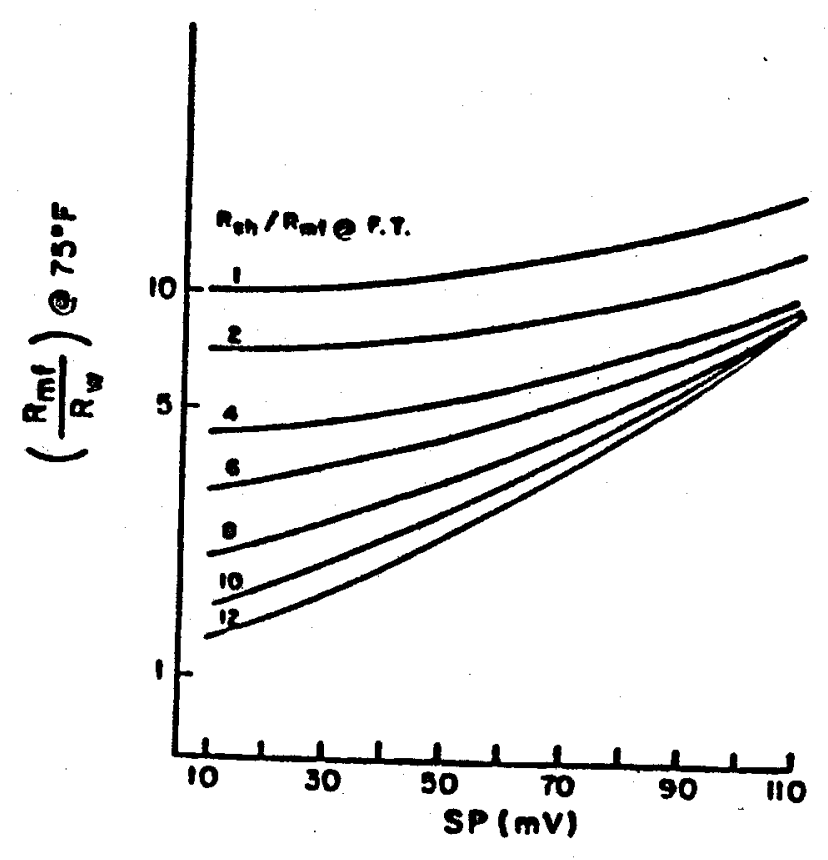

Fig. 10

Correlation between $\left(R_{m f} / R_{w}\right)$ o $75^{\circ} \mathrm{F}$ and the SP value as a function of the ratio $\left(R_{s h} / R_{m f}\right)$ F.T. 


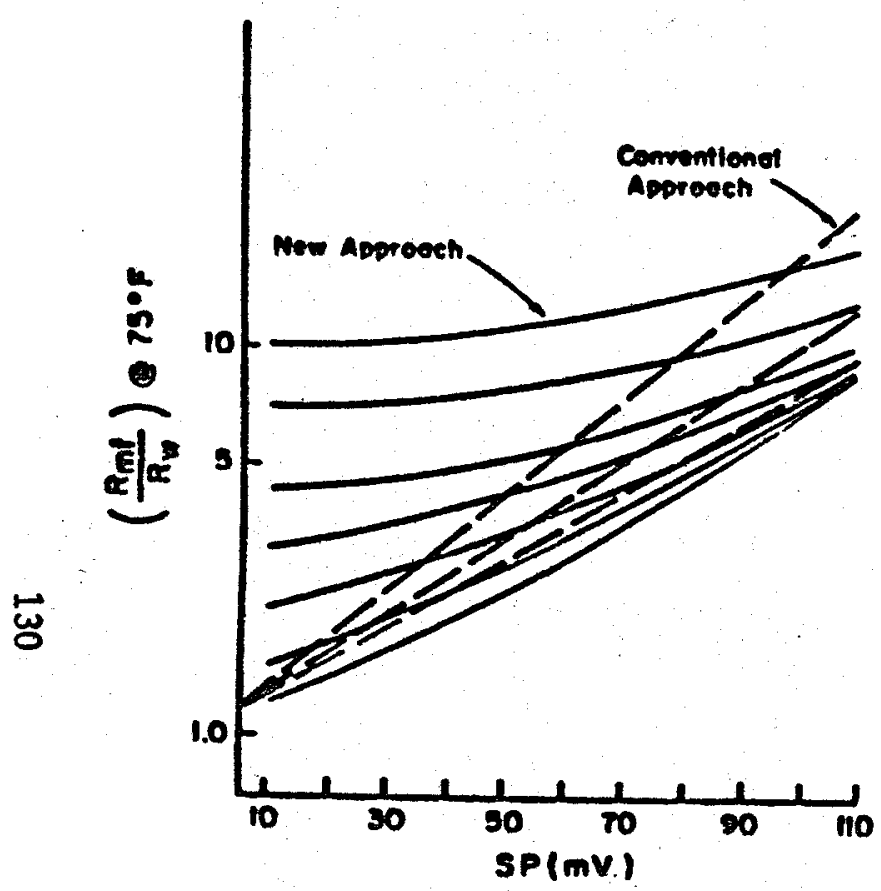

Fig. 11

Comparison between the oil and new approaches to determine $R_{w}$.

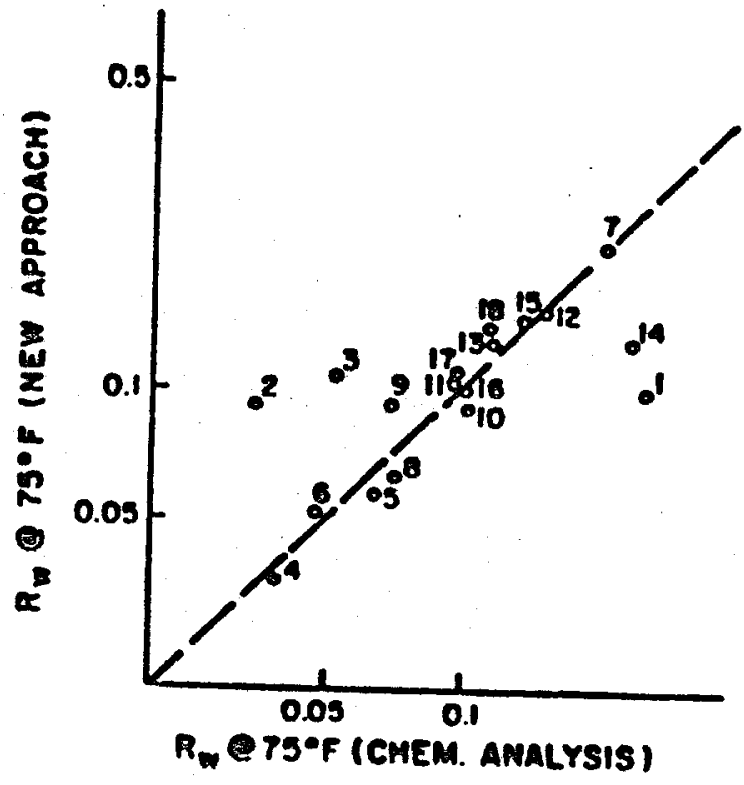

Fig. 12

Final results, Comparison of the $R_{w}$ values calculated using the new correlation (Fiq. 10) and the ones obtained from the chemical analysis. 


\section{Mell Data:}

Mell: Edna Delcambre 11

Fleld: Tigre zagoon

County: vermillion

state: Louisiana

Formation: Sand 3 (mlocene)

Interval: 12,070 to $12,910 \mathrm{ft}$

Themical Analygls Data:

rDS: $133,300 \mathrm{mg} / 1 \mathrm{t}$

calculated $R_{0}: 0.072 \mathrm{n.m} / 75^{\circ} \mathrm{F}$

jog Data:

$\vec{\omega}$
$: P=-60 m v$

$F_{\mathrm{nE}}=0.74$ e $82^{\circ} \mathrm{F}$

* sd Type: cucis

C. $=18.2 \mathrm{lb} / \mathrm{gal}$

But $=240^{\circ} \mathrm{P} e 14,160 \mathrm{ft}$

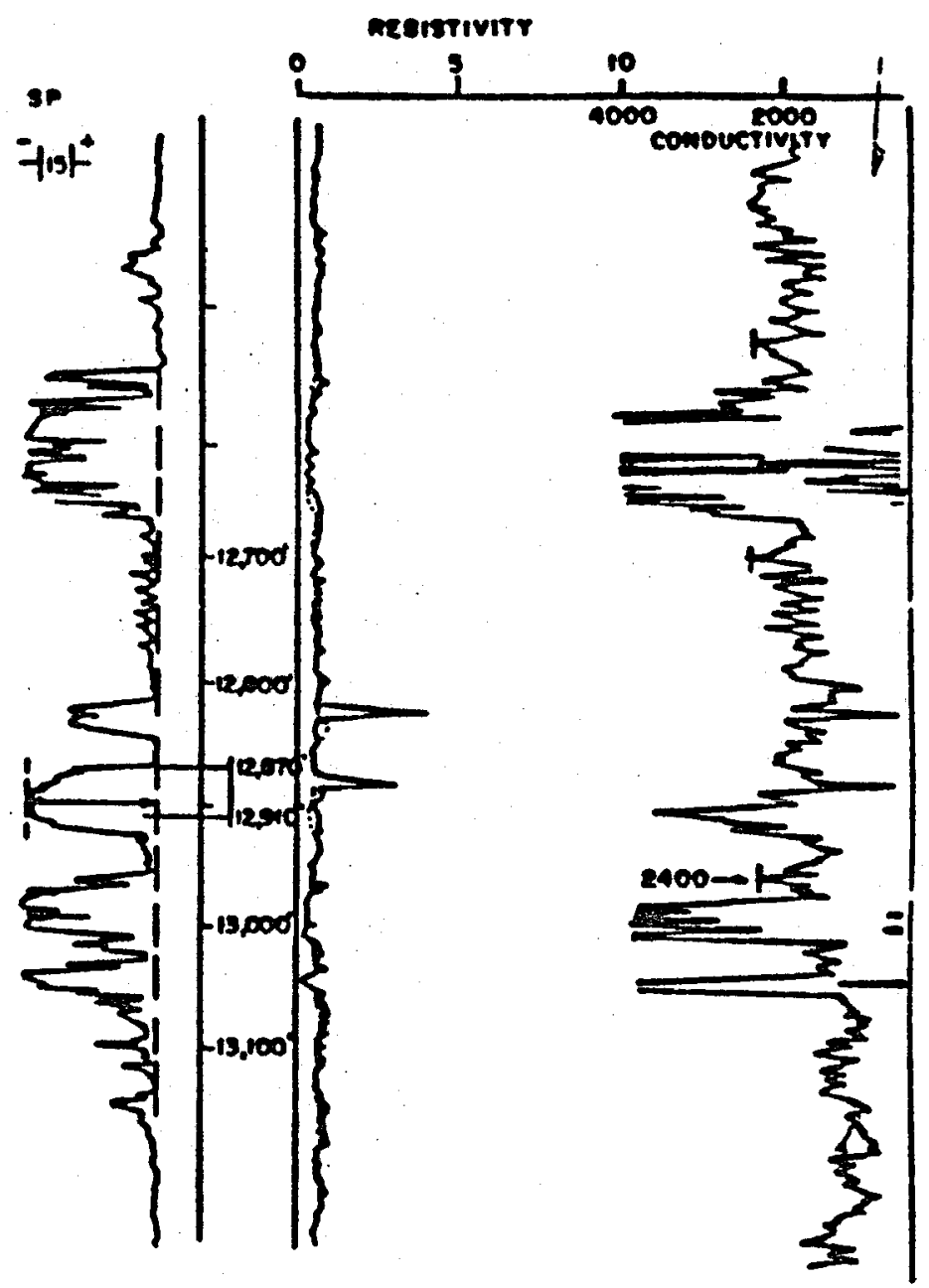

Example of Application 


\section{REFERENCES}

1. Wyllie, M. R. J.: "A Quantitative Analysis of the Electrochemical Component of the SP Curve", Jour. Pet. Tech. Vol. 1, 1949.

2. Gondouin, M., Tixier, M. P., and Simard, G. L.: "An Experimental Study of the Influence of the Chemical Composition of Electrolytes on the SP Curve", Jour. Pet. Tech., Feb. 1957.

3. Kharaka, Y. K., Brown, P. M., and Carathers, W. W.: "Chemistry of Waters in the Geopressured Zone Fron Coastal Louisiana -- Implications For the Geothermal Development", Geothermal Resources Council Transactions, Vol. 2, July 1978.

4. - Presser, T. S., and Barnes, I.: "Special Technques for Determining Chemical Properties of Geothermal Waters", U. S. Geological Survey Water Resources Inv. 22-74.

5. Ucok, H., Ershghi, J., and Olhoeft, G. R.: "Electrical Resistivity of Geotherma i Brines", Jour. Pet. Tech. April 1980.

\section{ABOUT THE AUTHORS}

Dr. Zakl Bassiouni is an Assistant Professor of Petroleum Engineering at Louisiana State University. He holds a B. S. degree in Petroleum Engineering from Cairo University, a diploma in geophysics from the French Petroleum Institute, and a Ph.D. from the University of Lille, France. Dr. Bassiouni is a member of SPWLA and SPE.

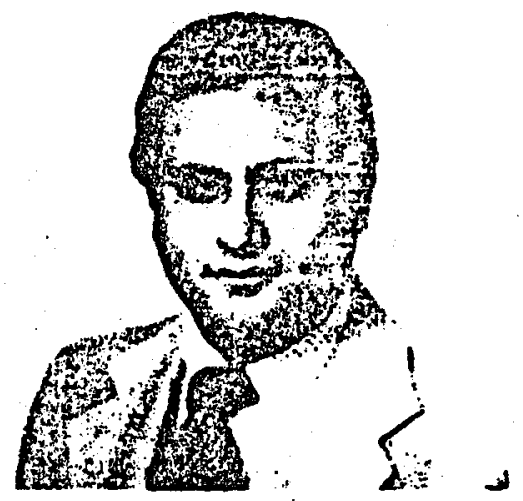

Pedro Sllva holds a B. S. degree in Petroleum Engineering from the University of Mexico. He is a Production Engineer with the Mexican Petroleum Institute, presently on leave of absence completing graduate work at Louisiana State University. 
Progress Report \#17, July 1981

Study of Log Derivęd Water Resistivity Data

in Geo Formations

Summary: Six additional cases have been calculated, four with 1 ime base muds, and two with lignosulfonate muds. (Sec table 1:) All cases were for low temperature (about $180^{\circ} \mathrm{F}$ ), and low mud weight (about $12 \mathrm{ppg}$ ), so there is some doubt as to whether they really $f$ it the high temperature, high mud weight tests we have considered previously. The application of the age correction does not help the salinity estimate for the two lignosulfonate cases of Table 1 . It appears that the age correction will be applicable only for hotter and higher pressure zones than those 1isted in table 1, and only for lignosulfonate muds (see Progress Report \#15).

A new method for estimating formation water salinity has been worked out which gives fairly good results for header values of $\mathrm{R}_{\mathrm{F}}>.4 \Omega \mathrm{M} \mathrm{C} 75^{\circ} \mathrm{F}$. The method has been applied to the 16 cases of lignosulfonate mud wells discussed in our paper (attached to P.R. \#15), plus tests 30 and 31 of Table 1 , which also used L. S. mud. A plot of ratio of true formation water salinity to conventionally calculated water salinity vs. header value of $\mathrm{R}_{\mathrm{MF}}$ e $75^{\circ} \mathrm{F}$ is shown in Fig. 1 . For RMF $>.4 \Omega \mathrm{M}$; the standard deviation of the plotted points from the trend 1 ine shown is $26,500 \mathrm{ppm}$. This is not too different from the $21,000 \mathrm{ppm}$ standard deviation achieved by the much more complicated procedures discussed in our paper. For $R_{M F}$ $<.4 \Omega \mathrm{M} @ 75^{\circ} \mathrm{F}$, the data are very erratic. These are nearly all very heavy muds. The heavy chemical treatment of these muds probably causes the low RMF values, and may lead to the large dispersion in this region of Fig. 1 .

We have applied Prof. Bassiouni's method to his own set of data, and find a standard deviation of $24,000 \mathrm{ppm}$ in calculated vs. observed salinities, using values of shale resistivity and other parameters picked by the author. The standard deviation using Bassiouni's parameters is $32,400 \mathrm{ppm}$. (See Figure 3.) There is some uncertainty about many of these tests because of questions concerning sample depth, excessive gas-water rat10, $R_{\mathrm{SH}}$ values, etc. However, the 24,000 ppm value for standard deviation is not too different from the 21,000 ppm value reported in our paper.

We plan to carry out a regression analysis on our data to improve the match of calculated and observed salinities, and to better define the remaining residual error.

Discussion: We have found 6 additional cases from the files of the Bureau of Economic Geology which appear to be reliable enough to use. All make more than 10 bbls. $\mathrm{H}_{2} \mathrm{O}$ per $10^{6}$ MCF gas, so the dilution of formation water by distilled water brought up as a vapor In the gas stream and condensed in the separator should not be greater than about $10 \%$. Data, and results of the salinity calculations, are shown in Table 1. Note that the wells are all low temperature (from $170^{\circ} \mathrm{F}$ to $201^{\circ} \mathrm{F}$, with average temperature of $181^{\circ} \mathrm{F}$ ), and low pressure (mud weights range from 11.3 - to $12.6 \mathrm{ppg} .$, with average of $11.9 \mathrm{ppg}$ ). By comparison, the 16 wells used as a data base for our paper had an average temperature of $254^{\circ} \mathrm{F}$, and an average mud weight of $16.2 \mathrm{ppg}$. We see that the 6 wells of Table 1 are definftely not in the temperature and pressure regime of the wells previously considered. Nevertheless the " $K_{F}$ " derfved water salinity matches the measured water salinity about as well. as the header, or the Gen. 7 , derived water salinities do. 
The attempt to get more information on a " $K_{F}$ " curve specifically applicable to 1 ime based muds mentloned in last month's progress report, was not very successful since all our mud weights are so low. For low mud weights, the data of Gen.7 are not too bad.

The age correction discussed in our paper, when applied to tests \# 30 and 31 of Table 1 (both drilled with 1 ignosulfonate muds) makes the calculated salinity much worse instead of better. We tentatively interpret this to mean that these wells were too $\operatorname{cool}\left(201^{\circ} \mathrm{F}\right.$ and $\left.170^{\circ} \mathrm{F}\right)$ and $/$ or too low pressure $(11.4$ and $11.3 \mathrm{ppg}$ mud wt.) to make this correction appropriate.

A new, simpler method of calculating formation water salinity has been devised which works fairly well for $R_{M F}$ (Header) $>.4 \Omega \mathrm{M}$ e $75^{\circ} \mathrm{F}$. Referring to $\mathrm{F} 1 \mathrm{~g}$. 1 , we plot the rat to of true salinity to conventionally calculated salinity vs. header $R_{M F} @ 75^{\circ} \mathrm{F}$. For $R_{M F}>.4 \Omega \mathrm{M}$ there seems to be a fairly good correlation between this ratio and $R_{M F}$ Below $R_{M F}=.4 \Omega M$, the data shows a tremendous disperston, and no correlation ts possible.

When $R_{M F}$ is plotted against mud weight, as in Fig. 2, we see first a generally rising trend of $R_{M F}$ as mud weight increases. Then, at around 14 to $16 \mathrm{ppg}$, the $R_{\mathrm{MF}}$ values fall rapidy as mud weight increases. We speculate that this decrease in ${ }_{M}$ as mud weight increases is due to the much heavier chemical treatment needed to control mud properties when drilling these high pressure zones. The Imco data referred to in previous progress reports also seems to indicate a general trend for decreasing $R_{M}$ (and hence of decreasing $R_{M F}$ ) as mud weight increases. See Fig. 8 of our paper, for example. (Prog. Report 非方.) The heavier chemical treatment of the mud implies that $R_{M F}$ is not a very good measure of Nat Ion activity in the mud filtrate, which is a basic assumption of the conventional calculation. This may account for the great scatter of the data at $\mathrm{R}_{\mathrm{MF}}<.4 \Omega \mathrm{M}$.

Whatever the reason for the $R_{\text {FF }}$ vs. mud weight behavior, Fig. 1 provides a simple method for est imating water salinity when $R_{M F}$ a $75^{\circ} \mathrm{F}>.4$ MM. The standard deviation of the 12 points meeting this condition, relative to a "best $f$ it" Iine, is $26,500 \mathrm{ppm}$. This is not very much larger than the 21,000 ppm std. dev. found using the much more complicated method discussed in our paper.

Using this simplifled method, I have not yet found a way to help the estimate by using the formation age.

Using logs and water data supplied to us by Prof. Bassioun1, we have applied his method to his data set. We get a standard deviation of $24,000 \mathrm{ppm}$ in calculated vs. observed salinities, when using values of shale resistivity, etc. picked by the author. Using Basslouni's values of shale resistivity, etc. the standard deviation is $32,400 \mathrm{ppm}$. (See F18. 3) Both values are not greatiy different from the 21,000 ppm std. deviation we found in our paper. Incidentally, the standard deviation for the Bassiouni data set for the conventional calculation of water salinity from the S.P. Is only $38,200 \mathrm{ppr}$, compared to 69,000 for the data set in our paper. Th1s difference probably results from the lower temperatures and pressures in the BassLoun 1 data set.

The relatively close agreement in standard deviation between Bassioun 1 and myself is surprising, since we picked different shale resistivities in a number of cases. Also, the overall rellability of this data set is questionable, due to uncertainties in sample depth, gas water ratlos, and 108 legibility. Point \#2 (which I excluded from the standard deviation calculation) is an extreme case of the poor data quality. This water sample is listed by Kharaka as being from 15,882! However the total depth of this well is only 15,810: Bassiouni analyzed a zone at 15680-710; and compared this with the Kharaka water data at 15882 ! 
We are going to try a regression analysis on our various data sets to see if we can improve the situation. We might speculate that the ratio

True Salinity

$\frac{\text { Calc. Salinity }}{\text { Calc }}=1$ if the calculation is perfect.

If it is not perfect (and

of course it never is) we should have

$\mathrm{R}=1+\mathrm{C}_{1} \mathrm{R}_{\text {MF }} \odot 75^{\circ} \mathrm{F}+\mathrm{C}_{2} P_{\text {MUD }}+\mathrm{C}_{3} \mathrm{~T}{ }^{\mathrm{o}} \mathrm{F}+\mathrm{C}_{4} \mathrm{~A} 10^{6} \mathrm{yrs} .+\mathrm{C}_{5} \mathrm{R}_{\text {SHALE }}$

where the $C_{1}^{\prime}$ 's indicate the relative contribution of $I^{\prime} t_{2}$ variable to the excess of $R$ over 1. 'The five variables shown (mud filtrate resistivity, mud weight, well temperature, formation age, and boundary shale resistivity) cover what seem the most 11 kely variables, but others could be used. In principle we will try to use statistical analysis to decompose the residual error from a given calculation method into error components resulting from specific known varlables. If regression analysis can give us good values for the $C_{1}^{\prime}$ 's, then we can solve the original equation for a better esimate of the true salinity.

H.F. Dunlap, Aug. 4, 1981

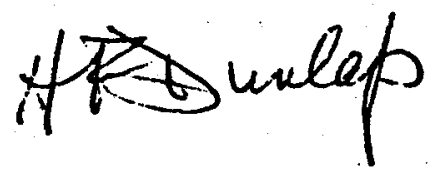


Table 1 - Measured SP Derived Water

Data from Geo Formations

\begin{tabular}{|c|c|c|c|c|c|c|c|c|c|c|c|}
\hline Test \# & $\begin{array}{l}\text { Well } \\
\text { Name }\end{array}$ & Locat ion & $\begin{array}{l}\text { Sand } \\
\text { Depth } \\
\text { ft. }\end{array}$ & $\begin{array}{l}\text { Well } \\
\text { Temp. } \\
\text { F }\end{array}$ & $\begin{array}{l}\text { Mud } \\
\text { Dens. } \\
\text { PPG }\end{array}$ & $\begin{array}{l}\text { Meas. } \\
\text { Salin. } \\
1000 \\
\text { PPM }\end{array}$ & $\begin{array}{l}\text { Calc. } \\
\text { Salin. } \\
\text { (Header) } \\
1000 \text { PPM }\end{array}$ & $\begin{array}{l}\text { Calc. } \\
\text { Salin. } \\
\text { (Gen 7) } \\
1000 \text { PPM } \\
\end{array}$ & $\begin{array}{l}\text { Calc. } \\
\text { Salin. } 1 \\
\left(\mathrm{~K}_{\mathrm{F}}\right) \\
\text { IO00. PPY }\end{array}$ & $\begin{array}{l}\text { Mud } \\
\text { Type }\end{array}$ & $\begin{array}{l}\text { Geol. } \\
\text { Age }\end{array}$ \\
\hline 26 & $\begin{array}{l}\text { Sun State } \\
\text { Tract } 288 \\
\# 6 \\
\end{array}$ & $\begin{array}{l}\text { Chambers Co. } \\
\text { Texas } \\
\text { Red Fish } \\
\text { Reef F1d. } \\
\end{array}$ & $\begin{array}{r}10,000- \\
116 \\
\end{array}$ & $176^{\circ}$ & 12 & 63 & 63 & 63 & 68 & Lime & Fr 10 \\
\hline 27 & $\begin{array}{l}\text { Sun State } \\
\text { Tract } 288 \\
\# 2 \\
\end{array}$ & $" 1 "$ & $\begin{array}{r}9334- \\
47 \\
\end{array}$ & $181^{\circ}$ & 11.9 & 142 & - & 115 & 190 & " & $"$ \\
\hline 28 & $\begin{array}{l}\text { Sun State } \\
\text { Tract } 307 \\
\# 1\end{array}$ & $1 "$ & $\begin{array}{r}10836- \\
46 \\
\end{array}$ & $177^{\circ}$ & 12.6 & 64 & 60 & 78 & 79 & " & $"$ \\
\hline 29 & $\begin{array}{l}\text { Sun State } \\
\text { Lse. } 288 \\
\# 1 \\
\end{array}$ & " " & $\begin{array}{l}9696- \\
9708 \\
\end{array}$ & $179^{\circ}$ & 12 & 85 & 58 & 70 & 78 & $"$ & $b_{11}$ \\
\hline 30 & $\begin{array}{l}\text { Sun State } \\
\text { Tract } 288 \\
\text { \#13 }\end{array}$ & $1 "$ & $\begin{array}{c}9730- \\
42 \\
\end{array}$ & $201^{\circ}$ & 11.4 & 88 & 85 & 79 & 90 & L.S. & $\begin{array}{l}\text { Mid } \\
\text { Frio } \\
\end{array}$ \\
\hline 31 & $\begin{array}{l}\text { Sun State } \\
\text { Tract } 288 \\
\# 11\end{array}$ & $"$ & $\begin{array}{r}8720 \\
-23 \\
\end{array}$ & $170^{\circ}$ & 11.3 & 160 & 81 & 79 & 81 & L.S. & $\begin{array}{l}\text { Upper } \\
\text { Frio } \\
\end{array}$ \\
\hline
\end{tabular}




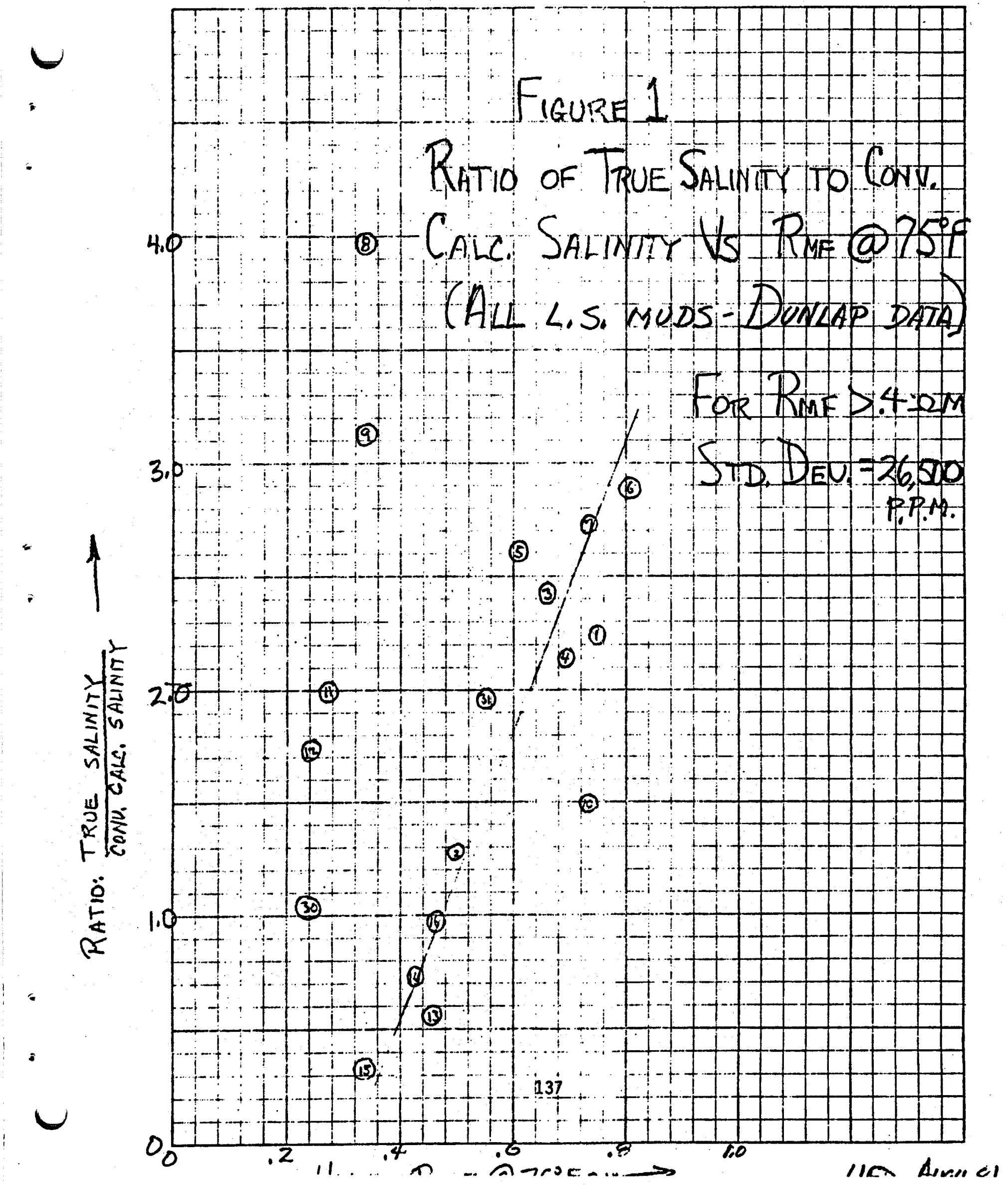




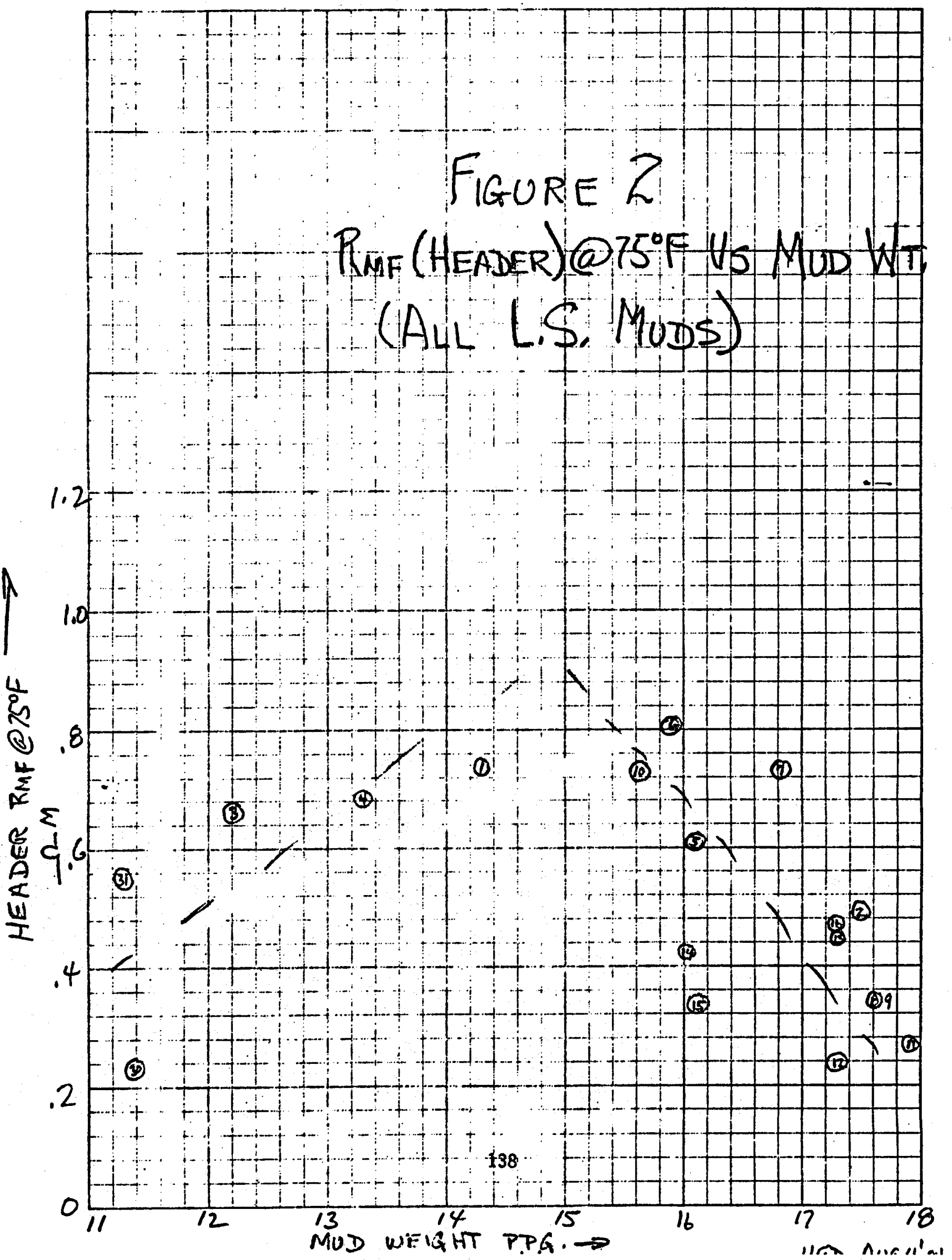




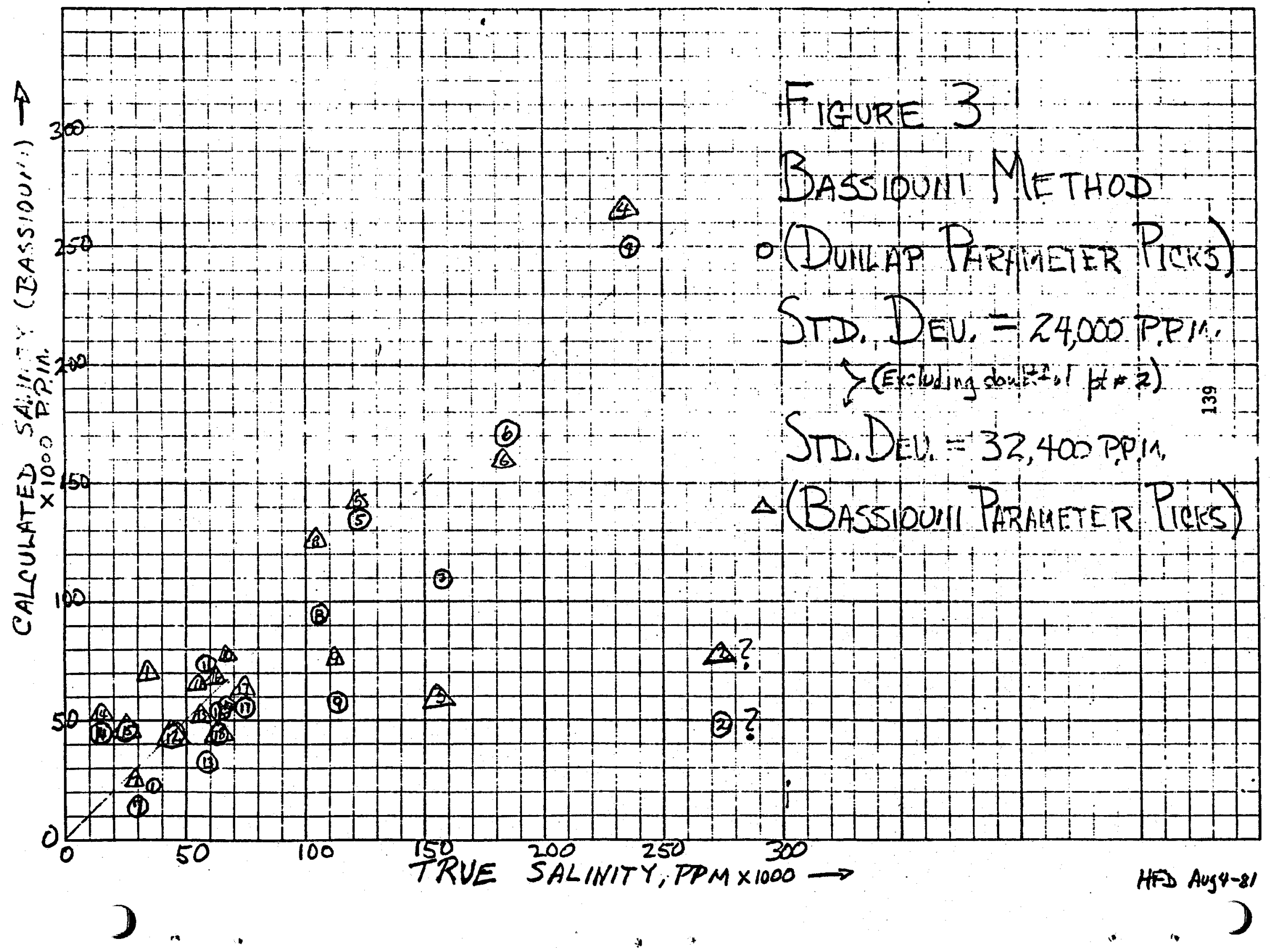




\title{
Progress Report \#18, August 1981 \\ Study of Log Deriyed Water Resistivity Data \\ in $\mathrm{GeO}^{2}$ Formations
}

\begin{abstract}
Summary: We have obtained data on the variation of both $R_{M}$ and $R_{M F}$ in a well drilled recently in Grimes County, E. Texas. Previousty we had only data on variation of $\mathrm{RM}_{\mathrm{M}}$ in drilling wells. The new data supports the indication of wide fluctuations in both $R_{11}$ and $R_{M F}$ as the well is drilled (see Fig. 1). In the upper section of the well, a series of high porosity sands occur. The spherically focused $\log$ (S.F.L.) measures primarily the invaded zone resistivity. Fig. 2 shows the SFL resistivity in these sands, which appears to roughly track the RuF variations. This supports our idea that it is the mud in the well when it is drilled, rather than when it is logged, that mainly determines the mud filtrate resistivity, and therefore, the $S P \operatorname{Tog}$ response.
\end{abstract}

We have carried out a number of regression analyses of our data to attempt to improve the match of observed and calculated salinities. We can reduce the standard deviation of our 16 well lignosulfonate mud data set from $21,000 \mathrm{ppm}$ (Salinity 3 calculation) to about $15,000 \mathrm{ppm}$ by this approach. For our 13 well, non lignosulfonate mud data set, we can reduce the standard deviation from about $20,000 \mathrm{ppm}$ (KF calculated salinities), to $6300 \mathrm{ppm}$ by this approach. If we use conventionally calculated (Gen 7) salinities, the standard deviation drops from $32,000 \mathrm{ppm}$ to $14,000 \mathrm{ppm}$ by using regression analysis.

We have given some thought to possible future work on this problem. These ideas are set out in Appendix 1.

Discussion: We have been fortunate in obtaining data on both RM and RMF, taken about every 15 hrs in a drilling well in Grimes County, Texas. The mud was lignosulfonate, 9 to $9.5 \mathrm{pd} / \mathrm{gal}$., formation pressures were hydrostatic, and temperature was moderate (max. well temperature $09500 \mathrm{ft}$ was $214^{\circ} \mathrm{F}$ ). Fig. 1 shows the record of $R_{M}$ and $R_{M F}$ (both $075^{\circ} \mathrm{F}$ ), plus mud weight, vs depth. In this rather high resistivity mud system, it is interesting to note that $R_{M F}>R_{M}$. Normally we expect $R_{M}>R_{M F}$, due to the presence of nonconducting solids (Barite, etc.) in the mud. However when the mud is quite fresh (resistivity high), the surface conductivity along the interface between the mud solids and mud liquid more than makes up for the volumetric effect of the mud solids in blocking current flow. Fig. 1 shows large variations in both $R M$ and RMF as the well is drilled, even though the mud weight is not changing substantially.

Fig. 2 shows a plot of RMF variations, plus spherically focussed log (S.F.L.) readings of invaded zone resistivity in a series of shallow, high porosity sands (middle and lower Wilcox ?) in this well. Note that the generally declining RMF values between 3000 and $5000 \mathrm{ft}$ are tracked fairly well by the S.F.L. invaded zone resistivity readings. Below $5000 \mathrm{ft}$ there are almost no sands so it is impossible to carry the comparison deeper. However this data does seem to support our idea that most of the mud filtrate is lost when the sand is drilled, and that the resistivity of the invaded zone should more nearly reflect the RMF at time of drilling instead of RMF at time of logging. Of course, there are variations in porosity and formation factor from sand to sand, 
so a perfect correlation of invaded zone resistivity with RMF should not be expected.

We have carried out a series of regression analyses on our various data sets to try to improve our water salinity prediction, and to estimate what variables contribute most to our residual error. The basic equation we have used for the 16 test lignosulfonate mud data set discussed in our paper is:

$$
\begin{aligned}
V_{8}=\text { True Salinity }= & C_{1} R_{M F}+C_{2} P_{m}+C_{3} T_{\text {OF }}+C_{4} A_{10^{6}} \text { yrs } \\
& \left.+C_{1} C_{S H} R_{S C} \text {. Sal.; or S.P. }\right\}+ \text { Constant }
\end{aligned}
$$

where

$$
\begin{aligned}
R_{M F} & =\text { Resis, of mud filtrate, } \Omega M=V_{1} \\
P_{M P} & =\text { mud density, pd/gal. }=V_{2} \\
T_{O F} & =\text { Well temperature at formation depth, }{ }^{\circ} F=V_{3} \\
A_{10^{6}} \text { yrs } & =\text { Formation age, } 10^{6} \text { yrs }=V_{4} \\
R_{S H} & =\text { Resistivity of bounding shales, } \Omega M=V_{5}
\end{aligned}
$$

For the term in brackets; if we use conventionally calculated salinity, in $1000 \mathrm{ppm}$, we would have $\mathrm{C}_{6} \mathrm{~V}_{6}$; if we use a Salinity 3 calculation, in $1000 \mathrm{ppm}$, we would have $C_{7} V_{7}$; if we use only the $S P$ (in millivolts) we would have $C_{9} V_{9}$. The true salinity, in $1000 \mathrm{ppm}$, we have defined as $V_{8}$.

With the assistance of Mr. Eddie Parker, we have used the SPSS (Statistical Package for Social Science) program on the University computer to carry out the regressions. Results are shown in Table 1. We see that when we do the regression analysis using conventionally calculated salinities, $v_{6}$, we can roughly cut the standard deviation nearly in half, from 69,000 ppm to about 39,000 ppm. Further, it doesn't seem to matter much whether we use the conventionaliy calculated salinity, the S.P. value, or (and this is a shocker) neither in the regression. The standard deviation is about the same at 38,500 to $38,700 \mathrm{ppm}$ whether either or none of these is included.

If we work with Salinity 3 values, $V_{7}$, calculated as outlined in our paper, and use the full regression equation with $V_{7}$, we can reduce the standard deviation a little, from $21,000 \mathrm{ppm}$ to $15,200 \mathrm{ppm}$. None of the variables $v_{1}$ through $v_{5}$ appears to be of overriding importance. If we drop them from the equation one at a time, we see from Table 1 that the importance, as measured by the increase in standard deviation when a variable is dropped, is in the order $V_{4}=$ Age; $V_{3}=T_{O F} ; V_{5}=R_{S H} ; V_{1}=R_{M F}$, and $V_{2}=P_{m}$, with $V_{4}=$ Age being the most important variable.

In Table 2 , we show values for the constants $C_{1}+C_{g}$ in the various regression equations.

For the 13 cases of nonlignosulfonate muds, we have carried out a similar regression analysis. The basic equation is the same as (1), except that the conventionally calculated salinity is usually done with the Gen 7 correlation rather than using a $\log$ header value for RMF, since most of these wells were drilled before RMF was routinely recorded on the header. Also, the Salinity 3 calculation (which we have pretty well shown not to be applicable to the nonilgnosulfonate muds) is replaced by a "KF Salinity" with the RMF value derived from a $K_{F}$ curve appropriate to the mud type. (See Fig. 1, Sixth Progress Report, 141 
August 1980). I.E. we define $V_{7}$ as the "KF salinity", and use all other variables as previously defined. Results are shown in Table 3.

We see that the standard deviation for the conventional calculation is $31,600 \mathrm{ppm}$. This can, as before, be cut about in half by use of the regression euqations, to about $14,000 \mathrm{ppm}$. The standard deviation for the $K_{F}$ calculation is 19,600 ppm. This can be considerable reduced, to about 6000 to $7000 \mathrm{ppm}$, by use of the regression equations. Here again, no one variable is of overriding importance. In fact, it appears we could drop $V_{3}=$ Temperature as a variable without loss of accuracy. For the lignosulfonate data set, recall that $V_{3}$ was the second most important variable.

Table 4 shows values for constants in the various regression equations for the nonlignosulfonate muds.

A word of caution is desirable here. Both data sets are small; 16 tests for the L.S. muds; 13 tests for non L.S. muds. The fits to the data using regression analysis are undoubtedly better than the fit would be if the equations using constants shown in Tables 2 \& 4 were applied to a second sample of data of similar size. Much more data is needed before the regression equations can be used with a great deal of confidence. In the absence of such data, they still represent the best estimate of the formation water salinity which is presently available.

I was requested to give some thought to future effort on this problem (after Nov. 1, 1981). Results are shown in Appendix 1 . There is some doubt that I will be involved after November 1 due to a conflict between Social Security laws, Income Tax laws, and my 65th birthday.

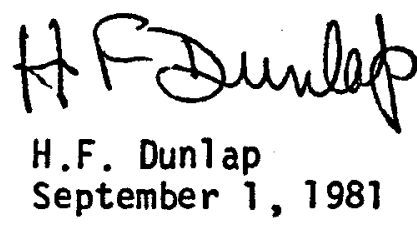




\section{Table 1}

Regression Analysis Results, Lignosulfonate Muds

\begin{tabular}{|c|c|c|}
\hline Regression \# & Variables Used in Regression & Std. Dev $\underset{(\mathrm{ppm})}{\text { of Calc. Sal. }}$ \\
\hline - & Conventional salinity calculation from S.P. $\log =V_{6}$ & 69,000 \\
\hline (1) & $v_{6}$ plus all variables in equ. (1) except $v_{7}$ and $v_{9}$ & 38,500 \\
\hline (2) & Same as $(1)$ except replace $v_{6}$ by $v_{9}$ (the S.P.) & 38,500 \\
\hline (3) & Same as ( 1 ) except drop $V_{6}$ & 38,700 \\
\hline - & Salinity 3 calculation, as outlined in our paper $=v_{7}$ & 21,000 \\
\hline (4) & Same as ( 1 ) except replace $v_{6}$ by $v_{7}$ (Salinity 3 ) & 15,200 \\
\hline (5) & Same as (4) except drop $V_{2}=\rho_{m}$ & 15,600 \\
\hline$(6)$ & Same as (4) except drop $v_{1}=R_{M F}$ & 15,730 \\
\hline (7) & Same as (4) except drop $V_{5}=R_{S H}$ & 15,850 \\
\hline (8) & Same as (4) except drop $V_{3}=T_{O F}$ & 16,100 \\
\hline (9) & Same as (4) except drop $V_{4}=A g e$ & 16,250 \\
\hline$(10)$ & Same as (4) except drop both $V_{2}$ and $V_{3}=\rho_{m}$ and $T_{0 F}$ & 17,100 \\
\hline
\end{tabular}


Table 2

Regression Equation Constants, Lignosulfonate Muds

\begin{tabular}{c|c|c|c|c|c|c|c|c|l}
\hline $\begin{array}{c}\text { Regression \# } \\
\text { from Table i) }\end{array}$ & $c_{1}$ & $c_{2}$ & $c_{3}$ & $c_{4}$ & $c_{5}$ & $c_{6}$ & $c_{7}$ & $c_{9}$ & Constant \\
\hline$(1)$ & 158 & -.067 & 1.26 & 4.95 & -83.6 & .549 & - & - & -405 \\
$(2)$ & 167 & -1.24 & 1.42 & 5.17 & -94.4 & - & - & -.006 & -399 \\
$(3)$ & 166 & -1.23 & 1.42 & 5.17 & -94.3 & - & - & - & -399 \\
$(4)$ & 63 & 4.1 & .322 & 2.01 & -20.3 & - & .772 & - & -209 \\
$(5)$ & 43.1 & - & .381 & 1.64 & -18.8 & - & .759 & - & -136 \\
$(6)$ & - & .792 & .156 & .580 & -6.49 & - & .817 & - & -52.2 \\
$(7)$ & 39.9 & 3.67 & .114 & .761 & - & - & .826 & - & -124 \\
$(8)$ & 39.2 & 5.5 & - & .923 & -2.46 & - & .84 & - & -128 \\
$(9)$ & 23.3 & 2.41 & .112 & - & .42 & - & .87 & - & -66.5 \\
$(10)$ & 4.07 & - & - & .10 & 4.57 & - & .838 & - & -1 \\
\hline
\end{tabular}




\section{Table 3}

Regression Analysis Results, Non-Lignosulfonate Muds

\begin{tabular}{|c|c|c|}
\hline Regression \# & Variables Used in Regression & Std. Dev $\underset{(\mathrm{ppm})}{\text { of Calc. Sal. }}$ \\
\hline - & Conventional (Gen 7) Calculation from S.P. Log $=V_{6}$ & 31,600 \\
\hline (1) & $v_{6}$ plus all variables in equ. ( 1 ) except $v_{7}$ and $v_{9}$ & 13,700 \\
\hline (2) & Same as $(1)$ except replace $V_{6}$ by $V_{9}$ (the S.P.) & 14,000 \\
\hline (3) & Same as $(1)$ except drop $V_{6}$ & 16,600 \\
\hline - & $K_{F}$ Salinity (= Salinity 1 , as outlined in our paper) & 19,600 \\
\hline (4) & Same as $(1)$, except replace $V_{6}$ by $V_{7}\left(K_{F}\right.$ Salinity) & 6,300 \\
\hline$(5)$ & Same as (4) except drop $V_{3}=T_{O F}$ & 6,300 \\
\hline (6) & Same as (4) except drop $v_{1}=R_{M F}$ & 6,500 \\
\hline (7) & Same as (4) except drop $V_{2}=\rho_{m}$ & 6,500 \\
\hline (8) & Same as (4) except drop $V_{4}=$ Age & 6,500 \\
\hline (9) & Same as (4) except drop $V_{5}=R_{S H}$ & 7,500 \\
\hline
\end{tabular}


Table 4

Regression Equation Constants, Non-Lignosulfonate Muds

\begin{tabular}{c|c|c|c|c|c|c|c|c|c}
\hline $\begin{array}{c}\text { Regression } \\
\text { (from Table 3) }\end{array}$ & $c_{1}$ & $c_{2}$ & $c_{3}$ & $c_{4}$ & $c_{5}$ & $c_{6}$ & $c_{7}$ & $c_{9}$ & Constant \\
\hline$(1)$ & -41.1 & -.24 & -.27 & 1.10 & -25.8 & .51 & - & - & 113 \\
$(2)$ & -54.6 & -3.2 & -.08 & .71 & -26.7 & - & - & .39 & 154 \\
$(3)$ & & & & & & & & & \\
$(4)$ & -13 & -1.3 & .007 & .32 & -10.6 & - & .50 & - & 59 \\
$(5)$ & -13.2 & -1.2 & - & .32 & -10.6 & - & .50 & - & 59 \\
$(6)$ & - & -2.1 & .033 & .10 & -11.8 & - & .50 & - & 64.7 \\
$(7)$ & -17.9 & - & -.053 & .38 & -8.64 & - & .52 & - & 50.0 \\
$(8)$ & -7.52 & -1.55 & .012 & - & -10.1 & - & .51 & - & 67 \\
$(9)$ & -13.8 & -6.0 & .093 & .74 & -31.8 & - & - & - & 160 \\
\hline
\end{tabular}


Appendix 1

Status of $\log$ Derived Water Salinity

Work, and Possibilities for Future Work

Problem: Predictions of water salinity from S.P. logs using conventional methods are usually too low in geothermal, geopressured wells of the Texas-Louisiana Gulf Coast. The underestimation of salinity leads to an overestimation of methane solubility, and hence, an overestimation of potential gas production from geothermal wells.

Status: Work during the last year and a half has led to an improved method of calculating water salinity from the SP in these deep hot wells (standard deviation reduced from $69,000 \mathrm{ppm}$ to $21,000 \mathrm{ppm}$ ), and has identified several factors contributing to the remaining uncertainty. The most important of these are probably the variation in mud and mud filtrate properties as the well is drilled; and use of resistivity data rather than activity data for the mud and mud filtrate when calculating the water salinity. The main results of our work have been written up in a paper. "Problems and Partial Solutions in Using the S.P. Log to Predict Water Salinity in Deep Hot Wells". This paper will be presented at the 5 th Geopressured-Geothermal Energy Conference at L.S.U., Baton Rouge, LA, Oct. 13-15, 1981 ; and at the Geothermal Resources Council Meeting, Houston, Texas, Oct. $25-29,1981$.

Possibilities for Future Work: There is a possibility of some further improvement in accuracy of salinity predictions by use of regression analysis to include effect of variables not considered in the conventional calculation (this study is just now getting under way). A possible major improvement in accuracy could come from measurements and use of Nat ion activity, in addition to resistivity, of the mud and mud filtrate. The need for activity measurements would have to be demonstrated by measurements of muds and filtrates from a number of deep, hot wells, but the theoretical argument in favor of using activity data rather than resistivity data is strong. Additional data on variability of muds and mud filtrates in drilling wells is also needed. Finally, additional experimental data on variations of mud and filtrate resistivity and activity as a function of temperature are needed, to replace the data for $\mathrm{NaCl}$ solutions which is conventionally used in this work. Most mud filtrates from deep hot wells are much more complicated than simple $\mathrm{NaCl}$ solutions.

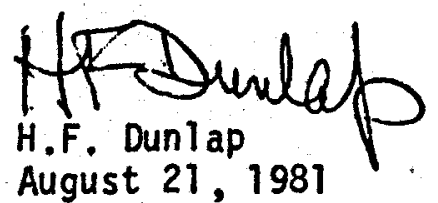




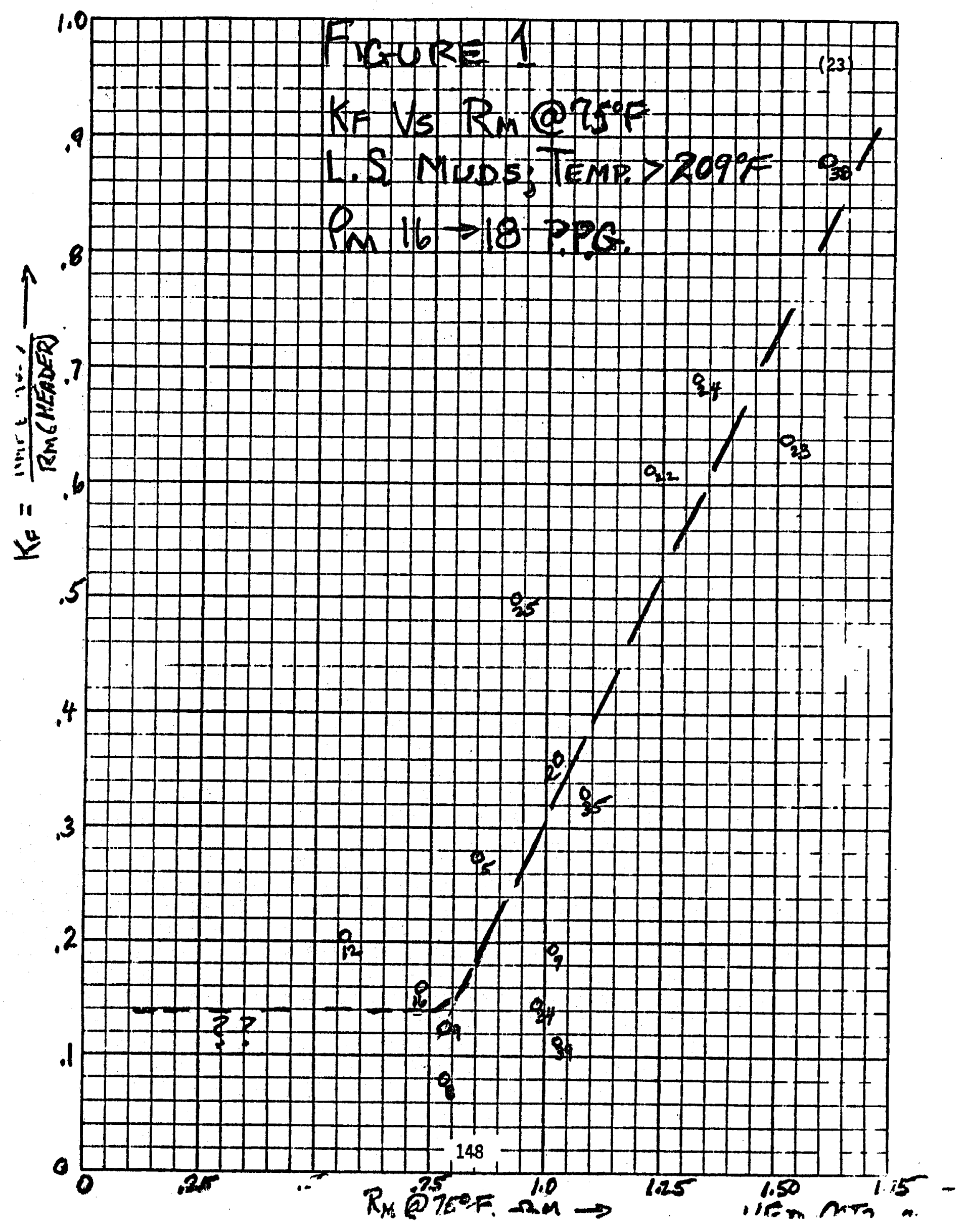


TABE (cont.)

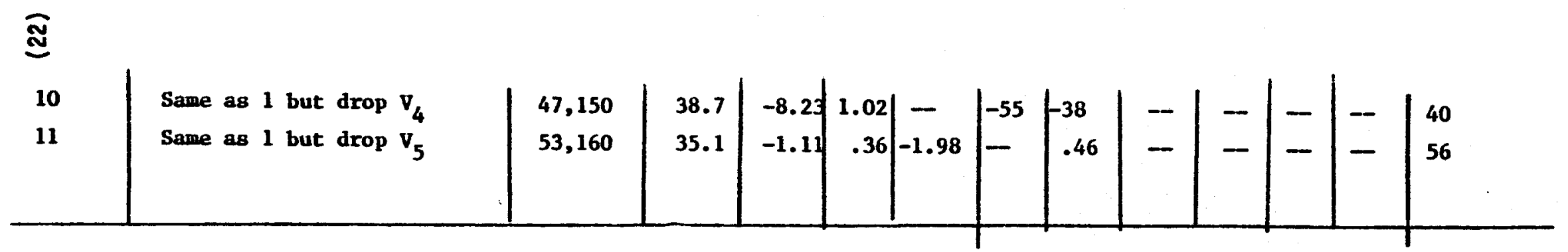


Serial Test True Sal. $\begin{array}{lcc}\# & \text { Test } & \text { True Sal. } \\ & \text { TSA }-1000\end{array}$

$\begin{array}{rrrr} & & & \\ 1 & & & 1 \\ 2 & 1 & 150 & .75 \\ 3 & 2 & 92 & .50 \\ 4 & 3 & 130 & .67 \\ 5 & 4 & 110 & .69 \\ 6 & 5 & 130 & .61 \\ 7 & 6 & 110 & .81 \\ 8 & 7 & 130 & .74 \\ 9 & 8 & 190 & .35 \\ 10 & 9 & 150 & .35 \\ 11 & 10 & 73 & .73 \\ 12 & 12 & 98 & .27 \\ 13 & 16 & 90 & .24 \\ 14 & 22 & 23 & .45 \\ 15 & 23 & 15 & .43 \\ 16 & 24 & 13 & .34 \\ 17 & 25 & 42 & .46 \\ 18 & 30 & 88 & .23 \\ 19 & 34 & 184 & .64 \\ 20 & 35 & 45 & .56 \\ 21 & 37 & 187 & .83 \\ 22 & 38 & 57 & 1.34 \\ 23 & 39 & 130 & .38 \\ 24 & 40 & 99 & .82 \\ 25 & 42 & 70 & .38 \\ 26 & 44 & 24 & .58 \\ & 45 & 57 & .68\end{array}$

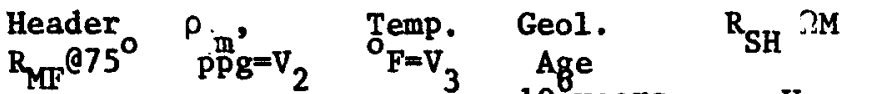
$\Omega \mathrm{M}$
$=\mathrm{V}_{1}$

$=\mathrm{v}_{4}$

$=v_{5} \quad$ Salo, $_{0} 1000$ $\mathrm{ppm}=\mathrm{v}_{6}$ $=\mathrm{v}_{4}$
Sal. 1

Sal. 2 00 ppm

$=\mathrm{v}_{8}$

Sa1.3

$\begin{array}{lll}14.3 & 270 & 25 \\ 17.5 & 256 & 29 \\ 12.2 & 196 & 35 \\ 13.3 & 204 & 35 \\ 16.1 & 260 & 35 \\ 15.9 & 288 & 35 \\ 16.8 & 248 & 29 \\ 17.6 & 266 & 37 \\ 17.6 & 266 & 37 \\ 15.6 & 219 & 32 \\ 17.9 & 304 & 35 \\ 17.3 & 332 & 37 \\ 17.3 & 238 & 25 \\ 16.0 & 209 & 40 \\ 16.1 & 250 & 52 \\ 16.2 & 264 & 32 \\ 11.4 & 201 & 32 \\ 17.5 & 254 & 35 \\ 17.0 & 209 & 35 \\ 15.7 & 221 & 35 \\ 16.5 & 213 & 35 \\ 16.1 & 230 & 35 \\ 16.0 & 185 & 35 \\ 14.3 & 194 & 35 \\ 14.6 & 243 & 52 \\ 14.4 & 238 & 52\end{array}$

$\begin{array}{cc}.85 & 68 \\ .63 & 72 \\ .60 & 54 \\ .60 & 51 \\ 1.2 & 50 \\ 2.0 & 38 \\ .91 & 48 \\ .73 & 48 \\ 1.35 & 48 \\ 1.10 & 49 \\ 1.67 & 49 \\ 2.0 & 52 \\ .55 & 42 \\ 1.67 & 21 \\ 2.0 & 42 \\ .80 & 43 \\ .77 & 85 \\ .77 & 52 \\ .84 & 25 \\ .69 & 32 \\ .79 & 62 \\ .65 & 41 \\ .70 & 31 \\ .56 & 63 \\ 3.33 & 22 \\ 1.67 & 23\end{array}$

$\begin{array}{rr}180 & 173 \\ 125 & 100 \\ 150 & 132 \\ 145 & 130 \\ 85 & 120 \\ 80 & 105 \\ 140 & 120 \\ 95 & 160 \\ 100 & 180 \\ 110 & 80 \\ 125 & 98 \\ 74 & 85 \\ 82 & 41 \\ 65 & 15 \\ 51 & 10 \\ 115 & 80 \\ 90 & 52 \\ 160 & 148 \\ 78 & 35 \\ 160 & 147 \\ 200 & 200 \\ 90 & 140 \\ 102 & 66 \\ 98 & 62 \\ 25 & 2 \\ 45 & 5\end{array}$

$\begin{array}{rr}192 & 80 \\ 91 & 60 \\ 140 & 60 \\ 130 & 60 \\ 123 & 60 \\ 105 & 60 \\ 123 & 60 \\ 180 & 90 \\ 202 & 90 \\ 73 & 60 \\ 98 & 30 \\ 72 & 20 \\ 18 & 35 \\ 22 & 10 \\ 2 & 25 \\ 75 & 40 \\ 38 & 35 \\ 160 & 58 \\ 15 & 26 \\ 160 & 50 \\ 225 & 90 \\ 150 & 30 \\ 55 & 45 \\ 50 & 40 \\ 1 & 24 \\ 2 & 32\end{array}$


PROGRESS REPORT \#20, 0ct. 1981

\section{STUDY OF LOG DERIVED MATER RESISITIVITY DATA}

\section{IN GEO ${ }^{2}$ FORMATIONS}

Summary: Our paper, "Problems \& Partial Solutlons in using the S.P. Log to Predict Water Salinity in Deep Hot Wells" was presented at the Geothermal Resources Counc1l meeting at Houston, and also at the Fifth Conference on Geopressured - Geothermal Energy at Baton Rouge.

The problem of the "anomalous" points on the $K_{F} v 8$ and wt. plot (See F1gure 1, 19th Progress Report) has been studled further. These polnts are all for welle with rather high mud resistivities. Figure 1 of this month's report shows a plot of points with nearly constant mud wt. (16-18 PPG) ve mud

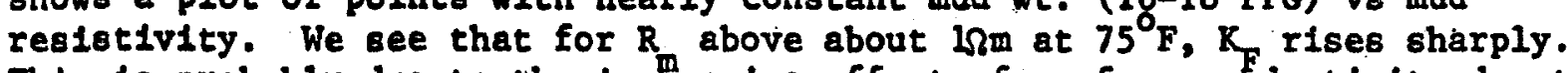
This 18 probably due to the Incteasing effect of surface conductivity due to the clay and other dispersed solids relative to the lonic conductivity of the dissolved salts in the relatively fresh mud filtrates.

Regression analyses have been run on the enlarged 26 case data set. Standard deviations are not greatly different from those reported earlier for the 16 case data set provided test \#38 (the most anomalous of the anomalous points) 18 dropped from the data. If test 38 is included, the standard deviation rises from $20,000 \mathrm{ppm}$ for the 16 case data set to 35,000 ppm for the 26 case data set. (See Table 1, 19th Progress Report, and Table 2, th1s Progress Report).

Th1s w111 be the last progress report on th1s problem under the present arrangement. For November and following months, the work will be done by a graduate otudent, Including consultation twice a month with the author. This arrangement 1s forced on us due to the present social security and Income tax laws.

Discussion: Our paper covering results of our research through last May was presented at two technical society meetings in October - once at Baton Rouge, La., the other at Houston, Texas.

The "anomalous" points discussed in last month's report (\$10, 22, 23, 24, 25, 38) have been stuldied further. All of these have rather high mud resietivities. If we minimize the effect of mud wt. by considering only a narrow range of mud welght values $(16+18 \mathrm{ppg}$.$) , we see from Figure 1$ that a plot of $K_{F}$ ve $B_{M}$ at $75^{\circ}$, w111 include all except test 10 (mud wt. $=15.6 \mathrm{ppg}$ ). The remaining 5 "enomelous" pointe define a rieing trend of $k_{F}$ values for $R_{M}>$ $\approx 1 \Omega M$ at $75^{\circ} \mathrm{F}$. Recall also that for the Grimes County well discussed in Progress Report 118 , August $181, K_{F}=R_{M F} / R_{M}$ was about 1.5 , for an $R_{m}$ value at $75^{\circ} F$ of 22.250M. Although the mud welghts are different, about 9 p.p.g. for the Grimes Co. well vs $16.5 \mathrm{ppg}$ for the wells in F1g. 1, this does seem to support a trend of rising $K$ with rieing $R_{M}$. 
It appears that a proper correlation of $\mathrm{K}_{\mathrm{F}}$ with mud weight must also include mud resistivity, at least in those cases where $R_{\text {is }}$ iarge. I suspect that a family of $K_{F} v s$ mud weight curves, one for each value of $R_{\text {, would best }}$ represent the situation. We would need much more data than we now have to define this family of curves.

A sertes of regression panalyees, simflar to those reported in the last two months progress reports, have been run on the enlarged, 26 case data set. Table 1 gives the data for the variables used in the regressions, and Table 2 gives the standard deviatlons between known salinity and salinity estimated from the regression, plus constants in the estimation equation, for each of the regressions. Comparison of this data with the results shown on Table 1 of the 19 th Progress Report and Table 2 of the 18th Progress Report Indicate that if Test 3818 omitted (the most "anomalous" of the anomalous points in the data set) results are not greatly different for the 26 case data set as compared to the 16 case data set $(20,000 \mathrm{ppm}$ std dev. for the 16 case set, rising to $23,000 \mathrm{ppm}$ for the 26 case data set). If case 38 is included the standard deviation Increases to 35,000 ppm for the 26 case data set. Apparently standard devistions in the 1ow 20,000 range reflect about the best that can be done using this data. This is quite a reasonable result when we remember the unresolved problem of short term fluctuations in $R_{M}$ and $R_{M F}$ when the well is being drilled. 


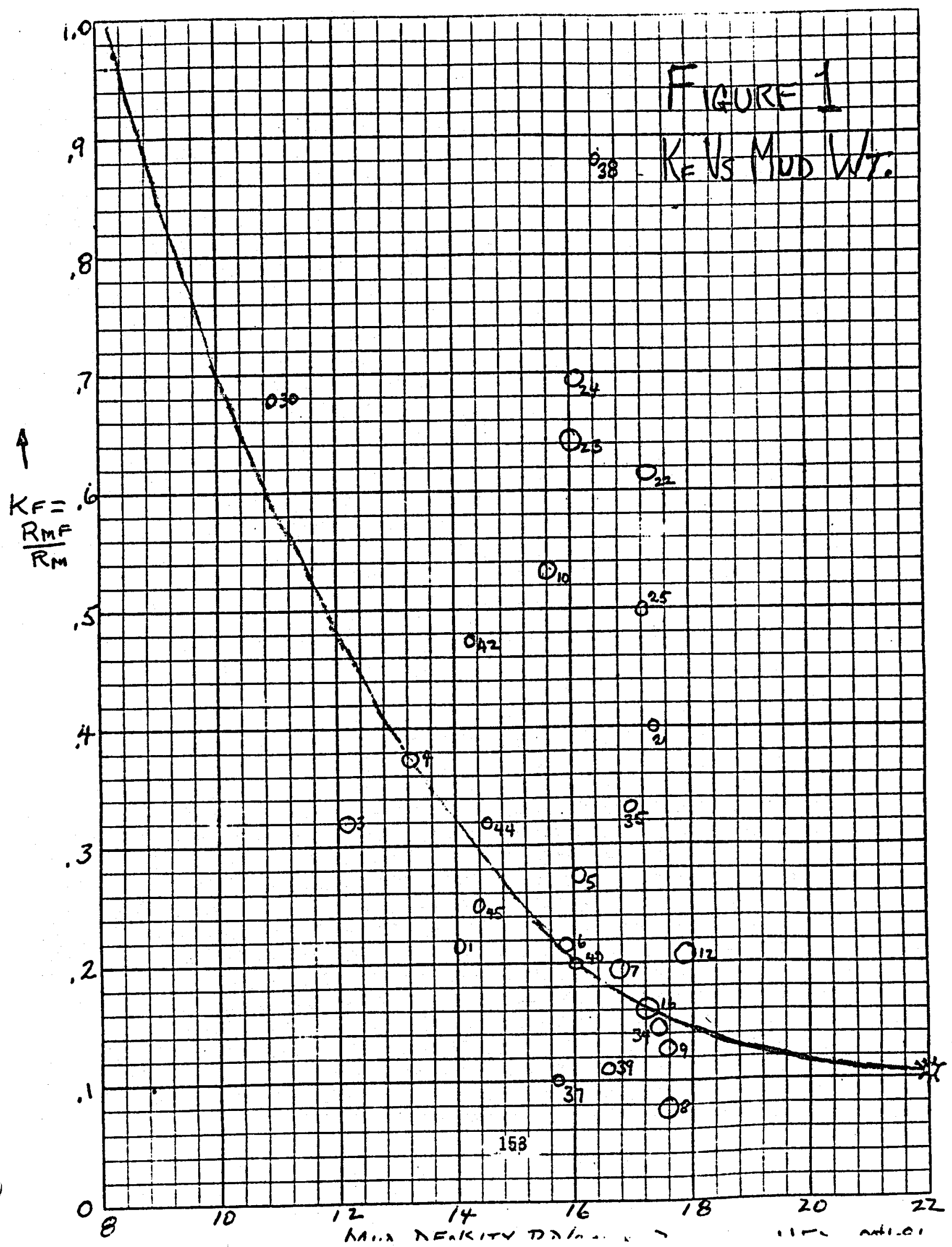


TABLE 1

Corrected Standard Deviations for Regression Analyses

Lignosulfonate Muds

\begin{tabular}{l} 
Kegression \# Variables in Regression $\begin{array}{r}\text { Corrected Std. } \\
\text { dev. } 1000 \mathrm{ppm}\end{array}$ \\
\hline
\end{tabular}

Conv. Sal. Calc. from

SP $\log =\mathrm{v}_{6}$

(1) $v_{6}$ plus all var. in eq.

(1) except $v_{7} \& v_{9}$

(2) Same as (1) except replace

$$
v_{6} \text { by } v_{9}
$$

(3)

Same as (1) except drop

$$
v_{6}
$$

$-\cdots-$

Salinity 3 calculation $=v_{7}$

(4)

Same as ( 1 ) except replace

$$
v_{6} \text { by } v_{7} \text { (Sal.3) }
$$

(5) Same as (4) except drop $\mathrm{v}_{2}=\rho \mathrm{m}$

(6)

Same as (4) except drop

$$
\mathrm{v}_{1}=\mathrm{R}_{\mathrm{mF}}
$$

(7) Same as (4) except drop $\mathrm{V}_{5}=\mathrm{R}_{\mathrm{SH}}$

(8) Same as $(4)$ except drop
$V_{3}=T{ }_{F}$

(9)

Same as (4) except drop $\mathrm{v}_{4}=$ Age

(10)
69.0

49.7

49.7

47.4

21.0

19.6

19.0

19.2

19.3

19.6

19.8

20.0
Non Lignosulfonate Muds

Variables in Regression

Corrected std. dev. 1000 ppm

Same as L.S. case

31.6

Same as L.S. case

19.2

Same as L.S. case

19.6

Same as L.S. case

21.7

$K_{F}$ Sal. = Sal. 1 calculation $=v_{7}$

19.6

Same as (1), except replace

$v_{6}$ by $v_{7}$ (sal. 1$)$

8.8

Same as L.S. case

8.5

Same as L.S. case

8.5

Same as L.S. case

9.8

Same as I.S. case

8.3

Same as L.S. case

8.5 
TABLE 2 Lignosulfonate Muds - Texas

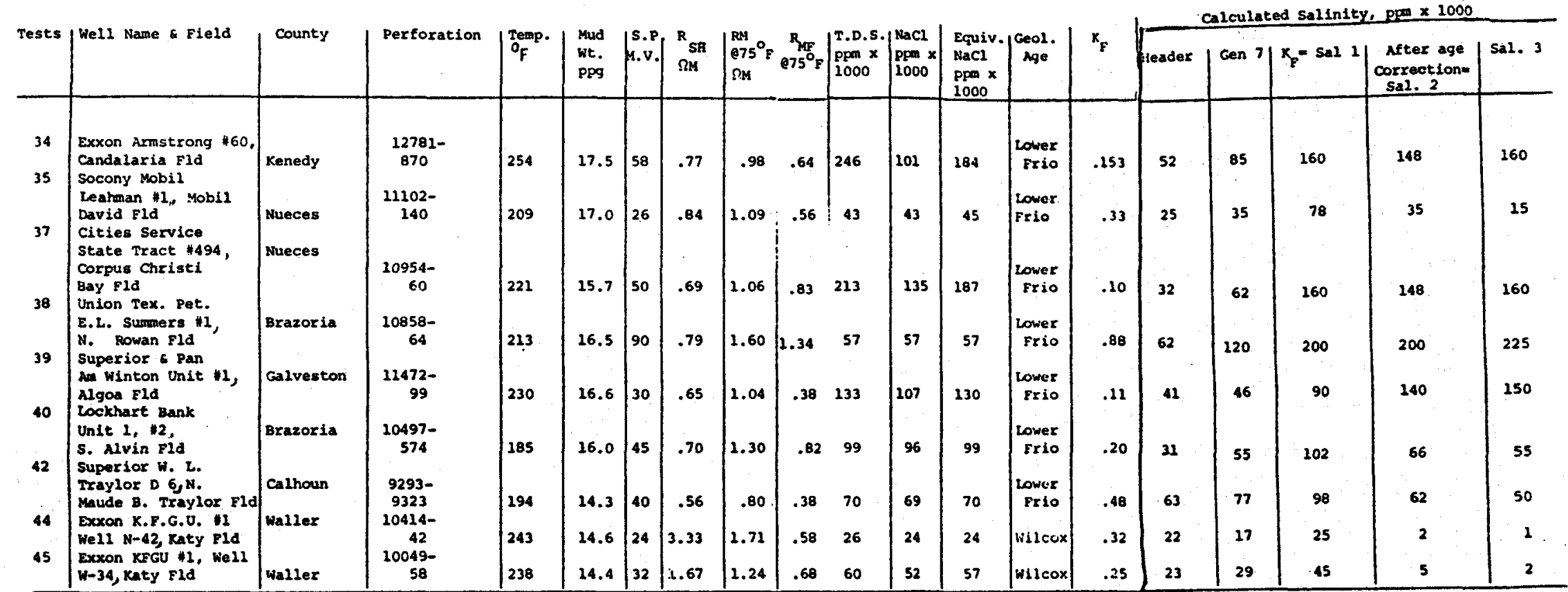

- "Equivalent Nacl" is obtained from chemical analysis of formation water using

Schlumberger chast $\operatorname{cen} 8$. 
TABLE 3

Standard Deviations - Lignosulfonate Muds (26 Cases)

Method of Calculating Water Salinity from S.P. Standard Deviations $1000 \mathrm{ppm}$

Conventional, using log header values of $R_{M F} \quad 71.2$

Ditto, Except exclude test $38 \quad 72.6$

Conventional, using Gen 7 values of $R_{M F} \quad 63.9$

Ditto, except exclude test $38 \quad 63.9$

Salinity 1 calculation as outlined in our paper $\quad 49.3$

Ditto, except exclude test $38 \quad 41.0$

Salinity 2 calculation (after age correction) 37.2

Ditto, except exclude test $38 \quad 24.3$

$\begin{array}{ll}\text { Salinity } 3 \text { calculation } & 42.5\end{array}$

Ditto, except exclude test $38 \quad 26.5$ 
TABLE 4

Data for Anomalous Cases on $\mathrm{K}_{\mathrm{F}}$ Curve, Lignosulfonate Mud

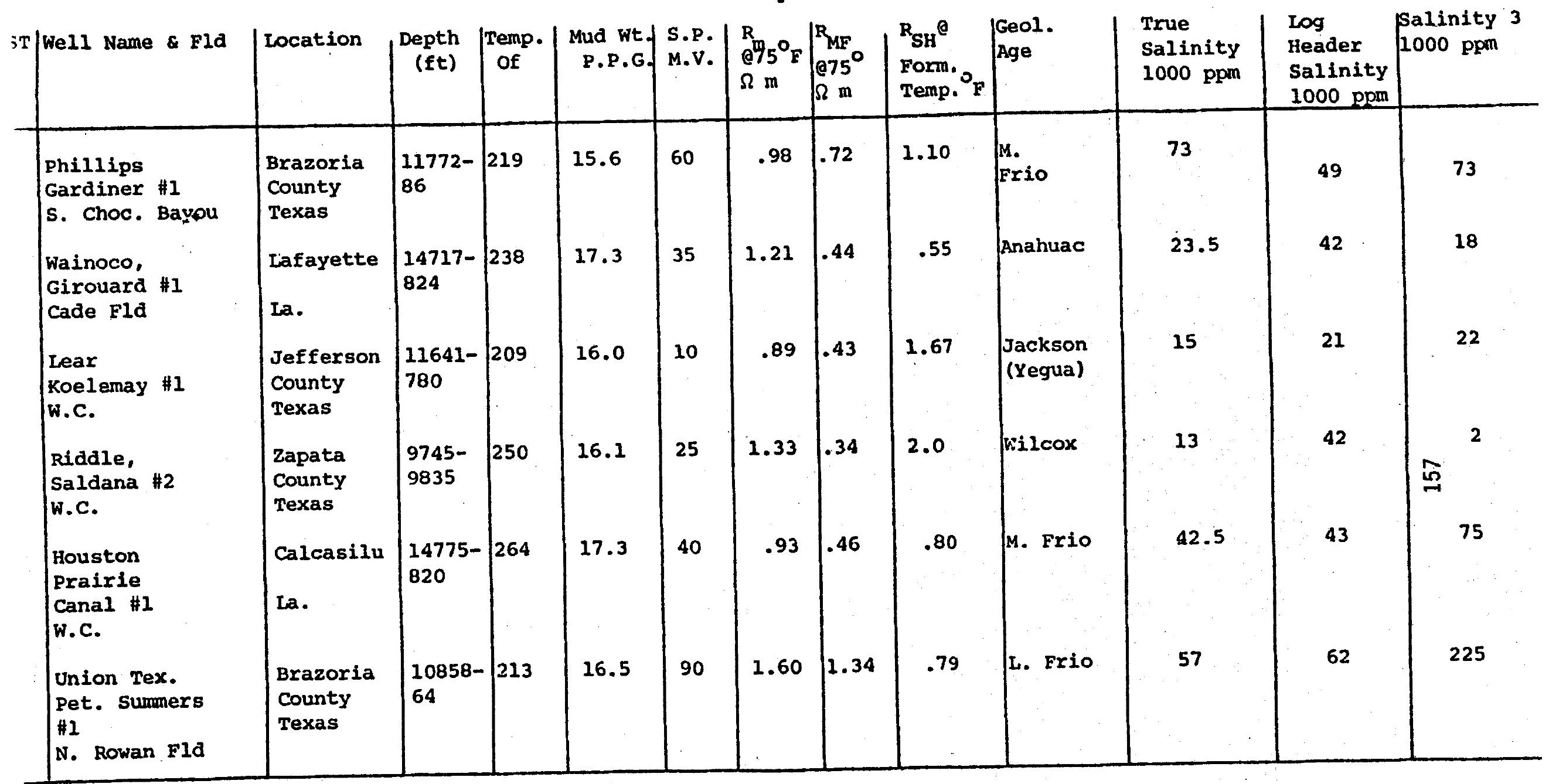


Progress Report \#19

September 1981

Study of Log Derived Water Resistivity Datà

in $\mathrm{GeO}^{2}$ Formations

Summary: We made an error last month in calculating the standard deviation of salinitiesusing regression analysis. We used the formula sţandard deviation $\sigma=\sqrt{\frac{\Sigma \Delta^{2}}{n-1}}$, where $n$ is the number of data points, and $\Sigma \Delta^{2}$ is the sum of squares of deviations between true and calculated salinity. This is correct for cases where regression analysis is not used, but for the regression analysis cases, we should have used the formula

$$
\sigma=\sqrt{\frac{\Sigma \Delta^{2}}{n-k}}
$$

where $\mathrm{k}$ is the number of constants determined in the regression analysis. Corrected figures for the standard deviations are shown in Table 1. These should replace the data given in Tables 1 and 3 in last month's progress report. For lignosulfonate muds, the regression analysis (based on the corrected standard deviation figures) does not significantly improve the calculated salinities over the results obtained in our paper. For non lignosulfonate muds, there seems to be a significant improvement by use of regression analysis.

We have obtained 9 additional tests (all in Texas) using dense lignosulfonate muds from the Bureau of Economic Geology (See Table 2). These, plus test 30 (see Table 1, Progress Report \#17), and the 16 cases reported in our paper, give a total data set of 26 cases for SP calculations in wells with dense, hot, lignosulfonate muds. Table 3 shows standard deviations for various methods of calculating water salinity from the SP for this enlarged data set. Results check those reported in our paper, for the 16 case data set fairly well for the standard calculation method using $\log$ header RMF data. The standard deviation for the conventional salinity calculation is still about $70,000 \mathrm{ppm}$. The standard deviation for salinity 2 or salinity 3 is increased to about 40,000 ppm (as compared to $21,000 \mathrm{ppm}$ for the 16 case data set reported in our paper). Note, however, that if test \#38 is eliminated from the data set, the standard deviation for the convential calculation is essentially unchanged, while the standard deviation for salinity 2 or salinity 3 drops to about 25,000ppm, very close to the $21,000 \mathrm{ppm}$ reported earlier.

We have no specific reason to reject test 38 , but it does seem to be unusual. Figure 1 shows a plot of $K_{E}=\frac{R M F}{R M}$ vs. mud wt. All the new data except for test 38 falls fairly close to the dashed line, reproduced from from Figure 1 of Progress Report \#6. Test 38 shows the greatest deviation from the dashed 1ine. Data for the 6 anomalous cases $(5 \mathrm{from}$ the old data set plus test 38 ) are shown in Table 4 . There are not any obvious similarities in data for these anomalous cases. 
We plan to apply regression analysis to the enlarged data set and will report this next month.

\section{Discussion:}

An error was made in calculating the standard deviations for regression analysis studies in last month's progress report. We used an incorrect number of degrees of freedom in calculating the standard deviation. In general, the degrees of freedom must be reduced by 1 for each constant fitted by the regression analysis (counting both the coefficients of the variables in the regression equation and the constant term in this equation). As we were fitting from 5 to 7 constants in the regression analysis and we only had 16 cases in our data set, this made a significant difference in the standard deviation equation, changing it from $\sigma=\sqrt{\frac{\Sigma \Delta^{2}}{15}}$ (incorrectly used last month) to $\sigma=\sqrt{\frac{\Sigma \Delta^{2}}{9+11}}$ which is what should be used for the regression cases. The correct standard deviations are given in Table 1 . We see that for the lignosulfonate muds, use of regression analysis does little to reduce the standard deviation of calculated salinity below the 21,000 ppr value reported previously. For the non lignosulfonate muds, regression analysis lowers the standard deviation from about $20,000 \mathrm{ppm}$ (using the $K_{F}$ or salinity 1 calculation) to about $9,000 \mathrm{ppm}$.

We have reviewed a large number of additional Texas water samples obtained by the Bureau of Economic Geology (described by them in the September 10 Geothermal Board of Advisors Report from M.H. Dorfman). Many of these were from low temperature, low mud weight wells, but 9 additional lignosulfonate cases which appear to have acceptable gas/water ratios, high mud weight, and high temperature were obtained. Criteria for acceptance were: Gas/water ratio < $100 \mathrm{MCF} / \mathrm{Bbl}$., Temperature > $185^{\circ} \mathrm{F}$; mud weight > 14.3ppg/ The average temperature was $221^{\circ} \mathrm{F}$ and average mud weight was $15.8 \mathrm{ppg}$. The range of true salinities was from 24,000 to $287,000 \mathrm{ppm}$, averaging 95,000 ppm. No measurements of $R$ were available, but complete chemical analysis had been run, from which "equivalent" $\mathrm{NaCl}$ salinities could be calculated using the Schlumberger charts shown on Gen 8 of their chart manual.

It is interesting that in some cases the Ca content was quite high (apparently present as $\mathrm{CaCl}_{2}$ ). In test \#34, the Ca/Na ratio was $32 / 40$; in test \#37 it was $21 / 54$; and in test \#39, it was $9 / 42$. In spite of those large deviations from a simple $\mathrm{NaCl}$ formation water, the calculated salinity 2 or salinity 3 checks the true "equivalent" salinity reasonably well-much closer than the conventionally calculated log header salinity does.

Note that 7 of the 9 new cases are the Lower Frio. This is unfortunate, since it was the dividing line in our earlier study, with wells in this age level being assigned to either the "younger" or "older". age group when calculating salinity 2. In three cases, \#34, 37, and 38 I assigned the test to the "younger" correlation, since the "older" correlation would have implied super saturation of formation water. In the other 
four cases, the assignment was made to get the best check to the equivalent water salinity calculated using Gen 8 . This turned out to be the "younger" correlation for all except case 39, where the "older" correlation was used.

A calculation of standard deviations using various methods of calculating the water salinity was made for the entire 26 case data set (16 cases reported in our paper, plus test 30, reported in Progress Report \#17, Table 1, plus the 9 new cases listed in Table 2). Results are shown in Table 3. The result is not greatly different from that obtained using the 16 case data set (reported in our paper) when using the log header derived $R$ value and the conventional calculation method, about $70,000 \mathrm{ppm}$ for either data set. The standard deviation for salinity 1 (obtained using $R_{M F}$ values from the dashed curve of Figure 1) drops to about $50,000 \mathrm{ppm}$. If we make the age correction (Salinity 2) the value drops further to $37,000 \mathrm{ppm}$. Applying the final correction (Salinity 3) actually raises the value a little to $43,000 \mathrm{ppm}$. These values for salinity 2 and 3 are about twice as great as the $21,000 \mathrm{ppm}$ value for the 16 case data set reported earlier. However we should note that if we drop case 38 , the standard deviations are unchanged for the conventional calculation but drop to $41,000 \mathrm{ppm}$ for salinity 1, 24,000 for salinity 2 and 27,000 for salinity 3. These last two values are not too different from the $21,000 \mathrm{ppm}$ value reported earlier.

We have no specific reason for rejecting test 38 , but it does appear unusual. Figure 1 shows a plot of $K_{F}=\frac{R_{m F}}{R_{m}}$ vs mud weight taken from $\frac{R_{m}}{R_{m}}$

Figure 1, Progress report \#6, together with the $k_{F}$ values for all 26 cases in our enlarged data set. There are six points which seem to deviate considerably from the general trend of the data \#10,22, 23, 24, 25, and 38 . of these, test 38 deviates the most. Table 4 shows data for these six anomalous points. We have not been able to deduce any particular differences between these and the remaining cases in our data set.

We hope to carry out regression analysis for the enlarged data set and will report these next month.

H.F. Dunlap, Oct. 9, 1981

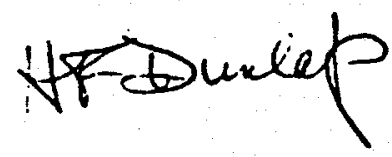


57. Goldstein. J.L. Brunschede. G. Y. \& Browa, M. S. J. biol. Oh.m. 250, 7854-7862 (1975), 58. Van Leuvis, F., Cassiman, J.J. \& Van Den Bergte, H. Expl Cell Res 117, 273-28? (1978). 39. Gliemann. J. \& Sonne, O. J. Sió. Chem. 253, 7857-7863 (1978).

60. Kaitis. S. O. Morgan, E. H. Br. J. Haemat. 28, 37-52 (1974).

61. Hemmajplardin, D. Morkan, E. H. Biochim iwophy. Acto \$26, 385-398 (1975)

52. Eiadshaw, R. A. A. Rez. Biochem. 47, 191-216 (1978).

63. Bergeron, J. J. M. Sikstrom, R., Hand, A. R. \& Posner, B. L. J. Call Biol 60, 427-443 (197)).

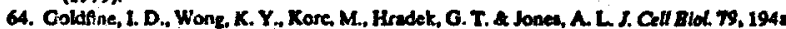
(1978).

65. Neuteld, E. F., Sando, G. N., Garvin, A. J. \& Rome, L. H. J. supramolec. Struct 4, 95-101 (1977).
66. Sly, W. S. \& Stahl, P. in Thensport of Macromolecules in Celludar 5ysuems (ed. Siverrtein, 8. C.) 229-244 (Dablem Xonferenzen, Bertia, 1978).

67. Rome, L. H. Garvin. A. J.. Alietta, M. M. \& Neufeld, E. F. C.ll (to the preai).

68. Newmark, P., Newman. G. E. \& O'Brien, J. R. P. Anchs Biochern. Biophy. 16:, 121-1 30 (1970).

69. Pletsch, Q. A. \& Coffey, J. W. J. biol. Chem. 246, $4619-4629$ (1971).

70. Conn, P. M., Conti, M., Harwood, J. P., DA\{au, M. L \& Cat1, K. J. Nanure 27.4, $598-600$ (1973)

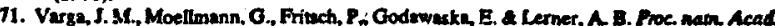
SEi. U.S.A. 73, 559-562 (1975).

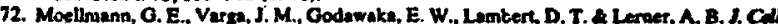
Biol. 79, 196a (1978).

\title{
Non-exponential decay in dielectrics and dynamics of correlated systems
}

\author{
L. A. Dissado \& R. M. Hiil \\ Chelsea College, University of London, Pulton Place, London SW6, UK
}

A new model for the relaxation of a potential perturbation in dielectric materials is developed based on the correlated properties of a two-level system containing two types of decay mechanism. The time and frequency behaviour of the general relaxation process is shown to be in accord with recent experimental analyses. The technique developed to analyse the model is of general applicability in the solid, and liquid, state.

Ir has been shown ${ }^{1}$ previously that for materials exhibiting a dielectric loss peak the magnitude of the imaginary part of the susceptibility, as a function of frequency, obeys the empirical relationship.

$$
\chi^{\prime \prime}(\omega)=\frac{\omega^{m}}{\left(\omega_{p}^{2 \pi}+\omega^{2 n}\right)^{(1-n+m) / 2 i}}
$$

where $0 \leqslant m, n$ and $s \leqslant 1$. In the post-peak region, $\omega>\omega_{p}$, this relationship can be written in the torm $\chi_{(\omega)} \propto(i \omega)^{-(1-n)}$ and Jonscher ${ }^{2-5}$ has suggested that the behaviour can best be understood as

$$
X^{\prime \prime}(0) / X_{(\infty)}^{\prime}=\cot (n \pi / 2)=\text { constant }
$$

which states that the ratio of the energy lost to the energy stored is a constant. In the pre-peak region the imaginary part of the susceptibility exhibits a power law dependence, $\omega^{m}$, and equatiun (2) is not obeyed. The empirical equation (1) describes a complete decay characteristic for the materials exhibiting loss peaks. It can be Krumers-Kronig transformed to give $x^{\prime}(\omega)$, and agreement with experimental measurements has been observed. We use here the presence of a loss peak to define our term dipolar dielectric, and we shall only consider this class of materials.

The universal equation (2) requires the susceptibility to follow a power law in time $\left(l^{-n}\right)$ in the equivalent, short time, regign $\mathrm{tt}$ has recent'y been postulated by Ngai et al. ${ }^{6}$ that the origtr 26 form of decay lies in an infrared divergence mechanism and that the basic requirements for the application of this mechanism in a wide range of systems have been established computationaliy.

Starting from the concept of an assembly in which the local units possess two equilibrium positions ${ }^{7.8}$ (a two-level syst=m) we will show that the consequence of interaction betwsen the local units leads to a complete description of the susceptibility of dipolar dielectrics. The post-peak behaviour arises naturaliy from this description. The method used is powerful and yields detailed and quantitative information on the microscopic structure and its dynamics. As the final expressions describe the macroscopic behaviour they can be conceived in a variety of ways and reveal the flexibility of the approach presented hers. The results of this analysis have a wide range of applicability outside purely dieiectric behaviour and similar approaches should be generally applicable.

\section{The $t^{-n}$ behaviour}

Before describing dielectric relaxation in terms of the cooperative model we must describe briefiy the origins and requirements of the $t^{-n}$ behaviour, which is a special case of the time development of transients ${ }^{9}$. Consider a system divided into two interacting sub-systems. The first of these responds rapidly to a stimulus generating a change in the interaction which, in turn, causes a much slower response of the second sub-system. The state of the total system then corresponds to the excited first system together with the unresponded second system, and can be considered as a transient or metastable state which slowly decays as the second system responds. In this way a FranckCondon progression is developed in molecular spectra ${ }^{10-12}$, the fast system being a high frequency transition which is coupled to the slow response of a discrete spectrum of low frequency oscillations.

The special requirements for $a i^{-n}$ behaviour are ${ }^{23}$ : (1) a continuous spectrum of slow responders extending to zero frequency: (2) a constant density of transition states, per unit energy, for the slow system, in the same energy range; (3) an effective population distribution in the slow states such that they can be regarded as either fully occupied or unoccupied oniy. 
The time behaviour of the state vector of the transient can be obtained from the total hamiltonian $H$ as

$$
\exp (-\mathrm{i} H t)=\langle r \mid 0\rangle
$$

which in second order perturbation theory ${ }^{10,14}$, in energy/frequency normalised units, becomes

$$
\exp (-\mathrm{i} E t) \cdot \exp \{-F(t)\}
$$

with $E$ the unspecified excitation energy of the transient, and

$$
F(t)=\mathrm{in} \zeta t-\int_{0}^{\zeta} \frac{|V N|^{2}}{u}\{1-\exp (-\mathrm{i} u t)\} \mathrm{d} u
$$

$N$ is the total number of slow responders and $\zeta$ is their maximum excitation energy, the constant density of states is thus $N / \zeta . V$ is the interaction change brought about by the fast excitation and $u$ the energy difference for nett excitations within the slow response system. Equation (5) is obtained by allowing $V$ to cause excitations and de-excitations in the slow system, the double sum over initial and final states being replaced by the already conipleted sum over initial states, for a given energy difference $u$, and an integration over $u$. This is shown in Fig. 1 .

The average energy change per fast excitation will be distributed over the $N$ slow responders and is $N V$. As $\zeta$ is the maximum excitation energy, $|N V|^{2} /(\zeta)^{2}$ is less than unity and is set equal to $n$. Integrating equation (5) ${ }^{13.15 .16}$ gives

$$
F(t)=i n \zeta t-n\left\{\gamma+\ln (\mathrm{i} \zeta t)+E_{1}(\mathrm{i} \zeta t)\right\}
$$

where $\gamma$ is Euler's constant and $E_{1}(i z)$ an exponential integral ${ }^{17}$. For short times, such that $t \zeta<1$

$$
F(t) \rightarrow 0
$$

and the transient oscillates with its excitation frequency corresponding to the energy $E$. At long times $\left(t_{\zeta}>1\right)$

$$
F(t)=\exp \{-\mathrm{i}(E-n \zeta) t\} \cdot \exp (-n \gamma) \cdot \exp (\mathrm{in} \pi / 2) \cdot(t \zeta)^{-n}
$$

where the excitation energy of the transient has been reduced by $n \zeta$, and the transient decays as $t^{-n}$.

In applying this result to our problem the fast excitations and the slow responders are assumed to lie in the same continuum of states, the slow responders merely being slower than a particular fast transient excitation within the same total system. The system returns to its unexcited state by means of excitations of the slow responders, which decay monotorically. For this reason $E$ is taken equal to $n \xi$, and it has already been shown that $n$ lies between zero and unity corresponding to no excitation or total excitation of the system respectively. Note that any observable property of the transient follows a behaviour governed by the real part of equation (4), and thus oscillates with diminishing irequency while decaying as $t^{-n}$.

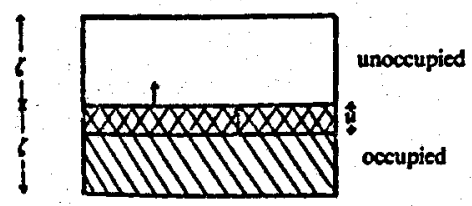

ny. 1 . The iwo-level system: the range of initial states available for encitution with energy $u$ is shown by cross hatching. The equw-isni number of initial states is $(N u / \zeta)$ where $N / \zeta$ is the constant energy density.

\section{Interacting two-level systems}

A khiil two-level system can be considered as a group of atoms, hins or molecules possessing two equilibrium configurations 16 icparated by a small chergy difference and between which locai tunnelling is allowed ${ }^{7,8}$. Such a system can be described by a spin formalism in which the encrgy tensor is

$$
\left(\begin{array}{cc}
B_{e} & U_{e} \\
U_{e} & -B_{e}
\end{array}\right)
$$

where $B_{e}$ is half the energy difference between local potential minima and $U_{r}$ is the off-diagonal tunnelling (transition) element. Such systems can couple to elastic deformations and have been used to describe a range of glass properties ${ }^{18}$. When the local system possesses a dipole moment the coupling to an electric field takes the form

$$
\left(\begin{array}{rr}
d & \mu \\
\mu & -d
\end{array}\right) F
$$

with the off-diagonal elements $\mu$ allowing a resonance absorption, the diagonal elements a relaxation spectra. A spin-spin interaction arises from the coupling of pairs of local spin systems through the off-diagonal elements of the tensor in equation (9). These interact with phonons and give the usual dipolar spin-spin interaction through a virtual two-phonon exchange mechanism ${ }^{19}$. The spin-spin interaction can be regarded as a perturbation on an unperturbed local system with energy leveis $\pm B$ e together with a local transition interaction. It contains three types of term, each of which has a definite and unique influence on the overall system.

(1) The secular interaction: this is a dipole-dipole cooperative interaction which contributes to the energy of each unperturbed spin. It is the hasis of the Ising hamiltonian and when calculated in the mean field approximation has a contribution to $B$ of $T_{\mathrm{c}} M$, where $M$ is the mean value of the $z$ component of the local dipole unit vector, in this case electric, and $T_{\varepsilon}$ is a characteristic parameter of the system. The system can no longer be regarded as a set of local systems because of the cooperative inferaction. Its energy levels are macroscopic and the macroscopic thermal average, $M_{e}$, of $M$ is

$$
M_{*}=\tanh \left(\frac{B+k T_{0} M_{*}}{k T}\right)
$$

which is a consequence of the condition that the dipoles can only be in one of two states. $B$ is the average of $B$, over all the system, and the dipole of the system in equilibrium is $N M_{0} d$. The value of $M_{0}$ is defined by equation (11) and is determined from $B, T_{c}$ and the temperature $T$. The energy $B$ can be regarded as the splitting of a two-level system by a well-defined internal field. In amorphous glassy systems the local value of $B_{l}$ is not constant but takes a continuous range of values with a constant number density at each value ${ }^{19.20}$. It has been suggested ${ }^{6}$ that this applies to a wide variety of materials.

(2) The flip-flop interaction: this interaction allows a pair of dipoles to exchange spins synchronously and without altering $M$. Local spins move through the whole system by this mechanism. The time taken to complete a spin exchange is

$$
t_{0}=\pi / V_{a}
$$

where $V_{n}$ is the flip-fiop interaction energy. The time has been estimated as $10^{-8}-10^{-10}$ s (ref. 19).

On a time scale greater than $t_{e}$ the local spins will sample the whole of the local values of $B_{\text {e. In general those local spins whose }}$ values of $B_{\varepsilon}$ differ by less than the maximum value of the interaction energy, $V_{\mathrm{amax}}$ can be regarded as in resonance and hence involved in a true spin-spin exchange. Those spins with a greater difference than $V_{\max }$ interact in an off resonance manner and do not have a true spin-spin exchange.

In this way, on a time scale greater than $t_{e}$, the macroscopic value of $B$ in equation (11) will alter without altering $M_{\text {. }}$. But the nature of equation (11) requires an alteration in $B$ to generate a consequent change in $M_{e}$. Thus the fip-flop interaction has to be regarded as causing fluctuations in $M_{e}$ about a well defined average.

62 (3) The raising and lowering interaction: this interaction couples $M$ with raising and lowering operators. These operators allow excitation and de-excitation of the unperturbed local 
system, and generate absorptions at multiples of the Larmor frequency in nuclear magnetic resonance spectra ${ }^{21}$. When pairedi together the value of $M$ is unchanged and oscillations are genicrated at frequencies cqual to the difference between excited and unexcited local systems ${ }^{22}$. Since the frequencies span the range irom zero up to a particular maximum they can be regarded as a system of slow responders.

All spins will be connected by this interaction, hence a fuctuation such as a flip-flop interaction will create a transient which decays as $t^{-m}$ as the frequencies less than $V_{\mathrm{tmax}}$, that is, $10^{8}-10^{10} \mathrm{~Hz}$, respond. The magnitude of the parameter being given by

$$
m=\left(V_{\mathrm{a} \text { average }} / V_{\mathrm{amax}}\right)^{2}
$$

\section{The rate equation}

The fundamental concepts required to establish the framework of our approach have already been established. The basic model is that a deviation from equilibrium in a macroscopic system resulting from the application or removal of an external field is restored to an equilibrium that is itself fluctuating on a long time scale. Because of the connection between $M$ and $B$ in equation (11) fluctuations in the ground state energy $B$ must affect the rate of restoration of equilibrium. Calculations using this model are applicable to many fields but we shall consider here a dipolar dielectric.

The dipolar dielectric is represented by a double minimum in the total (macroscopic) free energy as indicated in Fig. 2. Each minimum refers to a set of configurations of local dipoles with their orientations effectively in one of two alternative directions. Each configuration is thus specified by a set of local dipole otientations, simultaneously fully occupied, which have an equal number of unoccupied levels belonging to a configuration with an opposing dipole orientation and separated from them by a large potential barrier. The two sets of configurations are therefore only accessible to each other either by thermally activated or tunnelling processes. Thermal equilibrium is established between groups of macroscopic configurations rather than independent local orientations.

After the removal of an externally applied perturbing influence there are two competing relaxation processes as well as the fluctuations to consider. These are thermal activation and local tunnelling, (Fig. $2 c$ and $b$ ).

The rate equation for the thermal process can be written $a^{23}$

$$
\frac{\mathrm{d} M}{\mathrm{~d} t}=-\nu_{\mathrm{E}} \cosh \left(\frac{B+k T_{\mathrm{c}} M}{k T}\right)\left\{M-\tanh \left(\frac{B+k T_{\mathrm{c}} M}{k T}\right)\right\}
$$

where $\nu_{E}$ has an activated form with a pre-exponential frequency of the order of $10^{13} \mathrm{~Hz}$, that is

$$
\nu_{E}=\nu_{0} \exp (-\Delta / k T)
$$

Writing

$$
M=M^{\prime}+\tanh \left(\frac{B+k T_{\mathrm{c}} M_{\mathrm{e}}}{k T}\right)=M^{\prime}+M_{\mathrm{e}}
$$

a linear form of equation (14), exact in $M_{0}$, can be found,

$$
\begin{aligned}
\frac{\mathrm{d} M^{\prime}}{\mathrm{d} t} & =-\nu_{\mathrm{E}} \cosh \left(\frac{B+k T_{c} M_{\mathrm{a}}}{k T}\right)\left[M^{\prime}\left\{1-\left(1-M_{*}^{2}\right) T_{\mathrm{c}} / T\right\}\right] \\
& =-\omega_{\mathrm{p}} M^{\prime}
\end{aligned}
$$

where $M^{\prime}$ is the deviation from equilibrium of $M$.

As $\omega_{p}$ involves $M_{c}$ it can be considered as an expectation value of an operator in the fluctuating system. Thus the rate itself fluctuates and must be averaged over these fluctuations in $\omega_{\mathrm{p}}$. To carry out this averaging, the form of the equilibrium fuctuations inust be determined.

Resonance flip-flops exchange dipoles between the two minima, in each of which a new configuration is generated. The initial equilibrium value of $B$ of the macroscopic state is 163 appropriate to the new configurations and the state evolves in

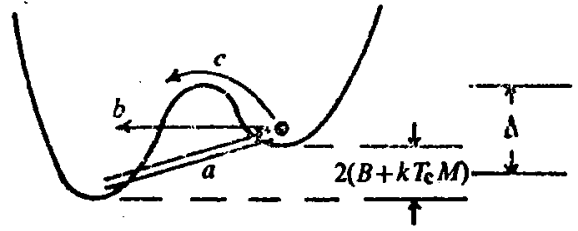

Fig. 2 A double minima potential. $a, A$ tunnelling process of synchronous excitation and de-excitation. $b, A$ cooperative tunnelling relaxation process. $c, A$ thermally activated relaxation process. $\Delta$, the average energy of the maximum above the two minima.

time to accommodate the change. The state of the configuration in each minimum immediately following a flip-flop will effectively be that due to the excitation of a dipole from a fully occupied to a non-ociupied level. The poptiation criterion (3) for the slow responders is completely fulfilled and the time evolution of each configuration, and hence the system, follows a time power law, the exponent of which has been defined as $m$.

During the transient decay the requirement of a well defined average necessitates a balance which arises from the multiplyconnected pairs between the two configurations of the transient, generating a new equilibrium state of the system that satisfies equation (11).

The fluctuations must therefore follow a time development of the form

$$
\left(t-t_{1}\right)^{m} \cdot t_{1}^{-m}
$$

as the balancing is delayed in time by $t_{1}$ to allow for the initial decay. Equation (18) represents fiuctuations about a well defined average expectation value because of the constant time average

$$
t^{-1} \int_{0}^{t}\left(t-t_{1}\right)^{m} \cdot t_{1}^{-m} \mathrm{~d} t_{1}=\Gamma(1+m) \cdot \Gamma(1-m)
$$

To allow for these fluctuations a time average has to be taken in the rate equation, equation (17),

$$
\left\langle\frac{\mathrm{d} M}{\mathrm{~d} t}\right\rangle \propto-\omega_{\mathrm{p}}(t)^{-1} \int_{0}^{1}\left(t-t_{1}\right)^{m} t_{1}^{-m} M^{\prime}\left(t-t_{1}\right) \mathrm{d} t_{1}
$$

The evolution of the initial state, $t_{1}^{-m}$, competes with the thermal decay process, but the balancing $\left\{\left(t-t_{1}\right)^{m}\right\}$ initiated by the decay at $t_{1}$ generates a new macroscopic state satisfying the initial conditions and thus initiates a new contribution to the relaxation, giving the composite relaxation rate at time $t$ shown in equation (20). The value of $M^{\prime}\left(t-t_{1}\right)$ is evaluated from

$$
\frac{d\left\{M^{\prime}\left(t_{2}-t_{1}\right)\right\}}{d\left(t_{2}-t_{1}\right)}=-\omega_{p}\left(t_{2}-t_{1}\right)^{m} t_{1}^{-m} M^{\prime}\left(t_{2}-t_{1}\right)
$$

giving

$$
\ln \left[M^{\prime}\left(t_{8}\right) / M_{(0)}^{\prime}\right]=-\omega_{\mathrm{p}} \int_{0}^{t_{0}}\left(t_{3}-t_{1}\right)^{m} t_{1}^{-m} \mathrm{~d}\left(t_{8}-t_{3}\right)
$$

and hence, using equation (20), and normalising to unity,

$$
M^{\prime}\left(t-t_{1}\right)=M_{(0)}^{\prime} \exp \left\{-\omega_{\mathrm{p}}\left(t-t_{1}\right)\right\}
$$

The variable in equation (21) is the time span, $\left(t_{3}-t_{1}\right)$, during which the relaxation proceeds uninterrupted as opposed to the actual time, $t$, at which measurements are made.

The initial deviation from equilibrium, $M_{(0)}^{\prime}$, arises from the removal of a perturbation which alters $B$, for example an external electric field which makes a contribution $F d$ to $B$ where $d$ is the local $z$ component of the dipole moment, and is given by

$$
M_{(0)}^{\prime}=\tanh \left(\frac{B+F d+k T_{c} \lambda I_{(0)}^{\prime}}{k T}\right)-M_{e}
$$


That is, F rotates the macroscopic dipole towards or away from the fixid internal fiold direction.

The rate constant $\omega_{p}$ is the maximum probability that a therrnally activated process leads to a transition of a dipole bitwien atternate minima. The activated factor is the probability for a thermal process of suflicient energy to surmount the burrier, and the pre-exponential factor is the quantum mechanical transition rate at the barrier peak.

A secord independent relaxation process, that of local tunnelling, may also occur. Each tunnelling event takes place in a time of approximately $\nu_{0}^{-1}$ and flips a dipole from one minimum to the other. A transient configuration is thus created in each well in a manner similar to that generated by flip-fiops, and which decays by a time power law with a different exponent,

$$
\cos (n \pi / 2) \cdot(t \zeta)^{-n}
$$

the range of frequencies, $\zeta$, in the slow system being from zero up to $\nu_{0}$, or the maximum value in the system, whichever is lower. This behaviour describes the tunnelling relaxation of a deviation in $M$, and in this case there is no balancing time behaviour. The magnitude of $n$ is proportional to the amount of configuration change introduced by exciting a single dipole, as a fraction of the maximum possible change, and is therefore the degree of cooperation of dipole tunnelling:

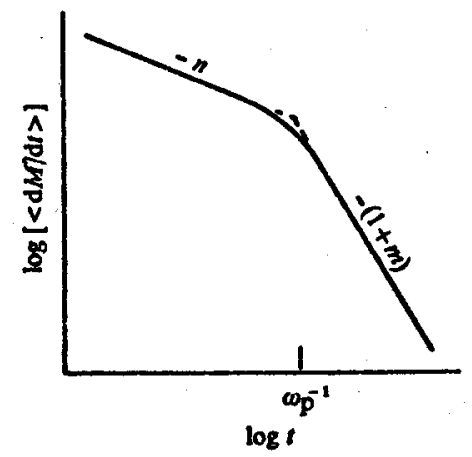

Kig. 3 A log-log plot of the decay current as a function of time. The power law limiting behaviour regions can be clearly scen.

This cooperative tunnelling relaxation process competes independently with the thermally activated relaxation, equation (23), and takes place on the same time scale. Therefore, at a time $t-t_{1}$ after the relaxation has been initiated at $t_{1}, M^{\prime}$ has relaxed to

$$
M^{\prime}\left(t-t_{1}\right)=M_{(0)}^{\prime} \cos (n \pi / 2) \cdot\left[\zeta\left(t-t_{1}\right)\right]^{-n} \exp \left\{-\omega_{p}\left(t-t_{1}\right)\right\}
$$

The value of the relaxation current observed at time $t$ is that given in equation (20) with $M^{\prime}\left(t-t_{1}\right)$ given in equation (26) and is

$$
\begin{aligned}
& \left\langle\frac{\Delta M}{d t}\right\rangle=\frac{\omega_{D} \cos \left(\frac{n \pi}{2}\right) \zeta^{-n} \int_{0}^{t}\left(t-t_{1}\right)^{m} t_{1}^{-m} M_{(0)}^{\prime}\left(t-t_{1}\right)^{-n} e^{-\omega_{p}\left(t-t_{1}\right)} d t_{1}}{\int_{0}^{t}\left(t-t_{1}\right)^{m} t_{1}^{-m} d t_{1}} \\
& \propto-\omega_{p} \cos \left(\frac{n \pi}{2}\right) \zeta^{-n} M_{(0)}^{\prime} e^{-\omega_{p}^{\prime}} . t^{-n_{1}} F_{1}\left(1-m ; 2-n ; \omega_{D} t\right)
\end{aligned}
$$

Whefe $\left(F,(; i)\right.$ is the confluent hypergeometric function ${ }^{24}$. 1. 1 ustion 27 ) describes a complex situation. An initial deviation dcways llirough two independent processes. One is an internal ted issiment, and is described by the $t^{-n}$ behaviour. The other is is thermal decay process in which the rate constant fluctuates about an average valuc. These fluctuations are the result of a second microscopic interaction. The composite rate observed at time $t$, therefore, has to be averaged over the fluctuations. A linear Ising model calculation of configuration correlation functions ${ }^{25}$ has revealed sonie of the features of the above expression.

\section{Frequency-dependent susceptibility}

To obtain the linear frequency-dependent susceptibility a form of $\left(\mathrm{d} M^{\prime} / \mathrm{d} t\right\rangle$, equation (26), requires to be determined in which the initial deviation from equilibrium is linear in field strength. Expanding equation (24) gives

$$
M_{(0)}^{\prime}=\frac{F d}{k T}\left(1-M_{\varepsilon}^{2}\right)\left\{1-\left(1-M_{e}^{2}\right) T_{\mathrm{c}} / T\right\}^{-1}
$$

The frequency dependence of the susceptibility is given by a standard transformation of equation (26). The time development of equation (26) is shown in Fig. 3. At short times the confluent hypergeometric function has a limiting value of unity, as has the exponential term, and hence

$$
\left\langle\frac{\mathrm{d} M}{\mathrm{~d} t}\right\rangle=J \propto\left(\omega_{\mathrm{p}} t\right)^{-n}
$$

where $J$ is the decay current. At infinite time the asymptotic form of the hypergeometric term is proportional to $\exp \left(+\omega_{p} t\right) .\left(\omega_{p} t\right)^{n-m-1}$ and the equivalent current is given by

$$
\left(\omega_{\mathrm{p}} t\right)^{-(1+m)}
$$

In the limited region around $t \approx \omega_{p}^{-1}$ the decay is dominated by the exponential term. The Laplace transform of equation (26) is $^{26}$, in normalised form,

$$
\chi(\omega) \propto \frac{\omega_{p}^{1-n}}{\left(\omega_{p}+i \omega\right)^{1-n}} \cdot{ }_{2} F_{1}\left(1-n, 1-m ; 2-n ; \frac{\omega_{p}}{\left(\omega_{p}+i \omega\right)}\right)
$$

in which ${ }_{2} F_{1}(, ; ;)$ is the gaussian hypergeometric function ${ }^{26}$. Equation (31) has the simple asymptotic behaviour that at frequencies greater than $\omega_{p}$ both the real and imaginary parts of the complex susceptibility are proportional to $\omega^{-(1-n)}$, in agreement with equations (1) and (2). At frequencies less than $\omega_{p}$ the imaginary part of the susceptibility is proportional to $\omega^{\mathrm{m}}$ and the real part is given by $X^{\prime}(\omega-0)-A X^{\prime \prime}(-)$ where $A$ is a constant, in agreement with equation (1). The curvature parameter $s$ of equation (1) is found to be a single-valued function of $m$ and $n$.

The particular value of $m$ equal to unity is of interest as it can arise either when there is perfect correlation in the flip-flop processes, or when measurements are made at sufficiently high frequencies that the slow responders cannot give rise to the fluctuation process. Both forms have been observed experimentally'.

\section{Discussion}

The basic requirements for the present model is the presence of a set of two-level systems in which the frequency difference ranges from zero upwards, and in which the number density is effectively constant. The existence of these states has been demonstrated experimentally in glasses ${ }^{19}$ and theoretically estrublished in other materiais ${ }^{6}$; from this the high frequency be'naviour follows. It should be pointed out that most dielectric susceptibility measurenients are made close to a phase transition ${ }^{27.28}$ where a cooperative system of structural changes with at least two local potentials must exist. The local two-level system considered here can be regarded as describing the structural changes involved in a phase transition. The processes described here are the microscopic reality behind Jonscher's 'screened hopping model ${ }^{29}$. The exponents $n$ and $m$ have bcen determined as follows; $m$ is the degree of structural adjustment required for the average flip-flop process. It is therefore a 152 orrelation of these processes in the ground state. $n$ Is the degree 
of structural adjustmenc requircu for the average spin flip (spin raised or lowered). It is thus a correlation factor for the dynamic restorative tunnelling events.

It is expected that mechanical strain, nuclear magnetic resosiance $T_{1}$ measurements ${ }^{31}$, magnetic susceptilility and the molecular dynamics of plastic crystals will show similar bchaviour ${ }^{28}$. In particular ultrasonic absorption nleasurements in which the pseudo-spins respond to variations in $B$ produced by acoustic vibritions show a similar response ${ }^{31}$.

Finally we point out that a non-exponential decay behaviour is a theoretical necessity in all systems which do not have an infinite range of energy in their deccmposed state ${ }^{32}$, for example which may recombine. The required behavjour has to be faster

1. Hill, R. M. Nature 275,96 (1978).

2. Jonscher, A. X. Co'inid Polymier Sci, 253, 231 (1975)

3. Jonscher, A. K. Ph;s. stat. sol. 83, 585 (1977); 84, 154 (1977).

4. Jonscher, A. X. Nartive 267,673 (1977).

5. Jonscher, A. K. Phyries of Thin Films (ed. Francombe, At. H.) (Acadeusic, New Yorx, in the press).

6. Ngai, K. L., Jonscher, A. K. \& White, C. T. Nature, 277, 185 (1979)

7. Anderson, P. W., Haiperin, B. I. \& Varma, C. Phil. Mag. 25, 1 (1972)

8. Pbillips, W. A. J. Low. Temp. Phys. 7, 351 (1972).

9. Hopfield, J. J. Commun. Sol. State. Phys. 11, 40 (1969).

10. Havfield, J. J. Commun. Sol. State. Phys. 11, 40 (1969).

11. Clarie, M. D. Craic. D. P. \& Dissado, L. A. Molec. Cyst. Liquid Cryst. 44, 309 (1978).

12. Toyozawa, Y. J. Luminescence 1, 2732 (1970).
13. Duke, C. B. \& Mahan. G. D. Phys. Rev. 139, A1965 (1965).

14. Goldberger, M. L. \& Wasson, X. M. Collision Theory (Wiley, New York, 1964).

15. Fetrell, R. A. Phys. Rev. 136, 399 (1969).

16. Yuval, G. \& Anderson, P. W. Phys. Rev. B1, 1522 (1970)

17. Abramowitz, M. \& Stequn, I. A. Handbook of Mathematical Functions, (Dover, New York, 1965). than exponential at short times and slower than exponential at long times. The transitional behaviour between these rcgions is close to exponential in form, as it is here. Usually the availabl: experimental time region is such that only minor deviations from a: cxponentia! behaviour can be ohsived. l'ecause dielectris slisceptibility is observable over wide ranges of irequency and amplitude, and is amenable to temperature scaling, it provides a unique opportunity to study the details of the non-exponential decay and the microscopic mechanisms involved.

We thank the SRC for an assistantship for L.A.D., and A. K. Jonscher for his continued assistance and encouragement.

Received 26 January; accepted 10 May 1979.

18. Hunklinger, S. \& Arnold, W. Phys. Acoustics 12, 195 (1976).

19. Jofirin. J. \& Levelut, A. J. Phys. (Paris) 36, 11 (1975).

20. Jackle, J., Piche, L., Arnold, W. \& Hunklinger, S. J. Non-Cryst. Sol. 20, 365 (1976).

21. Parry Jones. G. Transfer and Storage of Energy by Molecwies Vol. 4, 471 (Wiley. London. 1974).

22. Rubenstein, M. Reising. H. A., Reinecke, T. L. \& Ngai, K. L. Phys, Rev. Len. 34, 1444 (1975).

23. Brereton, M. G. Davies, G. R. Polymer 18, 764 (1977).

24. Slater, L. J. Confuent Hyperzeomerric Functions (Cambridge University Press, 1960).

24. Slater, L. J. Confuent Hyperzeometric Funcion

25. Bozdemir, S. thesis, Univ. London (1979).

26. Slater, L. .. Generalised Hypergeometric Functions (Canbridge Unikertiny Press, 1966). MeCrum, N. G., Read, B. E. R Wh Solids (Wiley, London, 1967)

28. Bondi, A. Physical Properies of Molecular Crystals, Liquids and Gasses (Wiley, New York, 1968)

29. Jonscher, A. X. Nature 253, 717 (1975).

30. Kluver, W. \& Roland, W. Prog. Colloid Polymer. Sci. 64, 235 (1973).

31. Eden, D., Garland, C. W. \& Williamson, R. C. J. chem. Prys. 58, 1861 (1973).

32. Fonda, L., Ghirardi, G. C \& Rimini, A. Rep. Prog. Phys. 41, 587 (1978)

\title{
Thermal aspects of komatiite generation and greenstone belt models
}

\author{
B. L. Weaver \& J. Tarney
}

Department of Geological Sciences, University of Birmingham, UK

Thermal modelling suggests that the problems posed by the nigh liquid temperatures $\left(\sim 1,650^{\circ} \mathrm{C}\right)$ of peridotitic lavas in Archuean greenstone belts, and the implied high degree of mantle melting $(\sim 70 \%)$, are significantly reduced by considering uprise of a more refractory mantle diapir hav. ing an inherent density contrast with the surrounding mantle, and in a tectonic environrent analogous to a marginal basin.

LAVAS of komatitic composition ${ }^{1.2}$, representing very high magnesian liquids with up to $33 \% . \mathrm{MgO}$, are a common and distinctive magma type in Archaean greenstone belts, although comparable high magnesian liquids become increasingly rare in younger post-Archaean volcanic provinces. They occur most frequently in the lower parts of greenstone volcano-sedimentery sequences, where there may be several cycles of ultramaficmafic lavas. Although crystal fractionation has been demonstrated in some ultramafic-mafic lavas ${ }^{3}$, the presence of spinifex quench textures ${ }^{4}$ indicates that in most cases the high- $\mathrm{MgO}$ character is primary and not due to olivine accumulation. Deriving such highly magnesian liquids by mantle fusion poses severe thermal problems.

Experimental studies ${ }^{3}$ have shown that the high liquidus temperatures of peridotitic komatiite $\left(-1,650^{\circ}\right.$ at 1 atmn) would require $-70 \%$ partial melting of mantle pyiolite. Similar 165 tint experiments on mantle nodules have also demons: 1 that high degrees of melting would be required to produce periodotitic komatiite liquids. Modelling of the thernal evolution of ascending pyrolite diapirs ${ }^{7.8}$ indicates that attainment of this high degree of partial melting would necessitate initiation of mantle diapirs from depths in excess of $300 \mathrm{~km}$. This somewhat extreme requirement has led to suggestions ${ }^{8}$ that the mantle source regions may have been enriched in radioactive heatproducing elements.

Recent detailed geochemical studies of Archaean greenstone volcanic sequences in Canada, Australia, Rhodesia, Soult Africa and Finiand $d^{9-12}$ have shown, however, that many peridotitic komatiite lavas not only have low trace element abundances, as may be expected with high degrees of mantle melting. but also have light rare-earth depleted rare-earth clement patterns and low incompatible element abundances (Fig. 1). -These features have been taken as indicating that such peridotitic komatiites are derived from a 'depleted' mantie source ${ }^{12}$ similar to that for modern mid-ocean ridge basalts, and are most unlikely to have been enriched in $U$, Th, $K$ and $R b$. Other peridotitic komatiites may have essentially undepleted or even slightly enriched geochemical characteristics ${ }^{11}$, but these are not a dominant group. The geochemical studies have also demonstrated that associated tholeiitic basalts in greenstone sequences have fiat chrondritic rare-earth patterns (Fig. 1), higher levels of incompatible elements and essentially 'undepleted' incompatible elemeut ratios. They do not seem to be consanguinous with the depleted komatiitic lavas but have been derived from a different mantle source. Inhomogeneity in the Archaean mantle 


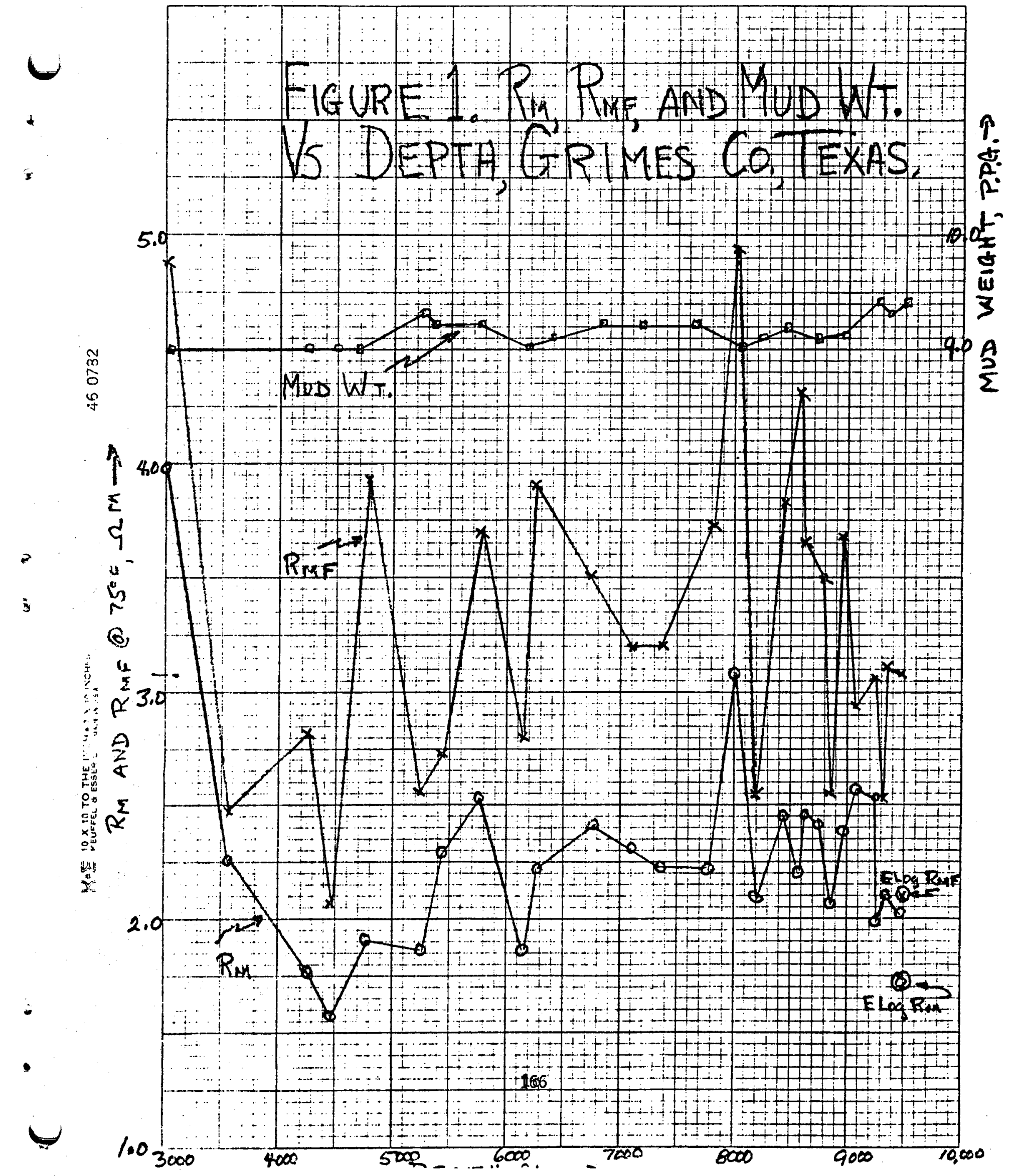




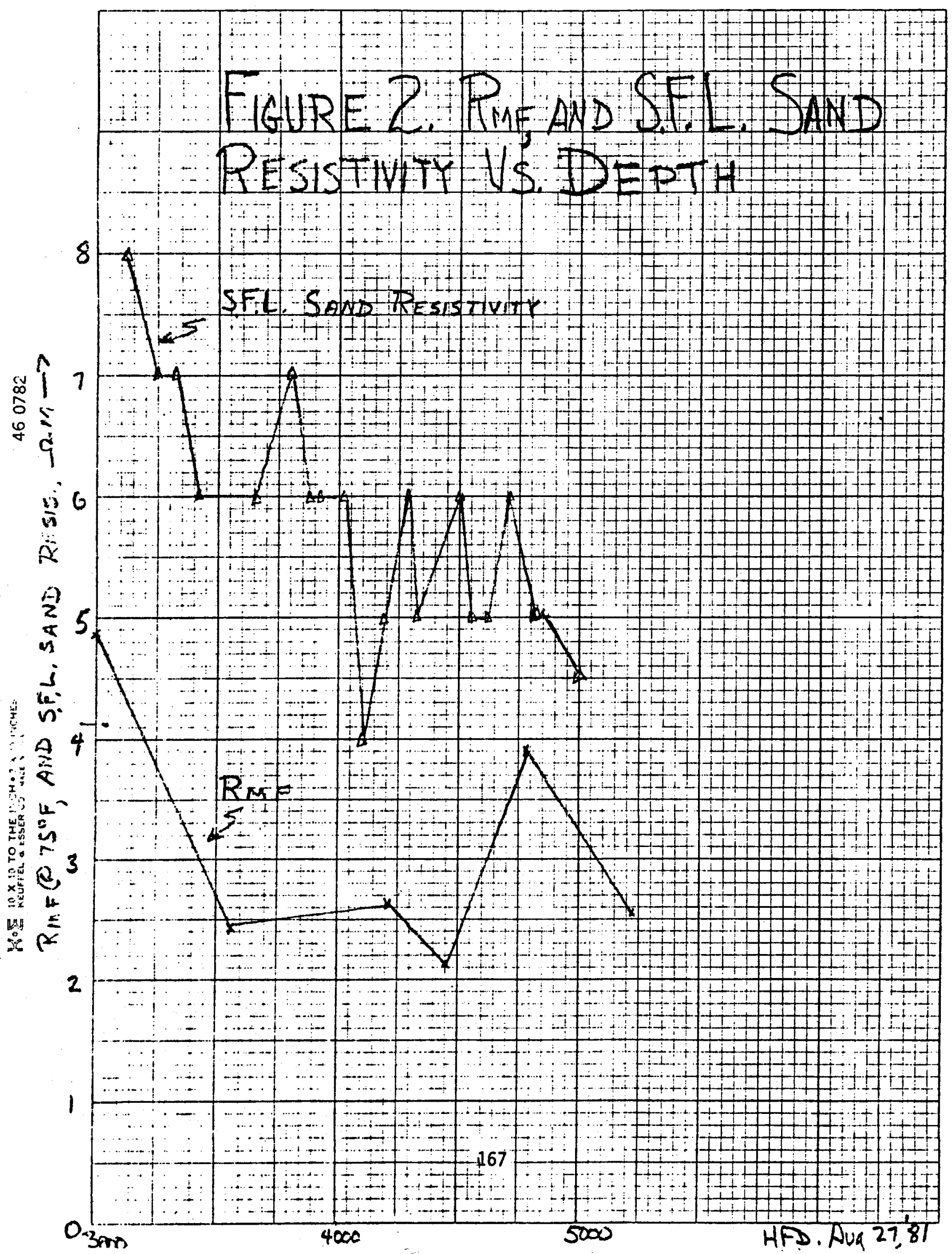

